Organizadores

Fernando Icaro Jorge Cunha

Leonice Aparecida de Fátima Alves Pereira Mourad

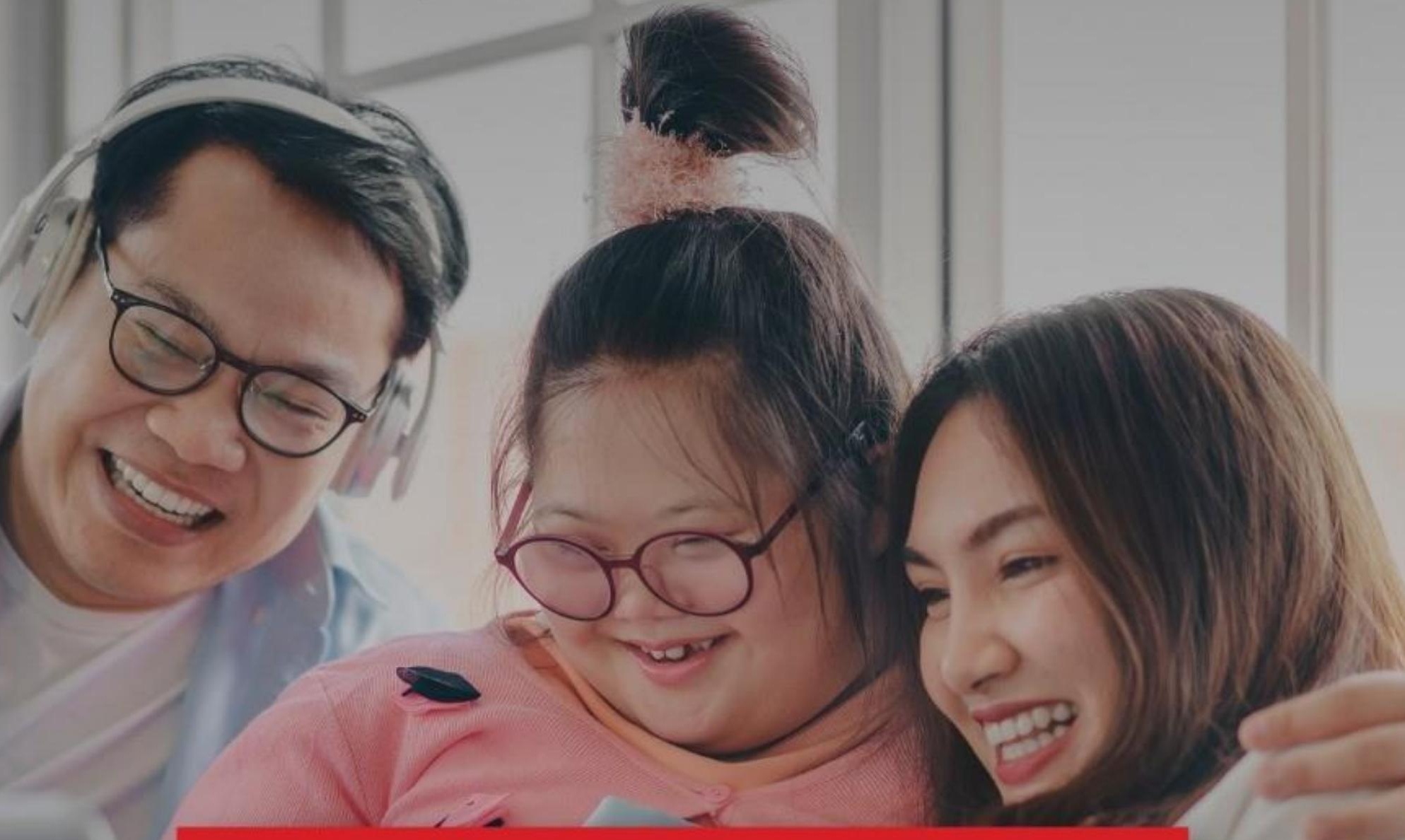

\title{
EDUCAÇÃO ESPECIAL INCLUSIVA: díáloģos da edurcação BÁSICA AO ENSINO SUPERIOR
}

$1{ }^{\circ}$ Ediçăto

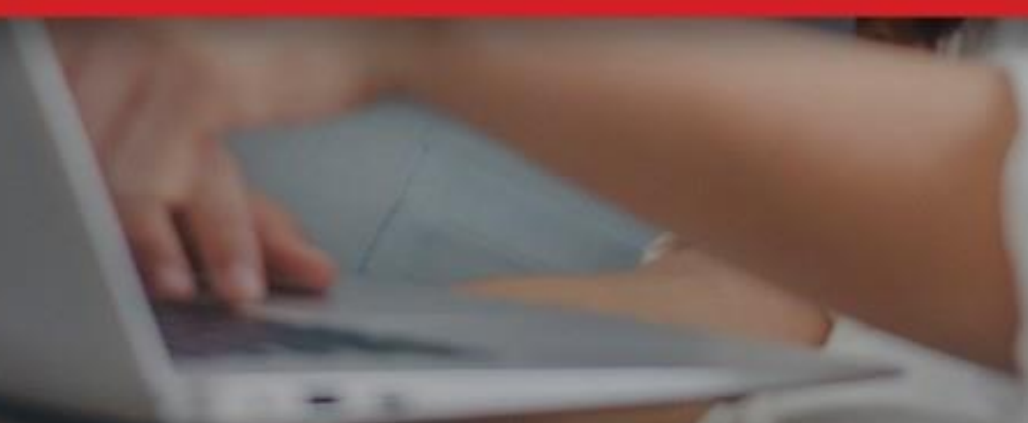

Curitiba

EDITORA REFLEXÃO ACADÊMICA

2021 


\author{
Organizadores \\ Fernando Icaro Jorge Cunha \\ Leonice Aparecida de Fátima Alves Pereira Mourad
}

\title{
Educação especial inclusiva: diálogos da educação básica ao ensino superior
}

$1^{\circ}$ Edição

Curitiba

2021 
Copyright (C) Editora Reflexão Acadêmica

Copyright do Texto (C) 2021 O Autor

Copyright da Edição (C) 2021 Editora Reflexão Acadêmica

Editora-Chefe: Profa. Msc. Barbara Luzia Sartor Bonfim Catapan

Diagramação: Lorena Fernandes Simoni

Edição de Arte: Lorena Fernandes Simoni

Revisão: O Autor

O conteúdo do livro e seus dados em sua forma, correção e confiabilidade são de responsabilidade exclusiva da autora. Permitido o download da obra e o compartilhamento desde que sejam atribuídos créditos a autora, mas sem a possibilidade de alterá-la de nenhuma forma ou utilizá-la para fins comerciais.

\section{Conselho Editorial:}

Prof. Dr. Alasse Oliveira da Silva, Universidade Federal Rural Rural da Amazônia UFRA

Prof. Msc. Mauro Sergio Pinheiro dos Santos de Souza, Instituto Brasileiro de Geografia e Estatística - IBGE

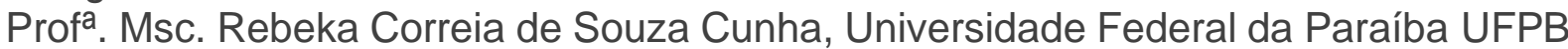
Prof. Msc. Andre Alves Sobreira, Universidade do Estado do Pará- UEPA

Profa ${ }^{\text {. }}$ Dr ${ }^{\mathrm{a}}$.Clara Mariana Gonçalves Lima, Universidade Estadual de Campinas UNICAMP

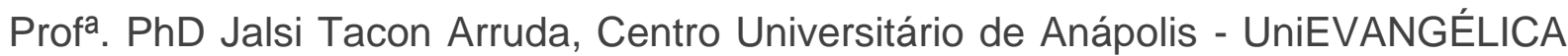
Profa ${ }^{\text {. Dra }}$. Adriana Avanzi Marques Pinto. Universidade Estadual Paulista Júlio de Mesquita Filho-UNESP

Prof. Dr. Francisco Souto de Sousa Júnior, Universidade Federal Rural do Semi-Árido -UFERSA

Prof. Dr. Renan Gustavo Pacheco Soares, Universidade Federal de Pernambuco UFPE 


\begin{tabular}{|l}
\hline Dados Internacionais de Catalogação na Publicação (CIP) \\
\hline C972e $\quad$ Cunha, Fernando Icaro Jorge; Mourad, Leonice Aparecida de \\
Fátima Alves Pereira. \\
Educação Especial Inclusiva: Diálogos da Educação Básica ao \\
Ensino Superior I Fernando Icaro Jorge Cunha; Leonice \\
Aparecida de Fátima Alves Pereira Mourad. Curitiba: Editora \\
Reflexão Acadêmica, 2021. \\
283 p. \\
Formato: PDF \\
Requisitos de sistema: Adobe Acrobat Reader \\
Modo de acesso: World Wide Web \\
Inclui: Bibliografia \\
ISBN: 978-65-995551-1-4 \\
DOI: doi.org/10.51497/reflex.0000069 \\
\\
1. Educação. 2.Inclusão. \\
I. Cunha, Fernando Icaro Jorge. II. Mourad, Leonice \\
Aparecida de Fátima Alves Pereira. III. Título
\end{tabular}

\footnotetext{
Editora Reflexão Acadêmica

Curitiba - Paraná - Brasil

1contato@reflexaoacademica.com.br
} 


\section{ORGANIZADORES}

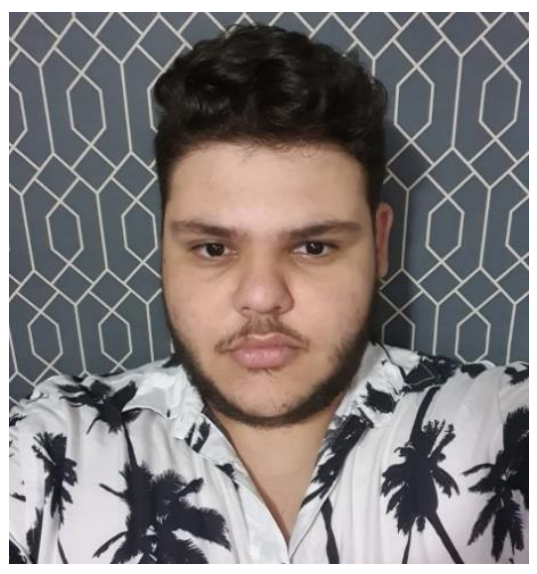

Fernando Icaro Jorge Cunha - Professor formado em magistério em nível médio (Curso Normal) no CIEP 179 Professor Claudio Gama/RJ. Discente de graduação no Curso de Licenciatura em Ciências da Natureza na Universidade Federal do Pampa/Campus Uruguaiana. Atua desenvolvendo projetos de Ensino e Extensão, cursos de formação continuada para profissionais da Educação Básica, bem como, iniciação científica na área da Bioquímica Toxicológica. Atualmente é bolsista CAPES, PRAEC, PASP, PDA e bolsista do programa Santander Graduação, através da seleção de graduandos com excelência em rendimento acadêmico no edital $\mathrm{n}^{\circ}$ 273/2020. Atua desde o primeiro semestre da graduação no Programa Institucional de Bolsas de Iniciação à Docência (PIBID) e ainda bolsista PROEXT, na função de professor/tutor no Curso de Capacitação na modalidade EaD para profissionais da Educação Básica - Educação Ambiental: do pensar global ao agir regional, sob orientação do Pr. Dr. Ailton Jesus Dinardi. Em 2020, atuando novamente na PROEXT através da equipe gestora e executora do curso "O Uso do QRCode como ferramenta para a organização de trilhas urbanas", sob orientação do Pr. Dr. Ailton Jesus Dinardi. Membro do Grupo de Extensão "Pandemia da Solidariedade", orientado pela Prª Drª Daniela Müller, auxiliando os idosos da cidade de Uruguaiana-RS em diversos sentidos, e orientações durante a crise ocasionada pela pandemia do novo coronavírus (Sars-Cov-2). Foi professor/tutor do curso oferecido pela Comissão Institucional de Formação dos Profissionais da Educação Básica - CIFOR/Unipampa intitulado "Subsídios básicos de psicologia da educação para a aprendizagem significativa", sob orientação da Pra ${ }^{a} r^{a}$ - Raquel Ruppenthal. Atualmente desenvolve o projeto intitulado "Processos de Formação e Articulações Didático-Pedagógicas para Professores de Ciências da Natureza" (Edital n 40/2021), desenvolve tal curso que tece um projeto de extensão sobre orientação do Prof. Dr. Ailton Jesus Dinardi. É bolsista do Núcleo de Desenvolvimento Educacional - NuDE/Unipampa, desenvolvendo colaboração na assistência social à discentes que se enquadram nos perfis de ações afirmativas. 


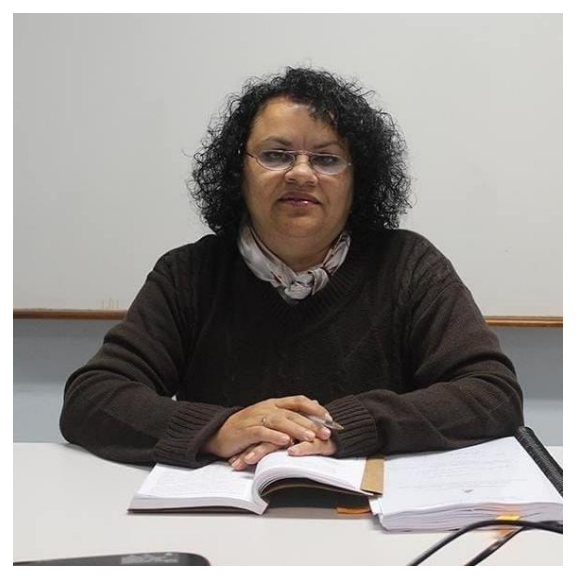

Leonice Aparecida de Fátima Alves Pereira Mourad - Graduada em Bacharel em Direito pela Universidade do Vale do Rio dos Sinos (1990-II), Graduada em Licenciatura em História pela Universidade do Vale do Rio dos Sinos (1999-II) Graduada em Bacharel em Ciências Sociais pela Universidade Luterana do Brasil (2007-II); Graduada em Licenciatura em Geografia pela ULBRA (2017-I), Graduada em Bacharel em Serviço Social pela ULBRA (2018-II), Graduada como Tecnóloga em Agricultura Familiar e Sustentabilidade pela UFSM(2017-2), Graduada em Licenciatura em Educação do Campo pela UFSM(2020-I), Graduada em Licenciatura em Pedagogia pela UNINTER(2019-I), Graduada em Licenciatura em Letras pela UNINTER(2020-II), Graduada em Licenciatura em Filosofia pela UNINTER(2021-I). Tem especialização em Metodologia do Ensino Superior pela Universidade do Vale Rio dos Sinos (1993) e Serviço Social pela UNINTER; Mestre em História da América Latina pela Universidade do Vale do Rio dos Sinos (2002) e Doutorado em História da América Latina pela Universidade do Vale do Rio dos Sinos (2008). Mestre e Doutora em Geografia $(2015,2019)$ pela UFSM e mestranda em Políticas Públicas e Gestão Educacional pela pela UFSM. Atualmente é professora do Departamento de Metodologia da Universidade Federal de Santa Maria, sendo Coordenadora do Mestrado Profissional em Ensino de História. Tem experiência na área de Ciências Sociais, História, Direito, Geografia e Ciências Agrárias Sociais, desenvolvendo atividades de pesquisa e extensão acerca de temáticas agrárias. 


\section{APRESENTAÇÃO}

O livro "Educação Especial Inclusiva: Diálogos da Educação Básica ao Ensino Superior", constitui-se em uma coletânea formada por 20 capítulos, enfatizando a educação básica e superior apresentando algumas possibilidades de inserção no mercado de trabalho. Uma obra de fácil leitura e pedagogicamente fundamentada e estruturada, proporcionando a você leitor compreender aspectos vinculados à inclusão, com um olhar mais sensível e crítico, que expõem questões políticas, sociais e educacionais.

Nos primeiros capítulos, o leitor encontrará temáticas relacionados à trajetória histórica e política da inclusão, questionando as políticas educacionais, sua acessibilidade e a dificuldade de implementação da mesma. Além de refletir sobre uma educação inclusiva e os direitos fundamentais, que na maioria das vezes estão situados apenas em documentos. Cogitando assim, mais empatia e voz àqueles que muitas vezes são invisibilizados frente a uma sociedade padronizada e estereotipada.

Muitas vezes, a visibilidade se dá pela aceitação e reconhecimento daquelas pessoas, que estão mais próximas as pessoas com necessidades especiais (familiares), aumentando a autoestima e sua independência. Para isto ocorrer, existe um longo caminho a ser trilhado, iniciando com a participação e união dos familiares com a escola.

Neste livro, o leitor também irá encontrar reflexões e fundamentos, estes apontam que a educação possibilita à criança desenvolver suas habilidades e competências singulares, respeitando seu ritmo para o aprendizado na construção do conhecimento. O despertar para novos desafios corresponde a diversos procedimentos, planejamentos e métodos de intervenção dos educadores. Os profissionais capacitados, ganham um destaque todo especial, pois farão toda diferença no processo de ensino-aprendizagem destas crianças articulando, importantes mediadores específicos como, pedagogos, psicopedagogos, psicólogos e a neurocientistas, os quais entendem e contribuem cientificamente e metodologicamente para garantir a educação inclusiva, tornando-a mais eficaz e equânime.

Nesta trajetória de superação que toda criança com necessidade especial terá que passar, a dimensão lúdica, abordada na segunda unidade, é um facilitador de práticas pedagógicas e proporciona aos alunos especiais uma ferramenta para sua inclusão e, consequentemente, permanência nas instituições de ensino. A inclusão educacional é parte integrante da construção de uma sociedade que prioriza a acessibilidade, flexibilidade e equidade a fim que possibilitem práticas colaborativas e personalizadas de trabalho em conjunto.

Sem hesitação, devemos destacar que a conscientização sobre o fato das pessoas com necessidades especiais pode e deve ser uma dimensão presente na leitura dessa obra, que traz pontos cruciais para visualizar ações inclusivas. Todos sabemos, que apesar do paradigma inclusivo, até o presente momento, muitos avanços estão por fazer, ainda falta muito para chegarmos à equidade e com respeito mútuo e valorização da diversidade. 
Boa leitura!

Cristiane de Freitas Rodrigues

Fernando Icaro Jorge Cunha 


\section{SUMÁRIO}

CAPÍTULO 01 .1

INCLUSÃO: TRAJETÓRIA HISTÓRICA DA EXCLUSÃO À INCLUSÃO NOS AMBIENTES ESCOLARES

Ediane Kelly Soares Filocreão

Lilian Patricia Soares Filocreão

Fernando Icaro Jorge Cunha

Leonice Aparecida de Fátima Alves Pereira Mourad

Maria José Baltazar de Azambuja

Janete Hickmann

Gabriel Ferraz Martins

DOI: doi.org/10.51497/reflex.0000070

CAPÍTULO 02

DIFICULDADES PARA A EFETIVAÇÃO DA INCLUSÃO NO BRASIL:

SISTEMATIZANDO A REALIDADE EM FUNÇÃO DAS POLÍTICAS PÚBLICAS

Fernando Icaro Jorge Cunha

Gabriel Ferraz Martins

Ediane Kelly Soares Filocreão

Lilian Patricia Soares Filocreão

Maria José Baltar de Azambuja

Luciana Martins Vieira

Rita Freitas Ribeiro Pessano

Joel de Almeida Nunes

Janete Hickmann

DOI: doi.org/10.51497/reflex.0000071

CAPÍTULO 03

O DESAFIO DE INCLUIR E A NECESSIDADE DE INOVAR: UM DIÁLOGO ENTRE AS DEFICIÊNCIAS E OS SUBSÍDIOS PEDAGÓGICOS

Fernando Icaro Jorge Cunha

Maria José Baltar Azambuja

Janete Hickmann

Leonice Aparecida de Fátima Alves Pereira Mourad

Letícia Neutzling Benites

Rejane Marques Alves

DOI: doi.org/10.51497/reflex.0000072

CAPÍTULO 04

A IMPORTÂNCIA DO ATENDIMENTO EDUCACIONAL ESPECIALIZADO (AEE) NO ENSINO REGULAR

Fernando Icaro Jorge Cunha

Maria José Baltar de Azambuja

Adriana da Silva Biavaschi

Cristiane de Freitas Rodrigues

Caroline Pugliero Coelho

Letícia Neutzling Benites 
Luciana Martins Vieira

Janete Hickmann

DOI: doi.org/10.51497/reflex.0000073

CAPÍTULO 05

POSSÍVEIS ÁREAS DE ESTUDO DA INCLUSÃO ESCOLAR: UMA ABORDAGEM INTRODUTÓRIA

Fernando Icaro Jorge Cunha

Luciana Martins Vieira

Maria José Baltar de Azambuja

Janete Mendonça Chrispim Maia

Márcio da Mota Machado Filho

Adriana da Silva Biavaschi

Cristiane Casagrande Denardin

Jean Ramos Boldori

Joel de Almeida Nunes

Janete Hickmann

DOI: doi.org/10.51497/reflex.0000074

CAPÍTULO 06

INCLUSÃO E ENCAMINHAMENTO PARA O MUNDO DO TRABALHO

Fernando Icaro Jorge Cunha

Luciana Martins Vieira

Maria José Baltar de Azambuja

Rejane Marques Alves

Leonice Aparecida de Fátima Alves Pereira Mourad

Janete Hickmann

DOI: doi.org/10.51497/reflex.0000075

CAPÍTULO 07

PRÁTICAS INOVADORAS EM EDUCAÇÃO ESPECIAL E INCLUSIVA

Cristiane de Freitas Rodrigues

Fernando Icaro Jorge Cunha

Luciana Martins Vieira

Maria José Baltar de Azambuja

Rita Freitas Ribeiro Pessano

Cristiane Casagrande Denardin

Jean Ramos Boldori

Márcio da Mota Machado Filho

Osmar Senador Mendonça Júnior

Janete Hickmann

Gabriel Ferraz Martins

DOI: doi.org/10.51497/reflex.0000076

CAPÍTULO 08

103

A FORMAÇÃO DE ESPECIALISTAS EM EDUCAÇÃO ESPECIAL E INCLUSIVA

Fernando Icaro Jorge Cunha

Leonice Aparecida de Fátima Alves Pereira Mourad 
Simone Baltazar Ferras

Janete Hickmann

Adriana da Silva Biavaschi

Maria José Baltar de Azambuja

DOI: doi.org/10.51497/reflex.0000077

CAPÍTULO 09

SALA DE RECURSOS MULTIFUNCIONAIS NO DESENVOLVIMENTO DIDÁTICOPEDAGÓGICO

Fernando Icaro Jorge Cunha

Adriana da Silva Biavaschi

Caroline Pugliero Coelho

Luciana Martins Vieira

Maria José Baltar de Azambuja

Janete Hickmann

Janete Mendonça Chrispim Maia

DOI: doi.org/10.51497/reflex.0000078

CAPÍTULO 10

EDUCAÇÃO ESPECIAL INCLUSIVA NO ENSINO SUPERIOR: ABORDAGENS PROBLEMATIZADORAS

Fernando Icaro Jorge Cunha

Cristiane de Freitas Rodrigues

Cristiane Casagrande Denardin

Márcio da Mota Machado Filho

Felix Roman Munieweg

Jean Ramos Boldori

Janete Mendonça Chrispim Maia

Janete Hickmann

DOI: doi.org/10.51497/reflex.0000079

CAPÍTULO 11 146

PARÂMETROS DE SUMA IMPORTÂNCIA NA EDUCAÇÃO ESPECIAL INCLUSIVA: AS INTER-RELAÇÕES SOCIAIS INFLUENCIAM?

Cristiane de Freitas Rodrigues

Fernando Icaro Jorge Cunha

Janete Mendonça Chrispim Maia

Márcio da Mota Machado Filho

Adriana da Silva Biavaschi

Maria José Baltar de Azambuja

Cristiane Casagrande Denardin

Jean Ramos Boldori

Caroline Pugliero Coelho

Simone Baltazar Ferras

Osmar Senador Mendonça Júnior

Salete Pereira Zanella

Janete Hickmann

DOI: doi.org/10.51497/reflex.0000080 
A IMPORTÂNCIA DA AFETIVIDADE NA INCLUSÃO ESCOLAR

Fernando Icaro Jorge Cunha

Eleonora Leguiçamo Centena Silva

Janine Viven Nunes Quevedo

Suélen de Prá Alves

Karen Krystine Oldani da Silva

Maria José Baltar de Azambuja

Janete Mendonça Chrispim Maia

Salete Pereira Zanella

Janete Hickmann

Liliana Vieira Martins

DOI: doi.org/10.51497/reflex.0000081

CAPÍTULO 13

O PAPEL DA MEDIAÇÃO ESCOLAR INCLUSIVA

Fernando Icaro Jorge Cunha

Eleonora Leguiçamo Centena Silva

Janine Viven Nunes Quevedo

Suélen de Prá Alves

Karen Krystine Oldani da Silva

Maria José Baltar de Azambuja

Renata Pereira Vidal da Silva

Ivana Fontoura Carvalho

Liliana Vieira Martins

Janete Hickmann

DOI: doi.org/10.51497/reflex.0000082

CAPÍTULO 14

A LUTA HISTÓRICA PELA INCLUSÃO ESCOLAR: UM DESAFIO ÁRDUO PELA CONQUISTA DE IGUALDADE E RESPEITO

Maria José Baltar de Azambuja

Fernando Icaro Jorge Cunha

Leonice Aparecida de Fátima Alves Pereira Mourad

Janete Hickmann

Joel de Almeida Nunes

DOI: doi.org/10.51497/reflex.0000083

CAPÍTULO 15

TECNOLOGIAS ASSISTIVAS: POTENCIALIZANDO HABILIDADES

APRESENTADAS POR ESTUDANTES DE EDUCAÇÃO ESPECIAL INCLUSIVA

Fernando Icaro Jorge Cunha

Luciana Martins Vieira

Leonice Aparecida de Fátima Alves Pereira Mourad

Maria José Baltar de Azambuja

Caroline Pugliero Coelho

Janete Hickmann

DOI: doi.org/10.51497/reflex.0000084 
ENSINO DE GEOGRAFIA INCLUSIVO: A LINGUAGEM CARTOGRÁFICA COMO RECURSO DE COMUNICAÇÃO

Tuane Telles Rodrigues

Leonice Aparecida de Fátima Alves Pereira Mourad

DOI: doi.org/10.51497/reflex.0000085

CAPÍTULO 17 234

TECNOLOGIA ASSISTIVA (T.A): ALGUNS APONTAMENTOS

André Haiske

Leonice Aparecida de Fátima Alves Pereira Mourad

Maria Carolina Magalhães Santos

DOI: doi.org/10.51497/reflex.0000086

CAPÍTULO 18

ENSINO DE HISTÓRIA PARA SURDOS: PROPOSTA E DESAFIOS NA

EDUCAÇÃO ESPECIAL

Laionel Mattos da Silva

Leonice Aparecida de Fátima Alves Pereira Mourad

DOI: doi.org/10.51497/reflex.0000087

CAPÍTULO 19

PARADIGMAS EM DISPUTAS: INTEGRAÇÃO E INCLUSÃO NA EDUCAÇÃO ESPECIAL

Airton Volnei Prochnow

André Haiske

Cleber Augusto A'Costa de Lima

Leonice Aparecida de Fátima Alves Pereira Mourad

DOI: doi.org/10.51497/reflex.0000088

CAPÍTULO 20

PSICOPEDAGOGIA E DISTÚRBIOS DA LEITURA E ESCRITA: DISLEXIA,

DISCALCULIA, DISGRAFIA, DISORTOGRAFIA

Airton Volnei Prochnow

André Haiske

Isadora Luiza Francisca Alves Flores

Leonice Aparecida de Fátima Alves Pereira Mourad

DOI: doi.org/10.51497/reflex.0000089 


\section{CAPÍTULO 01}

INCLUSÃO: TRAJETÓRIA HISTÓRICA DA EXCLUSÃO À INCLUSÃO NOS AMBIENTES ESCOLARES

Ediane Kelly Soares Filocreão

Advogada pela Universidade Estácio de Sá

Pedagoga pela Universidade Gama Filho

Perfil: http://lattes.cnpq.br/3871227153186585

E-mail:advsoaresfilocreao@gmail.com

\section{Lilian Patricia Soares Filocreão}

Universidade Federal do Estado do Rio de Janeiro

Perfil: http://lattes.cnpq.br/1950274050044786

E-mail:liliansfilocreao@gmail.com

\section{Fernando Icaro Jorge Cunha}

Universidade Federal do Pampa - Unipampa

Perfil: http://lattes.cnpq.br/149558185211586

E-mail: icaro729@gmail.com

\section{Leonice Aparecida De Fátima Alves Pereira Mourad}

Universidade Federal de Santa Maria - UFSM

Perfil: http://lattes.cnpq.br/7689442989367017

E-mail: profleomourad@gmail.com

\section{Maria José Baltar De Azambuja}

Escola Municipal Especial de ensino Fundamental Lygia Morrone Averbuck

Perfil: http://lattes.cnpq.br/8379431150091984

E-mail:mj.azambuja@bol.com.br

\section{Janete Hickmann}

Rede de Ensino Municipal de São Leopoldo - RS

Perfil: http://lattes.cnpq.br/0461298984464544

E-mail: janete22h@gmail.com

\section{Gabriel Ferraz Martins}

Universidade Federal do Rio de Janeiro - UFRJ

Perfil: http://lattes.cnpq.br/8170278356375873

E-mail: gabrielferrazmtrs@gmail.com

Resumo: Neste artigo se considera o direito à Educação como uma das responsabilidades basilares de uma nação, devendo-se, portanto, tomá-la como um direito de todos os indivíduos. Sendo um dever de toda a sociedade buscar viabilizar o acesso a esse direito por diferentes segmentos e grupos. Considerando esse aspecto, a escola se mostra como um palco privilegiado da complexidade social, pois abarca dentro de si, uma multiplicidade de ideias, realidades e contextos históricosociais presentes nas vidas de profissionais da educação e dos alunos. Assim, este 
artigo busca esboçar um breve panorama das práticas educativas inclusivas no Brasil, mediante uma análise histórica de suas trajetórias, desafios e métodos que foram e são empreendidos nos ambientes educacionais do país. O estudo também visa propor medidas que busquem garantir o pleno acesso a um direito fundamental pelos indivíduos que compõem a sociedade.

Palavras-chave: Educação; História; Inclusão; Sociedade. 


\section{INTRODUÇÃO}

A prática de uma educação mais inclusiva passou por uma série de mudanças na história da sociedade brasileira. Tal fato se deve pela própria educação, que nunca foi um elemento acessível a todos os indivíduos, desde os jesuítas que detinham a influência do ensino das elites no período colonial, até a época atual, em que o ensino é mais democratizado, porém ainda apresenta uma série de problemas estruturais, principalmente na educação pública, que se contrasta com o ensino privado, que atende uma parcela privilegiada da população do país.

A sociedade vive um momento de amplo debate, trazendo à tona as reivindicações e demandas das denominadas minorias sociais, há muito tempo silenciadas e negligenciadas em seus direitos, por governos e políticas públicas que empreendiam medidas tímidas de transformações de suas realidades, impossibilitando as suas atuações como cidadãos ativos.

Devido à composição social por uma multiplicidade de indivíduos, todos os quais inseridos em contextos histórico-culturais totalmente diversificados, devendo ter suas dignidades como pessoas humanas respeitadas, o direito à educação é um dos mais significativos e representativos de um país que busca o bem-estar dos seus cidadãos, como bem preceitua a Carta Magna de 1988.

Nesse sentido, entre vários grupos historicamente invisibilizados pelo poder público, e os indivíduos com deficiência se inserem em um contexto mais complexo, com medidas legais ainda muito tardias em serem implementadas, além do preconceito social, formações e capacitações profissionais ainda tímidas no campo do ensino, e falta de estrutura nos ambientes escolares a fim de atenderem de forma mais eficiente e digna tal parcela da sociedade.

Abordaremos um breve panorama histórico das medidas legislativas e metodológicas que buscaram empreender práticas educacionais mais inclusivas, no Brasil e no mundo, principalmente a partir do século XX, além dos vários desafios em implementar mecanismos efetivos de mudanças nos sistemas de ensino. 


\section{MEDIDAS DE INCLUSÃO EDUCACIONAL NO MUNDO}

Os indivíduos com deficiência têm um histórico de exclusão e preconceito cujas origens podem ser identificadas na Antiguidade, se estendendo até os dias atuais. Em termos históricos, o caminho da inclusão começou na exclusão, que em sua acepção mais primitiva, significava "eliminar", "matar" ou "abandonar". Assim é que, na Roma e Grécia antigas, crianças nascidas com alguma deficiência eram abandonadas à própria sorte em locais ermos ou então sacrificadas, uma vez que eram consideradas como uma maldição para a sociedade.

Através de uma série de mudanças políticas, econômicas e culturais, tal quadro começou a se reverter e teve início o processo orgânico da segregação, em que a exclusão da vida em sociedade pareceu uma saída menos cruel que a morte ou o abandono.

Desenvolveu-se então 0 atendimento às pessoas com deficiência em instituições segregadas, que se institucionalizam no século $X I X$ e, no século $X X$, surgem escolas e classes especiais dentro das instituições públicas para atender tal perfil de alunos (CORCINI, CASAGRANDE, 2016, p.4).

Em 1948, com a Declaração Universal dos Direitos Humanos e o reconhecimento da dignidade humana, desenrola-se o processo de integração, que significou a aceitação da ideia de que todos podem estar juntos nos espaços sociais. Todavia, não se promovem adequações nos meios sociais no sentido de adaptar os espaços para essas pessoas: a preocupação reside basicamente em adaptar as pessoas com deficiência à sociedade e não o contrário (SASSAKI, 2010).

Após a Segunda Guerra Mundial, houve um aumento no número de deficientes, muitos ex-combatentes, sendo necessário criar mecanismos que os inserissem na sociedade. Estados Unidos, Canadá e países europeus iniciaram uma série de propostas visando atender às necessidades das pessoas com deficiência.

A partir dos anos 70, devido a uma multiplicidade de movimentos sociais e civis de segmentos subalternizados, reivindicando os seus direitos, o debate sobre a plena inserção dos indivíduos com deficiência ganha mais espaço nas políticas públicas dos governos ocidentais. É quando se desenrola o processo de inclusão, onde todos os indivíduos são convidados a permanecer juntos e são respeitados e convidados a participar ativamente da sociedade. 
Em meados do século XX, ocorre uma série de medidas internacionais visando políticas públicas que tratavam com maior seriedade a inserção social das pessoas com deficiência, e ressaltavam uma Educação Inclusiva, algo que influenciou posteriormente várias medidas governamentais adotadas no Brasil:

- Declaração dos Direitos das Pessoas Deficientes (1975);

- Conferência Mundial de Necessidades Educativas Especiais: Acesso e Qualidade (1994);

- Convenção Interamericana para a Eliminação de Todas as Formas de Discriminação contra as Pessoas Portadoras de Deficiência (1999);

- A Unesco e a Educação na América Latina e Caribe (1987);

- Educação para Todos: o compromisso de Dakar (2000);

- A Unesco no Brasil: consolidando compromissos (2004).

Tais medidas se mostraram como possibilidades para levar uma educação e socialização aos alunos com deficiência, visto que é uma das bases para que os indivíduos construam as suas identidades, e sejam vistos de forma atuante e integrada de fato ao meio em que vivem.

Tem-se a Declaração de Salamanca (1994) como marco e início da caminhada para a Educação Inclusiva. A inclusão é um processo educacional através do qual todos os alunos, incluído, com deficiência, devem ser educados juntos, com o apoio necessário, na idade adequada e em escola de ensino regular. (ROGALSKI, 2010, p. $3)$.

Tais políticas internacionais contribuíram para tornar a Educação Especial em uma área fundamental para a integração de todos os indivíduos na sociedade, e também serviram como parâmetros para uma atuação mais ativa dos governos em diversos países a respeito das pessoas com deficiência.

Logo, a partir da década de 1990, o movimento educacional internacional pela inclusão, que preconizava que todas as pessoas deveriam estar inseridas nos mesmos espaços e tempos escolares, passou a integrar a pauta obrigatória na escola no Brasil, enfatizando-se especialmente o tema sobre as mais eficientes formas de atendimento educacional especializado e sobre a escolarização dos alunos públicoalvo da Educação Especial no sistema regular de ensino. Com efeito, passa-se a discutir a garantia do direito à Educação das pessoas com deficiência, transtorno global do desenvolvimento e com altas habilidades/superdotação, segundo os marcos 
legais, políticos e pedagógicos promulgados por organismos internacionais, como a ONU. (BARBOSA, FIALHO, MACHADO, 2018, p.7).

Atualmente, várias medidas internacionais, associadas aos Direitos Humanos, fazem com que os países busquem acordos para beneficiar as pessoas com deficiência, seja no âmbito educacional, ou no âmbito do mercado de trabalho.

\section{EDUCAÇÃO E INCLUSÃO NO BRASIL}

O processo educacional no Brasil passou por uma série de transformações e múltiplas influências políticas, culturais e econômicas, que contribuíram para tornar o ensino um dos aspectos mais complexos de nossa sociedade.

No período colonial, a educação em nosso território, sob o controle dos jesuítas, não era acessível a todos, apenas indivíduos do gênero masculino - e pertencentes às elites - tinham a oportunidade de estudar e complementavam sua instrução em Portugal.

Durante o início do século XIX, com a chegada da Corte portuguesa ao país, que trouxe toda a sua organização política e cultural, era necessário criar, na nova sede do Império Português, uma estrutura que remetesse à europeia, surgindo posteriormente, colégios, liceus, academias militares e de Medicina, possibilitando uma base educacional aos filhos das elites portuguesas e locais. O perfil dos alunos correspondia aos segmentos pertencentes às oligarquias rurais, grandes latifundiários, que mantinham a política agrária exportadora e com mão de obra escravizada.

No período imperial, houve uma diversificação da clientela que buscava as escolas e liceus provinciais, não apenas indivíduos pertencentes às elites agrárias, mas outros grupos pertencentes às camadas urbanas, e que viam na educação, a possibilidade de ascensão social, almejando para seus descendentes os títulos de Doutor e Bacharel, algo que ocasionaria um prestígio social quase equivalente ao de proprietário de terras.

A transformação que esses colégios sofreram no decorrer do século XIX, no sentido de se tornarem meros cursos preparatórios para o ensino superior, foi uma decorrência da pressão exercida pela classe dominante, a fim de acelerar o preparo de seus filhos e interligá-los no rol dos homens cultos. (...) Aos poucos, tanto liceus 
provinciais quanto colégios particulares foram-se convertendo em meros cursinhos preparatórios para os exames de admissão ao ensino superior existente. Até o Colégio Pedro II, criado na corte e único mantido pelo Governo Central para servir de modelo, não pôde escapar à pressão. (ROMANELLI, 2019, p.41).

Os colégios secundários da época tiveram que se adaptar às pressões das camadas sociais dominantes e proporcionar mudanças em suas estruturas e metodologias. O período oitocentista no Brasil é influenciado pelos valores burgueses da época, como a busca pelo prestígio, lucro e também de uma sólida instrução para os herdeiros de grandes fortunas.

Com a crescente urbanização, e o processo de industrialização ocorrido no decorrer do século XIX, surge uma sociedade com maior poder de consumo, principalmente na Europa, ocorrendo pressões no sentido de expandir a escolarização, pois os moldes aristocráticos e seletivos passaram a ser questionados, sendo a formação de cidadãos qualificados e bem instruídos vista como um caminho para a modernização e enriquecimento do país.

No decorrer do período, assim como ocorria na Europa, no Brasil também havia a necessidade de tratar as pessoas com deficiências em locais especializados. Assim, várias medidas políticas e culturais foram criadas a fim de "tratá-los" e isolá-los em locais mais adequados:

No período de 1854 a 1956, caracterizado pela forma isolada de atendimento escolar a pessoas deficientes, foram criados: o Imperial Instituto dos Meninos Cegos, por D. Pedro II, na cidade do Rio de Janeiro, em 12 de setembro de 1854 e que mudou de nome, em 1890, para Instituto Nacional dos Cegos e, em 1891, para Instituto Benjamin Constant (IBC); o Imperial Instituto dos Surdos- Mudos, por D. Pedro II, na cidade do Rio de Janeiro, em 26 de setembro de 1857 passou a ser denominado, em 1957, de Instituto Nacional de Educação de Surdos (INES). E, em 1874, foi iniciado atendimento médicopedagógico a crianças deficientes mentais no Hospital Estadual de Salvador, atual Hospital Juliano Moreira, na Bahia. Havia, portanto, a preocupação com a educação de três segmentos da educação especial: surdos, cegos e deficientes mentais. (OLIVEIRA, 2017, p.39).

Já no final do século XIX e início do século XX, durante o período republicano, ainda permanecia uma grande defasagem educacional no Brasil, tanto para a população em geral, como para os indivíduos com deficiência. A maioria da população era pertencente aos segmentos subalternos, analfabeta, afrodescendente e miscigenada, perfil historicamente excluído da educação escolar, uma herança cultural de nosso passado escravista e oligárquico, tendo somente nas décadas 
seguintes, suas demandas e carências assistidas por política públicas de governos que se seguiram em nossa história.

Indivíduos com algum tipo de deficiência física ou neurológica, sempre foram discriminados, isolados, segregados, sacrificados e negligenciados ao longo da história. No próprio seio familiar havia silenciamento, e mesmo aprisionamento de tais indivíduos, e a exposição dos mesmos denotava uma falha, que deveria ser obstaculizada do restante da sociedade.

A partir da década de 30, o governo brasileiro passou a apoiar tecnicamente entidades filantrópicas que se dedicavam ao acolhimento de alunos com deficiência, muitas vezes espelhados em iniciativas estrangeiras - um exemplo foi a criação da APAE (Associações dos Pais e Amigos dos Excepcionais) em 1954.

Outros fatos históricos têm a ver com as guerras mundiais, que servem como elementos de mudanças substanciais na realidade da educação. Após a Segunda Guerra Mundial, surgem medidas mais ativas para atender indivíduos com deficiência, devido ao grande número de lesionados, além de demandas econômicas, que geraram uma pressão pela ampliação do ensino e também pelo aperfeiçoamento técnico dos indivíduos, como mão de obra qualificada para alimentar o mercado de trabalho e a economia.

O Brasil sofre a influência de tais avanços e o sistema educacional se volta a práticas pedagógicas mais inclusivas; no que diz respeito à Educação Especial, outro fenômeno de grande impacto foram as mudanças sociais e culturais da década de 70 , que buscaram dar voz a grupos e segmentos silenciados na sociedade, o que leva os entes federais, municipais e estaduais a direcionarem sua atenção às pessoas com deficiência

Notamos um processo longo de viabilidade de medidas na Educação Especial. Nos anos 70, surgem instituições públicas e privadas, legislações e órgãos normativos federais e estaduais para atender a essas "classes especiais".

A partir da redemocratização, na década de 80 , o Brasil passou a ter um olhar mais atento às demandas da Educação Especial, e à integração dos alunos com deficiência nas escolas, pautadas por normas e medidas mais eficazes. Dentre as várias legislações que foram criadas no Brasil, a respeito de uma educação mais inclusiva, podemos enumerar algumas delas: 
Lei № 4.024/ 61: Lei de Diretrizes e Bases da Educação Nacional, que fundamentava o atendimento educacional às pessoas com deficiência, chamadas no texto de "excepcionais" (termo em desuso atualmente): "A Educação de excepcionais, deve, no que for possível, enquadrar-se no sistema geral de Educação, a fim de integrá-los na comunidade". Revogada pela Lei № 9.394, de 1996, exceto os artigos 60 a 9o;

Lei № 5.692/71: Lei de Diretrizes e Bases da Educação criada durante a Ditadura Militar (1964-1985), não promovia a inclusão de alunos com deficiências na rede regular, mas determinava uma escola especial para atender crianças com tal perfil. Revogada pela Lei oㅡ 9.394, de 20/12/1996;

Constituição Federal (1988): O artigo 208, que trata da Educação Básica, afirma que é dever do Estado garantir "atendimento educacional especializado aos portadores de deficiência, preferencialmente na rede regular de ensino". Nos artigos 205 e 206, afirma-se, respectivamente, "a Educação como um direito de todos, garantindo o pleno desenvolvimento da pessoa, o exercício da cidadania e a qualificação para o trabalho" e "a igualdade de condições de acesso e permanência na escola";

Lei № 7.853/89: O texto afirma que o poder público deve se responsabilizar pela "matrícula compulsória em cursos regulares de estabelecimentos públicos e particulares de pessoas portadoras de deficiência capazes de se integrarem no sistema regular de ensino";

Lei № 8.069/90: o Estatuto da Criança e do Adolescente garante o atendimento educacional especializado às crianças com deficiência preferencialmente na rede regular de ensino; trabalho protegido ao adolescente com deficiência e prioridade de atendimento nas ações e políticas públicas de prevenção e proteção para famílias com crianças e adolescentes nessa condição.

Lei № 9.394/96: A Lei de Diretrizes e Bases da Educação (LDB) tem um capítulo sobre a Educação Especial. Aborda que "o atendimento educacional será feito em classes, escolas ou serviços especializados, sempre que, em função das condições específicas dos alunos, não for possível a integração nas classes comuns de ensino regular". Além disso, a LDB trata da formação dos professores e de currículos, métodos, técnicas e recursos para atender às necessidades das crianças 
com deficiência, transtornos globais do desenvolvimento e altas habilidades ou superdotação.

Lei № 13.146/2015: A Lei Brasileira de Inclusão da Pessoa com Deficiência (Estatuto da Pessoa com Deficiência) que pondera desde a definição, atendimento prioritário, direitos à educação, inclusão, assistência social, entre outros à participação na vida pública e política além do reconhecimento de igualdade perante a Lei.

Decreto № 10.502: Política Nacional de Educação Especial de 30 de setembro de 2020 institui a chamada Política Nacional de Educação Especial: Equitativa, Inclusiva e com Aprendizado ao Longo da Vida, estimula a matrícula em escolas especiais, em que os estudantes com deficiência de certo modo, poderiam ficar segregados.

Podemos notar que há em nossa sociedade a compreensão da necessidade de aprimoramento constante da legislação referente às pessoas com deficiência. $A$ sociedade em constante mutação, com seus membros cada vez mais imperiosos na busca de direitos que the são tão facilitadores nas lutas diárias, precisa ter clareza das práticas que aprimorarão seu pleno desenvolvimento, e a busca por leis garantistas, eficazes e inclusivas, devem nortear o dia a dia de todos visando o bem-estar comum.

\section{ENSINO ESPECIAL E MEDIDAS DE INCLUSÃO NA EDUCAÇÃO}

No Brasil, a educação é um direito social. Somos um Estado social e democrático de Direito. Os direitos sociais foram erigidos à categoria de direitos fundamentais e desta maneira devem ser assegurados a todos os cidadãos.

A inclusão constitui um dos objetivos fundamentais da nossa República, uma vez que esta deve estar pautada na construção de uma sociedade livre, justa, solidária, que deve reduzir as desigualdades sociais e promover o bem de todos sem qualquer tipo de discriminação, como bem preceitua o Artigo $3^{\circ}$, I, III e IV da Constituição Federal.

Partindo desta premissa, faz-se importante atentar que esses objetivos não estejam apenas elencados na Lei maior, mas devem se tornar vivos e existentes no campo da vida diária de qualquer pessoa, principalmente das pessoas com deficiência. O termo estereotipado portador de necessidade especial ou portador de deficiência não são mais corretos em nossos dias. 
De acordo com o Decreto № 6.949 de 25/08/2009 (Convenção Internacional sobre os Direitos das Pessoas com Deficiência e seu Protocolo Facultativo) em seu artigo 1a, as pessoas com deficiência são as que têm impedimentos de longo prazo de natureza física, mental, intelectual ou sensorial, os quais, em interação com diversas barreiras, podem obstar sua participação plena e efetiva na sociedade em igualdades de condições com as demais pessoas.

No Brasil, o processo de inserção das pessoas com deficiência acompanhou as transformações desenroladas no âmbito internacional, que historicamente foi culturalmente excludente, sendo empreendidas medidas mais substanciais apenas na história recente, mas com alguns retrocessos e descontinuidades.

No campo educacional, podemos ressaltar algumas medidas que já são uma realidade em nossos meios educacionais.

A escola notadamente mostra-se um ambiente de interação e acolhimento. A oportunidade do trabalho de combate à falta de informação ou à informações errôneas e carregadas de preconceitos é clara e necessária. Compreende-se que todos os alunos têm capacidade de desenvolvimento cognitivo e social, amplamente trabalhado no ambiente escolar, e que todos devem aprender a ser, fazer, conhecer e conviver, como bem aduz a Unesco.

Uma garantia já aplicada em nosso sistema de ensino é o AEE (Atendimento Educacional Especializado), que trata da correta avaliação da prática educativa em relação aos alunos com deficiências e um atendimento mais individualizado e potencialmente mais eficiente e produtivo, orientando os docentes a conduzir de forma mais equivalente sua prática em relação a todos os alunos.

Os alunos com deficiência devem ser tratados como todos os demais, inclusive pelos próprios colegas de turma. A conscientização da diferenciação das atividades propostas é que deve ser dirigida e pode ser dirigida mesmo nos primeiros dias de aula, com uma conversa clara e respeitosa entre a comunidade escolar.

Treinamentos, semanas de conscientização para profissionais, responsáveis e alunos podem quebrar barreiras de comunicação e informações a respeito do tratamento igualitário necessário ao ambiente educacional.

É preciso também implementar ações que promovam mudanças sociais, a fim de que a discussão sobre a educação inclusiva não fique centrada no mundo das ideias, mas que se torne real e prática nas condutas diárias dos cidadãos. 
Faz-se necessário também a validação legal de políticas públicas que se mostrem eficazes para a prática docente, como o envio de materiais pedagógicos específicos e de qualidade que podem ser desde cartilhas, livros, computadores e espaços adaptados, e todo sistema tecnológico que pode e deve ser fornecido para transformar os debates sobre inclusão em práticas inclusivas, tornando a escola um verdadeiro espaço de inclusão.

O trabalho dos docentes merece ainda importante atenção. Dedicação, amor, capacidade e especialização tornam-se totalmente ineficazes se o professor continuar solitário em sua busca pela qualidade na educação, em salas de aula quentes, superlotadas, sem o mínimo de estrutura que assegure o seu trabalho, uma vez que todos os alunos merecem atenção especial e tranquilidade, sendo ainda mais necessário quando alunos com deficiências estão incluídos nas turmas.

Além disso, a escola deve ter a oportunidade de ter professores assistentes e uma equipe pedagógica com no mínimo um profissional por turno, habilitado para auxiliar os docentes a conduzirem seus trabalhos com primazia e de forma individualizada.

Uma Educação Inclusiva é o que se espera de toda a sociedade; garantir dignidade e inserção de indivíduos historicamente discriminados e subalternizados, não é um benefício, mas algo urgente e necessário para qualquer país que busque a plena integração dos seus cidadãos na sociedade.

A Educação Especial no Brasil ainda apresenta uma série de dificuldades e requer uma maior mobilização da sociedade civil, para que tais indivíduos possam ter seus direitos garantidos e qualidade de vida digna, como qualquer outro cidadão do país.

A jornalista Cláudia Werneck afirma sobre esta temática:

Na sociedade inclusiva ninguém é bonzinho. Ao contrário. Somos apenas e isto é o suficiente - cidadãos responsáveis pela qualidade de vida do nosso semelhante, por mais diferente que ele seja ou nos pareça ser. Inclusão é, primordialmente, uma questão de ética. (WERNECK, 2009).

O que acontece em nossos dias é que a Constituição Federal, nossa lei maior, orienta diretrizes a serem observadas pela sociedade, porém, os poderes públicos não fazem sua parte, auxiliando e informando adequadamente a população e fiscalizando o cumprimento da lei, gerando a Síndrome da Inefetividade das normas constitucionais, extremamente prejudicial ao convívio sadio e bem-estar social que 
implicará de forma negativa vários setores da sociedade, alcançando a comunidade escolar.

\section{CONSIDERAÇÕES FINAIS}

Através da análise histórico-social da inclusão dos indivíduos com deficiência, buscamos demonstrar o quanto tal trajetória foi longa, e intermediada por uma estrutura cultural excludente, que não possibilitava a tais cidadãos a sua inclusão plena na sociedade. Uma variedade de medidas legais foi elaborada, mas ainda há uma série de práticas que necessitam ser empreendidas por governos e sociedade civil. Para que tal cenário apresente melhorias, o papel da educação e da formação de profissionais habilitados é fundamental, além de maiores investimentos por parte do poder público. 


\section{REFERÊNCIAS}

BARBOSA, Daniella de Souza, FIALHO, Lia Machado Fiuza, MACHADO, Charliton José dos Santos. Educação inclusiva: aspectos históricos, políticos e ideológicos da sua constituição no cenário internacional. Revista Electrónica "Actualidades Investigativas En Educación ". Vol. 18, n. 2, Maio-Agosto. 1 de maio de 2018, pp. 1-20. Disponível em: $<$ https://www.scielo.sa.cr/pdf/aie/v18n2/1409-4703-aie-18-02-598.pdf/>. Acesso em: 10/02/2021.

BRASIL. Constituição da República Federativa do Brasil: promulgada em 5 de outubro de 1988. 22. ed. São Paulo: Saraiva, 2020.

Decreto № 6.949, de 25 de agosto de 2009. Convenção sobre os Direitos das Pessoas com Deficiência. Disponível em: <http://www.planalto.gov.br/ccivil_03/_ato20072010/2009/decreto/d6949.htm>. Acesso em: 07/03/2021.

CÂMARA DOS DEPUTADOS. ACESSIBILIDADE NA CÂMARA. TERMINOLOGIA SOBRE DEFICIÊNCIA. Disponível em: <https://www2.camara.leg.br/a-camara/estruturaadm/gestaonacamaradosdeputados/responsabilidadesocialeambiental/acessibilidade/glossarios/comofal arsobreaspessoascomdeficiencia\#: :text=termo\%20correto\%3a\%20pessoa\%20com\%20defi ci\%c3\%aancia.,no\%20feminino\%20e\%20no\%20plural>. Acesso em 07/03/2021.

CASAGRANDE, Rosana de Castro, CORCINI, Marli Aparecida Casprov. Educação Especial e sua trajetória histórico-política: uma abordagem por meio de grupos de discussão. In: Os desafios da escola pública paranaense na perspectiva do professor PDE. Paraná, 2016. Disponível em: <http://www.diaadiaeducacao.pr.gov.br/portals/cadernospde/pdebusca/ producoes_pde/2016/2016_artigo_edespecial_uepg_marliaparecidacasprovcorcini.pdf>. Acesso em: 10/02/2021.

EDUCAÇÃO INCLUSIVA: CONHEÇA O HISTÓRICO DA LEGISLAÇÃO SOBRE INCLUSÃO. Todos pela Educação, 04 de março de 2020. Disponível em: <HTTPS://TODOSPELAEDU CACAO.ORG.BR/NOTICIAS/CONHECA-O-HISTORICO-DA-LEGISLACAO-SOBREEDUCACAO-INCLUSIVA/>. Acesso em: 10/02/2021.

FERNANDES, Ana Paula Cunha dos Santos. (Org.). Educação especial: cidadania, memória, história. Belém: EDUEPA, 2017.

Inclusão, educação e Trabalho. Escola virtual de cidadania Flux. Disponível em: <https://escolavirtualdecidadania.camara.leg.br/flux/inclusao_educacao_e_trabalho/>. Acesso em: 07/03/2021.

MEC/SECADI. Política Nacional de Educação Especial na Perspectiva da Educação Inclusiva. Disponível em: <http://portal.mec.gov.br/arquivos/pdf/politicaeducespecial.pdf/>. Acesso em: 10/02/2021.

OLIVEIRA, Ivanilde Apoluceno de. Educação especial, direitos humanos e cidadania. In: FERNANDES, Ana Paula Cunha dos Santos (Org.) Educação especial: cidadania, memória, história. Belém: EDUEPA, 2017.

ROMANELLI, Otaíza de Oliveira. História da Educação no Brasil: (1930/1973). Petrópolis, RJ: Vozes, 2014. 
ROGALSKI, Solange Menin. Histórico do surgimento da educação especial. REVISTA EDUCAÇÃO DO IDEAU. Vol. 5, n. 12, Julho-Dezembro, 2010, pp. 1-13. Disponível em: $<$ https://www.passofundo.ideau.com.br/wpcontent/files_mf/eca97c3f3c5bda644479e4c6a858 f556168_1.pdf/>. Acesso em: 10/02/2021.

SASSAKI, R. Inclusão: construindo para todos uma sociedade. Rio de janeiro, WVA, 2010.

WERNECK, Cláudia. Ninguém mais vai ser bonzinho, na sociedade inclusiva. 3. ed. Rio de Janeiro: WVA, 2009. 


\section{CAPÍTULO 02}

DIFICULDADES PARA A EFETIVAÇÃO DA INCLUSÃO NO BRASIL: SISTEMATIZANDO A REALIDADE EM FỦNÇÃO DAS POLÍTICAS PÚBLICAS

\section{Fernando Icaro Jorge Cunha}

Universidade Federal do Pampa - Unipampa

Perfil: http://lattes.cnpq.br/149558185211586

E-mail:icaro729@gmail.com

\section{Gabriel Ferraz Martins}

Universidade Federal do Rio de Janeiro - UFRJ

Perfil: http://lattes.cnpq.br/8170278356375873

E-mail: gabrielferrazmtrs@gmail.com

\section{Ediane Kelly Soares Filocreão}

Advogada pela Universidade Estácio de Sá

Pedagoga pela Universidade Gama Filho

Perfil: http://lattes.cnpq.br/3871227153186585

E-mail:advsoaresfilocreao@gmail.com

\section{Lilian Patricia Soares Filocreão}

Universidade Federal do Estado do Rio de Janeiro

Perfil: http://lattes.cnpq.br/1950274050044786

E-mail: liliansfilocreao@gmail.com

\section{Maria José Baltar De Azambuja}

Secretaria Municipal de Porto Alegre-RS

Perfil: http://lattes.cnpq.br/8379431150091984

E-mail:mj.azambuja@bol.com.br

\section{Luciana Martins Vieira}

Secretaria Municipal de Educação de Porto Alegre-RS

Perfil: http://lattes.cnpq.br/4916051022113025

E-mail: lumartinsv@gmail.com

\section{Rita Freitas Ribeiro Pessano}

Secretaria Estadual de Educação do Rio Grande do Sul

Perfil: http://lattes.cnpq.br/4276364637043779

E-mail:ritapessano1982@gmail.com

Joel De Almeida Nunes

Universidade Luterana do Brasil, ULBRA

Perfil: http://lattes.cnpq.br/0869118201801878

E-mail: professordematematicams@gmail.com

\section{Janete Hickmann}

Rede de Ensino Municipal de São Leopoldo - RS 
Perfil: http://lattes.cnpq.br/0461298984464544

E-mail: janete22h@gmail.com

Resumo: O presente estudo traz, ao longo de seu desenvolvimento, alguns recortes sobre as Políticas de Educação Inclusiva frente a questões do mundo ideal e de uma realidade que ainda não foi alcançada. Nota-se na área Educacional e na Sociedade, de modo geral, a presença cada vez maior de pessoas com necessidades especiais nos espaços sociais. Tal visibilidade se justifica, em grande parte, pela superação de diferentes barreiras nos últimos anos, especialmente aquelas ligadas ao reconhecimento de direitos e aceitação familiar, e que impediam esses indivíduos de serem respeitados em suas diferenças, bem como gozar de acesso contínuo ao espaço comum da vida em sociedade. Sabe-se que todos, de modo geral, apresentam habilidades e competências diferentes, possuindo um tempo próprio e uma forma própria de aprendizagem de novos saberes. A conscientização de que uma pessoa com necessidades especiais pode e deve ser integrada aos espaços comuns de convívio, nos diferentes meios sociais, vem contribuir para, aos poucos, chegarmos a uma conscientização maior nos aspectos do respeito às diferenças, com o entendimento de que temos muito a aprender e também a ensinar.

Palavras-chave: Legislação da Educação Inclusiva; Convívio nos diferentes meios sociais; Desafios. 


\section{INTRODUÇÃO}

A proposta deste artigo é apresentar alguns pontos de vista acerca das dificuldades do processo de inclusão no Brasil, levando-se em conta a legislação brasileira sobre Educação Inclusiva, o contexto histórico e as diferentes crenças que permeiam o senso comum no tocante a pessoas portadoras de alguma necessidade especial, além da necessidade de conscientização da família de que essa pessoa pode e precisa estar inserida no meio social, junto às demais pessoas de nossa sociedade.

Desde a Declaração de Salamanca (1994), o tema da Educação inclusiva vem sendo cada vez mais debatido, sendo um dos objetos centrais de discussão a equidade de acesso à escolarização para pessoas com necessidades especiais (MENDES, 2002, p.64).

Muitos são os atravessamentos neste tema, que também podemos chamar de barreiras. As barreiras arquitetônicas são apenas um dos empecilhos que impedem que a inclusão dos alunos nas escolas seja efetivada. É o tipo de barreira que gera dificuldade para que a pessoa com deficiência possa fazer o uso pleno do meio, seja ele escolar ou não. Falta de estrutura e manutenção adequada das edificações são constantes, principalmente nas escolas públicas, que dependem da liberação de verbas para manter a estrutura em condições de oferecer um espaço seguro e adaptado para os alunos.

As barreiras atitudinais, como o nome já diz, estão relacionadas às atitudes dos envolvidos no processo educacional frente à inclusão dos alunos nas escolas regulares. São talvez as mais difíceis de eliminar, pois estão cristalizadas nas práticas de professores que exercem sua profissão da mesma forma por anos a fio.

\footnotetext{
É emergencial a promoção da Pedagogia contemplando a todos os sujeitos sociais, e não de uma pedagogia da pessoa com deficiência. promover uma Pedagogia da deficiência constitui uma das primeiras barreiras atitudinais percebidas no âmbito da educação. (LIMA E SILVA, 2012).
}

A legislação assegura que sejam respeitados e garantidos os direitos das pessoas com deficiência, mas leis por si só não bastam para garantir uma mudança de mentalidade e consequentemente de atitude: essa é uma mudança que deve vir de dentro para fora, a partir de iniciativas individuais e de pequenos coletivos. Uma mudança de atitude e de pensamento que urge ser colocada em prática. 


\section{FALTA DE INFRAESTRUTURA ESCOLAR: BARREIRAS ARQUITETÔNICAS, DE COMUNICAÇÃO, ATITUDINAIS E TECNOLÓGICAS}

O conceito de vulnerabilidade educacional é um conceito recente, que, como afirma Rodrigues (2018), se encontra ainda em construção no campo dos estudos pedagógicos. Diretamente relacionado ao conceito de vulnerabilidade social, ele envolve a discussão e evidenciação de fragilidades que perpassam o universo escolar, englobando desde problemas ligados à infraestrutura das escolas condições das instalações escolares, mobiliário etc -, até aqueles ligados à estrutura profissional - professores, diretores, merendeiras, pessoal de limpeza etc - e pedagógica - metodologias, teorias, apoio à formação continuada etc - das instituições escolares, comprometendo as condições de aprendizagem dos estudantes e o bem-estar social de todos aqueles que compõem o espaço escolar e estão envolvidos na ação de educar.

A rede pública de ensino, enquanto sistema organizado para ofertar a todos, de forma gratuita e universal, diversos níveis e modalidades de ensino, e de forma obrigatória, a educação básica, tem se mostrado mais sujeita a situações de vulnerabilidade educacional. Tal condição se justifica pelo próprio desafio de ofertar a uma população diversa em termos econômicos, sociais, étnicos, culturais, intelectuais, físicos, sensoriais e de gênero, em territórios diversos e, em boa parte, sujeitos a condições de vulnerabilidade social, um ensino de qualidade que poucas vezes conta com os recursos, o pessoal e a infraestrutura adequados ao cumprimento dessa função.

A lei prevê que a escola esteja preparada em sua estrutura arquitetônica, pedagógica e profissional para esta busque meios e recursos a fim de contemplar os objetivos da Educação Inclusiva (VIANNA, 2013). No entanto, um número alarmante de escolas brasileiras sofre ainda com a falta de uma infraestrutura básica, conforme apontam os dados dos Censos Escolares de 2018 e 2020, promovidos pelo Instituto Nacional de Estudos e Pesquisas Educacionais Anísio Teixeira (Inep).

Em 2018, por exemplo, banheiros adequados a alunos com deficiência ou mobilidade reduzida estavam disponíveis em apenas $34,3 \%$ das escolas municipais, $55,6 \%$ das escolas privadas, $53,7 \%$ das estaduais e $76,6 \%$ das federais. Dependências e vias adequadas para o mesmo público eram encontradas em apenas 
$24,4 \%$ das escolas municipais, 40,7 \% das estaduais, 44,7 \% das escolas privadas e $63,8 \%$ das federais (INEP, 2019).

A partir de 2019, o Inep deixou de incluir informações acerca do saneamento e abastecimento básico das escolas públicas no Censo Escolar, além de ter sido reduzido o acesso a informações a respeito de condições de acessibilidade para alunos com deficiência ou mobilidade reduzida nas escolas, sob a justificativa de "avaliar a necessidade de inserção de novos campos que se adequem melhor à realidade das escolas brasileiras, bem como a exclusão de campos desatualizados ou em desuso" (INEP, 2020, p. 11). Mas como é que índices tão elevados podem ser considerados desnecessários, campos desatualizados ou em desuso?

No que diz respeito a recursos de acessibilidade, apontam os reduzidos novos dados do Censo Escolar de 2020 que apenas 48,9 \% das escolas estaduais, e 51,1 \% das escolas municipais possuem algum tipo de recurso de acessibilidade para os alunos com deficiência da Educação Infantil - informações sobre as demais modalidades de ensino não são disponibilizadas. O processo de inclusão indica progresso no tocante à integração de alunos com deficiência $(P c D)$, transtornos globais do desenvolvimento (TGD) ou altas habilidades/superdotados (AH/SD) em escolas regulares: em 2016, o percentual de matrículas em classes comuns cresceu de 89,5 \% em 2016 para 93,3 \% em 2020 (INEP, 2021). No entanto, se tal dado indica que uma barreira foi rompida no tocante à inclusão em escolas regulares, não esclarece se a formação dos professores tem sido condizente com essa nova realidade, ou ainda se o Atendimento Educacional Especial (AEE), é ofertado conforme a demanda.

Em tempos de pandemia de Covid-19, isolamento social e ensino remoto, a situação evidenciou ainda mais a condição de vulnerabilidade educacional das instituições públicas de ensino, especialmente para com os estudantes com necessidades educacionais especiais.

"Durante a pandemia, crianças que já apresentavam progressos e consideráveis avanços no que diz respeito à autonomia e autoconfiança retrocederam em virtude da ausência desses profissionais. Eles atuavam de forma especializada e estabeleciam uma rotina necessária ao bom desempenho do aluno, mas tiveram sua atuação impedida pela suspensão das aulas presenciais [...]. As escolas encontraram muita dificuldade com a nova adaptação da grade curricular [...]. Não existia nenhuma estrutura de informatização do ensino, desde uma plataforma, até um local adequado para os professores gravarem suas aulas. E, diante deste quadro, como os educadores poderiam adaptar as aulas para as crianças com deficiência no âmbito da motricidade e raciocínio?" (JAKUBOWICZ, 2020). 
Além da deficiência de planejamento das instituições de ensino para com as Tecnologias de Informação e Comunicação (TIC's), outro agravante envolve a situação de desigualdade de acesso a recursos tecnológicos que vivenciam os grupos socioeconomicamente mais vulneráveis. De acordo com a pesquisa TIC Domicílios 2019, que avalia o acesso a recursos de tecnologias de informação nos domicílios brasileiros, em famílias cuja renda é de até um salário mínimo, metade não consegue navegar na rede em casa e, apesar do celular estar presente em $85 \%$ dos lares das classes $\mathrm{D}$ e $\mathrm{E}$, nem todos os alunos possuem um celular à sua disposição para os estudos - havendo apenas um aparelho disponível, e que é, entretanto, utilizado pelo pai, mãe ou responsável para trabalhar, ficando a disposição da criança apenas após o horário do expediente de trabalho. A insuficiência de computadores conectados à internet é um problema mencionado por $91 \%$ dos professores da rede municipal e por $45 \%$ dos professores de colégios particulares consultados pela pesquisa, o que informa sobre a urgência de políticas públicas nesse âmbito (TENENTE, 2020).

A Educação Inclusiva, enquanto concepção de ensino, prevê a integração de todos no ambiente escolar, busca a igualdade de oportunidades, a valorização das diferenças humanas, demandando um ensino adequado às diferenças e necessidades de cada aluno, o que implica na adaptação da cultura, práticas e políticas escolares, de modo a garantir o acesso e a aprendizagem de todos, sem exceção. Para tanto, um aspecto indispensável para a efetivação desse processo de inclusão é a formação adequada e contínua do professor, bem como dos demais profissionais envolvidos no processo educativo.

A legislação brasileira prevê que os cursos de formação devem capacitar os professores para a interação com alunos que demandam necessidades educacionais especiais. Conforme salienta Sônia Maria Rodrigues:

Os professores capacitados, para serem assim denominados, devem ter uma disciplina em sua formação inicial a respeito da educação especial e da educação inclusiva, além de adquirir competências para perceber as necessidades educacionais específicas dos estudantes e flexibilizar a ação pedagógica para atender às suas especificidades. (RODRIGUES, 2012).

Entretanto, pesquisas indicam falhas curriculares nesse quesito. Em consulta realizada com professores de Ensino Fundamental e Médio do Estado do Acre, 70 \% do total de professores entrevistados revelaram que não obtiveram, em sua formação, conhecimentos sobre como lidar em sala de aula com alunos portadores de necessidades especiais (OLIVEIRA, 2012). Análises de matrizes curriculares de 
cursos de licenciatura, como a realizada por Dias e Silva (2020) em uma universidade pública baiana, demonstram que, infelizmente, essa ausência de disciplinas que abordem a Educação Inclusiva em instituições de ensino superior não é uma realidade isolada.

Problemas de infraestrutura, falta de capacitação e referência pedagógica sobre Educação Inclusiva são, assim, algumas das principais vulnerabilidades que demarcam os espaços escolares das redes públicas de ensino no tocante ao desafio da inclusão.

\section{BARREIRAS QUANTITATIVAS: APLICAÇÃO DE VERBAS E RECURSOS PÚBLICOS}

O financiamento da educação é elemento estruturante para a organização e o funcionamento das políticas públicas educacionais e, desse modo, para materialização do Sistema Nacional de Educação. Embora não seja fator suficiente, é condição necessária para a universalização do direito à educação pública de qualidade (NOVO, 2018).

No Brasil, a trajetória histórica da educação especial iniciou-se atrelada às ações isoladas, desenvolvidas no Ministério da Educação e Cultura, primeiramente para criação de instituições especializadas federais e, na sequência, de cessão de aportes voltados à instalação, manutenção e expansão de instituições privadas de caráter assistencial, inaugurando um período de aplicação de verbas públicas da educação, da saúde e/ou da assistência social, no setor privado, nesse caso de natureza filantrópica. Somente no final dos anos 1950 e início da década de 1960 o Estado brasileiro começa a assumir a educação especial como política pública, mas não sem manter o financiamento a serviços privados (MAZZOTTA, 2011).

A partir do final de 1990, acontece a reconfiguração das funções do Estado e das políticas sociais, e o financiamento da educação especial começa a ficar distante do estado e passa a ter um caráter mais capitalista.

Historicamente, segundo Ferreira (2009, p.55), "os parcos recursos do Estado dirigido a essa modalidade de ensino, eram dirigidos mais às instituições filantrópicas que tinham centralidade na política e na gestão da educação especial."

A Constituição de 1988 em seu artigo 205 diz que: 
A educação, direito de todos e dever do Estado e da família, será promovida e incentivada com a colaboração da sociedade, visando ao pleno desenvolvimento da pessoa, seu preparo para o exercício da cidadania e sua qualificação para o trabalho. (BRASIL, 1988).

O dever do Estado no que se refere à Educação Especial está definido no artigo 208, alínea III, que garante o "atendimento educacional especializado aos portadores de deficiência, preferencialmente na rede regular de ensino". (BRASIL, 1988).

No entanto, o que temos visto é um dever delegado à família, a sociedade civil, ONGs e outras instituições por parte do poder público no que se refere ao atendimento e na aplicação de verbas e recursos para esse público.

De acordo com Viegas e Bassi (2009, p. 54), "a expansão do atendimento à Educação Especial, assim como as demais etapas e modalidades da educação básica, passou a ser condicionada pela política de fundos contábeis implantada a partir de 1996."

O Fundo de Manutenção e Desenvolvimento do Ensino Fundamental e de Valorização do Magistério (Fundef), criado neste ano (BRASIL, 1996), e o Fundo de Manutenção e Desenvolvimento da Educação Básica e de Valorização dos Profissionais da Educação (Fundeb), que substituiu o Fundef a partir de 2007 (BRASIL, 2006), alteraram a trajetória dos recursos públicos oriundos da vinculação da receita dos impostos destinada à manutenção e desenvolvimento do ensino, estabelecida na Constituição Federal de 1988 (CF/88). (VIEGAS e BASSI, 2009).

Portanto, desde 1988, a União deve assegurar $18 \%$ da sua receita de impostos na manutenção e desenvolvimento do ensino, e o estado e municípios, 25\% dessa receita. O ensino público conta ainda com a Contribuição Social do Salário-Educação, instituído em 1964.

Na educação Especial, a legislação do Fundef determina um valor mínimo por aluno/ano diferenciado, de acordo com o nível de ensino e o tipo de estabelecimento, que leva em conta o custo por aluno.

Somente a partir de 2000 entra em vigor esta diferenciação ao elevar o valor mínimo por aluno das matrículas da 5a a 8aㅗ série e de Educação Especial no ensino fundamental em ínfimos $5 \%$ superiores ao valor das matrículas na $1^{\underline{a}}$ a $4^{\underline{a}}$ série. Em 2005, nova diferenciação elevou em 7 \% o valor mínimo por aluno da Educação Especial, junto com o das séries finais identificados na zona rural, em relação ao valor repassado para as matrículas nas primeiras quatro séries (VIEGAS e BASSI, 2009). 
De 2007 a 2013 houve um aumento de 53 \% no valor aluno/ano da educação especial, e o aumento contínuo no valor aluno/ano tem contribuído significativamente no aumento das matrículas desses alunos, no sistema de educação pública brasileira.

Embora o Fundeb tenha contribuído para o aumento de verbas destinadas às etapas e modalidades da educação básica, o seu direcionamento continuou a depender fortemente das decisões, negociações e correlações de forças de interesse no âmbito do governo local, que define, em última instância, a destinação de recursos para as diferentes etapas da educação básica e modalidades de ensino no contexto de sua administração (GOUVEIA; SILVA, 2012).

Ressaltamos ainda, que as verbas e recursos públicos, podem ser destinados a entidades privadas de Educação Especial, o que está previsto na legislação do FUNDEB, para o oferecimento de serviços a essa população.

\section{BARREIRAS QUALITATIVAS: INADEQUAÇÃO DE PRÁTICAS PEDAGÓGICAS E ADMINISTRATIVAS}

A efetivação de uma educação inclusiva encontra na realidade pedagógica um conjunto de obstáculos de ordem histórica cuja permanência têm provocado, no espaço escolar e na sociedade como um todo, desencontros de toda ordem.

Nessa sessão denominaremos tais obstáculos de barreiras qualitativas, que estão diretamente ligadas à inadequação de práticas pedagógicas e administrativas presentes no espaço escolar.

Salas de aula inclusivas pressupõem que todos os discentes podem aprender e fazer parte da vida escolar e comunitária, de tal sorte que a diversidade é valorizada.

Destacamos que educar todos em salas de aula regulares é um dos elementos importantes para a ruptura das barreiras qualitativas, uma vez que todos recebem oportunidades educacionais adequadas, que são desafiadoras, porém ajustadas às suas habilidades e necessidades; recebem todo o apoio e ajuda de que eles ou os seus professores possam, da mesma forma, necessitar para alcançar sucesso nas suas atividades.

A educação é uma questão de direitos humanos, e os indivíduos com deficiências devem fazer parte das escolas, as quais devem modificar seu funcionamento para incluir todos os discentes - esta é a mensagem que foi claramente 
transmitida pela Conferência Mundial de 1994 da UNESCO - sobre Necessidades Educacionais Especiais.

Ainda encontramos muita resistência na presença de indivíduos com deficiência em classes regulares, sendo que essa resistência vem de vários segmentos: da própria escola, dos docentes, dos pais dos indivíduos com deficiência, etc.

Se o propósito é realizar o ensino inclusivo, os professores em geral, diretores e os demais profissionais especializados, devem aliar-se em um esforço unificado e consistente.

Outro obstáculo importante para a efetivação da educação inclusiva diz respeito à reduzida presença de uma rede de apoio. A rede de apoio é o componente organizacional, que envolve a coordenação de equipes e de indivíduos que apoiam uns aos outros, através de conexões formais e informais, viabilizando a inclusão.

Também devemos citar a centralidade da denominada consulta cooperativa e o trabalho em equipe, o componente do procedimento que envolve indivíduos de várias especialidades trabalhando juntos, para planejar e implementar programas para diferentes discentes em ambientes integrados.

Outro elemento de suma importância para efetivar a inclusão, diz respeito à denominada aprendizagem cooperativa, que está relacionada à criação de uma atmosfera de aprendizagem em sala de aula em que alunos com vários interesses e habilidades possam atingir o seu potencial.

Uma característica dessa aprendizagem que a difere do modo tradicional é a sua interação social, ou seja, não há como se estabelecer um trabalho cooperativo se não for possível a interação face a face entre os estudantes, permitindo assim que os mesmos interajam e compartilhem seu conhecimento, melhorando a sua compreensão individual e mútua sobre um determinado conteúdo. Nesse sentido, na aprendizagem cooperativa, além do conhecimento adquirido e compartilhado, os sujeitos envolvidos desenvolvem habilidades interpessoais que vão além da vida acadêmica (TEIXEIRA; REIS, 2011).

Os discentes aprendem muitas habilidades acadêmicas e também habilidades da vida diária, de comunicação e sociais, através de interações com seus pares. Todos, incluindo aqueles com deficiências, precisam de interações educandoeducador e educando-educando que moldem habilidades acadêmicas e sociais. 
Destacamos ainda que fortalecer uma educação cooperativa, rompendo com a perspectiva individualista, pode contribuir para que um educando com deficiência possa não ser capaz de absorver todo o currículo da educação regular, ele pode beneficiar-se das experiências não acadêmicas no ambiente educacional regular, resultando daí a necessidade de rompermos com esse paradigma da aprendizagem individual.

Do ponto de vista acadêmico, social e ocupacional, as colocações segregadas são prejudiciais aos alunos. Após realizar uma série de estudos, Welhman (1990) concluiu que "as turmas segregadas não conduzem à independência e à competência, mas estimulam uma sensação irrealista de isolamento".

Em contrapartida, a educação inclusiva proporciona às pessoas com deficiência a oportunidade de adquirir habilidades para o trabalho e para a vida em comunidade. Os educandos com deficiência aprendem como atuar e interagir com seus pares no mundo "real". Igualmente importante, seus pares e também os professores aprendem como agir e interagir com eles.

A razão mais destacada para o ensino inclusivo é o valor social da igualdade. Ensinamos os educandos através do exemplo de que, apesar das diferenças, todos nós temos direitos iguais. Em contraste com as experiências passadas de segregação, a inclusão reforça a prática da ideia de que as diferenças são aceitas e respeitadas.

A barreira social para a inclusão antes referida destaca a questão do respeito e da igualdade na diversidade como um direito fundamental que precisa ser difundido, cabendo à escola este papel.

A forma como as escolas são organizadas, ainda bastante centralizadas e burocratizadas, dificulta o envolvimento e a participação da comunidade nas deliberações da mesma. Nesse sentido, o esforço para romper com esse obstáculo passa necessariamente por modificar esse cenário, o que pode ser feito na medida em que somos capazes de:

- Proporcionar meios através dos quais os professores possam aprender novas práticas educacionais;

- Encontrar maneiras de estabelecer relações pessoais entre todos os alunos da escola; 
- Ajudar a escola como um todo a tornar-se acolhedora e a manter-se como uma comunidade (EDUCAÇÃO INCLUSIVA - DIREITO À DIVERSIDADE - IBRA).

O esforço de romper com esse conjunto de obstáculos se coloca como um desafio importante de todos os educadores. Somente quando enfrentarmos essas questões seremos capazes de viabilizar uma educação inclusiva. Na sequência, apresentamos algumas estratégias que podem ser usadas para viabilizar essa inclusão:

- Promover objetivos mais cooperativos do que competitivos nas salas de aula e na escola;

- Estabelecer rotinas na sala de aula e na escola, em que todos recebam o apoio necessário para participar de forma igual e plena;

- Encontrar oportunidades para apresentar os educandos diferentes de uma maneira positiva para seus colegas e para outros adultos na escola;

- Garantir que em toda atividade de sala de aula e da escola, sejam feitas acomodações para que todos, inclusive os educandos com necessidades especiais, possam participar ativamente;

- Infundir valores positivos de respeito, de apreciação pelas pessoas diferentes e de cooperação no desenvolvimento do próprio currículo;

- Envolver os educandos na tomada de decisão com relação a políticas de apoio mútuo, nas salas de aula e na escola (EDUCAÇÃO INCLUSIVA - DIREITO À DIVERSIDADE - IBRA).

\section{POLÍTICAS PÚBLICAS INCLUSIVAS E LEGISLAÇÃO}

Há muitos anos as Políticas Educacionais Inclusivas buscam dar conta das demandas apresentadas pelas sociedades. Políticas que se iniciaram com Leis, Decretos e Notas Técnicas de Políticas Públicas. Mas, no Brasil, essa caminhada das é recente (MAZZOTTA, 1996).

Inicialmente houve uma recomendação para que o aluno especial frequentasse o Ensino Regular. Passados alguns anos, passou a ser obrigatória a oferta de vagas no Ensino regular, apesar do processo de formação docente para atender essa demanda ainda se apresentar de forma ineficiente, o que causava, não raro, um 
processo de exclusão - e não a própria inclusão que se pretendia -, isso em virtude de diversos fatores.

Cabe lembrar que a Inclusão é um direito de todos, e que o papel da família junto à Escola precisa ser cada vez mais fortalecido para que essa rede de apoio entre Família e Escola traga progressos ao desenvolvimento do educando.

As dificuldades enfrentadas tanto pelo Educador quanto para o Educando são muitas. Embora existam as políticas inclusivas, essas, por si só, não dão conta de atuar em todos os aspectos da prática pedagógica, como na relação aluno-professor (BUENO, 1998).

As dificuldades de apoio financeiro implicam muito no resultado das aprendizagens dos mesmos. Os Educadores precisam ser criativos e autônomos nos seus planejamentos, fazendo uso, muitas vezes, de materiais reciclados para confecção de jogos e materiais que venham facilitar as aprendizagens.

\section{CONSIDERAÇÕES FINAIS}

Partindo das análises feitas nas leis que regulamentam a Educação Especial e Inclusiva no Brasil, e das vivências dos/as educadores/as, percebemos que o Estado tem deveres para com a Educação Especial, que ao longo dos anos foram estipulados, através de leis, para que realmente houvesse benefícios no ensino especial e inclusivo no país.

A partir da leitura deste capítulo, observamos que a Educação Brasileira enfrentou diversas mudanças no cenário Educacional. Mudanças que não param por aí, pois muito ainda precisa ser feito para que a sociedade se conscientize do quanto o trabalho colaborativo entre Família e Escola é fundamental para o avanço dos seus filhos; além disso, um forte investimento por parte das políticas públicas na formação e conscientização dos professores, bem como investimentos em materiais pedagógicos, para que esses profissionais possam alcançar uma grande potencialidade nas habilidades apresentadas por cada sujeito, que é singular em suas competências e possui seu tempo próprio para aprender.

Realizar um trabalho cooperativo entre poder público, escola e família, tornará a Educação Especial Inclusiva uma realidade nas escolas brasileiras. Mas não podemos esquecer do papel preponderante que o Estado possui de ajudar 
financeiramente, e também de fiscalizar para que as leis realmente sejam cumpridas, desde o ensino da Educação Especial e Inclusiva nas graduações, cursos técnicos (como Curso Normal) e demais especializações; acessibilidade nas escolas para que todos os educandos que possuem necessidades especiais e inclusivas sintam-se acolhidos pela comunidade escolar, e para que a família desse aluno também possa obter o acolhimento e a ajuda necessários para que, juntamente com os professores, ocorra uma educação significativa e uma socialização inclusiva de fato. 


\section{REFERÊNCIAS}

ASSOCIAÇÃO BRASIL SAÚDE E AÇÃO - BRASA. https://www.brasa.org.br/. Acesso em 18 abr. 2021.

BRASIL, Constituição (1988). Constituição da República Federativa do Brasil. Brasília, DF: Senado Federal, 1988.

BUENO, Nunes. A formação do professor especialista. São Paulo: Vozes, 1998.

DIAS, V. B.; SILVA, L. M. Educação Inclusiva e formação de professores: o que revelam os currículos dos cursos de licenciatura? Práxis Educacional, Vitória da Conquista - BA, v. 16, n. 43 , p. 406-429, dez. 2020.

FERREIRA, J. R. Financiamento da educação básica: o público e o privado na educação especial brasileira. In: FÁVERO, O; et. al. Tornar a educação inclusiva. Brasília: UNESCO, 2009.

GOUVEIA, Andrea Barbosa; SILVA, Isabelle Fiorelli. O gasto aluno-ano no Paraná (Brasil) e a situação de financiamento da educação nas regiões metropolitanas do estado.

Perspectiva, Florianópolis, v. 30, n. 1, 2012.

GRUPO EDUCACIONAL IBRA. Educação Inclusiva: Direito à Diversidade, Complementação Pedagógica. Disponível em: <http://www.passeidireto.com/arquivo/92868946/23-educacaoinclusiva-direito-a-diversidade-apostila>. Acesso em: 30/07/2021.

Resumo Técnico: Censo da Educação Básica 2019. Brasília: Instituto Nacional de Estudos e Pesquisas Educacionais Anísio Teixeira, 2020. Disponível em:

$<$ https://download.inep.gov.br/publicacoes/institucionais/estatisticas_e_indicadores/resumo_t ecnico_censo_da_educacao_basica_2019.pdf>. Acesso em: 14 abr. 2021.

Resumo Técnico: Censo da Educação Básica 2020. Brasília: Instituto Nacional de Estudos e Pesquisas Educacionais Anísio Teixeira, 2021. Disponível em: $<$ https://download.inep.gov.br/publicacoes/institucionais/estatisticas_e_indicadores/resumo_t ecnico_censo_escolar_2020.pdf>. Acesso em: 14 abr. 2021.

JAKUBOWICZ, D. S. C. A educação de estudantes com deficiência em tempos de pandemia. Diversa, São Paulo, 07 dez. 2020. Disponível em:

$<$ https://diversa.org.br/artigos/a-educacao-de-estudantes-com-deficiencia-em-tempos-depandemia/>. Acesso em: 15 abr. 2021.

LIMA Francisco J. e SILVA Fabiana Tavares dos Santos. Barreiras atitudinais: obstáculos à pessoa com deficiência na escola. 2012. Disponível em:

https://www.deficienteciente.com.br/barreiras-atitudinais-obstaculos-a-pessoa-comdeficiencia-na-escola.html. Acesso em 30 de abril de 2021.

MAZZOTTA, M. J. S. Educação Especial no Brasil: história e políticas públicas. São Paulo, Cortez. 1996.

2011.

Educação Especial no Brasil: história e políticas públicas. São Paulo: Cortez, 
MENDES, E. G. Perspectivas para a construção da escola inclusiva no Brasil. In: PALHARES, Marina Silveira e MARINS, Simone. Escola Inclusiva. São Carlos: EdUFSCar, 2002. p. 61-83.

OLIVEIRA, E. et al. Inclusão social: professores preparados ou não? POLÊM!CA Revista Eletrônica, Rio de Janeiro, v. 11, n. 2, pp., mai./ago. 2012. Disponível em: <https://www.epublicacoes.uerj.br/index.php/polemica/article/view/3103/2206>. Acesso em 16 abr. 2021.

RODRIGUES, S. M. Educação inclusiva e formação docente. Diversa, São Paulo, 26 jun. 2012. Disponível em: <https://diversa.org.br/artigos/educacao-inclusiva-e-formacaodocente/>. Acesso em 17 abr. 2021.

RODRIGUES, W. Construindo o conceito de vulnerabilidade educacional. Revista Panorâmica, Barra do Garças - MT, v. 24, p. 151-160, jan./jun. 2018.

TEIXEIRA, Madalena Telles, REIS, Maria Filomena. A Organização do Espaço em Sala de Aula e as Suas Implicações na Aprendizagem Cooperativa. Revista Meta: Avaliação, v. 4, 2011.

TENENTE, Luiza. 30\% dos domicílios no Brasil não têm acesso à internet; veja números que mostram dificuldades no ensino à distância. Portal G1, São Paulo, 26 mai. 2020. Disponível em: <https://g1.globo.com/educacao/noticia/2020/05/26/66percent-dosbrasileiros-de-9-a-17-anos-nao-acessam-a-internet-em-casa-veja-numeros-que-mostramdificuldades-no-ensino-a-distancia.ghtml>. Acesso em: 15 abr. 2021.

VIANNA, P. et al. Educação inclusiva: espaço físico, prática pedagógica e gestão na perspectiva da ação inclusiva. Revista Educação em Rede: Formação e Prática Docente, Cachoeirinha - RS, v. 2, n. 2, p. 50-64, jan./dez. 2013.

VIEGAS, Luciane Torezan; BASSI, Marcos Edgar. A educação especial no âmbito da política de fundos no financiamento da educação. Reflexão e ação, v. 17, p. 54-87, 2009. 


\section{CAPÍTULO 03}

O DESAFIO DE INCLUIR E A NECESSIDADE DE INOVAR: UM DIÁLOGO ENTRE AS DEFICIÊNCIAS E OS SUBSÍDIOS PEDAGÓGICOS

\section{Fernando Icaro Jorge Cunha}

Universidade Federal do Pampa - Unipampa

Perfil: http://lattes.cnpq.br/149558185211586

E-mail: icaro729@gmail.com

\section{Maria José Baltar Azambuja}

Rede Municipal de Porto Alegre-RS

Perfil: http://lattes.cnpq.br/8379431150091984

E-mail:mj.azambuja@bol.com.br

\section{Janete Hickmann}

Rede de Ensino Municipal de São Leopoldo - RS

Perfil: http://lattes.cnpq.br/0461298984464544

E-mail: janete22h@gmail.com

\section{Leonice Aparecida De Fátima Alves Pereira Mourad}

Universidade Federal de Santa Maria - UFSM

Perfil: http://lattes.cnpq.br/7689442989367017

E-mail:profleomourad@gmail.com

\section{Letícia Neutzling Benites}

Rede Municipal de Porto Alegre-RS

Perfil: http://lattes.cnpq.br/9538992073439454

E-mail: letizen2003@yahoo.com.br

\section{Rejane Marques Alves}

Professora da Rede Municipal de Ensino de Porto Alegre

Perfil: http://lattes.cnpq.br/5724478487166386

E-mail: rejrejmarques@gmail.com

Resumo: O presente capítulo é um artigo de revisão bibliográfica que faz uma relação entre o desafio de alcançar a inclusão escolar eficiente em função da necessidade de articular os subsídios didático-pedagógicos. Para mediar essa reflexão, no primeiro momento foi aprazado os eixos introdutórios sobre as deficiências, deficiências múltiplas e algumas considerações sobre a estruturação necessária para a articulação da inclusão. No segundo momento, foi destacado uma síntese de aspectos importantes que norteiam a valia da inclusão, com a utilização dos jogos e do lúdico como estratégia pedagógica, propiciando a eficácia da aprendizagem. Além disso, foram problematizadas algumas relevâncias sobre a deficiência intelectual e as altas habilidades.

Palavras-chave: Deficiência; Subsídios; Desafios. 


\section{INTRODUÇÃO}

A deficiência não é algo que emerge com o nascimento de alguém ou com a enfermidade que alguém contrai, mas é produzida e mantida por um grupo social na medida em que interpreta e trata como desvantagens certas diferenças apresentadas por determinadas pessoas. (BRIZOLLA, 2021). Assim as deficiências devem, a nosso ver, ser encaradas também como decorrentes dos modos de funcionamento do próprio grupo social e não apenas como atributos inerentes às pessoas identificadas como deficientes.

Os processos de inclusão e ou integração escolar variam de um país para outro, mesmo que defendam uma escola para todos. Promover uma integração efetiva não significa abolir a educação especial, mas incorporá-la à regular. É tornar a educação especial em regular e vice-versa, portanto, falar em integração significa falar em integrar esforços e recursos. (BRIZOLLA, 2021).

Discussões e estudos recentes realizados por equipes de profissionais que tratam da educação Especial, demonstram que o trabalho colaborativo é extremamente significativo no processo de inclusão. Uma relação de parceria e colaboração entre os diversos níveis educacionais implica em uma proposta pedagógica inclusiva.

Trabalhar em colaboração com os demais profissionais, planejando, tentando solucionar os problemas que se apresentam em relação à aprendizagem dos alunos, desenvolver mudanças, tomar decisões em conjunto, cria possibilidades de sucesso pedagógico na tarefa de promover uma educação de qualidade aos educandos.

Mas, para que isso ocorra é preciso fortalecer a formação dos professores e estabelecer uma rede de apoio entre alunos, docentes, gestores, famílias e profissionais da saúde que atendem as crianças com Necessidades Educacionais Especiais.

São considerados público alvo da Educação especial na perspectiva da Educação inclusiva, educandos com deficiência (intelectual, física, auditiva, visual e múltipla), transtorno global do desenvolvimento (TGD) e altas habilidades.

A reestruturação física, com a eliminação das barreiras arquitetônicas; a introdução de recursos e de tecnologias assistivas; a oferta de profissionais do ensino 
especial, além da compreensão e incorporação desses serviços na escola regular são subsídios necessários à organização, ao planejamento e à avaliação do ensino.

Porém, antes de tudo é preciso inovar, segundo Lopes (2016), quando vemos as escolas transformadoras e inovadoras, percebemos que muitas delas têm feito um bom trabalho de inclusão das crianças com deficiência porque estão priorizando no seu projeto pedagógico a questão do clima, do acolhimento e do respeito às singularidades.

Começar a pensar em processos educacionais mais centrados nas especificidades dos alunos, abre caminhos para tornar a escola realmente inclusiva e inovadora.

Para que a igualdade seja real, ela tem que ser relativa. Isto significa que as pessoas são diferentes, têm necessidades diversas e o cumprimento da lei exige que a elas sejam garantidas as condições apropriadas de atendimento às peculiaridades individuais, de forma que todos possam usufruir as oportunidades existentes. Há que se enfatizar aqui, que tratamento diferenciado não se refere à instituição de privilégios, e sim, à disponibilização das condições exigidas, na garantia da igualdade (BRASIL, 2004, p.10).

O desafio é valorizar a diversidade, pois, a educação inclusiva diz respeito a todos, porém, o maior desafio é superar o preconceito que ainda acontece por falta de conhecimento e reconhecimento do outro como um igual.

\section{A INCLUSÃO DE ALUNOS COM DEFICIÊCIAS MÚLTIPLAS}

A inclusão como direito se apresenta hoje como inquestionável. No nível da formulação de políticas, leis e documentos nacionais e internacionais constituem os meios de assegurar esse direito a todos. O Plano Nacional de Educação (PNE) estabelece que a inclusão perpasse todas as etapas de ensino, da Educação Infantil ao Ensino Superior. Tal regulamentação ainda define que o atendimento educacional especializado (AEE) e a disponibilização de serviços e recursos para orientar os alunos e professores do ensino regular a esse respeito são premissas da Educação brasileira. E assim é assegurada a inclusão de alunos com deficiências múltiplas.

A deficiência múltipla é uma associação de duas ou mais deficiências primárias como física, mental, visual ou auditiva, no mesmo indivíduo. As pessoas com deficiências múltiplas apresentam comprometimento que causam atrasos no desenvolvimento, na aprendizagem e na capacidade administrativa. Segundo a Política Nacional de Educação Especial (PNEE) a deficiência múltipla é uma 
"associação, no mesmo indivíduo, de duas ou mais deficiência primárias (mental/visual/auditiva/física) com comprometimento que acarretam atrasos no desenvolvimento global e na capacidade adaptativa (MEC,1994). O decreto federal $\mathrm{n}^{\circ}$ 5.296 explica que deficiência múltipla é uma "associação de duas ou mais deficiências" podendo ser de ordem física, sensorial, mental, emocional ou de comportamento social, podendo ser agravada por alguns aspectos, tais como a idade de aquisição, o grau das deficiências e a quantidade de associações que o indivíduo apresenta. Importa ressaltar que o que caracteriza a deficiência múltipla, é o "nível de desenvolvimento, as possibilidades funcionais, de comunicação, interação social e de aprendizagem que determinam as necessidades educacionais dessas pessoas" (GODOI, 2006, p. 11).

São variadas as causas que envolvem a deficiência múltipla, podendo ser ordem sensorial, motora e linguística e originada de "fatores pré-natais, perinatais ou natais e pós-natais, além de situações ambientais tais como: acidentes e traumatismos cranianos, intoxicação química, irradiações, tumores e outras" (SILVA, 2011).

As deficiências múltiplas podem se apresentar mediante a associação das seguintes categorias, entre outras: física e psíquica (deficiência física associada à deficiência intelectual ou ao transtorno mental); sensorial e psíquica (deficiência auditiva ou surdez associada à deficiência intelectual ou deficiência visual ou cegueira associada à deficiência intelectual ou ao transtorno mental); sensorial e física (deficiência auditiva ou surdez associada à deficiência física; deficiência visual ou cegueira associada à deficiência física); física, psíquica e sensorial (deficiência física associada à deficiência visual ou cegueira e à deficiência intelectual; deficiência física associada à deficiência auditiva ou surdez e à deficiência intelectual; deficiência física associada à deficiência visual ou cegueira e à deficiência auditiva ou surdez).

As crianças com deficiências múltiplas apresentam algumas características que as diferem das outras. Segundo Nascimento (2006, p.11) essas características são: dificuldade na abstração das rotinas diárias, nos gestos ou na comunicação; dificuldades no reconhecimento de pessoas do seu cotidiano; movimentos corporais involuntários; respostas mínimas a estímulos causados por barulhos, toques, entre outros. 
São aspectos comuns em crianças com deficiências múltiplas: aprenderem mais lentamente; tendência a esquecer do que não praticam; terem dificuldade em generalizar habilidades aprendidas separadamente; necessitar instruções organizadas e sistematizadas; necessitar ter alguém que possa mediar seu contato com o meio que o rodeia; apresentar movimentos estereotipados e repetitivos, não demonstrar conhecer as funções dos objetos, não se comunicar da forma convencional, resistir ao contato físico, não reter informações, entre outras características. Dessa forma, trabalhar com pessoas com deficiências múltiplas requer objetivos claros e o compromisso no que se refere à autonomia da criança ou adolescente, seja na escola, na vida diária ou para a inserção no mundo do trabalho.

Para realizar a inclusão efetiva de alunos com deficiências múltiplas, é imprescindível que o educador esteja atento às competências e necessidades deste estudante. É necessário ainda propiciar um ambiente lúdico, buscar atividades adaptadas e funcionais que favoreçam o desenvolvimento da comunicação e das interações sociais dos alunos, respeitando os limites e o tempo de cada educando. Esses fatores podem determinar o êxito na aprendizagem dos alunos com deficiências múltiplas.

As adaptações necessárias ao currículo para promoverem a inclusão de alunos com deficiências múltiplas são de responsabilidade da escola, e envolvem segundo Godoi (2006, p. 34): mobiliário adequado (mesas, cadeiras, triângulo para atividades no solo, equipamentos para atividades em pé e locomoção independente); equipamentos específicos e tecnologia assistida; sistemas alternativos e ampliados de comunicação; adaptação do espaço e eliminação de barreiras arquitetônicas, ambientais, play ground; recursos materiais e didáticos adaptados; recursos humanos especializados ou de apoio; situações diversificadas de aprendizagem e apoio para participação em todas as atividades pedagógicas e recreativas; adaptações de atividades, jogos e brinquedos.

Segundo a autora, os alunos com deficiências múltiplas possuem também potencialidades, possibilidades funcionais e necessidades concretas que necessitam ser compreendidas e consideradas. Apresentam, algumas vezes, interesses inusitados, diferentes níveis de motivação, formas incomuns de agir, comunicar e expressar suas necessidades, desejos e sentimentos (GODOI, 2006, p. 13). 
A inclusão de alunos com deficiências múltiplas na escola para além da aceitação da diversidade humana, implica na transformação significativa de atitudes e posturas, principalmente em relação à prática pedagógica, ao projeto político pedagógico e ao currículo para que estejam em consonância com as necessidades educativas dos alunos, sendo na metodologia de trabalho ou nas formas de avaliação.

\title{
3. A IMPORTÂNCIA DOS JOGOS E DOS RECURSOS LÚDICOS COMO INSTRUMENTOS DIDÁTICO-PEDAGÓGICOS NA INCLUSÃO
}

Os jogos são instrumentos importantes na educação de um modo geral, pois possuem incríveis capacidades educativas, os educandos são atraídos pelo jogo, e consequentemente aprendem através do prazer de jogar ou brincar. $O$ efeito da aplicação de atividades lúdicas, podem ser utilizados na inclusão? Essa interrogação é reflexiva para adaptarmos uma riqueza aplicada no ensino regular, voltada para a inclusão.

\begin{abstract}
Sabemos que a atividade lúdica é importante tanto para o aluno "normal" quanto para os portadores de necessidades especiais, pois a brincadeira é uma ação social do ser humano, brincar durante a infância é algo cultural, no qual todas as crianças devem passar por esse processo de ludicidade, sendo assim através da brincadeira, do jogo, ocorre o processo de inclusão de forma natural, pois no momento da brincadeira as crianças se entregam à ação que está acontecendo, do imaginário, do divertimento e interagem umas com as outras. Com isso, independente da limitação, os educandos especiais também gostam, e participam das atividades lúdicas que o professor desenvolve durante as aulas, sendo assim, nada o impede de interagir durante a brincadeira com os demais colegas de classe, só é necessário fazer algumas adaptações dependendo da limitação do educando para que ele se envolva com mais facilidade nas atividades, sejam elas jogos esportivos, brincadeiras de raciocínio, etc. (SOARES, 2010, p. 19).

$\mathrm{O}$ ato do brincar ou jogar traz muitos benefícios para quem participa dessa atividade, pois, contribui para o desenvolvimento físico, social, intelectual, respeito ao outro, a criança supera os desafios através da brincadeira ou jogo, além disso, os educandos aprendem a serem cooperativos, aprendem regras, a lidar com seus limites, enfim, não é somente uma atividade que proporciona alegria, prazer, divertimento, direta ou diretamente está trabalhando na formação do sujeito, para que ele aprenda a conviver com os outros, a respeitar, a aceitar as pessoas que são diferentes, independente que tenham ou não alguma deficiência. (Ibid, p. 19).
\end{abstract}

O lúdico e os jogos, então podem dinamizar o ensino voltado para a educação especial inclusiva. A potencialização da aprendizagem, se dará pela criatividade do educador, que por sinal deverá apresentar essas ferramentas em uma sequência gradativa de atividades. A tecnologia também pode ser uma grande aliada da inclusão. 
Uma das melhores maneiras de despertar o interesse de uma criança é a partir de jogos. A criança, com toda a sua imaginação e criatividade, é capaz de se deslumbrar com o momento da brincadeira. Porém até neste momento pode haver exclusão, dor e sofrimento, pois as habilidades das crianças são diversificadas, sendo preciso um olhar cuidador para com os grupos, que também é social. O mundo trabalha muito a competitividade desde a infância, o que está presente nos convívios familiares e nos jogos e brincadeiras. Mas é possível alcançar muitos ganhos ao transformar os jogos competitivos em jogos cooperativos. (NASCIMENTO, 2020, p. 55).

\title{
4. A DEFICIÊNCIA INTELECTUAL E AS ALTAS HABILIDADES: ASPECTOS IMPORTANTES
}

A Política Nacional de Educação Especial utiliza um conceito para Deficiência Intelectual (DI), baseado no da Associação Americana de Retardo mental (AARM):

\begin{abstract}
"Esse tipo de deficiência caracteriza-se por registrar um funcionamento intelectual geral significativamente abaixo da média, oriundo do período do desenvolvimento, concomitante com limitações associadas a duas ou mais áreas da conduta adaptativa ou da capacidade do indivíduo em responder adequadamente às demandas da sociedade, nos seguintes aspectos: comunicação, cuidados pessoais, habilidades sociais, desempenho na família e comunidade, independência de locomoção, saúde segurança, desempenho escolar, lazer e trabalho".(BRASIL,1994,p.15).
\end{abstract}

A inteligência é avaliada por meio dos testes de Quociente de Inteligência (QI), aplicados por psicólogos ou psiquiatras, uma pessoa com 75 de QI ou menos é considerada com Deficiência Intelectual.

Nem todas as pessoas com DI se desenvolvem da mesma forma, pois, cada uma possui características individuais, no entanto existe uma classificação de acordo com o nível de comprometimento de cada um.

Figura 1: Classificação da OMS

\begin{tabular}{|lclc|}
\hline \multicolumn{2}{|c}{ Classificação da OMS (Organização Mundial da Saúde) } \\
Coeficiente intelectual & Denominação & Nível cognitivo segundo Piaget & Idade mental correspondente \\
Menor de 20 & Profundo & Periodo Sensório-Motriz & $0-2$ anos \\
Entre 20 e 35 & Agudo grave & Periodo Sensório-Motriz & $0-2$ anos \\
Entre 36 e 51 & Moderado & Periodo Pré-operativo & $2-7$ anos \\
Entre 52 e 67 & Leve & Período das Operações Concretas & $7-12$ anos \\
\hline
\end{tabular}

Fonte: (FIOCRUZ). 
Existem outros instrumentos para avaliar as funções executivas de planejamento, organização, memória operacional, cognição, entre outras, visto que a DI não tem por base apenas o nível de QI. São consideradas como DI: Síndrome de Down; Síndrome do X-frágil; Síndrome de Prader Willi; Síndrome de Angelman; Síndrome de Williams; Erros Inatos do metabolismo.

"Há tantas variações de deficiências intelectuais como fatores de percepção
das relações. O deficiente intelectual nunca pode ser percebido como
deficiente intelectual em geral. (...) são possíveis não um, mas muitos tipos
qualitativamente distintos de deficiência intelectual e que, por último, por
causa da complexidade do intelecto, sua estrutura admite uma ampla
compensação das diversas funções". (VYGOTSKY, 1997 ,p. 24).

Ainda de acordo com Vygotsky (1997, p. 19 ) "o que decide o destino da pessoa, em última instância, não é o defeito em si mesmo, senão suas consequências sociais, sua relação psicossocial”. Quando pensamos em pessoas com potencial elevado na área intelectual ,logo vem à mente indivíduos com Altas Habilidades/Superdotação. Segundo a Política Nacional de Educação Especial na Perspectiva da Educação Inclusiva é definido com características de AH/SD aqueles alunos que:

demonstram potencial elevado em qualquer uma das seguintes áreas, isoladas ou combinadas: intelectual, acadêmica, liderança, psicomotricidade e artes. Também apresentam elevada criatividade, grande envolvimento na aprendizagem e realização de tarefas em áreas de seu interesse (BRASIL, 2008, p. 9).

Esses alunos também são considerados público-alvo da educação especial, pois, necessitam de um olhar atento e acompanhamento do professor e da família para que sejam identificadas suas habilidades. Não é raro que, alunos com AH/SD, sejam considerados como Hiperativos ou Deficientes Intelectuais, sofrendo muitas vezes descrédito do professor, cobranças em excesso, dificuldade de relacionamento com os colegas e até mesmo dificuldades na aprendizagem.

Assim, para que esse aluno obtenha sucesso escolar e as dificuldades que ele encontra na escola sejam excluídas é importante uma formação de professores que saibam diferenciar o aluno com DI, TDAH e AH/SD.

As $\mathrm{AH} / \mathrm{SD}$ podem ser expressadas nas oito inteligências isoladas ou combinadas que foram estudadas por Gardner (2000) que são: lingüística, lógicomatemática, espacial, corporal-cinestésica, naturalista, interpessoal e intrapessoal.

A oferta de um atendimento educacional a alunos com altas habilidades tem sido cada vez mais compreendida como importante fator de estímulo ao desenvolvimento de diferentes capacidades. Esse fato tem como base o reconhecimento de que, por maiores que sejam as habilidades individuais, são necessárias oportunidades de atendimento adequadas para que os 
alunos otimizem plenamente seus potenciais (PEREIRA, GUIMARÃES, 2007, p. 163).

Assim, é necessário que a escola esteja consciente que o Atendimento Educacional Especializado ( $A E E$ ), também deve ser oferecido para esse público e não apenas aqueles que possuem $\mathrm{DI}$ e outros transtornos.

No $A E E$ alunos com $A H / S D$, terão suplementação, enriquecimento de suas aprendizagens, direcionamento para seus interesses específicos e estímulos de suas habilidades e seus potenciais.

$\mathrm{O}$ que distingue uma pessoa talentosa daquela que tem $\mathrm{AH}$, é a intensidade com que desempenha a tarefa que lhe é proposta e não a qualidade do trabalho.

Crianças com Altas Habilidades (AH), fica concentrada durante horas seguidas envolvida na atividade que está fazendo todo o seu tempo, inclusive deixando de fazer seus afazeres. O conceito para altas habilidades inclui capacidade conceitual, abordagem divergente e solução criativa de problemas (VIANA, 2005).

Conforme a definição do Modelo dos Três Anéis idealizada por Renzulli o gráfico a seguir, expressa mais claramente essa concepção de inteligência.

Figura 2: Diagnósticos: Anéis de Renzulli

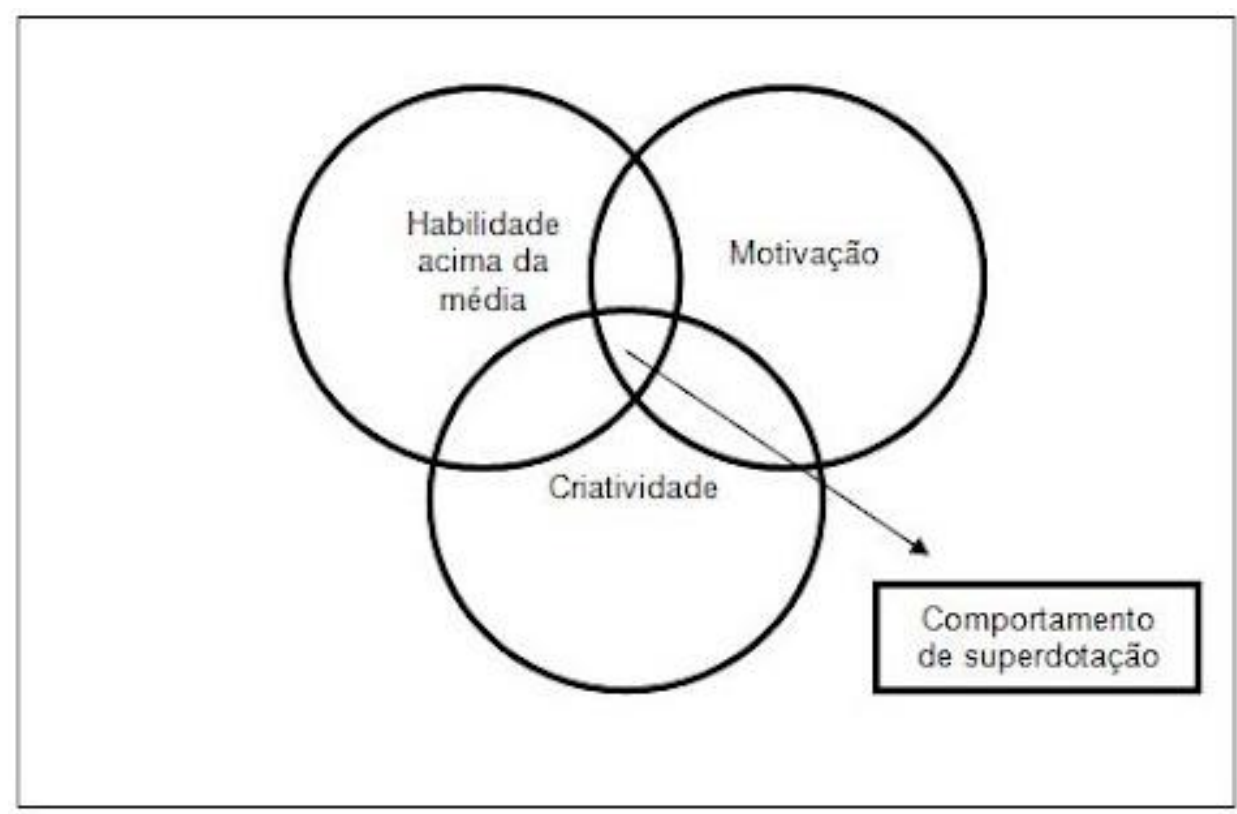

Fonte: (RUSSO, 2015)

Utilizando o Modelo Triádico de Superdotação desenvolvido por Renzulli, indivíduos que apresentam altas habilidades destacam-se por apresentarem um 
conjunto de três traços marcantes que funcionam dinâmica e conjuntamente, como: capacidade acima da média, criatividade em alto nível e envolvimento com a tarefa.

O modelo apresentado pelo teórico teve um grande impacto no âmbito educacional porque apresentava novas formas de identificação e de atendimento para os alunos com indicadores de AH/SD, em qualquer das diferentes áreas de desempenho: matemática, filosofia, religião, ciências da vida, artes visuais, ciências sociais, linguagem, ciências físicas, direito, música e artes performáticas (VIRGOLIM, 2007).

\section{CONSIDERAÇÕES FINAIS}

As reflexões que abrangem a intervenção inclusiva como uma estratégia de não ter um único foco, que é destinado somente para as dificuldades. O intuito de instigar profissionais, para descobrir, estudar e desenvolver novas metodologias, torna a inclusão um processo gradativo de capacitações que vão de encontro com a necessidade escolar, amparando e articulando soluções para desenvolver mediações em diferentes deficiências.

Vale ressaltar, a importância da formação continuada na inclusão, para que as atualizações sejam constantes. O ritmo inclusivo precisa evoluir, as metodologias precisam ser cada vez mais aprimoradas. Os recursos lúdicos, as brincadeiras e jogos, devem ser estruturados e planejados, como um auxílio pedagógico eficiente na condução do processo de ensino e aprendizagem. 


\section{REFERÊNCIAS}

BRASIL. Educação inclusiva: a fundamentação filosófica. Coordenação geral SEESP/MEC; ARANHA, Maria Salete Fábio Aranha (org.). Brasília: Ministério da Educação, Secretaria de Educação Especial, v. 1. 2004. Disponível em: http://portal.mec.gov.br/seesp/arquivos/pdf/fu ndamentacaofilosofica.pdf Acesso em: 10 abr 2021.

.Ministério da educação e do Desporto. Política Nacional de Educação Especial. Brasília, Secretaria da Educação Especial-SEESP,1994.

Política Nacional de Educação Especial na perspectiva da Educação Inclusiva. Ministério da Educação. Secretaria de Educação Especial. Brasília: MEC/SEESP, 2008.

BRIZZOLA, Francélli. Inclusão Escolar de Alunos com Deficiências. Universidade Federal de Pelotas, 2021.

GARDNER, Howard. Inteligência: um conceito reformulado. Rio de Janeiro: Objetiva, 2000.

GODÓI, Ana Maria de. Educação Infantil. Saberes e Práticas da Inclusão: dificuldades acentuadas de aprendizagem: deficiência múltipla. 4.ed. Brasília: MEC, 2006.

LOPES, Marina. Educação Inclusiva é Educação para Todos. 2016. Disponível em: https://porvir.org/educacao-inclusiva-e-educacao-para-todos/ Acesso em: 9 abr. 2021.

NASCIMENTO, Fátima Ali Abdalah Abdel Cader. Educação Infantil. Saberes e Práticas da Inclusão: Dificuldade de comunicação e sinalização: Surdocegueira/ múltipla deficiência sensorial. 4.ed. Brasília: MEC, Secretaria de educação Especial, 2006.

PEREIRA, Vera Lucia Palmeira; GUIMARÃES, Tânia Gonzaga. Programas educacionais para alunos com altas habilidades. In: FLEITH, Denise de Souza. Desenvolvimento de talentos e altas habilidades: orientação a pais e professores. Porto Alegre: Artmed, 2007. cap. 13, p. 163-175.

SILVA, Yara Cristina Romano. Deficiência múltipla: conceito e caracterização. Anais Eletrônico VIIII EPCC - Encontro Internacional de Produção Científica Cesumar. CESUMAR - Centro Universitário de Maringá. Editora CESUMAR Maringá - Paraná, 2011.

VIANA, T. V. Avaliação educacional diagnóstica: uma proposta para identificar altas habilidades. Universidade Federal do Ceará, 2005, 318 fl. Dissertação (Mestrado em Educação) - Departamento de Educação da Universidade Federal do Ceará (UFC), Fortaleza, 2005.

VIRGOLIM, A. M. R. Altas habilidades/Superdotação: encorajando potenciais. Ministério da Educação, Secretaria de Educação Especial, Brasília, 2007.

VYGOTSKY L. S. Fundamentos da Defectologia - Obras Completas - tomo cinco. Cuba: Editorial Puebloy Educación,1997.

FIOCRUZ. Deficiência Mental. http://www.fiocruz.br/biosseguranca/Bis/infantil/deficienciamental.htm

RUSSO, Filipi. Diagnósticos: Anéis de Renzulli, 2015. Disponível em: https://supereficientemental.com/2015/04/25/diagnosticos-aneis-de-renzulli/ Acesso em: 28/04/2021. 
SOARES, Edna Machado. A ludicidade no processo de inclusão de alunos especiais no ambiente educacional (Monografia). Universidade Estadual do Rio de Janeiro, São Gonçalo, RJ. 2010. 33f.

NASCIMENTO, Graciele Seleguim; SCAPIM, Kelly Cristina de Moura; SILVEIRA, Cláudia Alexandra Bolela. Inclusão escolar e jogos cooperativos: uma possibilidade de atuação do psicólogo escolar no processo de socialização e integração. Rev. SPAGESP, Ribeirão Preto, v. 11, n. 2, p. 63, 2010 Disponível em: http://pepsic.bvsalud.org/scielo.php?script=s ci_arttext\&pid=S1677-29702010000200008\&lng=pt\&nrm=iso Acesso em: 28/04/2021. 


\section{CAPÍTULO 04}

A IMPORTÂNCIA DO ATENDIMENTO EDUCACIONAL ESPECIALIZADO (AEE) NO ENSINO REGULAR

\section{Fernando Icaro Jorge Cunha}

Universidade Federal do Pampa - Unipampa

Perfil: http://lattes.cnpq.br/149558185211586

E-mail: icaro729@gmail.com

\section{Maria José Baltar De Azambuja}

Escola Municipal Especial de ensino Fundamental Lygia Morrone Averbuck

Perfil: http://lattes.cnpq.br/8379431150091984

E-mail:mj.azambuja@bol.com.br

\section{Adriana Da Silva Biavaschi}

Universidade Federal do Pampa

Perfil: http://lattes.cnpq.br/6790810594771617

E-mail: fereadri2002@gmail.com

\section{Cristiane De Freitas Rodrigues}

Universidade Federal do Pampa - UNIPAMPA/Campus Uruguaiana

Perfil: http://lattes.cnpq.br/2590473144333273

E-mail: cris_nutri_@hotmail.com

\section{Caroline Pugliero Coelho}

Universidade Federal do Pampa - UNIPAMPA/Campus Uruguaiana

Perfil: http://lattes.cnpq.br/1138015620367845

E-mail: carolinecoelho.aluno@unipampa.edu.br

\section{Letícia Neutzling Benites}

Professora da Rede Municipal de Ensino de Porto Alegre

Perfil: http://lattes.cnpq.br/9538992073439454

E-mail: letizen2003@yahoo.com.br

\section{Luciana Martins Vieira}

Professora da Rede Municipal de Ensino de Porto Alegre

Perfil: http://lattes.cnpq.br/4916051022113025

E-mail: lumartinsv@gmail.com

\section{Janete Hickmann}

Rede de Ensino Municipal de São Leopoldo - RS

Perfil: http://lattes.cnpq.br/0461298984464544

E-mail: janete22h@gmail.com

Resumo: O presente capítulo tem como proposta promover reflexões sobre os avanços observados a partir da implementação do atendimento educacional especializado nas escolas brasileiras para o acompanhamento de estudantes com 
necessidades específicas. Legitimar o acompanhamento, assim como o desenvolvimento de práticas individuais direcionadas para a necessidade do estudante com deficiência, seja ela física ou intelectual, garante meios para uma educação inclusiva, por meio de um ensino progressivo, promovendo um desenvolvimento individual, funcional e prático. Neste contexto, a educação inclusiva apresenta suas individualidades com propostas diversificadas, as quais estarão baseadas nas habilidades de cada aluno, possibilitando compreender melhor as dificuldades de aprendizagem de cada um, as quais valorizem e respeitem as diferenças e ritmos de aprendizagem individuais. O professor especialista que presta o Atendimento Educacional Especializado, faz a ponte entre o aluno e o professor da sala de aula comum, permitindo uma troca de experiência que contribua nesse processo educacional e em todo o contexto escolar, bem como a inserção na sociedade. É importante ressaltar que o atendimento pelo AEE é garantido por lei, mas não é obrigatório, podendo a família optar por não receber $\mathrm{o}$ atendimento $\mathrm{e}$ permanecer apenas na turma regular de ensino. Podemos observar a grande importância e relevância que o Atendimento Educacional Especializado possui dentro da Educação Especial no contexto da Educação Inclusiva. Sempre pensando no respeito às diversidades e na pluralidade que envolve as esferas educativas, lembrando que todos são capazes de aprender quando suas singularidades são respeitadas. Sendo assim, entendemos que os(as) professores(as), tanto do ensino regular quanto do Atendimento Especializado Educacional, precisam trabalhar colaborativamente, oferecendo diversos recursos com intuito de dinamizar o processo de ensino-aprendizagem, compreendendo além disso, a necessidade de se formar um ambiente acolhedor que leve em conta a diversidade dos alunos que irão participar deste processo neste espaço.

Palavras-chave: Ensino básico; Necessidades específicas; Inclusão; Deficiência. 


\section{INTRODUÇÃO}

Antigamente, os alunos com deficiência tinham duas alternativas de provisões escolares frente ao sistema educacional brasileiro, ou faziam parte de uma escola especial filantrópica, que não assegurava a escolarização, ou procuravam uma classe especial nas escolas públicas estaduais, que mais servia como mecanismo de exclusão do que de escolarização. Limitando, rotulando e generalizando as etapas pedagógicas do sistema de educação especial e em que muitas vezes se concentravam na "recuperação ou remediação" de supostas falhas, para a "normalização" do aluno. Desta forma, a escola possuía uma incapacidade em formar processos cognitivos subjacentes de uma propensão de enfatizar supostos prérequisitos das classes especiais (MOREIRA, 2016).

A didática assumia a infantilização do aluno com deficiência, a partir de um raciocínio equivocado que supunha que eles deveriam aprender habilidades típicas do nível pré-escolar, para adquirir "prontidão" para a alfabetização. As estratégias instrucionais se resumiam a treinar os alunos em atividades supostamente preparatórias, com ênfase na repetição. De tal forma, que foi repensado um novo conceito de educação em prol da perspectiva educacional que interage com os objetivos comuns da educação. Considerando assim, que todos terão uma educação com a mesma finalidade, aprenderão as mesmas coisas, mesmo que sejam necessárias estratégias diferentes. Uma vez que, cada aluno requer estratégias pedagógicas individualizadas, não como medidas compensatórias e pontuais, mas sim, como parte de um projeto educativo e social de caráter emancipatório e global (BRASIL, 2001, MOREIRA, 2016).

A inclusão educacional se tornou parte integrante da construção de uma sociedade mais igualitária, reconstruindo sistemas de ensino e organizando-os para dar respostas às necessidades educacionais de todos os alunos (BRASIL, 2001). Com estratégias pedagógicas que priorizem acessibilidade, flexibilidade, equidade e que todos trabalhem de forma colaborativa e personalizada, respeitando a diversidade. Essas práticas devem corresponder a diversos procedimentos, planejamentos e métodos de intervenção dos educadores aos seus alunos em prol da construção do conhecimento (MENDES, 2010). 
Indivíduos com deficiência, sejam elas físicas ou intelectuais, têm o direito de uma educação inclusiva, por meio de um ensino progressivo, promovendo um desenvolvimento individual, funcional e prático. Uma integração suficientemente adequada, que visa a universalização da educação básica e garante uma equidade na educação inclusiva (KASSAR,2009). Para isto existem alguns critérios que devem ser solucionados para implementar um ensino inclusivo, como as práticas devem desenvolvidas individualmente, específicas a cada aluno; as práticas devem ser funcionais, para que os alunos com necessidades especiais possam exercer uma vida com cidadania e social; e as atividades devem ser práticas e colaborativas, os quais observam e avaliam suas limitações e habilidades de cada aluno (CUNHA, 2015).

Neste contexto, a educação inclusiva apresenta suas individualidades com propostas diversificadas, as quais estarão baseadas nas habilidades de cada aluno (MENDES, 2010). Do mesmo modo, que o professor deve conhecer a realidade deste aluno, sua família e sua situação socioeconômica-cultural, para que o professor melhor planeje suas atividades e possibilite $o$ aluno interagir com 0 mundo heterogêneo, o qual ele é inserido. Assim, possibilite compreender melhor as dificuldades de aprendizagem de cada um, proporcionando ações particulares de planejamento, as quais valorizem e respeitem as diferenças e ritmos de aprendizagem de cada um (FLORIAN, 2015).

A formação continuada dos educadores como elemento crucial para a
(re)construção da instituição escolar. Isso implica a construção de espaços
para reflexão crítica, flexibilização e criação de canais de informação nas
escolas, alianças e apoios entre os profissionais e implementação de políticas
públicas de valorização e formação docente. (ALMEIDA, 2004, p.244).

Para melhor entender as peculiaridades de cada aluno com necessidades especiais, é de suma importância que o professor tenha formação específica na educação inclusiva (BRASIL, 2008). Mas, antes disso, o educador/professor deve começar pela humanização, ampliando suas ideias e possibilitando ações que possam transcender do âmbito de sala de aula para a sociedade. Essa afetividade do professor, que faz toda a diferença, para elencar o interesse do aluno com o aprendizado, os quais permitirá ao professor ter êxito na elaboração/reformulação para a aplicação de suas estratégias de ensino (SILVA; ARRUDA, 2014).

Assim, juntamente com afetividade, as práticas lúdicas também irão refletir na construção do conhecimento do aluno com necessidades especiais, mostrando a capacidade de aprender se for corretamente estimulada. Essas estratégias 
pedagógicas adequadas, devem priorizar as habilidades de cada um, e com métodos, técnicas e práticas eficazes irão estimular ainda mais os alunos. Neste caso, o professor junto com toda comunidade escolar consegue exercer o papel da cidadania inclusiva e talvez assim, o diálogo entre a inclusão e o saber possam caminhar juntos na construção de uma educação mais íntegra e homogênea (SASSAKI, 2009).

\section{O QUE É O ATENDIMENTO EDUCACIONAL ESPECIALIZADO?}

Por anos a organização do ensino da educação especial aconteceu de maneira substitutiva ao ensino regular, ou seja, atuou em paralelo. A partir do ano de 2008 , a Política Nacional de Educação Especial na Perspectiva da Educação Inclusiva, afirmou o direito de todos os alunos ao ensino regular, recebendo o atendimento do AEE - Atendimento Educacional Especializado (ALVES; GUARESCHI, 2011).

Segundo Rapoli et al. (2010, p. 17) "o AEE complementa ou suplementa a formação do aluno, visando a sua autonomia na escola e fora dela, constituindo oferta obrigatória pelos sistemas de ensino".

A educação especial é definida pela Política Nacional de Educação Especial na Perspectiva da Educação Inclusiva da seguinte forma:

A educação especial é uma modalidade de ensino que perpassa todos os
níveis, etapas e modalidades, realiza o atendimento educacional
especializado, disponibiliza os recursos e serviços e orienta quanto a sua
utilização no processo de ensino e aprendizagem comum do ensino regular
(BRASIL, 2008, p. 15).

Dentro desta perspectiva a educação especial representa uma modalidade de ensino e não um sistema substitutivo. Ela não deve ser substituída pelo ensino regular, ou vice-versa, ela vem a complementar o ensino de uma forma geral. Alves e Guareschi (2011, p. 34) explicam que "sendo oferecida de forma substitutiva, torna-se incompatível com o princípio de igualdade, porém, se ofertada de forma complementar e/ou suplementar não impede que o aluno frequente o ensino regular". As mesmas autoras também falam sobre a transversalidade da Educação Especial, pois esta modalidade perpassa pelos diversos níveis de ensino, desde a educação básica até o ensino superior.

Fávero, Pantoja e Mantoan (2007, p. 27) apresentam uma interessante forma de compreensão do AEE: 
O Atendimento Educacional Especializado funciona nos moldes similares a outros cursos que complementam os conhecimentos adquiridos, nos níveis do ensino básico e superior, como é o caso dos cursos de línguas, artes, informática e outros. Portanto, esse atendimento não substitui a escola comum para as pessoas com idade de acesso obrigatório ao Ensino Fundamental. [...] e será preferencialmente oferecido nas escolas comuns de ensino regular. Diferente de outros cursos livres, o Atendimento Educacional Especializado é tão importante que é garantido na Constituição Federal.

O público alvo do AEE, conforme a Política Nacional de Educação Especial na Perspectiva da Educação Inclusiva, de janeiro de 2008, são alunos com deficiência, transtornos globais do desenvolvimento e altas habilidades/superdotação. A fim de clarificar em que consiste o AEE, vejamos os objetivos de tal atendimento, conforme conta no artigo $2^{\circ}$ do Decreto 6.571 de 17 de setembro de 2008:

I - promover condições de acesso, participação e aprendizagem no ensino
regular aos alunos referidos no Artigo 10;
II - Garantir a transversalidade das ações da educação especial no ensino
regular;
III - fomentar o desenvolvimento de recursos didáticos e pedagógicos que
eliminem as barreiras no processo de ensino e aprendizagem;
IV - assegurar condições para a continuidade de estudos nos demais níveis
de ensino.

É importante ressaltar que o atendimento pelo AEE é garantido por lei, mas não é obrigatório, podendo a família optar por não receber o atendimento e permanecer apenas na turma regular de ensino. Também é importante salientar que o Atendimento Educacional Especializado deve ser oferecido aos alunos no turno inverso ao das aulas regulares, para facilitar o acesso ao ensino comum. Os atendimentos devem acontecer em uma Sala de Recursos Multifuncionais da própria escola por um professor especializado em AEE, caso a escola não tenha sala ou professor pode ser realizado em outra escola ou em Centros Educacionais Especializados (ALVES; GUARESCHI, 2011).

Ainda sobre o funcionamento do AEE, Alves e Guareschi (2011) explicam que é importante a articulação com as propostas pedagógicas da turma e do professor docente, atuando dessa forma como complemento ao ensino regular. Salientando que essa articulação com o professor regente da turma é de extrema importância, tendo em vista que ambos trabalham com o mesmo aluno e precisam estabelecer objetivos para trabalhar colaborativamente. É necessário que o funcionamento e oferta do $\mathrm{AEE}$ constem "no projeto político Pedagógico da escola, sendo uma ação de toda a comunidade escolar e não uma ação isolada do professor especializado" (ALVES; GUARESCHI, 2011, p. 39). 
Conforme as Diretrizes Operacionais da Educação Especial para o Atendimento Educacional Especializado na Educação Básica, para o professor atuar no AEE precisa "ter formação inicial que o habilite para o exercício da docência e formação específica na educação especial, inicial ou continuada" (BRASIL, 2008, p. 04). No contexto do AEE, o professor pode, além de complementar o ensino regular, ensinar e utilizar recursos como as Tecnologias Assistivas, que, conforme Bersch e Pelosi (2007, p. 08) "são recursos desenvolvidos e disponibilizados às pessoas com deficiência e que visam ampliar suas habilidades no desempenho das funções pretendidas". Ainda, conforme Alves e Guareschi (2011, p. 42) o professor do AEE pode formar parcerias "com áreas intersetoriais, e promover articulação com os serviços de saúde, assistência social, etc., buscando na interdisciplinaridade do trabalho desenvolvido, o apoio para pensar o trabalho educativo".

Podemos observar a grande importância e relevância que o Atendimento Educacional Especializado possui dentro da Educação Especial no contexto da Educação Inclusiva. Sempre pensando no respeito às diversidades e na pluralidade que envolve as esferas educativas, lembrando que todos são capazes de aprender quando suas singularidades são respeitadas.

\section{QUAIS OS TIPOS DE ATENDIMENTO O AEE OFERECE?}

O atendimento educacional especializado - AEE tem como função identificar, elaborar e organizar recursos pedagógicos e de acessibilidade que eliminem as barreiras para a plena participação dos alunos, considerando suas necessidades específicas. O atendimento deve ocorrer nas salas de recursos multifuncionais, nas escolas do ensino regular, em ambientes dotados de equipamentos, mobiliários e materiais didáticos e pedagógicos para a oferta do atendimento educacional especializado às pessoas com deficiência, com transtornos globais do desenvolvimento e com altas habilidades. Esse atendimento deve ocorrer no contraturno escolar, beneficiando o aluno.

O professor especialista que presta o Atendimento Educacional Especializado faz a ponte entre o aluno e o professor da sala de aula comum, permitindo uma troca de experiência que contribua nesse processo educacional e em todo o contexto escolar, bem como a inserção na sociedade. Compete ao profissional que realiza o 
atendimento, identificar as necessidades dos alunos; elaborar plano de atuação de AEE, propondo serviços de acessibilidade ao conhecimento; produzir materiais acessíveis para os alunos; adquirir e identificar materiais de apoio como softwares, recursos e equipamentos tecnológicos, mobiliários, recursos ópticos, dicionários, entre outros; acompanhar o uso dos materiais na sala de aula do ensino regular; orientar professores do ensino regular e famílias dos alunos a utilizar materiais e recursos.

A produção e a distribuição de recursos educacionais para a acessibilidade e aprendizagem devem incluir materiais didáticos e paradidáticos em Braille, áudio e Língua Brasileira de Sinais - LIBRAS, laptops com sintetizador de voz, softwares para comunicação alternativa e outras ajudas técnicas que possibilitam o acesso ao currículo escolar, de acordo com o decreto que regulamenta o Atendimento Educacional Especializado (BRASIL, 2011). O objetivo é garantir recursos de acessibilidade, bem como estratégias de desenvolvimento da aprendizagem, previstos no projeto político-pedagógico da escola.

Com a intenção de complementar as atividades de atendimento educacional especializado, podem ser disponibilizados programas de enriquecimento curricular, o ensino de linguagens e códigos específicos de comunicação, sinalização e tecnologia assistiva. Os alunos poderão necessitar de ajustes nos materiais utilizados, como de um engrossamento de lápis, adaptação de tesoura até um plano inclinado ou um caderno de pauta ampliada. Essas adaptações de recursos ocorrerão de acordo com as necessidades específicas apresentadas pelo aluno, podendo orientar o professor e terapeutas ocupacionais. Ao elaborar um plano de AEE é preciso conhecer o aluno, fazer um estudo de caso, que irá instrumentalizar o professor para que possa entender as dificuldades específicas apresentadas por este, bem como suas áreas de potencialidade. Um estudo de caso estruturado será uma ferramenta valiosa para compor as estratégias de atendimento e enriquecer as aprendizagens deste aluno.

A avaliação também é um instrumento fundamental para identificar as principais características do aluno, seus comportamentos, níveis de desenvolvimento nas áreas cognitiva, linguagem oral e escrita, raciocínio lógico, aprendizagem, desenvolvimento psicomotor, afetivo e interação social. Precisam ser considerados na avaliação, seu desempenho na sala de aula, na sala de recursos e nos demais contextos escolares. 
Somente com tais procedimentos pedagógicos será possível proporcionar o atendimento especializado adequado ao aluno.

A Resolução oㅜ 4, de 2 de outubro de 2009, deixa claro que:

Art. 1 Para a implementação do Decreto n 6.571/2008, os sistemas de ensino devem matricular os alunos com deficiência, transtornos globais do desenvolvimento e altas habilidades/superdotação nas classes comuns do ensino regular e no Atendimento Educacional Especializado (AEE), ofertado em salas de recursos multifuncionais ou em centros de Atendimento Educacional Especializado da rede pública ou de instituições comunitárias, confessionais ou filantrópicas sem fins lucrativos. (BRASIL, 2009, Art 1).

I - Alunos com deficiência: aqueles que têm impedimentos de longo prazo de natureza física, intelectual, mental ou sensorial.

II - Alunos com transtornos globais do desenvolvimento: aqueles que apresentam um quadro de alterações no desenvolvimento neuropsicomotor, comprometimento nas relações sociais, na comunicação ou estereotipias motoras. Incluem-se nessa definição alunos com autismo clássico, síndrome de Asperger, síndrome de Rett, transtorno desintegrativo da infância (psicoses) e transtornos invasivos sem outra especificação.

III - Alunos com altas habilidades/superdotação: aqueles que apresentam um potencial elevado e grande envolvimento com as áreas do conhecimento humano, isoladas ou combinadas: intelectual, liderança, psicomotora, artes e criatividade. (BRASIL, 2009, Art. 4).

\section{O PAPEL DO PROFESSOR DO ATENDIMENTO EDUCACIONAL ESPECIALIZADO}

Os indivíduos com deficiência devem fazer parte da rede regular de ensino, que por sua vez tem como dever atender todo e qualquer aluno, visando proporcionar o ensino segurado pelos Direitos Humanos. A educação com esta metodologia de ensino deve ser constituída de salas de aula preenchidas com alunos normais e com alunos com deficiência, preparando a sociedade para conscientização de que o Plano Nacional de Educação (PNE) tenha oportunidade de cumprir o papel de cidadão, fazendo com que os alunos normais, integrantes da sala de aula sejam conscientizados que a educação é direito de todos, participando do sucesso de superação dos alunos especiais. Este resultado alcançado deve-se ao professor que teve suas habilidades melhoradas para o ensinamento com a igualdade, demonstrando a todos o valor social que cada um possui (BRASIL, 2014).

Nas salas de aula integradas, todas as crianças enriquecem por ter uma oportunidade de aprender uns com os outros, se desenvolvem para cuidar umas das 
outras e conquistem atitudes, as habilidades e valores necessários para as nossas comunidades aprovarem a inclusão de todos os cidadãos.

A inclusão social não é desrespeito a um nível de aprendizado e sim de habilidades sociais e em construção de vida perante a sociedade. Logo, tem-se o início do desenvolvimento intelectual de cada aluno.

A igualdade de todos é o grande destaque para todos os cidadãos, o que resulta no valor social da comunidade, reforçando o respeito entre os direitos humanos, as diferenças, as limitações, tendo como base uma educação protetora de desenvolvimento da evolução.

A inclusão das pessoas especiais nas escolas de rede regular de ensino é um processo de constante evolução, onde toda a comunidade escolar, onde os pais e alunos juntos com suas famílias estão envolvidos diretamente no desenvolvimento e rendimento escolar. A liberdade de manifestação faz com que cada aluno conheça a si próprio e aprenda, em conjunto, seus limites. A adaptação é um aspecto muito importante para este conhecimento, fazendo com que os alunos se relacionem de forma positiva e inclusiva, adquirindo a consciência de que pessoas especiais não oferecem riscos e perigos a ninguém, abolindo a ideia preconceituosa da sociedade de que alunos especiais podem oferecer.

\section{DESAFIOS DO PROFESSOR DO AEE NA ESCOLA DE ENSINO REGULAR}

Um dos maiores objetivos do docente atuante no Atendimento Educacional Especializado é desenvolver oportunidades para a inclusão do estudante com deficiência na convivência escolar e social, alinhando suas metodologias e recursos de ensino às diferentes formas de aprendizagem dos alunos. Nesse sentido, os desafios encontrados pelo professor do AEE na escola de ensino regular são inúmeros, pois ao longo da escolarização discente, diversas barreiras precisam ser derrubadas.

Para Bendinelli (2018), a real efetivação da política de educação inclusiva só acontece quando os professores da classe comum, gestores escolares, professores de AEE e familiares têm a clareza de seus papéis e objetivos. Logo, aponta-se um dos maiores desafios do professor especializado, ou seja, a articulação com todos esses segmentos, "esclarecendo sua função enquanto professor do aluno, bem como 
enquanto parceiro da equipe escolar para trabalhos colaborativos com vistas a planejamentos e avaliações conjuntas do estudante atendido" (BENDINELLI, 2018, on-line).

Nessa perspectiva, é primordial que ocorra um trabalho de cooperação entre os docentes da classe regular e do atendimento educacional especializado, para que ambos utilizem os recursos pedagógicos necessários e apropriados, de acordo com as especificidades inerentes a cada aluno, para que ocorra a efetiva aprendizagem. Nas palavras de Vilaronga (2014, p. 38):

[...] a parceria entre profissionais da educação comum e especial pode ser um dos caminhos, senão o principal deles, para construir salas de aula verdadeiramente inclusivas. Tal parceria, além de contribuir para resolver os problemas de ensino e de aprendizagem em sala de aula, é potente para prover formação continuada permanente, no próprio chão da escola, para todos os profissionais envolvidos.

Contudo, nota-se uma considerável fragilidade quanto aos saberes específicos relacionados à atuação docente com alunos com deficiência na formação inicial de professores regulares, fato que dificulta o desempenho profissional no contexto escolar. "Em outras palavras, muitas vezes a falta de preparo e informação impede o professor de desenvolver uma prática pedagógica sensível às necessidades do aluno especial incluído" (PLETSCH, 2009, p. 148).

Além disso, de acordo com o Decreto № 6571, de 17 de setembro de 2008, "considera-se atendimento educacional especializado o conjunto de atividades, recursos de acessibilidade e pedagógicos organizados institucionalmente, prestado de forma complementar ou suplementar à formação dos alunos no ensino regular" (BRASIL, 2008). Por outro lado, como desenvolver as habilidades e a autonomia dos alunos com deficiência, se ainda existe uma grande carência de recursos e falta de materiais específicos nas instituições públicas de ensino? Este é outro impasse que desafia o dia a dia dos professores do AEE.

As dificuldades ficam ainda mais evidentes se considerarem as limitações do sistema público brasileiro de educação. A inadequação das instalações e dependências de parcela expressiva das escolas, tanto pelo despreparo do docente para lidar com a inclusão escolar quanto pela inexistência de uma prática pedagógica que contemple a diversidade das necessidades dos alunos, além da carência de materiais básicos (livros, etc.) e de recursos tecnológicos avançados e da ausência de equipes de apoio, representam uma pequena amostra das barreiras a serem superadas na escola pública brasileira para que o processo de inclusão escolar de alunos com necessidades especiais se torne uma realidade (GOMES; REY, 2007, p. 414). 
Todavia, é importante ponderar que para muitos profissionais do Atendimento Educacional Especializado os desafios para a inclusão de alunos com deficiência são superados pela capacidade de inovação, pela criatividade e força de vontade. A busca por novos saberes propicia a criação de recursos e metodologias diferenciadas, além de aulas alternativas com materiais de baixo custo. Para tanto, destaca-se a necessidade de investimentos que oportunizem a qualificação e a formação continuada do professor do AEE, bem como, dos demais profissionais da educação, para garantir a efetividade do trabalho pedagógico no ambiente escolar.

\section{OFERTA DO AEE EM CENTROS ESPECIALIZADOS}

O Atendimento Educacional Especializado pode ser ofertado em escolas ou em centros especializados onde muitas vezes contam com equipes multiprofissionais atuando junto aos educandos.

O Ministério da Educação(MEC) através da Resolução ํㅜ 4, de outubro de 2009, instituiu as diretrizes operacionais para o atendimento Educacional especializado (AEE), outorgando que o AEE seja implantado em salas de recursos multifuncionais e em Centros de Atendimento Educacional Especializado(CAEE) da rede pública de ensino ou em instituições comunitárias, confessionais ou filantrópicas sem fins lucrativos, direcionados às pessoas com deficiência, transtornos globais do desenvolvimento ou com altas habilidades/ superdotação.

Os CAEE são espaços físicos criados por cidades vinculadas à Secretaria Municipal de Educação e de Saúde onde neles acontecem os atendimentos educacionais especializados que complementam o atendimento escolar visando oferecer o suporte necessário aos estudantes e suas famílias. Assim como nas escolas, é um serviço de educação inclusiva que identifica, elabora e organiza recursos pedagógicos para este fim.

Destaca-se a relevância das práticas pedagógicas nos Centros de Atendimento Educacional Especializado como uma temática prioritária de investimento. Assim sendo, as práticas pedagógicas tornam-se um dos suportes que contribuem no processo de interação e aprendizagem do aluno, quando aplicadas de forma que atendam as necessidades do aluno e da aluna com deficiência e os resultados apresentados sejam significativos diante da ação pedagógica.( MAIA, 2017, p.71).

São espaços dotados de mobiliário adequado, materiais pedagógicos e didáticos, recursos de acessibilidade e equipamentos específicos para os 
atendimentos aos educandos. A metodologia de ensino aprendizagem aplicada nos centros de atendimento educacional especializado objetiva atender às necessidades específicas dos educandos.

Os profissionais que atuam têm que ser o mediador e a mediadora, buscando sempre fazer a diferença com o diferente em sua prática pedagógica de atendimento. Dessa forma, percebe-se que é necessária uma ação conjunta entre escola, família e poder público a fim de minimizar as dificuldades enfrentadas e garantir o acesso a todos os alunos e todas as alunas, sem exclusão, a educação para uma sociedade igualitária, onde os(as) mesmos(as) saibam conviver e enfrentar as dificuldades como qualquer outro ser humano. (MAIA, 2017, p.71).

A estrutura física deve oferecer um ambiente favorável e adaptado, levando em conta a diversidade do público que receberá, assim como os recursos que precisam ser específicos para atender aos educandos proporcionando um atendimento diferenciado.

Nesse sentido, o CAEE não pode ser confundido com atividade de mera repetição de conteúdos programáticos desenvolvidos na sala de aula regular, mas deve contribuir um conjunto de procedimentos específicos mediadores do processo de apropriação e produção de conhecimento. (MAIA, 2017, p.71).

O trabalho multiprofissional conta com diferentes áreas como fonoaudiologia, fisioterapia, terapia ocupacional, pedagogia, neuropsicopedagogia, psicopedagogia, entre outras. Os municípios têm autonomia para organizar as equipes de profissionais. Uma equipe composta por profissionais de diferentes áreas de atuação tem condições de promover o desenvolvimento do educando de forma mais ampla e completa.

Os Centros de Atendimento Educacional Especializado têm papel fundamental na promoção da inclusão escolar e social dos educandos e famílias que os frequentam, sendo dever do poder público primar por investimentos para qualificar ainda mais estes locais e os profissionais que nele atuam.

\section{CONSIDERAÇÕES FINAIS}

Neste artigo, inicialmente foi problematizada a importância do Atendimento Educacional Especializado (AEE) no ensino regular. Destacou-se que esse atendimento deve ser oferecido em um horário que os alunos não estejam em sala de aula, ou seja, horário alternativo; uma vez que, tem a finalidade de complementar a forma de ensino e não a substituí-lo. Também, salientou que tal atendimento deve ser 
administrado por professores especializados e que as famílias precisam escolher se querem ou não que seus filhos recebam o atendimento.

A forma de se trabalhar com os alunos com necessidades especiais antes da lei sobre Política Nacional de Educação Especial, não era inclusiva. Por isso, a abordagem sobre a AEE se faz necessária para que se possa refletir sobre o modo como as escolas atendem a esses alunos. Os professores tanto do ensino regular quanto do Atendimento Especializado Educacional precisam trabalhar colaborativamente, oferecendo diversos recursos com intuito de dinamizar o processo de ensino-aprendizagem. Há também a necessidade de se formar um ambiente acolhedor que leve em conta a diversidade dos alunos que estarão ali.

Versou-se, em seguida, sobre os tipos de atendimentos, o público-alvo e o papel do professor. Quanto ao atendimento, ficou claro que deve ser de modo a incluir o aluno; por meio de plano de ação, recursos pedagógicos, materiais de apoio como softwares, recursos e equipamentos tecnológicos, mobiliários, recursos ópticos, materiais didáticos e paradidáticos em Braille, áudio e Língua Brasileira de Sinais LIBRAS. O professor especialista em AEE precisa identificar a necessidade de cada aluno e escolher a melhor forma de trabalhá-la. Cabe ao professor, também, garantir a integração desses alunos, saber lidar com as dificuldades, promover um ambiente agradável onde não ocorra o bullying, respeitar as diferenças. Em suma, ser um professor inclusivo.

Verificou-se, ainda, que são muitos os desafios enfrentados pelos professores que recebem alunos com necessidades especiais, um deles é a falta de preparo. Embora haja apoio dos professores especialistas, ainda assim o professor de ensino regular precisa ter habilidade para trabalhar a inclusão. Foi destacado que se não houver uma comunicação aberta entre os professores das disciplinas e o professor da AEE não será possível garantir uma aprendizagem satisfatória.

Enfim, o que se propôs aqui foi um trabalho em conjunto com a educação regular. O aluno com necessidades especiais precisa estar em sala de aula juntamente com todos os outros que não apresentam dificuldades. Porém, em contrapartida deve haver o apoio dos professores especialistas da AEE para que possam auxiliar no ensino-aprendizado. Outro auxílio de fundamental importância relatado neste artigo foi o Centros de Atendimento Educacional Especializado. Tudo 
isso com intuito de promover o melhor atendimento aos alunos que necessitam estar inseridos no ensino regular. 


\section{REFERÊNCIAS}

ALVES, Marcia Doralina; GUARESCHI, Taís. Atendimento Educacional Especializado (AEE). Org. SILUK, Ana Cláudia. Formação de Professores para o Atendimento Educacional Especializado. Santa Maria: UFSM, 2011.

BENDINELLI, Rosana Claudia. Atendimento educacional especializado (AEE): pressupostos e desafios, 2018. Disponível em: <https://diversa.org.br/artigos/atendimentoeducacional-especializado-pressupostos-desafios/>Acesso em: 20/05/2021.

BERSCH, Rita; PELOSI, Miryam Bonadiu. Portal de ajudas técnicas para a educação: equipamentos e material pedagógico especial para educação, capacitação e recreação de pessoas com deficiência física: tecnologia assistiva: recursos de acessibilidade ao computador. Brasília: ABPEE - MEC/SEESP, 2007.

BRASIL, Decreto no 6.571, de 17 de setembro de 2008. Dispõe sobre o atendimento educacional especializado. Brasília: Diário Oficial da União, 2008.

BRASIL, Decreto no 7.611, de 17 de novembro de 2011 - Dispõe sobre a educação especial, o atendimento educacional especializado e dá outras providências, 2011.

BRASIL. Lei Federal 13.005, de 25 de junho de 2014. Aprova o Plano Nacional de Educação - PNE e dá outras providências. Brasília, DF, 25. Jun. 2014. Disponível em: < http://www.planalto.gov.br/ccivil_03/_ato2011-2014/2014/lei//13005.htm>. Acesso em: 17/02/2016.

BRASIL. Ministério da Educação. Diretrizes Operacionais da Educação Especial para o Atendimento Educacional Especializado (AEE) na Educação Básica. Brasília: MEC/SEESP, 2008.

BRASIL. Ministério da Educação. Conselho Nacional de Educação - Câmara de Educação Básica. Resolução no 4, de 2 de outubro de 2009. Institui Diretrizes Operacionais para o Atendimento Educacional Especializado na Educação Básica, modalidade Educação Especial. Disponível em: http://portal.mec.gov.br/dmdocuments/rceb004_09.pdf Acesso em: $31 / 05 / 2021$.

FÁVERO, Eugênia Augusta Gonzaga; PANTOJA, Luísa de Marillac; MANTOAN, Maria Teresa Eglér. Atendimento educacional especializado: aspectos legais e orientações pedagógicas. São Paulo: MEC/SEESP, 2007.

GOMES, Claudia; REY, Fernando Luis Gonzalez. Inclusão escolar: representações compartilhadas de profissionais da educação acerca da inclusão escolar. Psicol. Cienc. Prof., v.27, n.3, p.406-17, 2007.

MAIA, Anaide Costa. Análise das Práticas Pedagógicas Inclusivas do Centro de Atendimento Educacional Especializado "Rosimar Honório Palhiana" do Município de São João de Pirabas-PA. Dissertação (Mestrado Profissional). Faculdade EST. São Leopoldo, p. 90, 2017.

PLETSCH, Márcia Denise. A formação de professores para a educação inclusiva: legislação, diretrizes políticas e resultados de pesquisas. Educar em Revista, Curitiba, n. 33, p. 143-156, 2009. 
VILARONGA, Carla Ariela Rios. Colaboração da Educação Especial em sala de aula: formação nas práticas pedagógicas do coensino. 2014. Tese (Doutorado em Educação Especial) - Centro de Educação e Ciências Humanas, Universidade Federal de São Carlos. São Carlos, 2014. 


\section{CAPÍTULO 05}

POSSÍVEIS ÁREAS DE ESTUDO DA INCLUSÃO ESCOLAR: UMA ABORDAGEM INTRODUTÓRIA

Fernando Icaro Jorge Cunha

Universidade Federal do Pampa - Unipampa

Perfil: http://lattes.cnpq.br/1495581852115865

E-mail: icaro729@gmail.com

\section{Luciana Martins Vieira}

Professora da Rede Municipal de Ensino de Porto Alegre

Perfil: http://lattes.cnpq.br/4916051022113025

E-mail: lumartinsv@gmail.com

Maria José Baltar De Azambuja

Professora da Secretaria Municipal de Porto Alegre-RS

Perfil: http://lattes.cnpq.br/8379431150091984

E-mail:mj.azambuja@bol.com.br

Janete Mendonça Chrispim Maia

Universidade Iguaçu - UNIG

Perfil: http://lattes.cnpq.br/7657514122345716

E-mail: Jmendonca.prof@gmail.com

Márcio Da Mota Machado Filho

Universidade Federal do Pampa - Unipampa

Perfil: http://lattes.cnpq.br/7154020446574377

E-mail: marciotm95@gmail.com

\section{Adriana Da Silva Biavaschi}

Universidade Federal do Pampa

Perfil: http://lattes.cnpq.br/6790810594771617

E-mail: fereadri2002@gmail.com

\section{Cristiane Casagrande Denardin}

Universidade Federal do Pampa - Unipampa

Perfil: http://lattes.cnpq.br/7528612885865102

E-mail: cristianedenardin@unipampa.edu.br

\section{Jean Ramos Boldori}

Universidade Federal do Pampa

Perfil: http://lattes.cnpq.br/7498200773581083

E-mail: jeanboldori.aluno@unipampa.edu.br

Joel De Almeida Nunes

Universidade Luterana do Brasil, ULBRA

Perfil: http://lattes.cnpq.br/0869118201801878 
E-mail: professordematematicams@gmail.com

\author{
Janete Hickmann \\ Rede de Ensino Municipal de São Leopoldo - RS \\ Perfil: http://lattes.cnpq.br/0461298984464544 \\ E-mail: janete22h@gmail.com
}

Resumo: O presente estudo realiza contribuições para com estudos sobre a inclusão no contexto escolar, a partir de reflexões sobre o percurso de diferentes áreas e subáreas vinculadas à pedagogia, buscando compreender aspectos fundamentais da inclusão, entendendo que o diálogo e a interação entre os saberes das áreas promovem um atendimento integral às necessidades individuais, contribuindo assim para que ocorra a inclusão no pleno sentido da palavra. A pedagogia pode efetivamente contribuir para a inclusão que implica em todos os alunos receberem oportunidades educacionais adequadas, que são desafiadoras, porém ajustadas às suas habilidades e necessidades. Já a Psicopedagogia, constitui um conjunto de práticas de intervenção institucionalizadas no campo da aprendizagem, tanto no contexto da prevenção, como no diagnóstico e tratamento das dificuldades de aprendizagem. A Neuropsicopedagogia é uma ciência transdisciplinar, fundamentada nos conhecimentos da neurociência aplicada para a educação e o seu exercício, tanto clínico quanto institucional, deve estar voltado para a educação especial inclusiva, no sentido de entender o funcionamento cerebral, a plasticidade cerebral, os transtornos do neurodesenvolvimento, as síndromes e as metodologias de ensino e aprendizagem. Outra área contribuidora é a neurociência, atuando em sala de aula mediante um aprendizado sistemático e articulado, oferecendo aos professores novas possibilidades para melhorar a sua prática educativa. A psicologia é a ciência que estuda a mente, os processos mentais, as emoções, os comportamentos, sendo seus fundamentos essenciais para o desenvolvimento da inclusão escolar, pois agregam em especificidades encontradas no público-alvo da inclusão. Sendo assim, entendemos que muitas escolas recebem alunos especiais sem ter conhecimento profundo de algumas questões relacionadas aos processos de ensino-aprendizagem dos diferentes, dificultando o progresso devido a falta de profissionais qualificados. Dessa forma, reconhecemos esta temática como relevante por fazer parte de um estudo que vincula aspectos cognitivos, funcionamento do cérebro e de algumas reações nervosas.

Palavras-chave: Pedagogia; Psicopedagogia; Psicologia; Neurociências; Neuropsicopedagogia. 


\title{
1. PEDAGOGIA E A INCLUSÃO
}

O curso de Pedagogia habilita para o exercício da docência na Educação Básica: Educação Infantil, séries iniciais do Ensino Fundamental e formação de professores em nível de Ensino Médio tendo sido instituído instituído pela Legislação em vigor (Diretrizes Curriculares- Resolução CNE/CP n. 1 de 15 de maio de 2006). Pimenta, Franco e Libâneo (2007) assevera no entanto que é próprio da Ciência da Educação o estudo do fenômeno educativo que é um fenômeno multidimensional, a Resolução CNE/CP n. 1 de 15 de maio de 2006 estabelece que:

\begin{abstract}
Art. $2^{\circ}$ As Diretrizes Curriculares para o curso de Pedagogia aplicam-se à formação inicial para o exercício da docência na Educação Infantil e nos anos iniciais do Ensino Fundamental, nos cursos de Ensino Médio, na modalidade Normal, e em cursos de Educação Profissional na área de serviços e apoio escolar, bem como em outras áreas nas quais sejam previstos conhecimentos pedagógicos. $\S 1^{\circ}$ Compreende-se a docência como ação educativa e processo pedagógico metódico e intencional, construído em relações sociais, étnico-raciais e produtivas, as quais influenciam conceitos, princípios e objetivos da Pedagogia, desenvolvendo-se na articulação entre conhecimentos científicos e culturais, valores éticos e estéticos inerentes a processos de aprendizagem, de socialização e de construção do conhecimento, no âmbito do diálogo entre diferentes visões de mundo (BRASIL, 2006, p. 11).
\end{abstract}

Libâneo ampliando a atuação do pedagogo sustenta que a mesma é mais ampliada que a docência, sendo uma Ciência da Educação, pois:

\begin{abstract}
A base de um curso de Pedagogia não pode ser a docência. A base de um curso de pedagogia é o estudo do fenômeno educativo, em sua complexidade, em sua amplitude. Então, podemos dizer: Todo trabalho docente é trabalho pedagógico, mas nem todo trabalho pedagógico é trabalho docente (LIBÂNEO, 2006).
\end{abstract}

Inobstante a centralidade da pedagogia no estudo do fenômeno educativo cabe destacar que outras áreas do conhecimento também se ocupam do fenômeno educativo e da questão do ensino. de sorte que com a complexidade do objeto de estudo da Pedagogia é necessário a participação de outras ciências como ciências auxiliares, possibilitando a interdisciplinaridade entre elas.

Feitas essas breves considerações passamos a apontar as especificidades de uma pedagogia inclusiva, nesse sentido cabe destacar que os movimentos de direitos civis, na década de 1960, nos ensinaram que a discriminação e o preconceito podem "segregar" grupos de indivíduos ou mantê-los participando ativamente na sociedade. Um debate sobre a relação entre deficiências e incapacidade não é apenas primordial, 
como também é interessante e conveniente. A maneira como as pessoas são tratadas pode limitar sua independência e suas oportunidades.

A escola, desde as séries iniciais e educação infantil que são atribuições do pedagogo, pode potencializar a progressiva independência das pessoas viabilizando um conjunto importante de oportunidades que se refletirão na vida adulta.

Nesse sentido a pedagogia pode efetivamente contribuir para a inclusão que implica em todos os alunos receberem oportunidades educacionais adequadas, que são desafiadoras, porém ajustadas às suas habilidades e necessidades; receberem todo o apoio e ajuda de que eles ou os seus professores possam, da mesma forma, necessitar para alcançar sucesso nas suas atividades.

O acesso e permanência a uma educação de qualidade é uma questão de direitos humanos, e as pessoas com deficiências devem fazer parte da escola, que devem modificar seu funcionamento para incluir todos os alunos - esta é a mensagem que foi claramente transmitida pela Conferência Mundial de 1994 da UNESCO sobre Necessidades Educacionais Especiais.

O pedagogo é o profissional que pode contribuir para a efetivação de uma ensino inclusivo articulando uma rede de apoio, que reúna a coordenação de equipes multiprofissionais e de indivíduos que apoiam uns aos outros, através de conexões formais e informais.

Destaca-se também a temática da unidocência da intervenção do pedagogo que potencializa a aprendizagem holística e cooperativa, sem a separação dos componentes de ensino, que está relacionado à criação de uma atmosfera de aprendizagem em sala de aula em que alunos com vários interesses e habilidades possam atingir o seu potencial.

É sabido por vários estudos, que alunos com níveis diferentes de deficiência aprendem mais em ambientes integrados onde lhes são proporcionados experiências e apoio educacionais adequados, sendo o pedagogo um profissional capaz de pensar essas especificidades.

\section{PSICOPEDAGOGIA}

O surgimento da Psicopedagogia ocorreu na Europa por volta do século XX, com o objetivo de diagnosticar e corrigir a inadaptação escolar e social de crianças e 
jovens, trazendo um conceito educacional determinado por uma sociedade estruturada, em que o ser humano deveria se adaptar (MASINI, 2003). No Brasil, a Psicopedagogia irrompeu sob forte influência da Argentina a partir da década de 60, constituindo-se com um enfoque médico-pedagógico. Entretanto, na década de 70, nasceram os primeiros cursos de Psicopedagogia no país, voltados principalmente para complementar a formação do psicólogo e do educador (RAMOS, 2007).

Dessa maneira, a Psicopedagogia emergiu da composição dos saberes da Psicologia e Pedagogia, sendo uma área de estudo multidisciplinar que contribui para explicar e identificar possíveis problemas de aprendizagem, trabalhando na intervenção e superação de tais dificuldades, considerando a atuação de fatores físicos, psicológicos, emocionais, pedagógicos, culturais, sentimentais, sociais etc. "Assim sendo, cabe à Psicopedagogia a lacuna existente entre o Ser aluno e o Ser sujeito" (CARDOZO, 2011, p.29).

Bossa (2008) entende que a Psicopedagogia constitui um conjunto de práticas de intervenção institucionalizadas no campo da aprendizagem, tanto no contexto da prevenção, como no diagnóstico e tratamento das dificuldades de aprendizagem. A Psicopedagogia, portanto, trata-se de um campo que trabalha com os fatores que conduzem e/ou inibem a aprendizagem. "Seus domínios específicos são: o sujeito do conhecimento, o agente de transmissão e as suas dimensões constitutivas; logo, o sujeito-objeto da Psicopedagogia é o ser humano contextualizado em situação de aprendizagem" (BOSSA, 2008, p. 45).

Nas palavras de Masini (2003, p. 02):

Psicopedagogia é concebida como a área que estuda o ato de aprender, entendendo-se 0 ato de aprender como os sentimentos, as ações, as elaborações do sujeito durante o seu processo de aprendizagem e a consciência que ele tem do que realiza. A intervenção psicopedagógica pode ser educacional ou clínica. É educacional quando estuda, analisa e propicia condições para que o aprendiz organize e elabore dados e informações, utilizando-os em sua vida. É clínica quando estuda e analisa bloqueios, para que o aprendiz ultrapasse dificuldades e problemas de aprendizagem e possa organizar e elaborar dados e informações, utilizando-os em sua vida.

Nesse sentido, é fundamental o papel do psicopedagogo no espaço escolar, tanto no trabalho educativo como no desenvolvimento das potencialidades do aluno com deficiência. Para isso, é importante que o trabalho psicopedagógico seja munido de recursos que estimulem a criação e a construção de saberes, como jogos, músicas, livros, brinquedos, etc. Segundo Cardozo (2011, p. 34), "cabe ao psicopedagogo avaliar para além do que é concreto. Visto que a criança muitas vezes não fala sobre 
seus problemas, ou não sabe reconhecê-los, ela utiliza-se de outros meios para expressar-se".

De acordo com Ribeiro (2015, p. 08):

O psicopedagogo tem a finalidade básica em ajudar a promover mudanças, tanto quando intervir diante de problemas que a escola coloca (individuais, de grupo ou metodológicos), como também quando colaborar para melhorar as condições, os recursos e o ensino, realizando a tarefa preventiva que leve a uma diminuição dos problemas que enfrentam. Faz-se urgente que a psicopedagogia irradie o seu diâmetro de ação até as populações de estudantes que, insistentemente, entram em nossas escolas, sem, contudo, lograr aprendizagens capazes de modificar o seu comportamento pessoal e contribuir para modificação de suas condições de vida coletiva.

Além disso, para que o processo de ensino-aprendizagem tenha um resultado positivo, é primordial que haja a contribuição da família. A participação da família é a base para o progresso da criança, e a relação entre a família e a escola promove a interação da criança na sociedade. "O psicopedagogo orienta família e escola pela importância do desempenho de seus papéis, e ainda para a importância da relação entre os agentes para o desenvolvimento da aprendizagem da criança" (BORGES et al., 2015, p. 12025).

Assim, é relevante refletir sobre a importância da atuação de um profissional da Psicopedagogia no contexto escolar, pois de acordo com Claro (2018), essa atuação possui duas linhas, sendo a primeira com o objetivo de integrar o aluno à aprendizagem, conforme os parâmetros da educação formal. A segunda linha está relacionada com a ação conjunta entre pedagogos, professores e orientadores, tendo como pretensão detectar aspectos inibidores do processo de ensino-aprendizagem, para auxiliar o professor na evolução do desenvolvimento dos alunos.

\section{NEUROPSICOPEDAGOGIA}

Há mais de cem anos que os pesquisadores buscam aprimorar seus estudos sobre o cérebro humano, e, atualmente, se pode afirmar que temos excelentes conhecimentos nessa área, a Educação se beneficia dessas descobertas, pois é um campo que lida com as particularidades do cérebro humano, principalmente no que se refere aos estímulos da aprendizagem. São das funções cerebrais que vêm as respostas para muitas indagações da Pedagogia. Por isso, as Neurociências têm muito a acrescentar a diversas áreas do conhecimento, e é dessa fusão que surgiu a Neuropsicopedagogia. (POSFG, 2017). 
Basicamente, Neuropsicopedagogia é uma ciência transdisciplinar, fundamentada nos conhecimentos da neurociência aplicada para a educação, com dispositivos para troca de informações entre a Pedagogia e Psicologia Cognitiva que tem como objeto formal de estudo a relação entre o funcionamento do sistema nervoso e a aprendizagem humana numa perspectiva de reintegração pessoal, social e educacional, conforme aponta o art. 10ำ da resolução 03/2014, da SBNPp (Sociedade Brasileira de Neuropsicopedagogia).

O exercício em neuropsicopedagogia tanto clínica quanto institucional, deve estar voltada para a educação especial inclusiva, no sentido de entender o funcionamento cerebral, a plasticidade cerebral, os transtornos do neurodesenvolvimento, as síndromes e as metodologias de ensino e aprendizagem.

Segundo SBNPp (2015), o PNE (Plano Nacional da Educação), a Legislação da Educação Inclusiva, o ECA (Estatuto da Criança e do Adolescente), dentre outros, devem fazer parte da compreensão do neuropsicopedagogo no sentido de estabelecer diálogos, visando à qualidade educacional e de pertencimento da sua atuação na sociedade como forma de favorecer aqueles alunos em situação de dificuldades e exclusão sociocultural.

O trabalho do neuropsicopedagogo tem por objetivo a prevenção, avaliação, orientação psicológica e acompanhamento aplicados no contexto institucional com vistas à inclusão educacional.

\begin{abstract}
Sua participação na equipe multidisciplinar é fundamental para respaldá-la com conhecimentos e experiências científicas atualizadas na tomada de decisões de base, como a distribuição apropriada de conteúdos programáticos (de acordo com as fases de desenvolvimento humano), seleção de estratégias de manejo de turma, apoio ao professor no trabalho com a heterogeneidade presente na sala de aula, desenvolvimento de técnicas inclusivas para alunos com dificuldades de aprendizagem e/ou comportamentais, programas de desenvolvimento de habilidades sociais e outras questões relevantes no dia a dia da sala de aula, nas quais os fatores psicológicos tenham papel preponderante (CASSINS et al., 2007, p 17).
\end{abstract}

É tarefa do neuropsicopedagogo promover a assessoria de uma educação de qualidade para todos, com foco no trabalho efetivo da educação inclusiva, assim como de prestar o atendimento prioritário às crianças e jovens com dificuldades de aprendizagem em geral.

Em relação a atividade do neuropsicopedagogo clínico, segundo Paín (1992), vale destacar a intervenção com o objetivo de levantar e sistematizar o perfil do aluno no processo de aprender, em detectar os principais pontos de dificuldades e 
necessidades apresentadas pelo educando nos diferentes momentos de sua formação, com a finalidade de identificar o seu desenvolvimento em relação a atenção e as funções executivas de expressão do comportamento, o aspecto da linguagem, a compreensão leitora, a memória dos processos de ensino e aprendizagem, a motivação intrínseca e extrínseca e as próprias estratégias de aprendizagem.

Portanto, a assessoria neuropsicopedagógica, quer seja na equipe gestora de professores quanto para os alunos, tanto institucional quanto clínica, é indispensável para a formação da cidadania crítica destes nos seus diferentes contextos socioculturais, na participação social, na formação ética, além da preparação para o mundo do trabalho, no combate ao fracasso escolar e a elevação da autoestima. (SILVEIRA, 2019).

\section{NEUROCIÊNCIA}

Os estudos na área da neurociências têm sido cada vez mais fomentados na área da educação como uma forma de conhecer melhor o desenvolvimento humano e as habilidades do cérebro.

O interesse pelo cérebro e suas funções não é de hoje, os primeiros experimentos remontam a 4000 anos a.C onde nas civilizações antigas realizavam um procedimento chamado trepanação, que consistia em uma técnica cirúrgica onde se abria um orifício de cerca de 3 centímetros no cérebro de uma pessoa viva com o objetivo de liberar maus espíritos. Contudo, os avanços mais significativos relacionados ao estudo do cérebro se deram no século $\mathrm{xx}$.

Com o surgimento e o desenvolvimento de tecnologias que possibilitaram o estudo das células cerebrais: o microscópio eletrônico e o microelétrodo, que podem registrar as atividades cerebrais de células nervosas individualmente, a tomografia computadorizada axial e a ressonância magnética, que possibilitaram a visualização do sistema nervoso de maneira específica e computadorizada.(MARQUES, p 146-147, 2016).

Esta tentativa de compreender como o sistema nervoso é denominada como neurociência. A neurociência é uma ciência relativamente nova que compreende a química, estrutura e patologia do sistema nervoso. Marques,p.148, 2016 considera que:

A neurociência pode contribuir para a atuação em sala de aula mediante um aprendizado sistemático e articulado e oferece aos professores novas possibilidades para melhorar a sua prática educativa. Considerando que a atual situação educacional pública do país atravessa um período difícil, torna- 
se importante e urgente contemplar as diversas ciências que podem dar alguma contribuição para uma transformação educacional.

Sendo assim, o professor sabendo o modo como o cérebro processa as aprendizagens poderá proporcionar a estimulação pedagógica adequada para que os conhecimentos trabalhados sejam assimilados e o desenvolvimento intelectual da criança ocorra.

Se levarmos em conta que a neurociência realiza estudos cerebrais para obter conhecimentos sobre o modo como pensamos, como agimos, como somos estimulados e, o principal para a educação, compreender a forma como aprendemos e assimilamos informações, poderemos considerar a neurociência como uma ferramenta importante para a construção de métodos e estratégias para uma atuação docente mais eficaz. MARQUES, p. 156, 2016 .

A neurociência tem sido uma aliada muito consistente para exercitar as competências e habilidades dos alunos, adentrando no campo educacional como uma ciência que estuda o campo cognitivo a partir da perspectiva neurobiológica, auxiliando os professores na compreensão do processo de aquisição do conhecimento. Esta parceria busca criar estratégias, condições e um ambiente favorável à aprendizagem.

Um exemplo prático de como a neurociência pode contribuir para o trabalho do professor com alunos com autismo: O professor que se dedicou ao estudo da neurociência conhece o conceito de plasticidade neural ou neuroplasticidade, que consiste na capacidade dos circuitos neurais se moldarem aos estímulos ambientais. Ele sabe que seu aluno com autismo possui seu neurodesenvolvimento determinado por questões genéticas e ambientais, mas que mudanças neuronais podem acontecer se ele proporcionar os estímulos contínuos e adequados a este aluno. Portanto, ele pensará atividades que estimulem este aluno a avançar, pois sabe que seu cérebro tem condições de traçar rotas alternativas para adquirir novos conceitos.

Importante salientar que esta proposta não cria receitas mágicas para o sucesso escolar, mas busca potencializar a prática pedagógica e a reflexão sobre a mesma.

O principal objetivo da neurociência aliada à educação é agregar o conhecimento sobre a funcionalidade do cérebro a favor da criação de várias estratégias educativas que facilitem a aprendizagem. 


\section{PSICOLOGIA}

A psicologia é a ciência que estuda a mente, os processos mentais, as emoções, os comportamentos, dentre outros aspectos que investigam os sentimentos e pensamentos humanos. Os estudos e fundamentos da psicologia são essenciais para o desenvolvimento da inclusão escolar, pois agregam em especificidades encontradas no público-alvo da inclusão.

Conceitos como diferenças individuais e dificuldades de aprendizagem lançam um olhar sobre processos individuais e subjetivos, mas não oferecem esclarecimentos sobre a instituição social da escola. Mas será que não compõe o processo psicológico do estudante o fato de que a escola teria dificuldades de ensinar ou produziria situações de sofrimento psíquico? (DAZZANI, 2010, p. 367).

A psicologia torna-se restrita na educação, quando os seus estudos são direcionados apenas para um atendimento em consultório. É válido entender que muitos estudantes possuem particularidades que precisam ser tratadas em casos particulares, porém o ambiente escolar como um todo, deve utilizar os fundamentos da psicologia no processo de ensino e aprendizagem (DAZZANI, 2010).

O psicólogo escolar, profissional atuante em ambientes educacionais, também teve de redirecionar as suas práticas para as demandas que emergiram desse contexto. A escola regular inclusiva e a sala de aula inclusiva trouxeram desafios aos professores, uma vez que o coletivo e o individual passaram a ganhar notabilidade no cotidiano escolar. Enfatizou-se, assim, a relevância dos professores como público-alvo de atuação do psicólogo escolar (FONSECA; FREITAS; NEGREIROS, 2018, p. 429).

Seria interessante que todas as escolas fossem contempladas com um psicólogo na equipe escolar, para atuar nas necessidades individuais e conjuntas. $\mathrm{Na}$ prática, o professor acaba tendo que lidar com diversas questões que vão além do contexto escolar em sala de aula, utilizando os fundamentos da psicologia para atuar neste processo de equilíbrio

Muitos alunos sofrem com violência, contato direto na comunidade com o uso de drogas, muitos irmãos, falta de alimentação adequada, dentre outros fatores que implicam diretamente no desenvolvimento do processo de ensino e aprendizagem. $O$ professor acaba tendo a necessidade de intervir em um processo humanista e ético, para evitar o bullying.

A carência social, a vulnerabilidade socioeconômica, demonstram a necessidade de um psicólogo atuante no processo de inclusão escolar. Se no ambiente de ensino regular, a atuação do psicólogo e do professor fundamentado na 
psicologia é muito importante, na inclusão escolar real é intensificado a importância desta união em pro do pleno desenvolvimento do educando.

\begin{abstract}
Outrossim, levando em conta, instituições localizadas em áreas periféricas, onde abrange uma comunidade local, enquadrando-se no perfil de vulnerabilidade socioeconômica, a metodologia geralmente adota os fundamentos de psicologia da educação. Neste sentido, o levantamento socioantropológico é essencial para subsidiar e sensibilizar a equipe escolar em geral, para a importância de uma educação igualitária e coesa, protagonizando o educando e garantindo a aprendizagem significativa (DINARDI; CARVALHO; CUNHA, 2021, p. 17).
\end{abstract}

\title{
6. CONSIDERAÇÕES FINAIS
}

Como procuramos destacar neste artigo, algumas áreas de estudo são de suma importância para a inclusão; uma vez que buscam descobrir a melhor forma de trabalhar dificuldades e acessibilidades. Muitas escolas recebem alunos especiais sem ter conhecimento profundo de algumas questões relacionadas aos processos de ensino-aprendizagem dos diferentes, isso dificulta o progresso, porque esses alunos necessitam de profissionais capazes de atendê-los. Dessa forma, entende-se que o tema é relevante por fazer parte de um estudo voltado para aspectos cognitivos, funcionamento do cérebro e de algumas reações nervosas.

Entre os temas abordados está a pedagogia, por se relacionar com uma proposta de estudo que abrange desde as séries iniciais até o ensino médio. $O$ pedagogo precisa ser capaz de atender alunos de várias faixas etárias, entre eles alunos que apresentam alguma necessidade especial. Também vale destacar que é o pedagogo que procura compreender as questões sociais relacionadas ao aluno, ou seja, uma pessoa capacitada para interagir entre alunos, escola e famílias.

Destacou-se, também, a importância da psicopedagogia, área voltada para o estudo da psicologia e da pedagogia, centrada em entender como os alunos aprendem. A contribuição desta área é bastante valiosa. O profissional é capaz de criar diversas atividades inclusivas; verificar quais as dificuldades dos alunos para assim desenvolver propostas de ensino, no intuito de viabilizar o processo de aprendizagem.

Outra questão relevante é o estudo da neuropsicopedagogia que visa dialogar com as outras áreas para buscar entender as necessidades e dificuldades, bem como entender os aspectos da linguagem, compreensão leitora e promover acessibilidade. 
Sendo assim, esse profissional buscará entender como se dá o processo cognitivo e como poderá acompanhar o aluno no contexto educacional.

Verificou-se também que a Neurociência e a Psicologia, voltados para analisar os sistemas mentais do ser humano, podem ser grandes aliados para a inclusão. Visto que a neurociência interessa-se pelo cérebro e suas funções e a psicologia busca entender o comportamento humano. Essas duas áreas juntas poderão possibilitar um melhor atendimento aos alunos que sofrem com alguma dificuldade cognitiva.

Enfim, o que procurou-se destacar neste artigo foram as contribuições de diversas áreas que podem contribuir para o estudo sobre a inclusão. Entende-se que se todas elas dialogarem entre si poderão atender bem aos diferentes, contribuindo assim para haja inclusão no pleno sentido da palavra. 


\section{REFERÊNCIAS}

BRASIL. Resolução CNE/CP 1/2006. Diário Oficial da União, Brasília, 16 de maio de 2006.

BORGES et al. Olhares da Psicopedagogia sobre o desenvolvimento da aprendizagem na educação especial. EDUCERE, XII Congresso Nacional de Educação. PUCPR, 2015.

BOSSA, Nádia Aparecida. A emergência da Psicopedagogia como ciência. Revista Psicopedagogia, v. 25, n. 76, p. 43-48. São Paulo, 2008.

CARDOZO, Aline Souza Moraes Schroeder. A atuação do psicopedagogo na escola inclusiva. Monografia. Universidade Cândido Mendes, Rio de Janeiro, 2011.

CASSINS, Ana Maria et al. Manual de psicologia escolar - educacional. Curitiba: Gráfica e Editora Unificado, 2007.

CLARO, Genoveva Ribas. Fundamentos da Psicopedagogia. Curitiba: InterSaberes, 2018.

FRANCO, Maria Amélia. Pedagogia como ciência da educação. São Paulo: Cortez, $2^{a}$ Ed. 2008.

LIBÂNEO, J.C.; PIMENTA, S. G. Elementos para a formulação de diretrizes curriculares para cursos de pedagogia. Cadernos de Pesquisa, v. 37, n. 130, p. 63-97, jan./abr. 2007

LIBÂNEO, José Carlos. Pedagogia e pedagogos: inquietações e buscas. Educar. n. 17. ,p. 153-176. Editora da UFPR. Curitiba, 2001

MARQUES, Stela. Neurociência e inclusão: implicações educacionais para um processo inclusivo mais eficaz. Disponível em :https://www.researchgate.net/profile/Stela-

Marques/publication/328675727. Acesso em 08 de abril de 2021

MASINI, Elcie Salzano. Psicopedagogia e inclusão: o papel do profissional e da escola.

Revista Psicopedagogia, São Paulo, v.20, n. 61, p 2-6, 2003.

PAÍN, Sara. Diagnóstico e tratamento dos problemas de aprendizagem. [Trad. Ana Maria Netto Machado]. Porto Alegre: Artes Médicas, 1992.

PIMENTA, Selma Garrido [et.al.]. Pedagogia, ciência da educação? São Paulo: Cortez, 1996.

POSFG, Tudo sobre Neuropsicopedagogia Clínica e institucional. 2017. Disponível em: http://posfg.com.br/neuropsicopedagogia-clinica-institucional-hospitalar/ Acesso em: 06 abr. 2021.

RAMOS, Géssica Priscila. Psicopedagogia: aparando arestas pela história. Vidya, Santa Maria, v. 27, n. 1, p. 9-20, jan./jun. 2007.

RIBEIRO, Olbia Cristina. O processo da inclusão escolar e o papel do psicopedagogo na escola. Anais IV Congresso de Psicopedagogia escolar. Universidade Federal de Uberlândia, 2015. 
SAVIANI, Dermeval. Pedagogia: o espaço da Educação na Universidade. Cadernos de Pesquisa, v. 37. N. 130, p. 99-134, jan./abr. 2007.

SILVEIRA, Rafael. O que faz um Neuropsicopedagogo. Cadernos de Estudos e Pesquisa na Educação Básica, Recife, v. 5, 2019.

SOCIEDADE BRASILEIRA DE NEUROPSICOPEDAGOGIA (SBNPp). Neuropsicopedagogo institucional e clínico. 2015. Disponível em .http://www.sbnpp.com.br/neuropsicopedagogoinstitucional-e-clinico-artigocomentado-art-29-do-codigo-de-etica-tecnico-profissional/ Acesso em: 06 abr. 2021.

DAZZANI, Maria Virgínia Machado. A psicologia escolar e a educação inclusiva: Uma leitura crítica. Psicol. cienc. prof., Brasília, v. 30, n. 2, p. 362-375, jun. 2010 . Disponível em $<$ http://pepsic.bvsalud.org/scielo.php?script=sci_arttext\&pid=S141498932010000200011\&lng=pt\&nrm=iso $>$. acessos em 24 maio 2021.

FONSECA, Thaisa da Silva; FREITAS, Camila Siqueira Cronemberger; NEGREIROS, Fauston. Psicologia Escolar e Educação Inclusiva: A Atuação Junto aos Professores. Rev. bras. educ. espec., Bauru, v. 24, n. 3, p. 427-440, set. 2018 . Disponível em <http://www.scielo.br/scielo.php?script=sci_arttext\&pid=S1413 65382018000300427\&lng=pt \&nrm=iso>. acessos em 24 maio 2021. http://dx.doi.org/10.1590/s141365382418000300008 .

DINARDI, Ailton Jesus; CARVALHO, Andriéli Vilanova de; CUNHA, Fernando Icaro Jorge. Social anthropological survey as a school planning tool: An experience of PIBID Sciences of Nature. Research, Society and Development, [S. I.], v. 10, n. 1, p. e22410111705, 2021. DOI: 10.33448/rsd v10i1.11705. Disponível em:<https://rsdjournal.org/index.php/rsd/article/vi ew/11705. Acesso em: 24 may. 2021. 


\section{CAPÍTULO 06}

INCLUSÃO E ENCAMINHAMENTO PARA O MUNDO DO TRABALHO

\section{Fernando Icaro Jorge Cunha}

Universidade Federal do Pampa - Unipampa

Perfil: http://lattes.cnpq.br/149558185211586

E-mail: icaro729@gmail.com

\section{Luciana Martins Vieira}

Professora da Rede Municipal de Ensino de Porto Alegre

Perfil: http://lattes.cnpq.br/4916051022113025

E-mail:Iumartinsv@gmail.com

\section{Maria José Baltar De Azambuja}

Professora da Secretaria Municipal de Porto Alegre-RS

Perfil: http://lattes.cnpq.br/8379431150091984

E-mail:mj.azambuja@bol.com.br

\section{Rejane Marques Alves}

Professora da Rede Municipal de Ensino de Porto Alegre

Perfil: http://lattes.cnpq.br/5724478487166386

E-mail: rejrejmarques@gmail.com

\section{Leonice Aparecida de Fátima Alves Pereira Mourad}

Universidade Federal de Santa Maria - UFSM

Perfil: http://lattes.cnpq.br/7689442989367017

E-mail: profleomourad@gmail.com

\section{Janete Hickmann}

Rede de Ensino Municipal de São Leopoldo - RS

Perfil: http://lattes.cnpq.br/0461298984464544

E-mail: janete22h@gmail.com

Resumo: O presente capítulo traz como foco de abordagem o histórico político e social para a inclusão de pessoas com necessidades especiais no mercado de trabalho, dispondo de discussões e reflexões sobre as potencialidades e fragilidades evidenciadas no passar das décadas e em diferentes perspectivas. Implementar políticas públicas voltadas à inclusão garantem, por exemplo, que as empresas, os cargos públicos e as universidades, tenham vagas destinadas para pessoas com deficiência. As empresas são obrigadas a oferecerem cargos que contemplem a necessidade de o indivíduo atuar no mercado de trabalho, sem que a sua necessidade especial se torne um impedimento. Além disso, as capacitações técnicas e profissionalizantes estão adquirindo novas tendências inclusivas. Aos poucos, o mundo vai agregando valores inclusivos e a pessoa com deficiência adquire maior protagonismo em aplicar seus direitos. A política de cotas é considerada justa quando pessoas com deficiências podem apresentar desvantagens em sua participação na 
sociedade devido às suas limitações, podendo estas serem físicas, sensoriais ou intelectuais. A atuação nas empresas é uma forma dos portadores de deficiência exercerem uma atividade laboral de forma digna. E, de quebra, estabelecerem interatividade a todo tempo com outros profissionais. Trabalho traz aumento da autoestima e independência a todos. Para os deficientes isso é altamente favorável, o que pode ser replicado em outros espaços sociais. É importante ressaltar que a Lei de cotas não garante estabilidade, promoção ou sucesso no trabalho e sim, oportunidade de emprego. Por isso existe uma necessidade constante de aperfeiçoamento e atualização dos profissionais em todos os setores da economia e das tecnologias.

Palavras-chave: Oportunidade; Igualdade; Deficiência. 


\title{
1. INTRODUÇÃO
}

A educação transforma a sociedade, o nível de qualidade da educação reflete diretamente no desenvolvimento dos indivíduos, inserção social, por meio da capacidade crítica e da cidadania. Neste sentido, é possível considerar a importância da inclusão escolar, como ferramenta norteadora da cidadania e do mundo do trabalho.

A Base Nacional Comum Curricular aponta a necessidade de educar para desenvolver o pleno exercício da cidadania e do trabalho. Este contexto é dualista, pois trabalho nesta temática pode estar ligado com emprego, onde a educação precisa preparar o indivíduo, para assumir uma profissão em sociedade, bem como, a produtividade do aluno em sociedade em funções de participação, cooperação e colaboração no meio social em que está inserido (BRASIL, 2018).

\begin{abstract}
A BNCC indica que as decisões pedagógicas devem estar orientadas para o desenvolvimento de competências. Por meio da indicação clara do que os alunos devem "saber" (considerando a constituição de conhecimentos, habilidades, atitudes e valores) e, sobretudo, do que devem "saber fazer" (considerando a mobilização desses conhecimentos, habilidades, atitudes e valores para resolver demandas complexas da vida cotidiana, do pleno exercício da cidadania e do mundo do trabalho), a explicitação das competências oferece referências para o fortalecimento de ações que assegurem as aprendizagens essenciais definidas na BNCC (BRASIL, 2018, p. 13).
\end{abstract}

Na perspectiva da inclusão, a inclusão assume o mesmo papel de garantir que o educando exerça a cidadania, seja diretamente ativo no trabalho social, e preparado para assumir um emprego. Políticas públicas, avanços tecnológicos e o desenvolvimento social, contribuem de fato para que a inclusão seja efetivada no mercado de trabalho.

Desta forma, entendemos o desenvolvimento da Educação Profissionalizante em todos os níveis como um movimento essencial para a qualificação do sujeito com deficiência, promovendo, mais que sua educação, também a possibilidade de seu acesso e permanência no mercado de trabalho. Neste sentido, o acesso representa não só a defesa pela inclusão no mercado de trabalho, mas a possibilidade de este processo permitir a ascensão profissional, para além dos trabalhos primários (PASSERINO; PEREIRA, 2014, p. 832).

Art. 89. A habilitação e a reabilitação profissional e social deverão proporcionar ao beneficiário incapacitado parcial ou totalmente para o trabalho, e às pessoas portadoras de deficiência, os meios para a (re)educação e de (re)adaptação profissional e social indicados para participar do mercado de trabalho e do contexto em que vive. (BRASIL, 1991, Art. 89). 
As cotas inclusivas garantem que as empresas, os cargos públicos e as universidades, tenham vagas destinadas para pessoas com deficiência. As empresas são obrigadas a oferecerem cargos que contemplem a necessidade do indivíduo atuar no mercado de trabalho, sem que a sua necessidade especial se torne impedimento.

Além disso, as capacitações técnicas e profissionalizantes estão adquirindo novas tendências inclusivas. Aos poucos, o mundo vai agregando valores inclusivos, e a pessoa com deficiência adquire maior protagonismo em aplicar seus direitos.

\title{
2. TRABALHO, PESSOA COM DEFICIÊNCIA E INCLUSÃO SOCIAL
}

Art. $2^{\circ}$ Considera-se pessoa com deficiência aquela que tem impedimento de longo prazo de natureza física, mental, intelectual ou sensorial, o qual, em interação com uma ou mais barreiras, pode obstruir sua participação plena e efetiva na sociedade em igualdade de condições com as demais pessoas. (BRASIL, 2015, Art. 2º).

Pessoas com deficiências podem apresentar diferenças físicas, sensoriais ou intelectuais, sendo que tais características podem resultar em restrições em sua participação na sociedade

\begin{abstract}
Entretanto, a condição de deficiência não implica em impossibilidades inalteráveis que determinam para essas pessoas o destino fatal de viverem perpetuamente tuteladas por outrem, sem contribuírem ativa e efetivamente para a sociedade e sem serem protagonistas da própria história. Muitos, tendo oportunidade, trilham com sucesso a carreira acadêmica, ocupam postos de trabalho em diversas áreas, tornam-se artistas ou desportistas talentosos, compram, vendem, etc. além de constituírem família e gerenciarem a própria vida. (BRASIL, 2015).
\end{abstract}

De acordo com Sena (2010), a sociedade democrática é; e tem de ser uma sociedade inclusiva. A incorporação de todas as pessoas, independente de sua origem, poder e riqueza, à estrutura e à dinâmica do sistema político, econômico, social, e cultural, ainda que desempenhando papéis distintos, é nuclear à ideia e à prática da Democracia. Conforme Sena,

No plano da vida econômica e da vida social, essa incorporação tem de se materializar por meio de políticas públicas e normas jurídicas, em face de ser o capitalismo incapaz, pelo exercício e dinâmica de suas meras forças de mercado, de realizar semelhante processo inclusivo. $\mathrm{Na}$ sociedade contemporânea a vasta maioria das pessoas vive de rendimentos propiciados por seu trabalho. Nessa medida, a ordem jurídica trabalhista de cada sociedade e de cada Estado pode cumprir, se bem estruturada, a função decisiva de realizar social e economicamente a democracia, concretizando, em boa medida, seu objetivo de permanente inclusão das correspondentes populações." (2010, p. 19) 
Porém, no Brasil os estereótipos e o preconceito prevalecem e os cargos oferecidos às pessoas com deficiências são pouco atrativos.

A atuação nas empresas é uma forma dos portadores de deficiência exercerem uma atividade laboral de forma digna. E, de quebra, estabelecerem interatividade a todo tempo com outros profissionais. Trabalho traz aumento da autoestima e independência a todos. Para os deficientes isso é altamente favorável, o que pode ser replicado em outros espaços sociais. (SOUZA, 2021).

Contudo, a falta de acessibilidade em transportes, falta de rampas de acesso a prédios quer sejam públicos ou privados, escolas, hotéis, comércio no geral é um entrave para a inclusão social, impede o direito de ir e vir, a autonomia e prejudica a inserção da pessoa com deficiência ao mercado de trabalho.

Desse modo, as pessoas com deficiências são desafiadas diariamente, têm sua vida social dificultada e seus direitos desrespeitados.

Por isso, a Inclusão Social é um objetivo a ser perseguido, é preciso uma maior ação social para a promoção de políticas de Inclusão social, que envolva todas as áreas da sociedade, que visem romper as barreiras do preconceito, para que as pessoas com deficiências possam viver plenamente no ambiente social em que estão inseridos.

\title{
3. INCLUSÃO NO MERCADO DE TRABALHO: LEGISLAÇÃO E DESAFIOS
}

Em julho de 1991, foi sancionada a Lei 8213 que dispõe sobre os mecanismos de previdência social e institui uma cota para inserção de deficiências no mercado de trabalho.

\begin{abstract}
A norma determina que empresas que possuem de 100 a 200 colaboradores devem destinar $2 \%$ das vagas de emprego a portadores de deficiências. Já as organizações que empregam de 201 a 500 pessoas devem conter $3 \%$ de seu quadro de funcionários composto por deficientes. Empresas que tenham entre 501 e 1.000 colaboradores precisam que $4 \%$ de seus funcionários sejam portadores de alguma deficiência física. E por fim, organizações que possuam mais de 1.000 colaboradores devem destinar $5 \%$ de suas vagas a pessoas com deficiência. (MENDONÇA, 2019).
\end{abstract}

As empresas que descumprirem a lei estão sujeitas à autuação por parte da Secretaria Especial de Previdência e Trabalho.

Contudo, percebe-se que a contratação de pessoas com necessidades especiais ainda está muito atrelada ao advento da lei, já que 93\% dos profissionais 
com deficiência com carteira assinada estão empregados em empresas que precisam cumprir esta cota.

Antes da lei de cotas, as pessoas com deficiências ingressavam no mercado de trabalho por meio de ações governamentais e ONGS em órgãos do governo estadual e federal.

Com o passar do tempo, as pessoas com deficiências (PCD) começaram a ter garantidos seus direitos de trabalho pela Constituição Federal de 1988 e leis complementares (Lei. 7.853/89) e normas internacionais (Convenção 159-83 OIT e a Convenção Interamericana Para Eliminação de Todas as Formas de Discriminação Contra Pessoas Portadores da Deficiência (Ministério do Trabalho e Emprego-Brasil, 2007).

A Convenção 159, Organização Internacional do Trabalho (OIT) foi realizada na 69aํ Conferência em Genebra no dia $1^{\circ}$ de junho de 1983 . Essa convenção determinou que todos os países membros deveriam considerar a finalidade da reabilitação profissional e permitir que a pessoa deficiente obtenha e conserve um emprego e progrida e se promova, para que haja a inserção ou a reinserção dessa pessoa na sociedade. (Ministério do Trabalho e Emprego-Brasil, 2007).

A Convenção 159 da OIT de 1983, foi ratificada por meio do Decreto nํㅜ 129, de 18 de maio de 1991, sendo, portanto, a Lei no Brasil desde esta data (Ministério do Trabalho e Emprego-Brasil, 2007).

As pessoas com deficiências são amparadas por lei e todas têm o direito de ingressar no mercado de trabalho sem qualquer forma de preconceito ou distinção.

Entretanto, na maioria das organizações de trabalho brasileiras não é o que ocorre. As organizações que contratam pessoas com deficiências, na maioria das vezes necessitam capacitar os novos funcionários, pois, estes possuem pouca ou nenhuma experiência.

O Instituto Brasileiro dos Direitos da Pessoa com Deficiência, oferece cursos de capacitação técnica que visam a inserção no mercado de trabalho das pessoas com deficiências, mas, mesmo assim, a inserção no mercado de trabalho desse público ainda não é desprovida de preconceito e de falta de conhecimento sobre suas limitações e capacidades.

O Decreto no 914/93, que instituiu a Política Nacional para a Integração da Pessoa portadora de Deficiência, tem como uma de suas diretrizes (art. $5^{\circ}$ ), promover 
medidas que visem à criação de empregos que privilegiem atividades econômicas de absorção de mão-de-obra de pessoas portadoras de deficiência, assim como proporcionar ao portador de deficiência qualificação e incorporação no mercado de trabalho. (BRASIL, 2007).

Atualmente, a política Nacional para integração de pessoas portadoras de deficiência no mercado de trabalho e na sociedade em geral é disciplinada pelo Decreto n. 3.298/99 do Poder Executivo Federal. (BRASIL, 2007).

Em 31 de agosto de 2011, a Presidenta Dilma sancionou a Lei 12.470, que contempla demandas antigas do movimento das pessoas com deficiência. A referida Lei traz alterações substanciais nas regras do Benefício da Prestação Continuada e da Pensão para as pessoas com deficiência.

Assim, passa a haver um incentivo às pessoas excluídas do trabalho, em razão do medo de perder o benefício ou pensão previdenciária.

$\mathrm{Na}$ Consolidação das Leis do Trabalho (CLT), que regulamenta as leis trabalhistas, não existe nenhuma regra especial de trabalho para profissionais deficientes, todos com ou sem deficiência têm os mesmos direitos e deveres, caso contrário o tratamento pode ser considerado discriminatório.

A Declaração Universal de Direitos Humanos, em seu artigo 23, descreve que: "Toda pessoa tem direito ao trabalho, à livre escolha de emprego, a condições justas e favoráveis de trabalho e a proteção contra o desemprego". (DELGADO, 2007).

\section{OFERTA DE VAGAS PARA INCLUSÃO TRABALHISTA E O CAPACITISMO}

O capacitismo nada mais é do que o preconceito, a discriminação e a opressão contra pessoas com qualquer tipo de deficiência. $O$ termo vem do inglês ableism ou disablism, que faz referência à palavra deficiência em inglês (disability).

O capacitismo caracteriza as pessoas com deficiência como inferiores, por causa de sua deficiência. Na visão capacitista, as pessoas com deficiência são incapazes de estudar, trabalhar, se relacionar com outras pessoas e outras tantas coisas naturais às pessoas típicas, ou seja, sem deficiência. (MURÇA, 2020).

O capacitismo pode atingir as pessoas com deficiência de diversas maneiras. Ele vai desde uma agressão verbal ou tratamento de piedade até uma arquitetura inacessível. O capacitismo parte da ideia de que existe um padrão corporal perfeito, a chamada corpo normatividade. As pessoas dentro do padrão socialmente construído de corpo ideal são consideradas "normais". Já 
as pessoas com qualquer tipo de deficiência, que fogem desse padrão, são vistas como "anormais" e exceções. Nessa percepção, a deficiência é vista como uma falha ou algo ruim, que pode ser corrigido ou superado. (MURÇA, 2020).

O capacitismo está ligado à exclusão dos indivíduos com deficiências das instituições escolares e do mercado de trabalho. Segundo o Instituto Brasileiro de Geografia e Estatística (IBGE), o número de pessoas com deficiência no mercado de trabalho não ultrapassa os $0,9 \%$.

"Precisamos entender que a inclusão de pessoas com deficiência é diferente de caridade. É oportunidade porque temos que pensar que esses talentos vão produzir e trazer resultados para os negócios. Não podemos ser contratados como deficiências. Somos talentos e temos muito a somar", enfatiza (CONTRI, 2020, P. 04).

As empresas precisam olhar para as pessoas com deficiências como um sujeito que tem capacidade de exercer uma função de acordo com sua formação profissional e não com sua deficiência.

A lei de cotas não garante estabilidade, promoção ou sucesso no trabalho e sim, oportunidade de emprego. Por isso existe uma necessidade constante de aperfeiçoamento e atualização dos profissionais em todos os setores da economia e das tecnologias.

A falta de inclusão também atinge as instituições educacionais, isso faz com que a educação se torne uma barreira para o mercado de trabalho. Muitas vezes isso acontece por falta de condições financeiras da família, falta de acessibilidade e de programas especializados.

Dessa forma, a grande maioria de pessoas com deficiências só conseguem investir em sua formação acadêmica após conseguir um emprego. Quando esses sujeitos conseguem trabalhar, acionam mecanismos que irão impactar na sua vida e no entorno em que vivem.

Além do trabalho melhorar suas condições financeiras e consequente qualidade de vida, a inserção no mercado de trabalho ainda thes proporciona oportunidades de convívio social, espírito de equipe e um melhor entendimento de como viver em sociedade.

Já para as empresas e para as equipes de trabalho, trabalhar com um funcionário com deficiência, faz com que todos aprendam a conviver com a diversidade. 
Os estabelecimentos que contratam profissionais com deficiência ganham visibilidade e se destacam no mercado internacional. Isso porque existe um número crescente de consumidores com a preocupação de manter relações com empresas politicamente corretas. (CAMARGO, 2018).

\begin{abstract}
Mais que cumprir cotas, a admissão de uma pessoa com deficiência requer uma política verdadeira de inclusão, que deve ser vista como uma oportunidade de aprendizado e enriquecimento de todo o ambiente profissional (CAMARGO, 2018, p. 03).
\end{abstract}

Contudo, para que seja possível a inclusão das pessoas com deficiência no mercado de trabalho é necessário apoio da família e da escola, valorizando e reconhecendo suas competências e principalmente a criação de políticas públicas que promovam a inclusão.

\title{
5. IMPORTÂNCIA DO PROFESSOR DO AEE NA PREPARAÇÃO PARA O MUNDO DO TRABALHO: RELACÃO ENTRE O PLANO DE DESENVOLVIMENTO INDIVIDUÁL E A PREPARAÇÃO PARA O TRABALHO
}

Historicamente as pessoas com deficiência sofrem com a exclusão e o preconceito que impedem o seu acesso ao mercado de trabalho e aos meios de consumo de modo geral. Mesmo com as garantias asseguradas pelas legislações, ainda precisamos avançar mais para que as limitações não sejam tão evidentes e sim as potencialidades que cada um possui.

Sendo assim, o professor do AEE tem um papel fundamental na preparação do aluno para o mercado de trabalho. É ele que pode contemplar em seu PDI (Plano de desenvolvimento Individual) objetivos que visem alcançar a independência e a preparação do aluno para inseri-lo no mundo do trabalho.

$O$ trabalho do professor de AEE neste sentido precisa ir para além dos muros da escola e proporcionar ao aluno experiências para que ele adquira habilidades, competências e saberes para que se torne um cidadão conhecedor de seus direitos.

O papel do professor do AEE é o de articulador destas demandas, assim ele pode providenciar juntamente com os alunos a documentação pessoal desde, como: carteira de identidade, carteira de trabalho, carteira de isenção de passagem no transporte público. Podem, se assim a família consentir, realizar saídas estratégicas da escola com o objetivo de ensinar a este aluno, como se deslocar pela cidade utilizando transporte coletivo. 
No município de Porto Alegre desde 1994 as escolas especiais e de ensino fundamental municipais contam com o Programa de Trabalho Educativo, formalizado pelo decreto $11.484 / 96$, este programa que funciona na modalidade de sala de recursos, orienta, qualifica e encaminha a inserção de jovens e adolescentes com deficiência no mercado de trabalho. Este decreto formalizou as regras para a realização do Programa de Trabalho Educativo PTE, na administração centralizada, autarquias e fundações municipais, além de assegurar direito de recebimento de Vale transporte, bolsa auxílio e tempo limite de participação no programa, tempo este de 2 anos.

O Programa de Trabalho Educativo traz benefícios financeiros e sociais no sentido de proporcionar que os participantes passem a receber seu próprio dinheiro quando iniciam no estágio ou no trabalho, não mais dependendo exclusivamente do BPC ou da renda familiar. Antes disso, ainda no Grupo Operativo já se observa que os alunos são beneficiados com o aumento da autoestima e autonomia, com a socialização com os grupos de outras escolas e com os aprendizados sobre o mundo do trabalho. (MILLANI, 2019).

Este programa é apenas um exemplo do que é possível fazer nas escolas para promover a inclusão dos alunos com deficiência no mundo do trabalho. Mas é preciso mais, precisamos dissipar a visão de que inclusão é feita em todos os âmbitos da sociedade, e compreender que além de alunos, as pessoas com deficiência, são filhos, irmãos, pais e acima de tudo cidadãos. 


\section{REFERÊNCIAS}

BRASIL. Lei no 13.146, de 6 de julho de 2015. Institui a Lei Brasileira de Inclusão da Pessoa com Deficiência (Estatuto da Pessoa com Deficiência), 2015. Disponível em:

http://www.planalto.gov.br/ccivil_03/_ato2015-2018/2015/lei/l13146.htm Acesso em:

23/05/2021.

BRASIL. Lei no 8213/91, de 2 de julho de 1991. Dispõe sobre os Planos de Benefícios da Previdência Social e dá outras providências, 1991. Disponível em:

https://www2.camara.leg.br/legin/fed/lei/1991/lei-8213-24-julho-1991-363650-

publicacaooriginal-1-pl.html Acesso em: 23/05/2021.

BRASIL, Ministério da Educação. Instituto Federal da Paraíba, 2015. Disponível em: https://www.ifpb.edu.br/assuntos/fique-por-dentro/a-inclusao-social-de-pessoas-comdeficiencia Acesso em: 11 abr. 2021.

BRASIL. Ministério da Educação. Base Nacional Comum Curricular. Brasília, 2018.

Ministério do Trabalho e Emprego. 2007. Disponível em:

http://www.trabalho.gov.br/ Acesso em: 11 abr. 2021.

CAMARGO, Marcelo. Direitos das Pessoas com Deficiências. 2018. Disponível em: https://folhadirigida.com.br/mais/noticias/especiais/direito-das-pessoas-com-deficiencia-nomercado-de-trabalho Acesso em: 24 abr. 2021.

CONTRI, Tabata. Futuro do mercado de Trabalho. 2020. Disponível em:

https://www.cpb.org.br/noticia/detalhe/3121/futuro-do-mercado-de-trabalho-para-pessoascom-deficiencia-gera-expectativas-para-efetiva-inclusao Acesso em: 24 abr. 2021.

DELGADO, Mauricio Godinho. Curso de direito do trabalho. 6. Ed. São Paulo: LTR, 2007.

MENDONÇA, Ana. A inclusão de pessoas com deficiências no mercado de trabalho. 2019. Disponível em: https://www.colab.re/conteudo/pcd-no-mercado-de-trabalho Acesso em 22 abr. 2021.

MILLANI, Luiza Saraiva. Inclusão para além da escola: Conhecendo o Programa de Trabalho Educativo. Trabalho de Conclusão de Curso. Porto Alegre, 2019.Disponível em:https://lume.ufrgs.br/handle/10183/206861. Acesso em 22 de abril de 2021.

MURÇA, Giovana. Capacitismo. 2020. Disponível em:

https://querobolsa.com.br/revista/atualidades-enem-capacitismo Acesso em 24 abr. 2021.

SENA, Adriana G. de; DELGADO, Gabriela N.; NUNES, Raquel P. Dignidade humana e inclusão social : caminhos para a efetividade do direito do trabalho no Brasil. São Paulo: LTr, 2010.

SOUZA, Bruno Carvalho. A Inclusão de Pessoas com Deficiências e sua Inserção na Sociedade. 2021. Disponível em: https://fce.edu.br/blog/a-inclusao-de-pessoas-comdeficiencia-e-sua-importancia-para-a-sociedade/ Acesso em: 11 abr. 2021.

PASSERINO, Liliana Maria; PEREIRA, Ana Cristina Cypriano. Educação, inclusão e trabalho: um debate necessário. Educ. Real., Porto Alegre v. 39, n3, pág. 831 846, setemb ro de 2014. Disponível em <http://www.scielo.br/scielo.php?script=sci_arttext\&pid=S2175 62 
362014000300011 \&lng=en\&nrm=iso $>$. acesso em 23 de maio de 2021. https://doi.org/10.1590/S2175-62362014000300011 . 


\section{CAPÍTULO 07}

\section{PRÁTICAS INOVADORAS EM EDUCAÇÃO ESPECIAL E INCLUSIVA}

Cristiane De Freitas Rodrigues

Universidade Federal do Pampa - Unipampa/Campus Uruguaiana

Perfil: http://lattes.cnpq.br/2590473144333273

E-mail: cris_nutri_@hotmail.com

Fernando Icaro Jorge Cunha

Universidade Federal do Pampa - Unipampa

Perfil: http://lattes.cnpq.br/149558185211586

E-mail: icaro729@gmail.com

\section{Luciana Martins Vieira}

Professora da Rede Municipal de Ensino de Porto Alegre

Perfil: http://lattes.cnpq.br/4916051022113025

E-mail: lumartins@gmail.com

\section{Maria José Baltar De Azambuja}

Professora da Secretaria Municipal de Porto Alegre-RS

Perfil: http://lattes.cnpq.br/8379431150091984

E-mail:mj.azambuja@bol.com.br

\section{Rita Freitas Ribeiro Pessano}

Secretaria Estadual e Municipal de Educaçã/Uruguaiana-RS

Perfil: http://lattes.cnpq.br/4276364637043779

E-mail:ritapessano1982@gmail.com

\section{Cristiane Casagrande Denardin}

Universidade Federal do Pampa - Unipampa

Perfil: http://lattes.cnpq.br/7528612885865102

E-mail: cristianedenardin@unipampa.edu.br

\section{Jean Ramos Boldori}

Universidade Federal do Pampa

Perfil: http://lattes.cnpq.br/7498200773581083

E-mail: jeanboldori.aluno@unipampa.edu.br

\section{Márcio Da Mota Machado Filho}

Universidade Federal do Pampa - Unipampa

Perfil: http://lattes.cnpq.br/7154020446574377

E-mail:marciotm95@gmail.com

\section{Osmar Senador Mendonça Júnior}

Escola Estadual de Ensino Fundamental Santa Inês - Alegrete/RS

Perfil: http://lattes.cnpq.br/8616680212649832 
E-mail: jrbiol1507@gmail.com

Janete Hickmann

Rede de Ensino Municipal de São Leopoldo - RS

Perfil: http://lattes.cnpq.br/0461298984464544

E-mail: janete22h@gmail.com

Gabriel Ferraz Martins

Universidade Federal do Rio de Janeiro - UFRJ

Perfil: http://lattes.cnpq.br/8170278356375873

E-mail: gabrielferrazmtrs@gmail.com

Resumo: $O$ processo educativo precisa acompanhar as novas tendências que surgem, na medida em que a Educação evolui em amplas dimensões. O objetivo deste artigo é discutir sobre o contexto das práticas inovadoras em Educação Especial e Inclusiva. Neste sentido, os autores foram submetidos a apontar levantamentos pedagógicos que permeiam metodologias eficazes, que redimensionam a práxis pedagógica e contribuem para a formação de uma prática inclusiva, sobretudo no tocante à necessidade de intervenção frente ao diagnóstico de educandos portadores de necessidades educacionais especiais. Compreende-se que o planejamento e a organização docentes devem estar pautados em atividades que venham de encontro com os níveis específicos, e que o processo torna-se ainda mais dinâmico quando todos os alunos são levados a participar desta inclusão, quando a gestão passa a buscar subsídios para auxiliar os docentes, e os avanços educativos surgem naturalmente na vida do educando, como produto de uma aprendizagem verdadeiramente significativa.

Palavras-chave: Práticas inovadoras; Inclusão; Inovação; Metodologias ativas. 


\section{INTRODUÇÃO}

O presente artigo visa trazer a conhecimento algumas das práticas inovadoras que podem ser utilizadas na Educação Especial e Inclusiva, auxiliando os/as professores/as que trabalham nesse contexto escolar. A Educação Especial e Inclusiva vem sendo debatida desde a sua citação na Lei de Diretrizes e Bases da

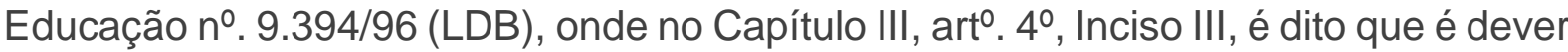
do Estado garantir o atendimento educacional especializado, de forma gratuita e na rede regular de ensino, para os/as alunos/as com necessidades educativas especiais (BRASIL, 1996).

Mesmo transcorrido tanto tempo desde sua aplicação, ainda encontramos muitas dificuldades na oferta de um atendimento significativo e que realmente se atém às necessidades educacionais desses/as alunos/as, principalmente no ensino regular. Trabalhar na escola as diversas necessidades educacionais dos/as alunos/as é ainda uma dificuldade muito grande para uma considerável parcela dos/as professores/as da rede regular de ensino, visto que a qualificação necessária para atendimento aos alunos/as com necessidades educativas especiais não ocorreu durante a sua graduação.

O estudo para qualificar o conhecimento dos/as professores/as nesta temática é algo recente, que foi proporcionado por leis que garantem o direito à qualidade nesse atendimento educacional. Nisso reside a necessidade de trazer esse tema para discussão e conhecimento de todos os segmentos escolares, principalmente para os/as professores/as, que atendem diariamente esses/as alunos/as.

A busca por metodologias que tornam esses/as alunos/as com necessidades educativas especiais, mais participativos, socializados e protagonistas nas aulas, torna esse tema muito importante para que ocorra de fato a inclusão desses indivíduos em todos os âmbitos sociais.

\section{INOVAÇÃO PEDAGÓGICA}

Tem se tornado lugar comum entre os profissionais da Educação o diagnóstico de que o modelo educacional vigente não dá conta das novas demandas sociais. 
Um dos problemas, já bastante evidenciado, é que o modelo tradicional de educação, centrado na figura do professor, onde o estudante é visto como receptor dos conteúdos e que basta ouvir e manter a atenção para aprender passivamente, não é eficiente para garantir a aprendizagem.

Mas, o que significa inovar? De acordo com o dicionário online de Português, "inovar" é "realizar algo novo ou que nunca havia sido feito antes; produzir novidades" (INOVAR, 2021).

Por isso, "quando falamos em inovação pedagógica, nos referimos justamente a inovações que tragam melhorias e gerem valor para o processo de aprendizagem em si." (ALMEIDA, 2017). Para tanto, não basta apenas equipar as escolas com internet wi-fi, lousas eletrônicas e computadores; essas iniciativas não operam a mudança necessária nos professores, tampouco nos alunos. É preciso promover inovações pedagógicas que motivem, empoderem e engajem professores e alunos no processo de ensino-aprendizagem.

A inovação pedagógica pode ser definida como a invenção/criação de melhorias e/ou transformações do processo de aprendizagem, que gerem valor para estudantes, professores e sociedade como um todo. (ALMEIDA, 2017).

Deve-se destacar ainda que promover tais melhorias só é eficaz se mudarmos também a lógica do processo educacional, pois de nada adiantará incrementar as aulas com recursos e técnicas inovadoras se, ao final do mês ou semestre, o professor está preocupado apenas que os alunos assimilem conhecimento para realizarem uma prova e atribuir-lhes uma nota.

Porque, inventar/criar elementos que tragam novos valores para a
aprendizagem significa que estamos deslocando o foco da educação para o
que realmente importa: os alunos não se sentirão motivados a estudar por
causa da prova, ou para obter seus diplomas, mas sim porque enxergam
valor naquilo estão aprendendo; não irão dedicar tempo às tarefas e projetos
por estarem sendo obrigados a isso por seus professores e familiares, mas
sim porque estarão enxergando significado e sentido em tudo o que
aprendem. (ALMEIDA, 2017).

Professores inovadores conseguem perceber no cotidiano o que fará a diferença em suas aulas, utilizando-o para atingir seus objetivos pedagógicos. Quadro e giz não são suficientes para trabalhar com alunos que têm na palma da mão seus smartphones com acesso à internet 24 horas por dia, nos 7 dias da semana.

A inovação pedagógica tem o potencial de tornar o processo de ensinoaprendizagem mais inclusivo, rico, flexível, diverso e atual para envolver a todos neste 
processo, inclusive os que possuem maiores dificuldades, e que necessitam do olhar diferenciado do professor.

\section{TECNOLOGIAS E MÉTODOS ATIVOS}

Quando os alunos vivenciam métodos ativos, melhoram a socialização, a comunicação oral, a escrita e a autonomia. As metodologias ativas (MA) apresentamse como um instrumento para a construção do conhecimento usando procedimentos

analíticos e dialógicos. É uma concepção educativa que estimula processos de ensino-aprendizagem crítico-reflexivos pautados na prática e na experiência, em que o educando participa e se compromete ativamente com seu aprendizado (AMARAL, 2017).

São estratégias de ensino centradas no aluno, na participação dos mesmos e na construção de suas aprendizagens em um mundo conectado e digital, cuja implantação requer uma análise do currículo que se pretende trabalhar para a formação do aluno, enfatizando tanto os conhecimentos específicos como a colaboração, interdisciplinaridade, habilidade para inovação, trabalho em grupo e educação para o desenvolvimento sustentável, regional e globalizado (AMARAL, 2017).

Aprendizagem baseada em projetos, aprendizagem baseada em problemas, estudos de caso, aprendizagem por pares ou times, sala de aula invertida e gamificação são alguns exemplos de métodos ativos de aprendizagem.

As MA são muito importantes no ensino inclusivo, pois os alunos atualmente encontram-se imersos em uma cultura digital e em se tratando de alunos com deficiências, a combinação desses métodos com a tecnologia, particularmente a assistiva, contribui para a promoção de suas competências e habilidades.

A Lei 13.146/16 - Lei Brasileira de Inclusão da Pessoa com Deficiência (Estatuto da Pessoa com Deficiência) é destinada a assegurar e a promover, em condições de igualdade, o exercício dos direitos e das liberdades fundamentais por pessoas com deficiência. Nela é prevista a aplicação das tecnologias assistivas, que podem envolver recursos digitais, mas não só.

De acordo com a definição proposta pelo Comitê de Ajudas Técnicas (CAT), tecnologia assistiva "é uma área do conhecimento" de característica interdisciplinar, que engloba produtos, recursos, metodologias, estratégias, práticas e serviços que 
objetivam promover a funcionalidade, relacionada à atividade e participação, de pessoas com deficiência, incapacidades ou mobilidade reduzida, visando sua autonomia, independência, qualidade de vida e inclusão social (BRASIL, 2009).

Como bem afirma Radabaugh (1993): "Para as pessoas sem deficiência, a tecnologia torna as coisas mais fáceis. Para as pessoas com deficiência, a tecnologia torna as coisas possíveis.".

No tocante à ferramentas digitais, vale destacar que existem recursos tecnológicos básicos que podem ser mobilizados pelo professor e utilizados para auxiliar no processo educativo de alunos com necessidades educacionais especiais: tais como os recursos de Narrador, Lupa e Alto Contraste, que existem em todas as versões do sistema operacional Windows e uma vez utilizados para auxiliar alunos com problemas de visão, tornam-se tecnologia assistiva; ou ainda softwares especialmente desenvolvidos para isso, como o DOSVOX, um sistema que permite que pessoas com deficiência visual utilizem autonomamente um computador comum para desempenhar suas tarefas (NÚCLEO PEDAGÓGICO DERAME, 2020).

As tecnologias digitais e as metodologias ativas são ferramentas que proporcionam a adequação necessária do processo pedagógico às necessidades dos alunos nativos digitais. Estas adequações podem ser direcionadas à personalização, à colaboração e à autonomia. Porém, deve-se destacar que não se pode admitir a manutenção de um modelo tradicional e acreditar que pequenos ajustes amenizarão ou resolverão determinadas problemáticas presentes na escola e sua relação com a tecnologia (MORAN, 2017).

Na utilização das tecnologias, o professor deve ter ciência de que não é o detentor do saber e que seu papel deve ser o de um mediador do conhecimento do aluno. Assim, o processo de aprendizagem é verdadeiramente favorecido pelo uso de recursos tecnológicos.

A conjunção entre métodos ativos e tecnologia proporciona meios para práticas inclusivas e uma educação de qualidade. Não se pode esquecer que, para muitas pessoas, esses recursos técnicos e tecnológicos e, em especial, as Tecnologias de Informação e Comunicação (TIC's), constituem a via de acesso ao mundo, à interação social e à comunicação ambiente (GONZÁLEZ, 2002).

A utilização das diferentes estratégias e recursos tecnológicos permite atenuar as dificuldades que alguns sujeitos com necessidades educativas especiais têm não 
só durante o período de escolarização, como em sua posterior incorporação ao mundo do trabalho (GONZÁLEZ, 2002).

\section{METODOLOGIAS ATIVAS PARA UMA EDUCAÇÃO INCLUSIVA}

As metodologias ativas podem ser grandes aliadas da Educação Inclusiva, por favorecerem um aprendizado autônomo, participativo, colaborativo e significativo. Queremos abordar aqui alguns métodos que podem ser trabalhados pelo professor no sentido de promover uma educação mais inovadora e inclusiva.

Desde já, vale alertar que não se deve olhar para os métodos ativos como uma "receita de bolo", uma fórmula fechada, a ser seguida com exatidão $(\mathrm{BACICH}$; MORAN, 2018).

Assim como cada contexto escolar apresenta uma realidade diferente, 0 professor precisará desenvolver o seu olhar criativo na escolha e uso das metodologias ativas, avaliando o impacto desses métodos sobre as pessoas com necessidades educacionais especiais. A seleção crítica dos métodos e sua adaptação são caminhos necessários, assim como a combinação de metodologias e sua reinvenção é incentivada e pode gerar excelentes resultados. As metodologias ativas são um campo aberto para a criação. Os princípios das metodologias ativas é que não podem deixar de ser observados, como a ideia de que o professor deve atuar como um mediador do processo de aprendizagem, e de que o aluno deve ser conduzido a uma aprendizagem autônoma, onde ele se torna protagonista de seu próprio aprendizado.

A reflexão crítica sobre a prática pedagógica é um imperativo para o professor, o fator que permite a evolução do ato pedagógico frente a percalços e novos desafios. Cabe ao professor reavaliar e reinventar o uso das metodologias ativas de acordo com a conveniência a fim de alcançar seus objetivos pedagógicos, sempre levando em conta o contexto, os recursos disponíveis, o público alvo e as diferentes necessidades educacionais em perspectiva.

Nas metodologias ativas, não só o aluno assume postura ativa, como o professor também é ativo enquanto autor criativo de suas aulas e orientador de processos de aprendizagem. Por isso, é extremamente importante que o professor planeje bem o uso das metodologias ativas, fazendo uma boa e criativa seleção de 
métodos e de materiais que despertem o interesse do aluno, exercendo uma escuta ativa no sentido de conhecer as demandas mais específicas dos alunos (sensibilidade essencial, sobretudo no tocante a alunos com necessidades educacionais especiais), bem como promovendo feedbacks especializados sobre as atividades propostas, a fim de obter retorno sobre a retenção de conhecimento por parte dos alunos e conhecer se a sua solução de aprendizagem necessitará de ajustes ou mesmo precisará ser completamente refeita.

\subsection{Aprendizagem Baseada em Projetos e Aprendizagem Baseada em} Problemas

A aprendizagem baseada em problemas é uma metodologia ativa de aprendizagem que consiste em organizar os alunos em torno da resolução de problemas concretos. Tem como características principais: (1) o fato de envolver os alunos coletivamente na resolução de problemas; (2) tomar como objeto de estudo problemas do mundo real, permitindo ao estudante aprender de forma significativa e sintonizada com sua realidade; e (3) criar um ambiente de aprendizagem no qual os professores atuam como mediadores do conhecimento (RANGEL; GUIMARÃES, 2020).

Todo o processo é organizado em três fases. Na primeira fase, os alunos têm contato com o problema, formulam hipóteses e se organizam para um estudo dirigido. $\mathrm{Na}$ segunda fase, os alunos realizam, de forma individual, esse estudo, definindo algumas estratégias para o problema. Na terceira fase, os alunos se reúnem e cada um apresenta ao grupo suas propostas, sendo feita, então, a discussão e avaliação coletiva das propostas, a fim de que os integrantes de cada grupo cheguem a uma solução conjunta para o problema (RANGEL; GUIMARÃES, 2020).

A aprendizagem baseada em projetos é uma metodologia de aprendizagem em que os alunos também trabalham de forma colaborativa e se envolvem com a resolução de um problema ligado ao mundo real, com fases e momentos em que o aluno age sozinho e em equipe. Contudo, na aprendizagem baseada em projetos, o aluno é levado a desenvolver um projeto, que normalmente é um produto, que pode ser um site, um blog, um brinquedo, uma apresentação multimídia em torno de um problema etc. Os projetos podem ter variada natureza: 
“- Projeto construtivo: a finalidade é construir algo novo, criativo, no processo e/ou no resultado.

- Projeto investigativo: o foco é pesquisar uma questão ou situação, utilizando técnicas de pesquisa científica.

- Projeto explicativo: procura responder questões do tipo: 'Como funciona? Para que serve? Como foi construído?'. Busca explicar, ilustrar, revelar os princípios científicos de funcionamento de objetos, mecanismos, sistemas etc." (BACICH; MORAN, 2018).

São metodologias cujo valor para a Educação Inclusiva está no caráter colaborativo e no fato de promoverem diálogos e a integração entre os alunos (RANGEL; GUIMARÃES, 2020). Podem ser convenientemente utilizadas para discutir colaborativamente problemas e propor soluções relacionadas ao universo das pessoas com necessidades educacionais especiais, contribuindo duplamente para a construção de uma sala de aula mais inclusiva, onde todos têm oportunidade de aprender juntos, com empatia e respeito às diferenças.

\subsection{Sala de Aula Invertida}

A sala de aula invertida é uma metodologia que propõe uma inversão do modelo tradicional de ensino, o qual se pauta na apresentação de conteúdos em sala de aula e realização de trabalhos individuais de fixação de conteúdos em casa.

Na sala de aula invertida, ocorre uma inversão dessas instâncias: em casa, ao invés de realizar exercícios de fixação, o aluno é convidado a estudar conteúdos previamente selecionados pelo professor (os quais devem ser diversos, tais como vídeos, textos, áudios, games etc) e, na escola, ao invés de assistir a uma aula expositiva, o espaço físico da sala de aula assume o lugar de um ambiente de esclarecimento de dúvidas e realização de atividades pautadas nos princípios da construção ativa de conhecimentos, da criatividade e do compartilhamento de saberes.

A sala de aula invertida representa uma excelente alternativa para o professor na medida em que permite a personalização do ensino, atendendo às diferentes necessidades dos alunos, o que favorece a inclusão de pessoas com necessidades educacionais especiais. Os conteúdos podem ser perfeitamente combinados com as tecnologias assistivas:

"Textos digitalizados podem ser lidos por meio de sistemas operacionais como o Dosvox ou por meio de outros recursos de tecnologias assistivas para pessoas cegas ou com baixa visão. Vídeos podem vir acompanhados de 
legendas ou de tradução de Português / LIBRAS e serem assistidos por alunos surdos, ou eles podem ainda vir com áudio descrição para serem melhor compreendidos por alunos cegos. Além disso, os materiais podem ser lidos, ouvidos ou assistidos quantas vezes o aluno precisar, de acordo com a sua necessidade." (RANGEL; GUIMARÃES, 2020).

Mas é claro que, na incorporação dessa metodologia de ensino, convém, antes de mais nada, verificar a realidade socioeconômica do aluno antes de definir a sua aplicação, uma vez que muitas famílias não possuem acesso adequado à internet em seus lares.

\subsection{Gamificação}

A gamificação é uma estratégia metodológica que vem ganhando bastante espaço no âmbito educacional. Ela consiste em um método estratégico que se baseia nos jogos para engajar pessoas, motivar a ação, promover a aprendizagem e a solução de problemas (JOSÉ, 2015). Diferente do jogo em si, porque ambientada em contexto diferente daquele dos games, a gamificação é uma metodologia ativa que utiliza de elementos da linguagem e mecânica dos jogos (tais como desafios, pontos, recompensas, significado épico, feedback instantâneo, entre outros) para promover experiências que geram respostas emocionais que, na Educação, podem ser convertidas em estímulo e motivação para o aprender.

São as características principais dessa estratégia metodológica:

- Feedback constante: O feedback constante sobre as atividades realizadas pelo aluno é importante para dar a noção de progresso sobre o que ele está fazendo e, principalmente, para dar uma orientação sobre o próximo passo. $[\ldots]$

- Desafios: Nos games, geralmente os desafios estão associados a um propósito, como derrotar um inimigo ou salvar o mundo. Na educação tradicional não acontece da mesma forma. Os alunos apenas veem os desafios, mas têm dificuldade em identificar um real motivo para superá-los. Por isso, é importante ligar as atividades acadêmicas com algo do "mundo real", que os alunos já conheçam, e assim, os desafios irão estimular os alunos a tomarem uma ação e superá-los. Estabelecer desafios traz ótimos resultados, pois os jogos podem diminuir o medo do fracasso, o que aumenta as chances de a pessoa agir e obter sucesso.

- Competição: Não é preciso estimular a competição apenas de forma direta, elegendo apenas um vencedor a cada atividade. O simples fato de parabenizar as melhores notas da turma em uma prova ou numa atividade diária, por exemplo, já promove certo nível de competição de uma maneira sadia.

- Recompensas: A recompensa é uma das características mais importantes do processo. Recompensas funcionam como uma espécie de feedback para que o usuário saiba que está fazendo a coisa certa, e também pode estimular os alunos para as próximas atividades. As recompensas podem vir em vários formatos, como pontos, medalhas, objetos colecionáveis ou reconhecimento. 
Elas podem estar pré-estabelecidas antes da realização de determinado desafio, ou podem ser concedidas com algum fator de aleatoriedade (como quando se compra um pacote de salgadinhos sem saber qual figurinha vem dentro). (BISSOLOTTI; NOGUEIRA; PEREIRA, 2014 apud JOSÉ, 2015).

Um processo educacional organizado de forma emocionante torna-se muito mais atraente para o cérebro de nossos alunos, o que potencializa o processo de aprendizagem. Aliás, um elemento central dessa estratégia metodológica é a motivação. Assim como nos jogos, dentro do sistema gamificado, as pessoas precisam se sentir motivadas a continuarem sua jornada, principalmente porque, em muitos casos, elas não estão lá porque querem - daí a importância do professor estruturar suas soluções gamificadas considerando o caráter de atividade voluntária dos jogos, levando em conta que jogamos por desejo e não por obrigação.

Para além do seu potencial de tornar o aprendizado mais lúdico e motivador, no âmbito da Educação Inclusiva, a gamificação tem grande utilidade por seu poder de promover a integração entre os participantes das propostas gamificadas, incentivando a comunicação em dinâmicas de equipe e diminuindo, assim, a sensação dos alunos portadores de necessidades educacionais especiais de estarem sozinhos ou isolados. Para tanto, é preciso que o professor cuide de estruturar sua solução gamificada com a devida atenção às barreiras e desafios enfrentados pelas pessoas com necessidades educacionais especiais (JOSÉ, 2015), conforme deve ser observado em relação a todas as metodologias ativas.

\section{PRÁTICAS PEDAGÓGICAS NA EDUCAÇÃO ESPECIAL}

Antigamente, os alunos com deficiência tinham duas alternativas de provisões escolares frente ao sistema educacional brasileiro: ou faziam parte de uma escola especial filantrópica, que não assegurava a escolarização; ou procuravam uma classe especial nas escolas públicas estaduais, que mais servia como mecanismo de exclusão do que de escolarização. Limitando, rotulando e generalizando as etapas pedagógicas do sistema de educação especial e que muitas vezes, se concentravam na "recuperação ou remediação" de supostas falhas que faltavam ao aluno para sua "normalização". De tal modo, que havia uma propensão de enfatizar supostos prérequisitos das classes especiais que relacionava e/ou remediava a incapacidade da escola em formar processos cognitivos subjacentes (MOREIRA, 2016). 
A didática assumia a infantilização do aluno com deficiência, a partir de um raciocínio equivocado que supunha que eles deveriam aprender habilidades típicas do nível pré-escolar, para adquirir "prontidão" para a alfabetização. As estratégias instrucionais se resumiam a treinar os alunos em atividades supostamente preparatórias, com ênfase na repetição, de tal forma que foi repensado um novo conceito de educação em prol da perspectiva educacional que interage com os objetivos comuns da educação. Considerando que todos terão uma educação com a mesma finalidade, aprenderão as mesmas coisas, mesmo que sejam necessárias estratégias diferentes - uma vez que cada aluno requer estratégias pedagógicas diferentes, não como medidas compensatórias e pontuais, mas sim como parte de um projeto educativo e social de caráter emancipatório e global (BRASIL, 2001, MOREIRA, 2016).

A inclusão educacional se tornou parte integrante da construção de uma sociedade mais igualitária, reconstruindo sistemas de ensino e organizando-os para dar respostas às necessidades educacionais de todos os alunos (BRASIL, 2001), envolvendo estratégias pedagógicas que correspondem a diversos procedimentos, planejamentos e métodos de intervenção dos educadores aos seus alunos na busca da construção do conhecimento. Desde que haja acessibilidade, flexibilidade, equidade e que todos trabalhem de forma colaborativa e personalizada, com respeito à diversidade (MENDES, 2010).

Indivíduos com deficiência, sejam físicas ou intelectuais, têm o direito de uma educação inclusiva, com um aprendizado digno. Havendo uma integração suficientemente adequada para proposta da universalização da educação básica, o que garante uma equidade educacional inclusiva, considerando fatores socioculturais e econômicos (KASSAR, 2009). Da mesma forma, Vygotsky (2011) considera que para professores/educadores atuarem com crianças com deficiência, deve-se buscar estratégias e pensar diretamente de cada especificidade da deficiência, e assim haverá êxito no desenvolvimento do ensino-aprendizado.

Isso implica a construção de espaços para reflexão crítica, flexibilização e criação de canais de informação nas escolas, alianças e apoios entre os profissionais e implementação de políticas públicas de valorização e formação docente. Portanto, precisamos conceber a formação continuada dos educadores como elemento crucial para a (re)construção da instituição escolar (ALMEIDA, 2004, p.244). 
Além de métodos, técnicas e práticas eficazes que estimulem o conhecimento destes alunos com necessidades especiais, neste contexto, a Educação Inclusiva apresenta suas diversidades com propostas diversificadas, que estarão baseadas nas habilidades de cada aluno (MENDES, 2010). Entretanto, para as práticas pedagógicas serem eficientes é de suma importância que o professor tenha formação específica na Educação Inclusiva, atendendo aos objetivos da Educação Especial (BRASIL, 2008). Mesmo que na maioria das vezes, os professores tenham que repensar suas estratégias de ensino, se tornando mais criativos aos métodos de inclusão e assim, proporcionando quebrar barreiras aos métodos de inclusão (SILVA; ARRUDA, 2014).

Do mesmo modo, para o professor ter mais vitória neste processo de ensinoaprendizagem é essencial conhecer o aluno, sua família, suas características e seus interesses particulares, seu meio social e seu processo de aprendizagem, trabalhando coletivamente para compreender melhor as dificuldades de aprendizagem de cada estudante, valorizando as diferenças e ritmos de aprendizagem de cada um. Caso contrário, se o planejamento não levar em conta as particularidades de cada aluno, as escolhas pedagógicas podem se converter em barreiras à inclusão educacional dos alunos com e sem deficiência (FLORIAN, 2015).

Por isso, é importante uma (re)construção coletiva do conhecimento, sendo este adequado a cada aluno, pois nem todos aprendem da mesma forma (mas todos podem aprender, se corretamente estimulados e com estratégias pedagógicas adequadas); e estendendo a inclusão fora do âmbito escolar, para que a escola possa exercer seu papel principal de educação como um todo. Somente assim o paradigma da inclusão permitirá pensar sobre a importância de uma inclusão global ao indivíduo com deficiência (SASSAKI, 2009).

\section{CONSIDERAÇÕES FINAIS}

As atividades didáticas, como planejamento de aula, devem ser realizadas antecipadamente, e executadas por um professor qualificado em sala de aula, onde se inicia essa estruturação inclusiva na qual a cooperação, colaboração e trabalho em equipe, andam juntos, fazendo com que o processo educativo seja construtivo na preparação dos alunos para a vida social de que todos têm direito. A interação, o trabalho em equipe, o enfoque no desenvolvimento de habilidades entre os alunos, a 
avaliação e discussão do funcionamento deste trabalho onde o relacionamento e a realização das tarefas são o objetivo do educador, são práticas fundamentais para que essa inclusão seja desenvolvida da melhor forma, sendo eficaz no processo evolutivo, educativo e inclusivo dentro das escolas.

A inclusão social é um novo aspecto na educação de pessoas com deficiência. Esse novo paradigma educacional trata da importância de se considerar diversas metodologias de ensino, que se aplicam a uma educação verdadeiramente inclusiva, que fortalece os necessitados para a vida social, conduzindo à igualdade social.

Vivemos numa era moderna, onde a tecnologia ocupa lugar central em nossas vidas, nos auxiliando nos estudos, na cultura, em pesquisas, entretenimento, entre outras atividades cotidianas. Por outro lado, nosso país possui muitos alunos carentes que não têm acesso à rede mundial de computadores. Diante dessa realidade, os métodos precisam ser considerados à luz dos recursos disponíveis ao professor. $\mathrm{Na}$ solução desse problema, a prática de uma escuta ativa, que envolve o aluno e também sua família, bem como a criatividade do professor, é o que fará toda a diferença no sentido de produzir resultados significativos para o conhecimento, e assimilação daquilo que foi ensinado.

A escola deve ser um espaço motivador para o ensino, contendo todos os recursos necessários para oportunizar a inclusão. Quando a escola não oportuniza tais subsídios, os professores devem unir forças no sentido de repensar sua prática, utilizando os recursos básicos disponíveis para o desenvolvimento de atividades inclusivas. O ambiente escolar deve ser repleto de energias e ambientações que direcionem o olhar do aluno para o prazer de aprender e permanecer no ambiente escolar, com alegria e acolhimento. 


\section{REFERÊNCIAS}

ALMEIDA, Mariangela Lima de. Formação continuada como processo crítico-reflexivo colaborativo: possibilidades de construção de uma prática inclusiva. Dissertação (Mestrado em Educação) - Programa de Pós-Graduação em Educação, Universidade Federal do Espírito Santo, Vitória, 2004.

ALMEIDA, Thiago. Inovação Pedagógica: uma abordagem que está mostrando como transformar a aprendizagem na educação superior. Disponível em: <https://thiagoalmeida.c o/inovação-pedagógica-uma-abordagem-que-está-mostrando-como-transformar-aaprendizagem-na-educação-2c8543b46a71 >. Thiago Almeida, 01 ago. 2017. Acesso em: 26 abr. 2021.

AMARAL, Rita de Cássia Borges de Magalhães, et al. Metodologias Ativas: Tecnologias Assistivas como um novo olhar para a Inclusão. Disponível em:

<http://www.abed.org.br/congresso 2017/trabalhos /pdf/152.pdf>. Acesso em: 13 abr. 2021.

BACICH, Lilian; MORAN, José (Org). Metodologias ativas para uma educação inovadora: uma abordagem téorico-prática. Porto Alegre: Penso, 2018.

BRASIL. Decreto 6.571 de 17 de setembro de 2008b. Institui as Diretrizes Operacionais da Educação Especial para o Atendimento Educacional Especializado - AEE. Brasília, 2008. Disponível em: <http://www.planalto.gov.br/ccivil_03/_Ato20072010/2008/Decreto/D6571.ht m>. Acesso em: 13 abr. 2021.

BRASIL. Lei no 10.172 de 2001. Aprova o Plano Nacional de Educação e dá outras providências. Disponível em: <http://www.planalto.gov.br/ccivil_03/LEIS/LEIS_2001/L10172. htm>. Acesso em: 20 abr. 2021.

BRASIL. Ministério de Educação e Cultura. Lei no 9394/96, de 20 de dezembro de 1996. Estabelece as diretrizes e bases da Educação Nacional. Brasília : MEC, 1996.

BRASIL. Subsecretaria Nacional de Promoção dos Direitos das Pessoas com Deficiência. Comitê de Ajudas Técnicas Tecnologia Assistiva (CAT). Brasília: CORDE, 2009.

FLORIAN, L. Conceptualizing Inclusive Pedagogy: The Inclusive Pedagogical Approach in Action. Inclusive Pedagogy Across the Curriculum, v.7, p.11-24. 2015.

GONZÁLEZ, J. A. T. Educação e diversidade: bases didáticas e organizativas. Porto Alegre: Artmed, 2002.

INOVAR. In: DICIO. Dicionário online de Português. Porto: 7Graus, 2021. Disponível em: <https://www.dicio.com.br/inovar/>. Acesso em: 28 abr. 2021

JOSÉ, Alexandre Botelho. Gamificação e EAD: recursos gamificados como aporte para uma educação inclusiva com foco no aluno. TCC (Especialização em Planejamento, Implementação e Gestão da EAD) - Programa de Pós-Graduação, Universidade Federal Fluminense, Niterói, 2015. Disponível em: <https://www.revistadoisat.com.br/numero6/3\%20 Alexandre_Jose_Gamificacao_Recursos.pdf>. Acesso em: 03 abr. 2021.

KASSAR, Mônica de Carvalho Magalhães; ARRUDA, Elcia Esnarriaga de; BENATTI, Mariele Moreira Santos. Políticas de Inclusão: verso e reverso de discursos e práticas. In: 
Inclusão: Práticas Pedagógicas e Trajetórias de Pesquisa. 2ª ed. Porto Alegre, p.21-31, 2009.

MENDES, E. G. Histórico do movimento pela inclusão escolar. In: MENDES, E. G. Inclusão marco zero: começando pelas creches. Araraquara: Junqueira \& Marin, p. 11-27, 2010.

MORAN, J. M. A Educação que desejamos: novos desafios e como chegar lá. 5. ed. Campinas: Papirus, 2017.

MOREIRA, Carlos José De Melo. Política Nacional de Educação Especial na Perspectiva da Educação Inclusiva: uma análise de três Programas Federais para a Educação Especial desenvolvidos pela Secretaria Municipal de Educação do município de São LuisMA, no período de 2009 a 2012. Tese (Doutorado em Educação) - Programa de PósGraduação em Educação, Universidade Estadual de Campinas, Campinas, 2016. Disponível em: <http://repositorio.unicamp.br/bitstream/REPOSIP/319216/1/Moreira_CarlosJosedeMelo _D.pdf >. Acesso em: 20 abr. 2021.

NÚCLEO PEDAGÓGICO DERAME. Metodologias Ativas para uma educação inclusiva. 2020. Disponível em: <https://youtu.be/seuiY5rbgOc>. Acesso em: 02 jul. 2021.

RADABAUGH, M. P. NIDRR's Long Range Plan - Technology for Access and Function Research Section Two: NIDDR Research Agenda Chapter 5: TECHNOLOGY FOR ACCESS AND FUNCTION. Disponível em: <http://www.ncddr.org/new/announcements/lrp/fy19992003/lrp_techaf.html>. Acesso em 13 abr. 2021.

RANGEL, Ingrid; GUIMARÃES, Délcio. Metodologias ativas na sala de aula inclusiva. Interdisciplinary Scientific Journal, n. 7, v. 1, jan./mar. 2020.

SASSAKI, Romeu K. Inclusão: acessibilidade no lazer, trabalho e educação. Revista Nacional de Reabilitação (Reação), São Paulo, Ano XII, p. 10-16, mar./abr. 2009.

SILVA, Ana Paula Mesquita da; ARRUDA, Aparecida Luvizotto Medina Martins. O Papel do Professor Diante da Inclusão Escolar. Revista Eletrônica Saberes da Educação, v. 5, n.1, 2014.

VYGOTSKY, Lev S. A defectologia e o estudo do desenvolvimento e da educação da criança anormal. Educação e Pesquisa, São Paulo, v. 37, n. 4, p. 861-870, dez. 2011. 


\section{CAPÍTULO 08}

A FORMAÇÃO DE ESPECIALISTAS EM EDUCAÇÃO ESPECIAL E INCLUSIVA

\section{Fernando Icaro Jorge Cunha}

Universidade Federal do Pampa - Unipampa

Pefil: http://lattes.cnpq.br/149558185211586

E-mail: icaro729@gmail.com

\section{Leonice Aparecida De Fátima Alves Pereira Mourad}

Universidade Federal de Santa Maria - UFSM

Perfil: http://lattes.cnpq.br/7689442989367017

E-mail: profleomourad@gmail.com

\section{Simone Baltazar Ferras}

Professora da rede Municipal de Porto Alegre

Perfil: http://lattes.cnpq.br/8571943548255077

E-mail: simoneferras@gmail.com

\section{Janete Hickmann}

Rede de Ensino Municipal de São Leopoldo - RS

Perfil: http://lattes.cnpq.br/0461298984464544

E-mail: janete22h@gmail.com

\section{Adriana Da Silva Biavaschi}

Universidade Federal do Pampa

Perfil: http://lattes.cnpq.br/6790810594771617

E-mail: fereadri2002@gmail.com

\section{Maria José Baltar De Azambuja}

Professora da Secretaria Municipal de Porto Alegre-RS

Perfil: http://lattes.cnpq.br/8379431150091984

E-mail:mj.azambuja@bol.com.br

Resumo: O presente capítulo aborda a importância da relação de uma gestão escolar influente em seu espaço para a formação integral de educadores especialistas em educação especial e inclusiva. A função ativa da gestão escolar, incorpora no grupo de professores a importância de todas as funções que desenvolvem a inclusão. Na rede pública de ensino, a gestão que atua na formulação de projetos para obter recursos financeiros e materiais inovadores, consequentemente resultará na aprendizagem dos estudantes e na qualidade do processo de inclusão. A gestão assume o papel principal de planejar as ações coletivas anualmente para a efetivação da inclusão escolar, onde, as socializações são muito importantes neste processo para investigar a necessidade do professor em sala de aula, o que pode ser feito para auxiliar o corpo docente no desenvolvimento pedagógico. Além disso, a articulação entre os professores e a comunidade é essencial como fruto da gestão participativa. Portanto, a gestão escolar deve pautar a pluralidade cultural e social, a visão de educação transgressora e democrática, desconstruindo gradativamente, através de 
processos que combatam a exclusão, o padrão de normalidade e o elitismo. $\mathrm{Na}$ prática, incluir torna-se muito difícil, pensando em um professor que necessita subsidiar as necessidades do educando com necessidades especiais, além de associar as múltiplas atividades da turma. A diferenciação das atividades ocorre para corresponder com os níveis da turma regular, considerando as particularidades do aluno incluso, o professor constitui uma múltipla atenção em sala de aula, no planejamento, e nas ações gerais do contexto escolar. Destacamos que o desenvolvimento histórico da formação de educadores especiais no país e o estabelecimento de políticas públicas para a educação especial e inclusiva, aconteceu de maneira lenta e gradual, no entanto, provocaram inúmeras mudanças no sistema de ensino brasileiro.

Palavras-chave: Formação de professores; Histórico da inclusiva; Necessidades específicas 


\section{INTRODUÇÃO}

\subsection{Aspectos Históricos da Formação dos Educadores Especiais}

Os primeiros cursos para formação de professores para atender pessoas com necessidades especiais datam dos anos cinquenta do século passado, sendo cursos de nível médio, com especial destaque aos ofertados pelo Instituto Nacional de Surdos - INES-RJ, Instituto Benjamin Constant (IBC-RJ), Instituto Pestalozzi (BH-MG) (MAZZOTA, 2005).

Em São Paulo, o primeiro curso ocorreu em 1955, no Instituto Caetano de Campos, sendo uma especialização para o ensino de cegos.

No Paraná no ano de 1961 ocorreu em Curitiba um Ciclo de Conferência que reuniu notáveis para tratar da questão da educação especial. Esse encontro resultou em um curso de especialização em deficiência mental ofertado pela PUC de São Paulo, além de dar início ao serviço especializado de educação especial naquele estado, além de cursos de especialização ministrado pela secretaria de educação. (ALMEIDA, M. 2012).

Mazzota (2005) ao referir esse momento atenta para o fato que esses cursos eram predominantemente 'normais' estando presente duas tendências: educacional e clínica ou médico pedagógica, sendo a primeira destinada a deficientes visuais e auditivos e a segunda a deficientes físicos e mentais.

No final dos anos de 1960 e anos de 1970 é que a formação desses especialistas para a ser superior em razão de Parecer 295/69 do Conselho Federal de Educação (CFE).

No ano de 1972, em São Paulo, a formação para professores de educação especial passa a ser obrigatória em nível universitário, sendo exigido o curso de Pedagogia com Habilitação em Educação Especial - que poderia ser numa área específica: deficiência auditiva (DA), deficiência mental (DM), deficiência visual (DV), deficiência física (DF) e geral (MAZZOTTA, 2005).

Em vários estados brasileiros, ainda prevalecia a formação em nível pósnormal. Só no fim dos anos de 1970 surgiram, no Paraná, os cursos de Estudos Adicionais para formação de professores para educação especial e que chegaram à década de 1980, e até os anos 2000 (MAZZOTA, 2005). 
A especialização lato sensu em deficiência mental foi ofertada pela primeira vez em Guarapuava-PR no ano de 1984 e a habilitação em educação especial no curso de pedagogia em 1996 na UNICENTRO e na UEPG. Em Irati a habilitação foi ofertada em 1996 na área de deficiência mental. A habilitação em educação especial na Universidade Estadual do Paraná teve início em 1998.

Nesse contexto a formação especializada em educação especial no Brasil nos anos 2000 estava distribuída da forma que segue:

- Cursos normais (formação de professores em nível médio);

- Cursos normais com estudos adicionais;

- Professores normalistas com cursos de 'especialização' ofertados pelos Institutos Federais ou secretarias de estado;

- Formação inicial em nível superior;

- Pedagogos com habilitação em algumas áreas da Educação Especial;

- Educadores Especiais (UFSM e UFSCar);

- Professores especializados com lato sensu ou stricto sensu;

- Professores com formação continuada;

- Professores com licenciatura em qualquer área e com aperfeiçoamento em Educação Especial;

- Professores com nível médio ou superior sem nenhuma formação em educação especial atuando com alunos com necessidades especiais; (ALMEIDA, 2012).

Após a Conferência Mundial de Educação Especial, em Salamanca, Espanha, em 1994, ocorreu uma mudança expressiva na concepção da formação de professores para atuarem na educação especial, o que foi ratificado pela nova Política Nacional de Educação Especial, visto que tal Conferência estabeleceu o compromisso dos signatários de e "implantar programas individualizados apropriados a cada criança no sistema regular de ensino" o que demanda profissionais especializados.

A LDB (9.394/96) em um esforço de valorizar a educação especial eleva a mesma a condição de modalidade de educação escolar, de sorte a concebê-la como um conjunto de recursos educacionais e estratégias de apoio à disposição dos alunos e que ofereça alternativas de atendimento, nesse sentido se fez necessário um sistema de informações e políticas adequadas às exigências e complexidades da educação especial, coordenado pelo MEC. 
O MEC lançou a série Diretrizes, para cada necessidade de educação especial, e os Parâmetros Curriculares Nacionais para a Educação Especial. Em 2004, lançou as Referências para a Construção dos Sistemas Educacionais Inclusivos, a Série Saberes e Práticas da Inclusão e, em 2005, os Ensaios Pedagógicos - Construindo Escolas Inclusivas. Ao lado da Secretaria de Educação Especial (SEESP), o MEC disponibiliza todas as publicações na internet, facilitando a pesquisa por meio do catálogo de publicações.

A Resolução CP/CNE n 02 de 11 de setembro de 2001, que Institui Diretrizes Nacionais para a Educação Especial na Educação Básica, recomendava a necessidade de trabalho pedagógico específico com as pessoas que têm necessidades especiais.

No seu artigo $3^{\circ}$ estabeleceu o que é educação especial,

Art. $3^{\circ}$ Por educação especial, modalidade da educação escolar, entende-se um processo educacional definido por uma proposta pedagógica que assegure recursos e serviços educacionais especiais, organizados institucionalmente para apoiar, complementar, suplementar e, em alguns casos, substituir os serviços educacionais comuns, de modo a garantir a educação escolar e promover o desenvolvimento das potencialidades dos educandos que apresentam necessidades educacionais especiais, em todas as etapas e modalidades da educação básica (BRASIL, 2001).

A Resolução CP/CNE n ${ }^{\circ}$ de 18 de Fevereiro de 2002 que Institui Diretrizes Curriculares Nacionais para a Formação de Professores da Educação Básica, em nível superior, curso de licenciatura, de graduação plena, estabelecendo que:

Art. $5^{\circ} \mathrm{O}$ projeto pedagógico de cada curso, considerado o artigo anterior, levará em conta que: I - a formação deverá garantir a constituição das competências objetivadas na educação básica;

II - o desenvolvimento das competências exige que a formação contemple diferentes âmbitos do conhecimento profissional do professor;

III - a seleção dos conteúdos das áreas de ensino da educação básica deve orientar-se por ir além daquilo que os professores irão ensinar nas diferentes etapas da escolaridade;

IV - os conteúdos a serem ensinados na escolaridade básica devem ser tratados de modo articulado com suas didáticas específicas;

V - a avaliação deve ter como finalidade a orientação do trabalho dos formadores, a autonomia dos futuros professores em relação ao seu processo de aprendizagem e a qualificação dos profissionais com condições de iniciar a carreira.

Parágrafo único. A aprendizagem deverá ser orientada pelo princípio metodológico geral, que pode ser traduzido pela ação-reflexão-ação e que aponta a resolução de situações-problema como uma das estratégias didáticas privilegiadas. (BRASIL, 2002). 


\title{
2. A FORMAÇÃO DE HABILIDADES E COMPETÊNCIAS DE UM EDUCADOR ESPECIAL
}

Para ser um educador antes de mais nada é preciso estar ciente de que enfrentaremos muitos desafios e dentre eles, o de desconstruirmos o que construímos em nossa trajetória discente, com base em um paradigma de exclusão, e de reconstruirmos práticas educacionais que se encaixem no perfil da inclusão.

A respeito da referida desconstrução, Naujorks (2003, p. 83) elucida que trabalhar com alunos com necessidades especiais exige do professor, entre outros;

[...] tolerância à frustração, pois deverá trabalhar também com suas perdas, ou seja, elaborar um tipo de luto. Luto do mundo acadêmico, dos saberes tradicionais e unilaterais, do professor idealizado, do aluno perfeito, de um modelo de escola e de ensino... enfim, luto de uma parte de sua história pessoal e escolar que, querendo ou não, são constitutivas de sua identidade e farão parte de sua formação.

Como Professor de Educação Especial, o educador deverá ter competências para identificar as necessidades educacionais especiais dos alunos, valorizando a educação inclusiva. (UFSM, S/D, p. 03).

\begin{abstract}
Neste sentido deverá ter também condições de flexibilizar a ação pedagógica nas áreas de conhecimento, quais sejam: déficit cognitivo, educação de surdos e dificuldade de aprendizagem, de modo adequado às necessidades especiais de aprendizagem, avaliando continuamente a eficácia do processo educativo para 0 atendimento de necessidades educacionais especiais observadas nos alunos. Ao identificar as necessidades educacionais especiais sua competência Ihe facilitará a definição e implementação de estratégias de flexibilização, adaptação curricular, procedimento didático pedagógico e práticas alternativas, adequadas ao atendimento das mesmas. (UFSM, S/D, p. 03).
\end{abstract}

O educador especial em sua formação também deverá ter competência para trabalhar em equipe, colaborando com o professor da sala de aula comum nas práticas inclusivas dos alunos com necessidades educacionais especiais.

Ter paciência com o aluno, com suas dificuldades, acreditar em suas potencialidades, dialogar com o educando, demonstrar dedicação, atenção, superar o preconceito e a discriminação social para com o aluno, ter ousadia, acreditar e fazer diferente, ser humilde e aprender com o outro, são habilidades construídas na formação educacional e pessoal de um educador especial.

Ao atuar com um aluno com deficiência física o educador especial deve ter a competência e a habilidade de conhecer as várias manifestações de sua deficiência, o desempenho físico e intelectual do aluno diante de sua deficiência, decidir as 
estratégias e os recursos a serem utilizados, conhecer e aplicar recursos de tecnologia assistiva e elaborar planos de atuação para trabalhar com o aluno. (FONSECA, 2008).

Já com alunos que têm deficiência auditiva a formação de competências e habilidades do educador especial deve ser no sentido de dominar a metodología de libras, utilizar estratégias e recursos de acordo com as possibilidades do aluno e de forma a favorecer sua autonomia, com o deficiente visual é preciso que o educador conheça os diversos recursos disponíveis para o atendimento dos mesmos, tais como o sistema Braille e os recursos de mobilidade para os alunos. (FONSECA, 2008).

Em se tratando de deficiente intelectual a formação das competências e habilidades do educador especial devem ser no sentido de o mesmo saber identificar o aluno com deficiência intelectual (DI), conhecer as síndromes que fazem parte da DI, elaborar adaptações curriculares e orientar os demais docentes, utilizar recursos e estratégias de acordo com as especificidades dos mesmos, estimular e desafiar o aluno a enfrentar conflitos e demais situações de vida diária.

O educador especial no atendimento de alunos com Superdotação/Altas Habilidades, necessita demonstrar competências e habilidades no sentido de conhecer e reconhecer as características desses educandos, flexibilidade e criatividade em sua metodologia e antes de tudo estimular o aluno a ser protagonista de suas aprendizagens.

No que se refere a alunos com Transtornos Globais do Desenvolvimento o educador precisa conhecer métodos de comunicação alternativa, planejar de acordo com a individualidade de cada um e antes de mais nada ter a habilidade de resistir à frustração, disponibilidade para o aluno e a habilidade de se envolver com o educando.

\section{A IMPORTÂNCIA DA GESTÃO ESCOLAR NA EDUCAÇÃO ESPECIAL}

A função ativa da gestão escolar, incorpora no grupo de professores a importância de todas as funções que desenvolvem a inclusão. Na rede pública de ensino, a gestão que atua na formulação de projetos para obter recursos financeiros e materiais inovadores, consequentemente o resultado será na aprendizagem dos alunos e a qualidade da inclusão.

A Inclusão escolar de pessoas com necessidades especiais assume a cada ano, importância maior, dentro da perspectiva de atender às crescentes exigências de uma sociedade em processo de renovação e de busca incessante de conhecimento. Neste contexto faz-se necessário a discussão 
do assunto na busca de melhor entende-lo. A inclusão de alunos depende de toda equipe escolar gestores, professores, equipe pedagógica e alunos, mas o gestor tem um papel muito importante, pois através de suas atitudes é que a equipe se espelhará e faz acontecer à inclusão e integração dos indivíduos com necessidades especiais. (CAVALCANTI, 2014, p. 1015).

A gestão assume o papel principal de planejar as ações coletivas anualmente para a efetivação da inclusão escolar. As socializações são muito importantes neste processo, para investigar a necessidade do professor em sala de aula, o que pode ser feito para auxiliar o corpo docente no desenvolvimento pedagógico. O incentivo para motivar a equipe e 'dar voz' aos professores é muito importante para que as carências sejam supridas corretamente.

Nesse contexto as formas de realizar a inclusão têm ocorrido das mais diversas formas e o gestor escolar apresenta grande importância, sendo necessário que o mesmo busque uma atuação baseada na diversidade em consequência da liderança que exerce, pois todos que compõem este ambiente estarão seguindo e analisando suas ações. É importante salientar que o novo causa receios, e o gestor deve estar atento, encorajando todos os envolvidos para uma busca de novas práticas (ibid, 2014, p. 1015).

A articulação entre os professores e a comunidade é essencial como fruto da gestão participativa. Projetos escolares com ênfase na inclusão, são capazes de capacitar o público escolar, para uma compreensão regional e também para uma expansão da visão realista de mundo, a valorização das diferenças ocorre através de uma dinâmica bem mais inovadora, quando todos os alunos participam dos projetos e neles são pautados a importância de valorizar o próximo e estabelecer o respeito e a ética.

\footnotetext{
Não basta seguir a legislação vigente se a própria escola e a comunidade local não estão conscientes do papel da gestão pedagógica e de suas especificidades no seu trabalho, assim como não investem na organização da escola inclusiva. É importante que todos se conscientizem que a equipe da gestão pedagógica da escola tem responsabilidades que the são próprias. À vista disso, faz-se necessária que seja devidamente especificada e fortalecida a atuação desses profissionais, haja vista que a sensibilização dos professores e demais profissionais da escola para o desenvolvimento do processo de educação inclusiva dependerá da conscientização e de ações da gestão pedagógica frente ao referido processo (VIOTO; VITALIANO, 2019, p. 57).
}

Portanto, a gestão escolar deve pautar a pluralidade cultural e social, a visão de educação transgressora e democrática. Desconstruindo gradativamente, através de processos que combatem a exclusão, o padrão de normalidade e o elitismo. Além disso, a gestão deve preocupar-se com a necessidade de buscar alternativas de formação continuada, para capacitar, atualizar e preparar os profissionais da 
educação, para o exercício de um magistério inclusivo de qualidade (MARTINS; ANDRADE, 2016).

\section{OS DESAFIOS DE INCLUIR EM FUNÇÃO DA MÚLTIPLA ATENÇÃO EM} SALA DE AULA

$\mathrm{Na}$ prática, incluir torna-se muito difícil, pensando em um professor que necessita subsidiar as necessidades do educando com necessidades especiais, além de associar as múltiplas atividades da turma. A diferenciação das atividades ocorre para corresponder com os níveis da turma regular, considerando as particularidades do aluno incluso, o professor constitui uma múltipla atenção em sala de aula, no planejamento, e nas ações gerais do contexto escolar.

[...] As concepções que emergem nas falas dos professores aparecem em três noções inter-relacionadas: as concepções de normalidade, de deficiência e de inclusão. A concepção de normalidade pode ser organizada em dois grupos. O primeiro recusa o conceito, questionando a ideia de normalidade; desse ponto de vista, não existem normais, ou cada um só é normal até certo ponto. O segundo assume a existência de uma normalidade. Para alguns professores, normalidade tem relação com a aceitação pelo outro, fazer coisas comuns, participar, interagir, brincar (ANJOS; ANDRADE; PEREIRA, 2009, p. 119).

Conforme a citação supracitada, as autoras discorrem sobre a concepção de normalidade empregada na visão do ensino regular. A motivação do professor e o empenho é essencial neste processo, para garantir a ambientalização do aluno incluso, evitando que o mesmo sinta-se mal, por conta de sua deficiência.

[...] Os principais embates evidenciados no discurso são: o enfrentamento entre inclusão entendida como processo ou como produto, embate que, no limite, definirá a maior ou menor participação e intervenção dos professores nos processos inclusivos; os sentimentos caracterizados como de crise, os quais podem levar a elaborações que modifiquem o fazer pedagógico e 0 projetem para além do espaço escolar (Ibid, 2009, p. 127).

Além disso, as autoras discorrem sobre a necessidade de modificar o "fazer pedagógico" como estratégia de universalizar a prática inclusiva, não sendo restrita somente ao ambiente escolar. É difícil concentrar-se fixamente em uma dualidade de constante controvérsia, entretanto, é possível apreciar a inclusão, com a participação dos alunos em geral neste processo contínuo, assim, o professor terá um maior aproveitamento e o rendimento será gradativo e processual, além de garantir que a atenção concentrada, seja apenas mero detalhe consecutivo, de uma prática inclusiva participativa e harmoniosa. 


\section{CONSIDERAÇÕES FINAIS}

Procuramos, neste artigo, salientar a trajetória histórica da formação de especialistas em educação especial e inclusiva no Brasil, assim como as diretrizes fundamentais para a prática qualificada destes profissionais. Destacou-se que o desenvolvimento histórico da formação de educadores especiais no país e o estabelecimento de políticas públicas para a educação especial e inclusiva, aconteceu de maneira lenta e gradual, no entanto, provocaram inúmeras mudanças no sistema de ensino brasileiro.

Verificou-se que a formação docente para a modalidade especial e inclusiva requer conhecimentos, competências e habilidades que favoreçam o sucesso educacional em meio às diversidades. Portanto, o desenvolvimento profissional do educador especial vai se concretizar na atuação cotidiana em sala de aula, em um constante aperfeiçoamento pautado na paciência, na flexibilidade, no fazer coletivo, na capacidade empática e na sensibilidade.

Trabalhar com alunos com deficiência é uma tarefa desafiadora, que exige grande comprometimento com o processo de aprendizagem discente. $O$ especialista em educação especial e inclusiva deve otimizar atividades multidisciplinares diferenciadas e metodologias eficientes para a prática pedagógica, sempre atentandose às individualidades, para que os alunos sejam estimulados a evidenciar suas potencialidades.

Considerando a perspectiva da gestão escolar na educação especial, verificouse a importância deste segmento em proporcionar um ambiente harmonioso e uma educação plena para todos. Faz-se necessário que os gestores escolares promovam uma administração democrática, que possibilite a dialogicidade com os professores e com a comunidade escolar como um todo, implicando na construção coletiva de uma ação pedagógica apropriada ao aluno com deficiência. É importante ressaltar que o trabalho do gestor escolar no contexto inclusivo, deve ser flexível, considerando as diversidades e as necessidades singulares de cada estudante.

Além disso, ressaltou-se que são muitos os desafios para se fazer uma inclusão de qualidade dos alunos que apresentam múltipla atenção em sala de aula. É necessário que o profissional especializado estabeleça uma constante busca por estratégias e práticas pedagógicas variadas, que possam favorecer uma melhor 
atuação do discente na realização das tarefas. Para tanto, é imprescindível o envolvimento da família no processo de ensino-aprendizagem, fortalecendo o desenvolvimento cognitivo, relacional e humano dos alunos.

Assim, neste artigo, buscou-se refletir acerca da importância da formação plural e sensível de especialistas em educação especial e inclusiva. Admite-se que essa formação deve ser construída coletivamente, com a partilha de experiências e conhecimentos, capazes de proporcionar uma educação mais significativa para os alunos com deficiência. 


\section{REFERÊNCIAS}

ALMEIDA, M. (2012). Formação do professor para a educação especial: história, legislação e competências. Revista Educação Especial, 0, 23-32. Recuperado de

https://periodicos.ufsm.br/educacaoespecial/article/view/4912.

BRASIL, LDB ( Lei № 9.394/96).

BRASIL, Resolução CP/CNE nº2 de 11 de setembro de 2001.

BRASIL, Resolução CP/CNE n¹ de 18 de Fevereiro de 2002.

CAVALCANTI, Ademilson Vedovato. O Papel do Gestor Escolar no Processo de Inclusão. Encontro de Ensino, Pesquisa e Extensão, Presidente Prudente, 2014. Disponível: em: http://www.unoeste.br/site/enepe/2014/suplementos/area/Humanarum/Educa\%C3\%A7\%C3 \%A3o/O\%20PAPEL\%20DO\%20GESTOR\%20ESCOLAR\%20NO\%20PROCESSO\%20DE\% 20INCLUS\%C3\%83O.pdf Acesso em: 24/05/2021.

FONSECA, Vitor. desenvolvimento psicomotor e aprendizagem. Porto Alegre: ARTMED, 2008.

MARTINS, Clarissa de Andrade Fernandes; ANDRADE, Lucimary Bernabé Pedrosa de. A Importância da Formação Continuada do Professor para a Inclusão da Criança com Deficiência na Educação Infantil. II Seminário Internacional de Pesquisa em Políticas Públicas e Desenvolvimento Social, 2016. Disponível em:https://www.franca.unesp.br/Home/ Posgraduacao/planejamentoeanalisedepoliticaspublicas/iisippedes2016/artigo-sippedesclarissa..pdf Acesso em: 24/05/2021.

MAZZOTTA, Marcos J. S..Educação especial no Brasil: história e políticas públicas. 5. ed.. São Paulo: Cortez, 2005.

NAUJORKS, Maria Inês. Inclusão de Alunos com Necessidades Educativas especiais. Disponível em: https://periodicos.ufsm.br/educacaoespecial/issue/view/253 2003. Acesso em: 18 abr 2021.

UNIVERSIDADE FEDERAL DE SANTA MARIA. (UFSM). Perfis do Educador Especial Habilidades e Competências. S/D. Disponível em:

https://www.ufsm.br/cursos/graduacao/santa-maria/educacao-especial/perfil-profissiona/ Acesso em: 18 abr 2021.

VIOTO, Josiane Rodrigues Barbosa; VITALIANO, Celia Regina. O papel da gestão pedagógica frente ao processo de inclusão dos alunos com necessidades educacionais especiais. Dialogia, São Paulo, n. 33, p. 47-89, 2019. https://doi.org/10.5585/Dialogia.n33.13 


\section{CAPÍTULO 09}

SALA DE RECURSOS MULTIFUNCIONAIS NO DESENVOLVIMENTO DIDÁTICO-PEDAGÓGICO

Fernando Icaro Jorge Cunha

Universidade Federal do Pampa - Unipampa

Perfil: http://lattes.cnpq.br/149558185211586

E-mail: icaro729@gmail.com

\section{Adriana Da Silva Biavaschi}

Universidade Federal do Pampa

Perfil: http://lattes.cnpq.br/6790810594771617

E-mail: fereadri2002@gmail.com

\section{Caroline Pugliero Coelho}

Universidade Federal do Pampa/UNIPAMPA

Perfil: http://lattes.cnpq.br/1138015620367845

E-mail: carolinecoelho.aluno@unipampa.edu.br

\section{Luciana Martins Vieira}

Professora da Rede Municipal de Ensino de Porto Alegre

Perfil: http://lattes.cnpq.br/4916051022113025

E-mail: lumartinsv@gmail.com

\section{Maria José Baltar De Azambuja}

Professora da Secretaria Municipal de Porto Alegre-RS

Perfil: http://lattes.cnpq.br/8379431150091984

E-mail:mj.azambuja@bol.com.br

\section{Janete Hickmann}

Rede de Ensino Municipal de São Leopoldo - RS

Perfil: http://lattes.cnpq.br/0461298984464544

E-mail: janete22h@gmail.com

\section{Janete Mendonça Chrispim Maia}

Universidade Iguaçu - UNIG

Perfil: http://lattes.cnpq.br/7657514122345716

E-mail: Jmendonca.prof@gmail.com

Resumo: O presente capítulo tem como finalidade promover reflexões sobre a importância das salas de recursos multifuncionais como contribuição para o processo formativo de estudantes com necessidades específicas, assim como para o desenvolvimento didático-pedagógico de docentes do AEE. Sabemos que para que haja a inclusão não basta apenas uma escola com educação especial, também há a necessidade de uma sala com recursos que possam apoiar a inclusão., e esse fator importante diz respeito ao currículo escolar inclusivo. Neste currículo precisa haver flexibilização para que possa atender a todos, ou seja, cada aluno diagnosticado 
apresenta um tipo de necessidade; sendo assim, um currículo flexibilizado poderá atender a cada um individualmente, seja qual for a dificuldade, seja ela intelectual, visual ou físico, dessa forma, favorecendo o desenvolvimento do estudante. Dentro do contexto de educação especial e inclusiva, a flexibilização curricular se faz necessária a fim de que os alunos com deficiência, ao serem incluídos dentro das salas de aula de ensino regular, encontrem condições propícias para o desenvolvimento de suas aprendizagens. O conceito de flexibilização curricular reflete uma percepção de apresentar currículo flexível dentro de uma proposta de trabalho pedagógico inclusivo. A inclusão só poderá ser realmente efetivada no momento em que houverem ações conjuntas e práticas colaborativas entre os diferentes profissionais envolvidos com o aluno, entendendo que, são necessários para uma educação inclusiva de qualidade o engajamento da escola em sua totalidade para com este objetivo, assim como políticas públicas que favoreçam a ampliação de recursos para que as escolas obter e construir suas salas de recursos multifuncionais, consideradas essenciais para esta finalidade.

Palavras-chave: Inclusão; Educação inclusiva; AEE. 


\title{
1. INTRODUÇÃO
}

A implementação das salas de recursos multifuncionais na rede pública de ensino possibilita o desenvolvimento de práticas inclusivas e propõe condições de acesso adequadas, resultando no enriquecimento da aprendizagem de estudantes da educação especial e inclusiva no ensino regular. De acordo com o Decreto $n^{\circ}$ 7611/2011, as salas de recursos multifuncionais são ambientes dotados de equipamentos, mobiliários e materiais didáticos e pedagógicos para a oferta do atendimento educacional especializado (AEE).

Segundo Alves (2006, p. 14), a denominação sala de recursos multifuncionais refere-se:

\begin{abstract}
[...] ao entendimento de que esse espaço pode ser utilizado para o atendimento das diversas necessidades educacionais especiais e para desenvolvimento das diferentes complementações ou suplementações curriculares. Uma mesma sala de recursos, organizada com diferentes equipamentos e materiais, pode atender, conforme cronograma e horários, alunos com deficiência, altas habilidades/superdotação, dislexia, hiperatividade, déficit de atenção ou outras necessidades educacionais especiais. Para atender alunos cegos, por exemplo, deve dispor de professores com formação e recursos necessários para seu atendimento educacional especializado. Para atender alunos surdos, deve se estruturar com profissionais e materiais bilíngües. Portanto, essa sala de recursos é multifuncional em virtude de a sua constituição ser flexível para promover os diversos tipos de acessibilidade ao currículo, de acordo com as necessidades de cada contexto educacional.
\end{abstract}

A partir de 2007, o Programa de Implantação de Salas de Recursos Multifuncionais foi instituído para aprimorar o atendimento educacional especializado na educação especial e inclusiva, oferecida pela rede pública de ensino do país. O programa foi definido com o intuito de firmar apoio técnico e financeiro aos sistemas de ensino, garantindo o acesso ao ensino regular e a oferta do AEE aos alunos do público-alvo da Educação Especial (BRASIL, 2007).

Assim sendo, as salas de recursos multifuncionais são fundamentais para eliminar os obstáculos que dificultam o aprendizado dos alunos com deficiência. Pata tanto, existem dois tipos de salas de recursos multifuncionais, as salas tipo I e tipo II.

Tanto as salas do tipo I quanto do tipo II, são compostas por equipamentos específicos para o atendimento educacional especializado, mobiliários, materiais didáticos e recursos pedagógicos e de acessibilidade. No entanto, as salas do tipo II são planejadas para o atendimento de alunos cegos, trazendo recursos como impressora Braille, máquina de datilografia Braille, reglete de mesa, punção, soroban, 
guia de assinatura, globo terrestre acessível, kit de desenho geométrico acessível, calculadora sonora e software para produção de desenhos gráficos e táteis.

Nesse contexto, estabeleceu-se o decreto $n^{0}$ 6.571/2008 e posteriormente, 0 decreto $\mathrm{n}^{0}$ 7.611/2011, que dispõe sobre a educação especial e o atendimento educacional especializado, elencando os seguintes objetivos no Art. 3ํ:

\footnotetext{
I - prover condições de acesso, participação e aprendizagem no ensino regular e garantir serviços de apoio especializados de acordo com as necessidades individuais dos estudantes;

II - garantir a transversalidade das ações da educação especial no ensino regular;

III - fomentar o desenvolvimento de recursos didáticos e pedagógicos que eliminem as barreiras no processo de ensino e aprendizagem; e

IV - assegurar condições para a continuidade de estudos nos demais níveis, etapas e modalidades de ensino (BRASIL, 2011).
}

Os docentes que atuam no AEE devem ter capacitação para o trabalho a ser desenvolvido nas salas de recursos multifuncionais, aplicando seus conhecimentos em diferentes áreas, nas tarefas com os recursos específicos oferecidos. Dessa maneira, o objetivo desses profissionais é melhorar a adaptação e aprendizagem dos alunos do atendimento educacional especializado nas atividades de complementação e suplementação curricular (PASIAN; MENDES; CIA, 2014).

Todavia, sabe-se que existe certa fragilidade na formação dos professores de turmas regulares no que se refere aos conteúdos básicos para trabalhar com alunos com deficiência. Logo, é essencial que exista conexão entre os docentes da sala de aula comum e do AEE, pois "irá refletir na construção de um bom ambiente de ensinoaprendizagem, fundamental para a promoção da inclusão e para o sucesso escolar de todos os alunos, principalmente daqueles com Necessidades Educativas Especiais" (MIRANDA, 2015, p. 84).

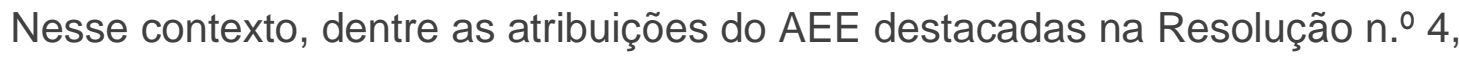
de 2 de outubro de 2009, que institui as Diretrizes Operacionais para o Atendimento Educacional Especializado na Educação Básica, o Art. 9ำ ressalta a importância da cooperação entre os demais segmentos escolares:

Art. 9ำ A elaboração e a execução do plano de AEE são de competência dos professores que atuam na sala de recursos multifuncionais ou centros de AEE, em articulação com os demais professores do ensino regular, com a participação das famílias e em interface com os demais serviços setoriais da saúde, da assistência social, entre outros necessários ao atendimento (BRASIL, 2009).

Sendo assim, na perspectiva do trabalho integrado a fim de atender estudantes com deficiência, 
[...] as salas de recursos multifuncionais dentro das escolas, devem oferecer condições que levem 0 sujeito, a superar suas necessidades particulares/especificas e desenvolver suas habilidades, promovendo o sujeito as mais variadas situações pedagógicas, com os diversos materiais que a sala de recurso multifuncional possa oferecer, permitindo experimentações, elevando seu potencial cognitivo, sendo assim inserindo culturalmente e socialmente, bem como, estimular seu desenvolvimento intelectual, físico e psicológico dentro do espaço escolar, com os diversos profissionais que lá existem (FARIAS; SANTOS, 2020, p. 05).

Segundo Rodrigues e Batista (2015), a utilização das ferramentas didáticas e pedagógicas presentes na sala de recursos multifuncionais, antes de tudo, precisa se expandir para beneficiar a todos os que dela precisam, e nunca deve substituir o atendimento do estudante na classe regular, pois essa medida contribuirá para tornar uma educação excludente e seletiva em uma educação cada vez mais inclusiva.

Desse modo, neste artigo teceremos algumas considerações sobre a importância das salas de recursos multifuncionais, assim como da articulação entre os profissionais especializados, professores regulares e demais segmentos da comunidade escolar, para o crescimento didático-pedagógico.

\section{O PAPEL DO PROFESSOR NA ARTICULAÇÃO DO ATENDIMENTO EDUCACIONAL ESPECIALIZADO}

A sala de recursos multifuncionais (SRM) é um espaço escolar com diversos materiais didático-pedagógicos, contendo equipamentos direcionados para alunos com necessidades especiais. Para atuar nesta sala o profissional precisa ter domínio das metodologias que agregam no desenvolvimento dos educandos em escolas de ensino regular. A sala de recursos multifuncionais constitui a prioridade da inclusão, pois estabelece o direcionamento inclusivo, bem como, a inserção e o desenvolvimento do educando no ensino regular.

Salas de Recursos: serviço de natureza pedagógica, conduzido por professor
especializado, que suplementa (no caso dos superdotados) e complementa
(para os demais alunos) o atendimento educacional realizado em classes
comuns [...]. Esse serviço realiza-se em escolas, em local dotado de
equipamentos e recursos pedagógicos adequados às necessidades
educacionais especiais dos alunos, podendo estender-se a alunos de escolas
próximas, nas quais ainda não exista esse atendimento. Pode ser realizado
individualmente ou em pequenos grupos, para alunos que apresentem
necessidades educacionais especiais semelhantes, em horário diferente
daquele em que frequentam a classe comum. [...]. (BRASIL, 2001, p.50).
É essencial que os setores de Educação Especial procurem absorver
educadores que saibam utilizar os diversos métodos da Educação Especial e 
traçar projetos pedagógicos de intervenção, individualizados, com metas explicitadas e sistemas de avaliação adequados. (CRESCÊNCIO; BRUNONI, 2018, p. 196).

A atuação dos professores compõe o papel fundamental de articular o ensino regular, a inclusão e o atendimento educacional como mediador deste processo. profissional da SRM deve sempre acompanhar novas tecnologias e recursos, além de promover o incentivo de atividades que despertam a imaginação, criatividade, linguagem, raciocínio, percepção, memória, entre outras atividades que promovem a socialização e interação, promovendo a valorização das diferenças, a fim de evitar a discriminação (BAUCH; LÖHR, 2014).

\section{FLEXIBILIZAÇÃO CURRICULAR NA EDUCAÇÃO ESPECIAL}

Dentro do contexto de educação especial e inclusiva, a flexibilização curricular se faz necessária a fim de que os alunos com deficiência, ao serem incluídos dentro das salas de aula de ensino regular, encontrem condições propícias para o desenvolvimento de suas aprendizagens. Assim, contribuindo para o seu processo de ensino e suas evoluções, respeitando as necessidades educacionais especiais de cada um.

Santos e Braun (2017, p.18) explicam que:

As flexibilizações podem ser definidas como o conjunto de medidas e modificações que buscam a aprendizagem e o desenvolvimento dos alunos que se deparam com alguns impasses no que diz respeito a forma de estruturar o ensino.

O conceito de flexibilização curricular reflete uma percepção de apresentar currículo flexível dentro de uma proposta de trabalho pedagógico inclusivo. Segundo Garcia (2005, p.15) a flexibilidade curricular relaciona um "significado prático e instrumental dos conteúdos básicos, favorecendo uma interpretação de hierarquização do acesso aos conhecimentos a partir das diferenças individuais". Sendo assim, quando se flexibiliza um currículo, se pensa nas necessidades educacionais singulares dos alunos, adequando a apresentação dos conteúdos de forma a potencializar o processo de aprendizagem, respeitando suas limitações e seu ritmo. 
Figura 1: Fluxograma Flexibilização Curricular

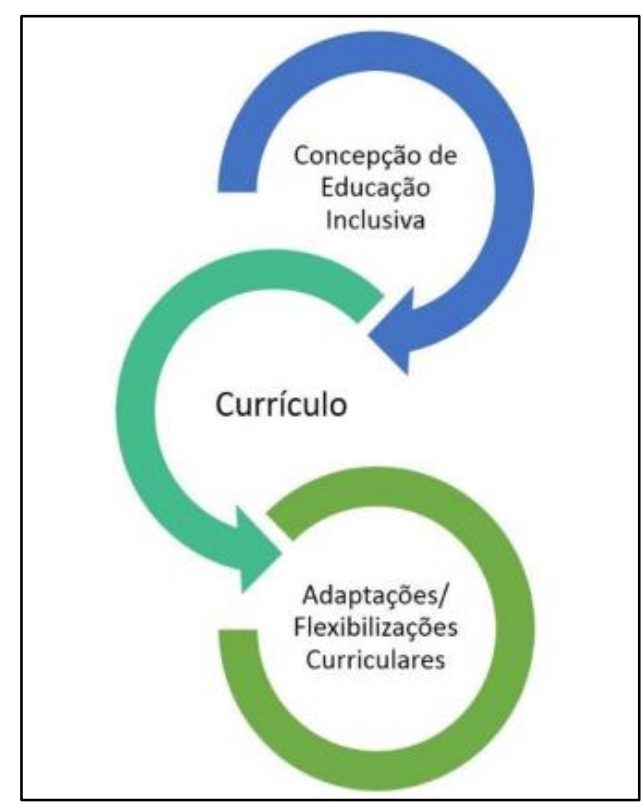

Fonte: Santos e Braun (2017, p.18)

Rapoli et al. (2010) afirma que "a escola comum se torna inclusiva quando reconhece diferenças dos alunos diante do processo educativo e busca a participação e o progresso de todos, adotando novas práticas pedagógicas". Essas práticas pedagógicas devem ser planejadas de acordo com as necessidades educacionais dos alunos, em suma, isso é a flexibilização curricular, um planejamento diferenciado, dentro do currículo, que atenda as especificidades de ensino dos alunos com deficiência.

O processo de flexibilização [...] não pode ser entendido como uma mera modificação ou acréscimo de atividades complementares na estrutura curricular. Ele exige que as mudanças na estrutura do currículo e na prática pedagógica estejam em consonância com os princípios e com as diretrizes do Projeto Político Pedagógico, na perspectiva de um ensino de qualidade para todos os alunos (LOPES, 2008, p. 12)

Dentro de uma perspectiva mais prática, de se pensar como flexibilizar currículo, propostas ou atividades para os alunos com deficiência, primeiro precisamos pensar em quais necessidades esse aluno precisa desenvolver, ou ainda, quais limitações ele apresenta. Assim, o diagnóstico do aluno é o primeiro passo para o planejamento do trabalho pedagógico, a partir deste diagnóstico será possível identificar as necessidades dos alunos e planejar as flexibilizações a serem desenvolvidas. Daí vem a necessidade de um trabalho e ensino colaborativo entre professores regentes e professores do AEE. Segundo Santos e Braum (2017, p. 20) 
a proposta de ensino colaborativo apresenta como base a "cooperação entre o professor do núcleo comum e professor de AEE no campo mais próximo do aluno, na sala de aula. Nesta proposta estes professores dividem a responsabilidade de planejar, instruir e avaliar ações pedagógicas”.

Coelho (2020) apresenta algumas possibilidades de flexibilização para alunos com deficiência visual, sinalizando a utilização de materiais de percepção tátil como mapas táteis nas atividades de geografia, esquemas em alto relevo para atividades de ciências e até bolas com guizo para as aulas de educação física. A mesma autora salienta que todas essas flexibilizações podem ser efetivadas utilizando "materiais de fácil acesso, muito presentes no âmbito pedagógico escolar" (COELHO, 2020, p. 83). Santos e Braun (2017) apresentam sugestões de flexibilizações para alunos com deficiência intelectual, sugerindo o uso de materiais concretos e visuais para que os alunos possam observar e manusear objetos e materiais. As autoras ainda sugerem nas avaliações "substituir a expressão escrita pela oral, garantindo uma avaliação mais adequada da aprendizagem a partir de outra via de comunicação". Também, na área lógico-matemática "apoiar a memória e favorecer a relação entre o numeral (desenho) e a quantidade (número)" (SANTOS; BRAUN, 2017, p. 23).

\section{TRABALHO EM REDE - ARTICULAÇÃO COM OUTROS PROFISSIONAIS}

Recentemente a Organização das Nações Unidas para a Educação, Ciência e Cultura (UNESCO, 2008) publicou um documento em que se apresenta um conceito amplo de educação inclusiva, concebendo-a "como um princípio e uma orientação geral para fortalecer a educação, com vistas a um desenvolvimento sustentável, aprendizagem ao longo da vida para todos e acesso igual de todos os níveis da sociedade às oportunidades de aprendizagem" (p. 15).

Para que a inclusão possa realmente acontecer, não basta apenas garantir a matrícula do aluno a escola é preciso em primeiro lugar ressignificar práticas e realizar uma mudança em todo sistema, políticos, gestores, funcionários, profissionais, comunidade, pais, estudantes e, fundamentalmente, o professor, todos devem formar uma rede de apoio ao aluno. 
A inclusão só poderá ser realmente efetivada no momento em que houver ações conjuntas e práticas colaborativas entre os diferentes profissionais envolvidos com o aluno.

Arguelles, Hughes e Schumm (2000) apontam que a colaboração entre a educação regular e a educação especial tem consumido tempo e esforços consideráveis aos gestores para (re)estruturação da educação regular e especial, de forma a atender efetivamente às necessidades dos alunos nos ambientes integrados.

\begin{abstract}
No Brasil, almejando-se essa integração e o trabalho de parceria entre os profissionais da educação regular e da educação especial foi criado o Atendimento Educacional Especializado (AEE) garantindo a todos os EPAEE o atendimento complementar (para os estudantes com deficiência ou transtornos globais do desenvolvimento) ou suplementar (estudantes com altas habilidades/superdotação) para frequentarem a escola regular. É importante esclarecer que o AEE não pode ser confundido com reforço escolar, mas seu serviço de natureza pedagógica deve constituir-se como um conjunto de procedimentos específicos de forma a mediar e auxiliar o processo de apropriação, construção e produção de conhecimentos. (BRASIL, 2008; 2010).
\end{abstract}

Cabe ao professor do AEE trabalhar com o professor da sala de aula comum de forma colaborativa, planejando e replanejando as ações educativas para o educando de acordo com suas necessidades específicas, buscando o desenvolvimento do aluno e proporcionando apoio psicológico para os mesmos.

Outro fator relevante a beneficiar a Educação Inclusiva, segundo Bendinelli, Andrade e Prieto (2012) é a criação de redes de apoio tendo por base a existência de orientações normativas nacionais e internacionais enfatizando a importância das ações intersetoriais e do trabalho colaborativo para o sucesso do ensino inclusivo.

O trabalho em rede deve ter um caráter colaborativo, onde cada profissional irá atuar para um bem comum. "A rede de apoio baseia-se na premissa de que cada um tem suas capacidades, potencialidades, dons e talentos, inclusive os alunos classificados como pessoas com deficiência, que podem ser usados para proporcionar apoio e ajuda a seus companheiros da comunidade." (STAINBACK; STAINBACK, 1999, p. 226).

Fazem parte da rede de apoio; o diretor da escola, o coordenador pedagógico, o supervisor de ensino, o professor da sala de aula regular, o professor do AEE, os funcionários, os pais, os alunos, a comunidade, o psicólogo, o fonoaudiólogo, o terapeuta ocupacional, o assistente social entre outros. 
O envolvimento de toda a rede de profissionais envolvidos com o aluno e as parcerias com os professores, permite uma melhor compreensão das especificidades dos educandos, podendo assim contribuir de forma mais efetiva na aprendizagem dos alunos com deficiências

A família como parte integrante dessa rede de apoio desempenha um papel primordial na escolarização dos alunos, pois, é a fonte de informação e o elo de ligação entre os alunos, escola e demais profissionais que irão participar do dia a dia e da vida escolar do educando.

Por isso, família e escola devem ser as primeiras instituições a se mobilizarem juntas para tecer redes de inclusão para extrapolar a educação inclusiva no contexto escolar e acadêmico, ou seja, para tecer uma educação inclusiva para a sociedade em todos os seus contextos e territórios. (ORRÚ, 2017).

\section{FORMAÇÃO EM SERVIÇO - INSTRUMENTALIZAÇÃO DOS PROFESSORES DA ESCOLA}

Desde as primeiras publicações das legislações sobre a inclusão de alunos com deficiências nas escolas de ensino comum das redes de ensino de todo o país, tivemos poucos avanços para dar suporte aos professores que estão em sala de aula recebendo estes alunos. Uma das legislações mais atuais, a Lei Brasileira de Inclusão (BRASIL, 2015), em seu capítulo IV, reforça a formação docente em seu artigo 28, e também aspectos como projeto pedagógico, serviços e adaptações necessárias que objetivam maximizar o desenvolvimento acadêmico.

Com o advento da Educação Inclusiva, o direito universal irrestrito à educação passa a ser reafirmado, porém não basta apenas a inserção física na sala de aula para que efetivamente todos os alunos aprendam. É necessário atendimento às necessidades específicas de alguns alunos, ou seja, a garantia de que todos aprendam, traduz-se em um desafio para a prática pedagógica dos professores, até então formados para atuar em turmas de caráter homogêneo. Surge a necessidade de encontrar maneiras diferenciadas para que qualquer barreira que um aluno apresente para aprender os conteúdos acadêmicos seja eliminada. (Redig, Mascaro e Dutra, 2017).

Para adaptar é preciso remover barreiras, inicialmente as arquitetônicas, mas também barreiras pedagógicas e atitudinais. Para remover as barreiras do ensino é preciso dar suporte aos professores através de programas de formação continuada e incentivo às especializações. Pois, se familiarizando com esse universo que é a inclusão, o medo e as barreiras se dissolvem. 
Sobre essa formação, acreditamos que a mesma deve acontecer com a troca entre os pares, através de uma reflexão crítica sobre as práticas de sala de aula, partindo do desenvolvimento de sua prática, os professores aprimoram o que realmente funciona e reformulam atividades, buscando maior eficiência e aproveitamento da aula. (REDIG; MASCARO; DUTRA, 2017).

O professor precisa permitir-se não saber tudo e colocar-se na condição de aprendiz. Dessa forma, aprender se torna mais fácil e a qualificação do trabalho docente cresce.

A formação de professores é o caminho para que haja coesão entre teoria e prática, é onde a construção de conhecimento, o estudo se funde com a troca de experiências e a análise das próprias vivências.

Sendo assim, a formação de professores deve ser continuada e em serviço,
de forma constante, pois há necessidade de estudos para o conhecimento
das particularidades das deficiências e as diversas estratégias para o
processo de ensino-aprendizagem desses educandos. (REDIG; MASCARO;
DUTRA, 2017).

A formação de professores nesse sentido visa promover não só a instrumentalização pedagógica com recursos e técnicas, ou o esclarecimento sobre as síndromes e deficiências, mas também a ruptura de paradigmas.

A mudança de atitude frente a escola das diferenças, traz em si a necessidade de repensar o trabalho pedagógico desenvolvido. Esta é uma barreira complexa e difícil de se remover pois exige do professor a mudança que vem de dentro para fora. E para isso acontecer é preciso de tempo.

\section{CONSIDERAÇÕES FINAIS}

Neste artigo procurou-se destacar a necessidade de se ter na escola uma sala de recursos multifuncionais no desenvolvimento didático-pedagógico. Sabemos que para que haja a inclusão não basta apenas uma escola com educação especial, também há a necessidade de uma sala com recursos que possam apoiar a inclusão. Materiais acessíveis aos com necessidades especiais é de suma importância para o bom atendimento no processo de ensino, uma vez que esses materiais possibilitam maior aprendizagem.

Observamos, também, que para o bom desenvolvimento desses recursos, precisa haver uma boa comunicação entre o professor do AEE juntamente com o professor da sala de aula comum; a articulação entre eles fará com que as 
necessidades dos alunos sejam atendidas, uma vez que será o professor que fica com o aluno, no dia a dia, que irá relatar ao professor do AEE as dificuldades enfrentadas pelos alunos. Daí o professor especializado irá criar atividades que possam atender a esses alunos. A sala de recursos será uma outra alternativa no atendimento especial, assim será possível um atendimento direcionado ao enfrentamento das dificuldades.

Outro fator importante diz respeito ao currículo escolar inclusivo. Neste currículo precisa haver flexibilização para que possa atender a todos, ou seja, cada aluno diagnosticado apresenta um tipo de necessidade; sendo assim, um currículo flexibilizado poderá atender a cada um individualmente, seja qual for a dificuldade, seja ela intelectual, visual ou física. Dessa forma, irá contribuir no processo de desenvolvimento do aluno. Será nesse momento que deverá haver a troca entre os professores do AEE e o da sala de aula comum.

Observou-se que além dos papéis dos professores de sala de aula comum e da sala de recursos, também precisa de um engajamento entre todo o pessoal que trabalha na escola. Porque os alunos não ficarão o tempo todo em sala de aula, precisando assim que haja uma colaboração de toda equipe pedagógica, profissionais especializados, funcionários e educadores. Incluir significa não deixar de fora, inserirse, então o aluno precisa estar inserido na escola e para tanto precisa da colaboração de todos, tanto na escola como fora dela, em casa, com a família.

Apresentou-se a proposta de que os professores precisam de formação continuada para promover a instrumentação pedagógica. Se o professor da sala de aula comum não souber lidar com as diferenças ficará impossível a inclusão. Dessa forma, todos os professores precisam entender um pouco sobre as deficiências e isso só será possível se houver continuidade nos estudos. Percebemos que para haver inclusão precisa de cooperação entre todas as pessoas que trabalham na escola, incluindo é claro os professores das aulas comuns.

Por fim, entendemos que é necessário não só uma educação especial inclusiva de qualidade como também uma sala de recursos que possa atender todas as dificuldades dos alunos. Também que toda a escola esteja engajada no aspecto inclusão. Os alunos com dificuldades precisam ser respeitados e para isso é necessário que os professores entendam suas necessidades e para tanto que os professores se coloquem sempre com aprendizes. 


\section{REFERÊNCIAS}

\section{ALVES, D. O. Sala de recursos multifuncionais: espaços para atendimento educacional especializado. Brasília: MEC/SEESP, 2006.}

ARGUELLES, M. E.; HUNGES, M. T.; SCHUMM, J. S. Co-Teaching: a different approach to inclusion. Principal (Reston, Va.), 79, ํ․ 4, p. 50-51, 2000.

BAUCH, Kátia Belasque; LÖHR, Suzane. Secretaria de Estado da Educação.

Superintendência de Educação. Os Desafios da Escola Pública Paranaense na Perspectiva do Professor PDE, 2014. Curitiba-PR: SEED/PR., 2016. V.1. (Cadernos

PDE). Disponível em: http://www.diaadiaeducacao.pr.gov.br/portals/cadernospde/pdebusca/ producoes_pde/2014/2014_ufpr_edespecial_artigo_katia_belasque_bauch.pdf Acesso em: 23/05/2021.

BENDINELLI, R. C.; PRIETO, R. G. ANDRADE, S. G. Inclusão Escolar Redes de Apoio e Políticas Sociais. 2012. Disponível em: https://periodicos.ufsm.br/educacaoespecial/i ssue/view/255 Acesso em: 13 abr. 2021.

BRASIL. Diretrizes nacionais para a educação especial na educação básica. Resolução 02/2001. Brasília: Ministério da Educação. Conselho Nacional de Educação, 2001.

BRASIL. Ministério da Educação. Secretaria de Educação Especial. Política Nacional de Educação Especial na perspectiva da Educação Inclusiva. Brasília: MEC/SEESP, 2008.

COELHO, Caroline Pugliero. Flexibilização curricular no ensino de ciências nos anos iniciais do ensino básico: a experimentação de cromatografia no estudo da fotossíntese para alunos cegos. [dissertação]. Uruguaiana: Universidade Federal do Pampa, 2020.

CRESCENCIO, Renato; BRUNONI, Décio. Análise e caracterização das salas de recursos multifuncionais no ensino fundamental I no município de Aracruz, Espírito Santo. Cad. Pós-

Grad. Distúrb. Desenvolv. São Paulo , v. 18, n. 2, p. 187 201, dez. 2018. Disponível em <h ttp://pepsic.bvsalud.org/scielo.php?script=sci_arttext\&pid=S151903072018000200011\&lng=p t\&nrm=iso>. Acessos em 23 maio 2021. http://dx.doi.org/10.5935/cadernosdisturbios.v18n $2 \mathrm{p} 187-201$.

2008.

Decreto 6.571/2008 que institui o atendimento educacional especializado. Brasília,

FARIAS, Rozeli; SANTOS, Maria Zildelaine de Queiroz. O atendimento educacional especializado (AEE) nas salas de recursos multifuncionais em duas salas da rede municipal do Recife na percepção das professoras do AEE. VII Congresso Nacional de Educação. Maceió, 2020.

GARCIA, Rosalba Maria Cardoso. O conceito de flexibilidade curricular nas políticas públicas de inclusão educacional. In : BAPTISTA, Cláudio Roberto, e col. Inclusão, práticas pedagógicas e trajetórias de pesquisa. Editora Mediação, Porto Alegre, 2007.

Lei no 13.146, de 6 julho de 2015. Institui a Lei Brasileira de Inclusão da Pessoa com Deficiência (Estatuto da Pessoa com Deficiência). Diário Oficial da União, Brasília, DF, 7 jul. 2015. Disponível em:http://www.planalto.gov.br/ccivil_03/_ato2015-

2018/2015/lei//13146.htm. Acesso em 17 de abril de 2021. 
LOPES, Esther. Flexibilização curricular: um caminho para o atendimento de aluno com deficiência, nas classes comuns da Educação Básica. Curitiba: Secretaria de Estado da Educação/Programa de Desenvolvimento Educacional/PDE, 2008.

MEC. Portaria Normativa $\mathbf{n}^{\circ}$ 13, de 24 de abril de 2007, que dispõe sobre a criação do "Programa de Implantação de Salas de Recursos Multifuncionais". Brasília, 2007.

MEC/SEESP. Presidência da República. Decreto no 7.611, de 17 de novembro de 2011. Dispõe sobre a educação especial, o atendimento educacional especializado e dá outras providências. Brasília: 2011.

Ministério da Educação. Resolução n.ํ 4, de 02 de outubro de 2009. Institui Diretrizes Operacionais para o Atendimento Educacional Especializado na Educação Básica, modalidade Educação Especial. Brasília: SEESP, 2009.

Ministério da Educação. Secretaria de Educação Especial. Marcos político-legais da Educação Especial na perspectiva da educação inclusiva. Brasília, DF, 2010.

MIRANDA, T. G. Articulação entre o Atendimento Educacional Especializado e o ensino comum: construindo sistemas educacionais inclusivos. Revista Cocar, Belém: Universidade Federal da Bahia, n. 1, p.81 100, jan. jun. 2015. Disponível em: file:///C:/Users/55559/Downl oads/belfares-614-1350-1-ce.pdf . Acesso em: 28 mai. 2021.

ORRÚ, Sílvia Ester. Redes de Inclusão entre Família e Escola. 2017. Disponível em: https://diversa.org.br/artigos/redes de inclusao entre familia e escola/?gclid=Cj0KCQjwgtWD BhDZARIsADEKwgM0WBKXzrmonb WhFcWfW8HFhWtEAQL1Q4GI ZpXhmkEKeL4YUD4T YaAp-jEALw_wcB Acesso em: 13 abr. 2021.

PASIAN, M. S.; MENDES, E. G.; CIA, F. Salas de Recursos Multifuncionais: revisão de artigos científicos. Revista Eletrônica de Educação, v. 8, n. 3, p. 213-225, 2014. Disponível em: <http://www.reveduc.ufscar.br/index.php/reveduc/article/view/949/366 >. Acesso em: 27 mai. 2021.

Presidência da República. Decreto no 7.611, de 17 de novembro de 2011. Dispõe sobre a educação especial, o atendimento educacional especializado e dá providências. Diário Oficial da União, Brasília, no221, 18 de novembro de 2011. Seção 01.p.12.

REDIG, Annie Gomes, MASCARO, Cristina Angélica Aquino de Carvalho e DUTRA, Flávia Barbosa da Silva. A formação continuada do professor para a inclusão e o plano educacional individualizado: uma estratégia formativa? Revista Diálogos e perspectivas em Educação Especial. São Paulo, 2017

RODRIGUES, S. O; BATISTA, J. O. A importância da sala de recursos multifuncional para alunos público alvo da educação especial. II Congresso Paraense de Educação Especial. Universidade Federal do Sul e Sudeste do Pará - UNIFESSPA, 2015.

ROPOLI, Edilene Aparecida et al. A educação especial na perspectiva da inclusão escolar. A escola comum inclusiva. Brasilia, Ministério da Educação, Secretaria de Educação Especial. Fortaleza: Universidade Federal do Ceará, 2010.

SANTOS, Caroline Vieira de Campos Gonzalez dos; BRAUN, Patrícia. Livrete Pedagógico: Flexibilizações Curriculares para o aluno com Deficiência Intelectual. Programa de Pós Graduação em Ensino na Educação Básica - PPGEB/UFRJ. Rio de Janeiro, 2017.

Disponível em: <https://educapes.capes.gov.br/bitstream/capes/431248/2/Produto\%20Livret 
e\%20Pedag\%C3\%B3gico\%20SANTOS\%20e\%20BRAUN\%202017.pdf > Acesso em 1ํ de fevereiro de 2021.

STAINBACK, W.; STAINBACK, S. Colaboração, rede de apoio e construção de comunidade. In: STAINBACK, S.; STAINBACK, W. (Org.). Inclusão: um guia para educadores. Porto Alegre: ArtMed, 1999. p. 223-232.

UNESCO. Organização das Nações Unidas para a Educação, a Ciência e a Cultura. 48th International Conference on Education - conclusions and recommendations. Genève, IBE, 2008. 


\section{CAPÍTULO 10}

EDUCAÇÃO ESPECIAL INCLUSIVA NO ENSINO SUPERIOR: ABORDAGENS PROBLEMATIZADORA

Fernando Icaro Jorge Cunha

Licenciando em Ciências da Natureza - Universidade Federal do Pampa - Unipampa

Perfil: http://lattes.cnpq.br/149558185211586

E-mail: icaro729@gmail.com

\section{Cristiane De Freitas Rodrigues}

Universidade Federal do Pampa - Unipampa

Perfil: http://lattes.cnpq.br/2590473144333273

E-mail: cris_nutri_@hotmail.com

\section{Cristiane Casagrande Denardin}

Universidade Federal do Pampa - Unipampa

Perfil: http://lattes.cnpq.br/7528612885865102

E-mail: cristianedenardin@unipampa.edu.br

\section{Márcio Da Mota Machado Filho}

Universidade Federal do Pampa - Unipampa

Perfil: http://lattes.cnpq.br/7154020446574377

E-mail: marciotm95@gmail.com

\section{Felix Roman Munieweg}

Universidade Federal do Pampa - Unipampa

Perfil: http://lattes.cnpq.br/2511999351828959

E-mail: felixnieweg.aluno@unipampa.edu.br

\section{Jean Ramos Boldori}

Universidade Federal do Pampa

Perfil: http://lattes.cnpq.br/7498200773581083

E-mail: jeanboldori.aluno@unipampa.edu.br

\section{Janete Mendonça Chrispim Maia}

Universidade Iguaçu - UNIG

Perfil: http://lattes.cnpq.br/7657514122345716

E-mail: Jmendonca.prof@gmail.com

\section{Janete Hickmann}

Rede de Ensino Municipal de São Leopoldo - RS

Perfil: http://lattes.cnpq.br/0461298984464544

E-mail: janete22h@gmail.com

Resumo: Este capítulo é desenvolvido através de uma metodologia de revisão bibliográfica, mensurando a perspectiva de discentes de graduação e pós-graduação, bem como, professoras do ensino superior. O objetivo deste trabalho é avaliar as 
perspectivas que tangem o processo de inclusão no Ensino Superior. As ações afirmativas brasileiras vêm avançando significativamente, garantindo o acesso à graduação e pós-graduação para pessoas com deficiência. Além disso, vale problematizar a permanência dos mesmos na universidade, e averiguar se a acessibilidade ocorre de fato. Os cursos de licenciatura, por exemplo, estão avançando na formação inicial para a educação inclusiva, garantindo que o produto da Educação Básica seja promover a inclusão real. Foi contextualizado neste trabalho sucintamente, a importância do Atendimento Educacional Especializado no Ensino Superior. Além disso, a importância da inserção de discentes com deficiência na iniciação científica.

Palavras-chave: Inclusão; Ensino superior; Graduação; Pós-graduação. 


\section{INTRODUÇÃO}

Desde 2009 até 2019 o número de alunos com matrículas de alunos com deficiência, transtornos globais do desenvolvimento ou altas habilidades/superdotação dobrou de 20.530 (0,34\%) para $48.520 \quad(0,56 \%)$ respectivamente, Segundo Brasil (2020), muito desse aumentos têm vindo devido aos processos seletivos que aumentaram o número de vagas com a expansão universitária tanto na iniciativa pública quanto privada (FERRARI, 2007; BRASIL, 2020), esse aumento proporcionou um com que um público mais variado assim gerando um novo panorama de alunos, destacando aqueles com deficiência intelectuais e outras necessidade especiais (NEE) relacionadas a dificuldade de aprendizagem(Ferrari, 2007), além de alunos de camadas mais pobres da população devido aos processos de políticas de ações afirmativas que visam a inclusão social dessas pessoas que anteriormente não tinha acesso a essa instituições (Da Silva, 2017; Furlan, 2020) Esse novo perfil de aluno gera questões a serem debatidas e o desenvolvimento de ações a favor da inclusão, tanto do ponto de vista político, cultural quanto pedagógico visto que 0 ensino tradicional acaba segregando esse aluno(Furlan, 2020)

No Brasil ainda é muito recente a idéia de alunos NEE participarem aulas inclusivas, essa iniciativa se dão devido a declaração da UNESCO em 1990 a respeito da extinção da segregação escolar, da qual o país se comprometeu em desenvolver um sistema de educação inclusiva, do qual através deste o sistema possibilitou com que ocorresse muitas mudanças estruturais no sistema de ensino tanto através de elaboração e criação de diretrizes nacionais, quanto a mudanças jurídicas(legislativas), assim norteado a e desta forma tornando-o o ensino inclusiva(Ferrari, 2007; Furlan, 2020).

Muito nesse período mudou principalmente no ensino básico porem em instituições de ensino superior essa demanda apenas muito tempo depois chegou e por consequência esbarrou em várias dificuldades tanto relacionadas a tomada da posição das instituições sobre os objetivos e elegibilidades dos alunos de seus cursos, a necessidade de formação pedagógica dos professores do ensino superior para a educação inclusiva e o terceiro o reconhecimento de diferenças e na criação de estratégias para a superação das dificuldade que surgem ao aluno(Furlan, 2020). 
As ações afirmativas têm associação com a busca em combater discriminações através da criação de normas e critérios diferenciados para o acesso a determinados bens ou serviços para grupos específicos normalmente vulneráveis da sociedade, seja devido a origem étnica, racial, social ou de gênero dos indivíduos (Da Silva, 2017). Essas políticas públicas possibilitaram com que candidatos tivessem notas em processos seletivos mais altas desta forma fazendo com que suas chance de cursar o ensino superior fossem maiores (Da Silva, 2017; Da Silva, 2019) porém a grande questão é que além das questões relacionadas ao aluno conseguir ser classificado para à vaga e iniciar o curso muitas adversidades acabam contribuindo para a sua evasão sejam elas devido a um ensino básico precário, seja pela modalidade do curso escolhida ser integral e desta forma comprometendo a renda familiar devido à competição do horário, com este panorama surge a necessidade de criação de ações afirmativas dentro das instituições para permanência deste aluno assim criando os planos de permanência, são planos que tem como foco a subsidiação do aluno para que o mesmo consiga uma renda e desta forma possa se comprometer de maneira integral a sua formação (Da Silva, 2019; Furlan, 2020).

Assim a instituições com todas essas mudanças do seu perfil de seus alunos devem ser questionar a respeito da acessibilidade que é proporcionada tanto sinalização adaptações de espaços de acordo com as melhores práticas de acessibilidade, assim mais inclusiva e justa, seja elas através de projetos de mobilidade urbana que faça com que a comunidade consiga chegar até as instituições de maneira rápida e eficiente, até mudanças relacionadas a cobranças acadêmica através de mudanças dos planos pedagógicos de curso do que ao invés de focar apenas nos conhecimentos técnicos a serem passado respeitem a características individuais desta forma respaldando no senso comum e no empirismo, para que desta forma possa diminuir as dificuldades de aceitação das diferenças entre as pessoas aprendendo a respeitá-las desta forma formando indivíduos e não apenas profissionais (Viana, 2010; Da Silva, 2017; Da Silva, 2019; Furlan, 2020).

Através destes relatos várias são as ações afirmativas que tem por objetivo estimular a permanência de alunos NEE, deficiência intelectuais e grupos vulneráveis as instituições de ensino superior entre elas se destacam algumas como a Universidade Federal de Juiz de Fora que disponibiliza atendimento individual dos alunos com o intuito de diminuir a deficiências pedagógicas; estimular e facilitar a 
permanência do aluno, já Universidade Federal de Viçosa que tem um programa de tutoria nas ciências básicas, que tem por objetivo apoiar o aluno que ingressa na instituição com deficiência nos conhecimentos prévios na área de ensino cursada(Da Silva, 2019), ou como a Universidade Federal do Pampa que conta com Núcleo de Desenvolvimento Educacional - NuDE na UNIPAMPA que conta com uma equipe multiprofissional, constituída por Pedagogo, Assistente Social e Técnico em Assuntos Educacionais, de outros profissionais, que tem por finalidade integrar-se nas ações de acolhida e atendimento à Comunidade Acadêmica, através do acompanhamento dos processos educacionais e estudantis e do desenvolvimento do trabalho pedagógico, com vistas à qualificação dos processos de ensino e de aprendizagem; bem como integrar e participar de ações de assistência estudantil, a fim de contribuir para o desenvolvimento dos estudantes com vistas à permanência e conclusão do curso. (Unipampa, 2021).

Todas essas ações têm por finalidade o aumento do acesso desses grupos para que desta forma consigam-se diminuir as mazelas da sociedade relacionadas a discriminações políticos, inferioridade de gêneros, raças ou habilidades ou cultura, assim contribuindo para que as instituições de ensino superior consigam formar profissionais com senso crítico capazes de se posicionar no lugar do outro, desta forma contribuindo para um melhor entendimento do problema ou situação para o qual foi solicitado e que assim possam ajudar ou contribuir para a resolução de maneira mais eficaz.

\section{INCLUSÃO ESCOLAR NA GRADUAÇÃO}

A lei de cotas propagou o acesso de pessoas com deficiência no ingresso ao Ensino Superior, especificamente nos cursos de graduação. As vagas reservadas, garantem um direito essencial para a equidade social. Mas além do que garantir a vaga, é necessário atrair e articular subsídios que efetivem a permanência dos tais no Ensino Superior (BRASIL, 2012).

Art. 3ํㅡ Em cada instituição federal de ensino superior, as vagas de que trata o art. $1^{\circ}$ desta Lei serão preenchidas, por curso e turno, por autodeclarados pretos, pardos e indígenas e por pessoas com deficiência, nos termos da legislação, em proporção ao total de vagas no mínimo igual à proporção respectiva de pretos, pardos, indígenas e pessoas com deficiência na população da unidade da Federação onde está instalada a instituição, 
segundo o último censo da Fundação Instituto Brasileiro de Geografia e Estatística - IBGE (BRASIL, 2012, Art. 3).

Os docentes que atuam na docência da graduação, devem garantir que os alunos sejam incluídos de fato, na literatura é possível encontrar todos os fundamentos e legislações que norteiam metodologias e práticas que demandam a necessidade à inclusão.

\begin{abstract}
A inclusão social como fator fundamental para equidade e desenvolvimento da sociedade brasileira, hoje, requer que os educadores estejam, permanentemente, informados sobre os processos educacionais $e$ necessidades especiais das pessoas com deficiência e das possibilidades das Tecnologias de informação e Comunicação (TIC). Nessa perspectiva, a criação e aperfeiçoamento de tecnologias assistivas proporcionam à pessoa com deficiência maior independência, qualidade de vida e inclusão social, pois proporcionam a ampliação de sua comunicação, mobilidade, controle de seu ambiente, facilitando o desenvolvimento de habilidades e de condições para seu aprendizado, trabalho e integração com a família, amigos e sociedade (ROCHA; MIRANDA, 2009, p. 27).
\end{abstract}

Rocha e Miranda (2009) discorrem sobre a necessidade de aplicar os fundamentos da Educação Especial Inclusiva desde a formação inicial no magistério superior em função da diversidade. "A formação de professores no magistério superior para áreas que não são pedagógicas, geralmente, não conta com disciplinas que preparem para o ensino em seus currículos. Por isso, os professores desconhecem as questões relacionadas às necessidades educativas especiais" (ROCHA; MIRANDA, 2009, p. 35).

\title{
3. INCLUSÃO ESCOLAR NA PÓS-GRADUAÇÃO
}

Nos últimos anos, têm ocorrido enormes avanços teóricos e políticos relacionados aos processos de inclusão escolar das pessoas com deficiência auditiva, física, intelectual, visual, Transtornos do Espectro Autista (TEA) e altas habilidades ou superdotação. A inclusão de alunos com deficiência ou transtornos gera uma preocupação cada vez mais presente nas instituições de ensino e na sociedade de modo geral. Em geral, esse tema é tratado de forma muito específica, visando atender, quase que exclusivamente, às deficiências intelectuais, sensoriais ou físicas e aos distúrbios globais do desenvolvimento. Entretanto, no que se refere à efetivação da inclusão escolar e ao sucesso dos processos de ensino e de aprendizagem de alunos com necessidades educacionais especiais, ainda temos algumas barreiras relacionadas aos níveis de ensino onde a inclusão é efetivamente realizada e a 
formação inicial e continuada de professores em todos os níveis de ensino, não somente no ensino fundamental e médio (Santos, 2010).

De acordo com a Lei de Diretrizes e Bases da Educação Nacional n. 9.394/96, a Educação Especial caracteriza-se como modalidade de educação escolar, oferecida preferencialmente na rede regular de ensino, para educandos portadores de necessidades especiais. Assim, a rede pública e privada de ensino deve acolher esses alunos, inserindo-os no convívio com as outras crianças e oferecendo-lhes as mesmas oportunidades de ensino e aprendizagem. Nesse contexto, observamos que a inclusão escolar está bem definida no ensino fundamental e médio, uma vez que os alunos com deficiência intelectual passam a integrar as instituições regulares de ensino públicas e privadas. Porém, devemos pensar em qual o destino destes alunos quando saem do ensino médio e almejam entrar em uma Universidade, ou posteriormente irem mais longe fazendo uma Pós-graduação. Será que temos esta mesma atenção e cuidado para estes indivíduos nestes níveis de ensino?

No que diz respeito aos alunos com necessidades especiais observamos cada vez mais que as medidas de inclusão social e escolares estão tirando estes indivíduos de casa e possibilitando o avanço nos níveis de ensino, o que poderá promover mais oportunidades de emprego e qualidade de vida. As pessoas com necessidades especiais estão cada vez mais almejando entrar para uma universidade, se especializar através de um curso superior e até uma pós-graduação. Observamos a cada ano um aumento no número de inscritos e aprovados em cursos de graduação de universidades públicas e privadas.

Pode-se afirmar que nos últimos anos houve grande avanço no que se refere ao Direito Educacional, particularmente em relação a grupos reiteradamente excluídos das oportunidades escolares, tais como os negros, os indígenas e as pessoas com deficiências. No entanto, as mudanças internas não ocorrem por imposição legal, a despeito da importância da legislação contemplando anseios da sociedade em cada momento histórico. Daí a importância e necessidade de se conhecer e analisar os elementos ideológicos e comportamentais da cultura impregnada na sociedade que deseja, de fato, a inclusão social dos sujeitos que a compõem (Branco \& Leite, 2016). E, como comenta Carvalho (2003, p. 47), "atitudes não se modificam num estalar de dedos. Decorrem de um longo processo, geralmente sofrido e com obstáculos afetivos e cognitivos a serem superados". 
Sobre essa questão é oportuno lembrar, também, que "a aplicação da norma igualitária para as situações concretas implica o conceito de equidade [...] que toma a norma igualitária e, ao ser aplicada em um caso concreto, elimina uma discriminação e introduz uma relação mais justa entre os sujeitos" (Cury, 2005, p. 45). E esse é o princípio fundamental da inclusão como nós a entendemos. Uma política de inclusão escolar que respeita e reafirma a igualdade de direitos e assegura a educação escolar para todos há de ser aquela que não pratique uma inclusão selvagem, como qualificou Mazzotta (2008), significando esta uma imposição de matrícula e permanência de todos os alunos em estruturas escolares supostamente idênticas forjando a garantia da igualdade das condições para a escolarização, desconsiderando necessidades especiais de recursos, suportes e serviços especializados para significativos segmentos da população escolar. Mazzotta (2008) reitera que a política educacional há de ser aquela que implanta e implementa condições reais de acesso, permanência e sucesso na escola praticando a inclusão com responsabilidade a fim de incluir todos em escolas de qualidade, contando com os recursos correspondentes às suas necessidades escolares.

Portanto, podemos afirmar que hoje temos a inclusão na forma de cotas em todas as esferas do ensino, inclusive na graduação, e mais recentemente na pósgraduação. Na Universidade Federal do Pampa, a inclusão de cotas nos processos seletivos da pós-graduação é recente, iniciando em 2019. Sabemos que nem todas as universidades federais possuem esse sistema na pós-graduação, mas acreditamos que a expansão destas é questão de tempo. Porém, a pergunta que ainda permanece é se os programas de pós-graduação e suas formas atuais de avaliação estão preparados, no que diz respeito à estrutura física e de acessibilidade, para receber estes indivíduos com necessidades especiais.

Sabemos que o processo de avaliação da pós-graduação brasileira é rigoroso e que a distribuição de recursos financeiros está intimamente ligada a esta avaliação, muito relacionada a produções e publicações científicas. Portanto, acredito que a inclusão de discentes com necessidades especiais na pós-graduação seja mais difícil e lenta, uma vez que muito precisará ser adequado e modificado para que isto se torne possível. Além disso, dependendo da área de pesquisa, muitos fatores devem ser levados em consideração, uma vez que nem todos os discentes com necessidades especiais possuem habilidades que possibilitem 0 trabalho $e$ 
desenvolvimento de projetos em laboratórios de pesquisa. Porém, acredito que todas as possibilidades devem ser avaliadas e consideradas, uma vez que o mais importante é possibilitar que sonhos sejam sempre possíveis de serem realizados.

\section{INCLUSÃO NA PESQUISA CIENTÍFICA}

A iniciação científica durante o período de graduação na universidade é um dos passos mais importantes para uma melhor formação acadêmica, a pesquisa e a vivência dentro de um laboratório permitem aproximar a teoria aprendida em sala de aula com práticas presentes nos ensaios realizados dentro do laboratório, este conjunto gera um maior aprendizado por parte dos alunos. A universidade e a iniciação científica representam um processo de cidadania, pois ela desencadeia inúmeras ações sociais como: oferecimento de bolsas de estudos, participação em congressos científicos nacionais e internacionais e desenvolvimento de pesquisas relevantes à sociedade (ADDOR, 2016).

O ensino, pesquisa e extensão permitem a criação e divulgação de novos conhecimentos, de forma que a pesquisa irá desvendar dúvidas e problemas relacionados a determinado tema, este será transformado em um conhecimento, repassado para os alunos no ensino e aplicados em âmbito social pela extensão, sendo importantes para o processo de formação pessoal e capaz de solucionar problemas socialmente relevantes (Mazzilli, 2011). Desta forma, a universidade além de servir como sede para grupos de pesquisa, atua como uma divulgadora da ciência (Addor, 2016).

A universidade e os grupos de pesquisa como fontes de conhecimento e inclusão, devem desenvolver planos de ação capazes de abranger todas as diferenças entre os sujeitos que constituem a sociedade. A informação que é repassada deve ser acessível a todos, atendendo suas limitações visuais, motoras ou auditivas, tendo em vista que estes sujeitos, muitas vezes, não possuem infraestrutura própria que os permitem acessar este tipo de informação de maneira facilitada (Andrade et al., 2016). A acessibilidade digital, na forma de sinais, sons e linguagens que o sujeito receptor seja capaz de decodificar, permite que os usuários sejam aptos a compreender todo o conhecimento sem prejuízos, contribuindo para que a pesquisa 
científica possa ser pesquisada e acessada nos bancos de dados por todos, pessoas com deficiência e não deficientes (Ignácio, 2007).

A acessibilidade estrutural, no ambiente de trabalho, também deve ser avaliada, para isto considera-se a criação de trajetos acessíveis, adequação de prédios e laboratórios com presença de barras de apoio e pisos adaptados para evitar a derrapagem, facilitando a movimentação de pessoas com deficiência física. No âmbito humano, torna-se essencial para a universidade a presença de um intérprete de libras e materiais contendo linguagem em braille, direcionado para os sujeitos com deficiência visual e auditiva (Ciantelli \& Leite, 2016).

A tecnologia está sendo utilizada, cada vez mais, como uma aliada no processo de inclusão, pois a tecnologia é capaz de criar novos métodos que ultrapassam barreiras e limitações físicas dos sujeitos (Bruno \& Nascimento, 2019). A ampliação de metodologias acessíveis irá permitir que sujeitos com deficiências sejam capazes de utilizar interfaces adaptadas, como por exemplo: equipamentos que sejam capazes de responder e realizar tarefas partindo de um comando com voz (ALSHU'EILI et al., 2011) ou reconhecimento de movimentos (HULSURE et al., 2011).

No Brasil, estudos estão sendo desenvolvidos visando uma maior acessibilidade para as pessoas com deficiência, como a criação de uma interface onde a movimentação do mouse seja controlada pelo movimento dos olhos do usuário, projeto desenvolvido pela professora Annabell Del Real Tamariz da Universidade Estadual do Norte Fluminense Darcy Ribeiro (UENF) (RIBEIRO, 2020).

A criação de interfaces adaptadas que sejam de simples compreensão e utilização é a principal dificuldade no processo de desenvolvimento destas ferramentas por meio da inteligência computacional. Com o passar dos anos e o avanço das pesquisas, tende-se a diminuir, cada vez mais, a dificuldade de acesso das pessoas com deficiência a equipamentos e ambientes de trabalho (MOREIRA; SILVA, 2014).

\section{ACESSIBILIDADE E FORMAÇÃO PARA INCLUSÃO ESCOLAR NO ENSINO SUPERIOR}

O ensino superior é a modalidade mais abrangente em desenvolvimento de ensino, pesquisa e extensão. Entretanto, suas aplicações e ofertas de acessibilidade, 
ainda deixam a desejar. Muitos alunos que possuem necessidades educacionais especiais, não atingem a inclusão efetiva da forma correta.

Isso é ainda mais grave, quando pensamos no sentido de ensino superior articulado nas três dimensões. Será que os alunos que necessitam de tal acessibilidade atingem os mesmos privilégios, e são incluídos de modo a realizar todas as atividades desejadas, sem ter a sua necessidade especial como desafio? É válido ressaltar que os estudos atuais e a formação de novos educadores especiais, contribuem para que esse desenvolvimento venha a acontecer mais rapidamente.

As condições de acesso e permanência do aluno com deficiência no ensino superior não implica apenas a construção de espaços fisicamente acessíveis, mas também recursos pedagógicos (livros, equipamentos, instrumentos etc.), informações para a comunidade técnico-administrativa, instruções e/ ou capacitação aos professores e apoio institucional. Portanto, há que se proporcionar uma mudança no modus operandi de uma instituição no seu fazer tradicional tanto no ensino, na pesquisa e na extensão quanto na infraestrutura oferecida a toda a comunidade docente, discente e administrativa. (POKER; VALENTIM; GARLA, 2018, p. 129).

A partir da década de 1990, o Brasil propagou uma série de resoluções, diretrizes e normativas que orientam os subsídios didático-pedagógicos para direcionar a inclusão escolar. Estes direcionamentos, foram fundamentais para que as políticas educacionais fossem amparadas em igualdades, garantindo que diferentes estudos e pesquisas, fossem submetidas ao foco de incluir os educandos (Ibid., p. 128).

Dentro do grupo de alunos público-alvo da Educação Especial estão os discentes com deficiência que, historicamente, foram excluídos da educação escolar no contexto regular de ensino e passam a ser incluídos nesse processo educativo, sendo mais um alvo de políticas públicas educacionais na perspectiva da inclusão educacional. (PRAIS; ROSA, 2021. p. 4).

A formação de educadores especiais vem sendo cada vez mais aprimorada em uma riqueza de formações generalistas e específicas. Tal interdisciplinaridade entre as áreas da educação especial inclusiva, em oferta de formação, contribui para que os professores municipais e estaduais, apliquem os conceitos em seus respectivos setores de atuação.

Art. 74 - A preparação para o exercício do magistério superior se faz, em nível de pós - graduação, em programas de mestrado e doutorado, acompanhados da respectiva formação didático - pedagógica, inclusive de modo a capacitar o uso das modernas tecnologias do ensino (SAVIANI, 1998, p. 144). 
A Lei de Cotas foi regulamentada através da Lei Federal n 13.409, de 28 de dezembro de 2016 (BRASIL, 2016). "é um instrumento legal que representa uma medida paliativa para legitimar o direito à Educação Superior dos alunos autodeclarados pretos, pardos, indígenas e/ou com deficiência diante da necessidade da consolidação de uma educação inclusiva" (PRAIS; ROSA, 2021. p. 4).

\begin{abstract}
A Educação Especial é compreendida como campo de conhecimento e modalidade transversal de ensino que perpassa todos os níveis, etapas e modalidades. Cabe a ela realizar o atendimento educacional especializado e disponibilizar o conjunto de serviços e estratégias específicas; como na organização de recursos pedagógicos e de acessibilidade, que eliminem as barreiras e possibilitem o acesso ao currículo, à comunicação e aos espaços físicos, considerando as necessidades de cada aluno/a e, promovendo a formação integral com vistas à autonomia e independência, que favoreçam a conclusão da escolarização nos diversos níveis de ensino dos alunos com deficiência, transtornos globais do desenvolvimento e altas habilidades/superdotação, além da sua interação no contexto educacional, familiar, social e cultural. (ANACHE; ROVETTO; OLIVEIRA, 2014, p. 300).
\end{abstract}

Em concordância com os termos supracitados, é possível refletir sobre a importância do atendimento educacional especializado (AEE) no ensino superior. Principalmente, quando pensamos na garantia de cursar todo este processo e concluir. Evitando que a necessidade educacional especial seja o motivo da exclusão ou evasão do ensino superior.

Portanto, o ensino superior deve garantir a acessibilidade necessária para que os alunos sejam incluídos no ambiente escolar. $O$ atendimento educacional especializado, deve ser ofertado para atingir a "linguagem especial" adequada para o educando. Profissionais capacitados na Língua Brasileira de Sinais (libras) ou braile, devem ser garantidos para alunos que necessitem de adaptações para desempenhar seu papel como discente no ensino superior.

O discente que necessita destas adaptações, deverá ser acompanhado e gozar de todos os benefícios e inserções que um discente regular, seja no ensino, pesquisa ou extensão. Neste sentido, o ensino superior, estará sendo regulamentado em uma igualdade e homogeneidade.

\title{
6. CONSIDERAÇÕES FINAIS
}

Ao longo deste texto, buscou-se avaliar a Educação Especial Inclusiva no ensino superior. Sabemos que ingressar em uma universidade, seja ela pública ou particular, não é tarefa fácil, tanto na graduação como na pós-graduação o aluno 
encontrará dificuldades no decorrer do curso. Embora a procura por esses cursos tenha aumentado muito no decorrer dos anos, uma vez que, políticas públicas voltadas para o ensino superior possibilitam a entrada na faculdade, ainda assim, existem algumas situações problemáticas que fazem com que haja evasão, tais como: a modalidade do curso e a formação do aluno. Sendo assim, o aluno com necessidades especiais precisará de um grande apoio para permanecer na "vida acadêmica".

Considerando as discussões a respeito da educação inclusiva, tanto na graduação como na pós-graduação observou-se que há necessidade das universidades se adequarem para receber seus alunos. Porque o aluno com necessidade especial irá precisar de todo um apoio didático e pedagógico para que consiga continuar os estudos. Destacou-se, ainda, que algumas instituições de ensino têm um preparo relacionado à inclusão. Mostrou, também, que a Universidade Federal do Pampa conta com uma equipe pedagógica preparada para a educação especial e inclusiva. Ainda com respeito à inclusão foram destacados diversos autores como Viana, 2010; Da Silva, 2017; Da Silva, 2019; e Furlan, 2020.

Outra questão relevante é a inclusão na pesquisa científica, porque o aluno precisará conciliar teoria e prática e será através das pesquisas que isso se concretizará. Sendo assim, este é outro requisito em que a universidade também deve estar preparada, com planos de ação capazes de abranger todas as diferenças. Uma questão fortemente debatida do que deve constar nas faculdades foi a acessibilidade, não somente no uso restrito da palavra, mas também a acessibilidade digital e a acessibilidade estrutural.

Outro fator importante diz respeito à formação de novos educadores especiais. Esses educadores bem formados podem contribuir na acessibilidade do aluno com necessidades especiais. Também será o momento de fazer cumprir as leis voltadas para o educando, aplicando assim medidas que possam diminuir a evasão, garantir aprendizagem e respeitar as diferenças. Dessa forma, de acordo com (ANACHE; ROVETTO; OLIVEIRA, 2014, p. 300), "deve-se promover a formação integral com vistas à autonomia e a independência que favoreçam a conclusão da escolarização nos diversos níveis de ensino dos alunos com deficiência".

Em suma, procurou-se refletir sobre os problemas que podem ser encontrados por uma pessoa com necessidade especial que está ou deseja cursar a graduação, a 
pós-graduação e a pesquisa científica. Necessita-se, ainda, de muitas mudanças para que as universidades possam oferecer uma educação especial e inclusiva. Embora algumas universidades já estejam se adaptando para receber o diferente, ainda há muito o que ser feito para que haja uma melhora satisfatória. 


\section{REFERÊNCIAS}

ALSHU'EILI, H., Gupta, G. Sen, \& Mukhopadhyay, S. (2011). Voice recognition based wireless room automation system. $20114^{\text {a }}$ International Conference on Mechatronics (ICOM). https://doi.org/10.1109/ICICPI.2016.7859679

ALSHU'EILI, H.; GUPTA, G. S.; MUKHOPADHYAY, S. Voice Recognition Based Wireless Room Automation System. 4를 International Conference on Mechatronics (ICOM), 2011. https://doi.org/10.1109/ICICPI.2016.7859679

ANACHE, Alexandra Ayach; ROVETTO, Sabrina Stella Maris; OLIVEIRA, Regiane Alves de. Desafios da implantação do atendimento educacional especializado no Ensino Superior. Revista Educação Especial, v. 27, n. 49, p. 299-312, maio/ago. 2014. Disponível em: https://periodicos.ufsm.br/index.php/educacaoespecial/article/view/9037.

ANDRADE, S.; LUCAS, E. R. O.; NASCIMENTO, M. J. Acessibilidade Para Usuários Da Informação Com Deficiência: Um Estudo De Artigos Em Biblioteconomia E Ciência Da Informação. Biblionline 11 (1): 1-20. 2011.

BRASIL. Lei Federal $n^{\circ}$ 13.409, de 28 de Dezembro de 2016, que altera a Lei $n^{\circ} 12.711$ de 29 de Agosto de 2012 para dispor sobre a reserva de vagas para pessoas com deficiência nos cursos técnico de nível médio e superior das instituições federais de ensino. Brasília: Presidência da República/Casa Civil/ Subchefia para Assuntos Jurídicos, 2016. Disponível em: http://www.planalto.gov.br/ccivil_03/_ato2015-

2018/2016/lei/L13409.htm. Acesso em: 30 jun. 2020.

BRANCO, Ana Paula Silva Cantarelli; LEITE, Lucia Pereira. Condições de acessibilidade na pós-graduação: um estudo com estudantes de universidade pública. Psicol. educ., São Paulo, n. 43, p. 35 45, dez. 2016. Disponível em<http://pepsic.bvsalud.org/scielo.php?script =sci_arttext\&pid=S1414-69752016000200004\&Ing=pt\&nrm=iso>. acessos em 29 mar. 2021. http://dx.doi.org/10.5935/2175-3520.20160004.

BRUNO, M. M. G.; NASCIMENTO, R. A. L. Política de Acessibilidade: O Que Dizem as Pessoas Com Deficiência Visual. Educação \& Realidade 44 (1): 1-15. 2019. https://doi.org/10.1590/2175-623684848

CARVALHO, R. E. Experiências de assessoramento a sistemas educativos governamentais na transição para a proposta inclusiva. Movimento: Revista da Faculdade de Educação da Universidade Federal Fluminense, Niterói, n. 7, p. 39-59, maio, 2003.

CIANTELLI, A. P. C.; LEITE, L. P. Ações Exercidas Pelos Núcleos de Acessibilidade Nas Universidades Federais Brasileiras. Revista Brasileira de Educação Especial. 22 (3): 41328. https://doi.org/10.1590/S1413-65382216000300008. 2016.

CURY, C. R. J. Os fora de série na escola. Campinas: Armazém do Ipê, 2005.

HULSURE, V. P.; KULKARNI, U. L.; BHOSALE, V. R. View Based Approach for Recognition of Human Movement." International Conference and Workshop on Emerging Trends in Technology 2011, ICWET 2011 - Conference Proceedings, no. Icwet: 153-56. 2011. https://doi.org/10.1145/1980022.1980055 
IGNÁCIO, E. A. Análise Da Acessibilidade Da Informação Digital Pelas Pessoas Com Deficiência Em Sites De Órgãos De Pesquisa Brasileiros. Pontifícia Universidade Católica De Campinas. 2007.

MAZILLI, S. Ensino, Pesquisa e Extensão: Reconfiguração Da Universidade Brasileira Em Tempos de Redemocratização Do Estado." Revista Brasileira de Política e Administração Da Educação-Periódico Científico: 205-21. 2011. https://doi.org/10.21573/vol27n22011.24770

MAZZOTTA, M. J. S.; D'ANTINO, Maria Eloísa Famá. Inclusão social de pessoas com deficiências e necessidades especiais: cultura, educação e lazer. Saude soc., São Paulo, v. 20 , n. 2, p. 377389 , June 2011. Available from <http://www.scielo.br/scielo.php?script= sci_arttext\&pid=S0104-12902011000200010\&Ing=en\&nrm=iso>. access on 26 Mar. 2021. https://doi.org/10.1590/S0104-12902011000200010. 


\section{CAPÍTULO 11}

PARÂMETROS DE SUMA IMPORTÂNCIA NA EDUCAÇÃO ESPECIAL INCLUSIVA: AS INTER-RELAÇÕES SOCIAIS INFLUENCIAM?

Cristiane De Freitas Rodrigues

Universidade Federal do Pampa - Unipampa

Perfil: http://lattes.cnpq.br/2590473144333273

E-mail: cris_nutri@hotmail.com

Fernando Icaro Jorge Cunha

Universidade Federal do Pampa - Unipampa

Perfil: http://lattes.cnpq.br/149558185211586

E-mail: icaro729@gmail.com

Janete Mendonça Chrispim Maia

Universidade Iguaçu - UNIG

Perfil: http://lattes.cnpq.br/7657514122345716

E-mail: Jmenconca.prof@gmail.com

Márcio Da Mota Machado Filho

Universidade Federal do Pampa - Unipampa

Perfil: http://lattes.cnpq.br/7154020446574377

E-mail:marciotm95@gmail.com

\section{Adriana Da Silva Biavaschi}

Universidade Federal do Pampa

Perfil: http://lattes.cnpq.br/6790810594771617

E-mail: fereadri2002@gmail.com

Maria José Baltar De Azambuja

Professora da Secretaria Municipal de Porto Alegre-RS

Perfil: http://lattes.cnpq.br/8379431150091984

E-mail:mj.azambuja@bol.com.br

Cristiane Casagrande Denardin

Universidade Federal do Pampa - Unipampa

Perfil: http://lattes.cnpq.br/7528612885865102

E-mail: cristianedenardin@unipampa.edu.br

Jean Ramos Boldori

Universidade Federal do Pampa

Perfil: http://lattes.cnpq.br/7498200773581083

E-mail: jeanboldori.aluno@unipampa.edu.br

Caroline Pugliero Coelho

Universidade Federal do Pampa - UNIPAMPA/Campus Uruguaiana

Perfil: http://lattes.cnpq.br/1138015620367845 
E-mail: carolinecoelho.aluno@unipampa.edu.br

\title{
Simone Baltazar Ferras
}

Professora da rede municipal de Porto Alegre

Perfil: http://lattes.cnpq.br/8571943548255077

E-mail: simoneferras@gmail.com

\section{Osmar Senador Mendonça Júnior}

Escola Estadual de Ensino Fundamental Santa Inês - Alegrete/RS

Perfil: http://lattes.cnpq.br/8616680212649832

E-mail: jrbiol1507@gmail.com

\section{Salete Pereira Zanella}

Universidade Federal de Pelotas - UFpel

Perfil: http://lattes.cnpq.br/9831463605016855

E-mail: soldreher@gmail.com

\author{
Janete Hickmann \\ Rede de Ensino Municipal de São Leopoldo - RS \\ Perfil: http://lattes.cnpq.br/0461298984464544 \\ E-mail: janete22h@gmail.com
}

Resumo: Este capítulo é uma revisão bibliográfica que discorre sobre a importância das inter-relações sociais, em parâmetros que os autores consideram importantes para a educação especial inclusiva. Incluir sem comunicação, acaba gerando desunião e exclusão. Neste sentido, é importante a aliança da gestão da escola, do corpo docente, dos órgãos públicos e, principalmente, a participação familiar. Essa participação dos pais no processo educativo, torna-se indispensável para facilitar a comunicação entre a escola e promover o desenvolvimento do processo de ensinoaprendizagem. Os docentes devem abordar temas transversais, que garantem aos alunos um aprendizado eficaz e inclusivo, possibilitando conviver com suas diferenças e desconstruindo padrões e conceitos. Valorizando, a inserção dos alunos com deficiência, não só no âmbito escolar, mas também na comunidade, de forma respeitosa, inclusiva e cidadã. Essa sensibilidade de percepção é de grande valia para intervir de maneira correta, sob alguma condição adversa de preconceito e exclusão, desconstruindo paradigmas e possibilitando atingir um equilíbrio socioeducativo inclusivo. Por isso, é um grande desafio para a escola promover a implementação dos projetos inclusivos, pois requerem uma integração de conteúdos programados, debates construtivos e empenho de toda comunidade escolar a fim de formar alunos com senso moral, ético e empatia ao próximo.

Palavras-chave: Parâmetros; Inter-relações sociais; Respeito; Comunicação. 


\title{
1. INTRODUÇÃO
}

O fomento das inter-relações no ambiente educacional inclusivo além de oportunizar uma aprendizagem colaborativa, proporciona ao aluno com deficiência, o desenvolvimento de suas habilidades sociais em um processo de humanização. Nesse sentido, é essencial que os professores, famílias, demais estudantes e a comunidade escolar como um todo, "se adaptem ao meio que a criança inclusa está inserida, dando a devida importância para tamanha contribuição na vida escolar dessa criança" (SILVA; ARRUDA, 2014, p. 01).

No Brasil, o estudante com deficiência está matriculado na escola comum, porém, o trabalho do Atendimento Educacional Especializado vai propiciar a identificação das especificidades e potencialidades educacionais de cada aluno de forma articulada com os docentes da sala regular.

O Parecer CNE/CEB 17/2001 destaca que a política de inclusão de alunos com deficiência na rede regular de ensino, "não consiste apenas na permanência física desses alunos junto aos demais educandos, mas representa a ousadia de rever concepções e paradigmas, bem como desenvolver o potencial dessas pessoas, respeitando suas diferenças e atendendo suas necessidades" (BRASIL, 2001, p. 12).

Logo, quando a educação especial e inclusiva propõe um ambiente de formação que vai além da sala de aula, pautado nas inter-relações sociais e na troca de experiências e afetividades, os alunos com deficiência iniciam um processo de construção e/ou ressignificação identitária. Nas palavras de Gallo, 2002:

\begin{abstract}
A formação do aluno jamais acontecerá pela assimilação de discursos, mas sim por um processo microssocial em que ele é levado a assumir posturas de liberdade, respeito, responsabilidade, ao mesmo tempo em que percebe essas mesmas práticas nos demais membros que participam deste microcosmo com que se relaciona no cotidiano. Uma aula de qualquer disciplina constitui-se, assim, em parte do processo de formação do aluno, não pelo discurso que o professor possa fazer, mas pelo posicionamento que assume em seu relacionamento com os alunos, pela participação que suscita neles, pelas novas posturas que eles são chamados a assumir. É claro que esse processo não fica confinado a sala de aula; todas as relações que o aluno trava no ambiente escolar - com outros alunos, com funcionários, com o staff administrativo, enfim, com toda a comunidade - são passos na construção de sua personalidade (GALLO, 2000, p. 20).
\end{abstract}

Além disso, a participação da família como mediadora no processo educativo pode enriquecer e potencializar a aprendizagem do aluno incluso, pois é no meio familiar que "a criança aprende a administrar e resolver os conflitos, a controlar as 
emoções, a expressar os diferentes sentimentos que constituem as relações interpessoais, a lidar com as diversidades e adversidades da vida" (DESSEN; POLONIA, 2007, p. 23).

Outro parâmetro imprescindível para uma efetiva inclusão escolar, leva em consideração os aspectos afetivos como mediadores do trabalho docente. Trabalhar a inteligência interpessoal dos estudantes utilizando os espaços de convivência comum da escola como: pátio, quadra, refeitório, biblioteca, jardim, sala de aula e outros, promove a integração do grupo e estabelece vínculos de afetividade, cooperação e respeito mútuo (LUCENA, 2020).

Nesse sentido, Dessen e Polonia (2007, p. 27) destacam que:

\begin{abstract}
Os laços afetivos, estruturados e consolidados tanto na escola como na família permitem que os indivíduos lidem com conflitos, aproximações e situações oriundas destes vínculos, aprendendo a resolver os problemas de maneira conjunta ou separada. Nesse processo, os estágios diferenciados de desenvolvimento, característicos dos membros da família e também dos segmentos distintos da escola, constituem fatores essenciais na direção de provocar mudanças nos papéis da pessoa em desenvolvimento, com repercussões diretas na sua experiência acadêmica e psicológica; dependendo do nível de desenvolvimento e demandas do contexto, é possibilitado à criança, quando entra na escola, um maior grau de autonomia e independência comparado ao que tinha em casa, o que amplia seu repertório social e círculo de relacionamento. Neste caso, a escola oferece uma oportunidade de exercitar um novo papel que propiciará mecanismos importantes para o seu desenvolvimento cognitivo, social, físico e afetivo, distintos do ambiente familiar.
\end{abstract}

Portanto, a promoção dessas inter-relações pode ser bastante eficaz para o exercício da cidadania e na superação de casos de preconceito em relação à educação especial e inclusiva, pois a inclusão não se estabelece apenas no ambiente escolar, mas em qualquer espaço que exista convívio social. Para tanto, reforça-se que "o apoio da escola, dos professores, da equipe multidisciplinar, da família e toda a comunidade são de fundamental importância para a participação ativa no processo de aprendizagem e das atividades paralelas à educação inclusiva" (SOUZA; CUNHA, 2019, p. 205).

Assim, considerando a relevância das inter-relações sociais no contexto familiar e escolar, este artigo propõe uma revisão de literatura acerca das implicações de importantes parâmetros na educação especial e inclusiva, vislumbrando a qualidade do ensino-aprendizagem. 


\section{A COMUNICAÇÃO ENTRE OS PAS E A ESCOLA E O APOIO FAMILIAR}

Em 1960 a maioria dos médicos recomendava que crianças com deficiências, especialmente as com deficiência cognitiva grave, fossem separadas de sua família e recolocadas numa instalação projetada para lidar com a "incapacidade". Muitos pais se sentiram pressionados a ceder às recomendações de profissionais médicos, relutando para entregar seus filhos a estas instalações. Promovendo uma reformulação para intervir, tanto na legislação como em procedimentos, médicos e socioeducativos. De tal maneira que foi possível melhorar as condições e o estilo de vida de crianças com necessidades especiais, tentado ao máximo possível se adequar aos padrões da sociedade na década de 70 (ARMON; TERRY, 2014; ROGALSKI, 2010).

Mas, foi em 2010, que descobriram que a união entre pais e professores faria toda diferença no ensino-aprendizado de crianças com necessidades especiais. Este elo entre família e educadores se tornaria eficaz, desde que ambos conseguissem encontrar valores socioeducacionais em comum. Almejando melhorias nos métodos de intervenção educativa, objetivando a inclusão do aluno na comunidade escolar e na sociedade (SALOMÃO; JESUS; PALÁCIOS, 2017).

Entretanto, foi com o surgimento da escola-novista que foram implementados projetos que atuassem na educação, com embasamento em pesquisas científicas em prol de amenizar danos das desigualdades sociais e estimular a liberdade individual de cada criança (MENDES, 2010). No Brasil, este movimento de medidas socioeducativas foi regulamentado pelo projeto de lei do aluno do público-alvo da Educação Especial (PAEE), que visa a incorporação de ações educacionais destinadas às crianças especiais prestadas pelo professor. Porém estes serviços não estão diretamente centralizados no estudante, o que proporciona certo incômodo de muitos pais, pela falta de direcionamento do projeto. Esses sentimentos de insegurança e insatisfação, acabam dando margem para que os pais procurem alternativas de confortabilidade para seus filhos, como permuta de escolas, buscando outras maneiras de ensino e até mesmo evasão escolar (ARMON; TERRY, 2014).

Por isso, a escola deve estar disposta em promover a educação inclusiva das crianças com necessidades especiais, para que pais se sintam seguros e apoiados neste processo de ensino-aprendizado. Essa comunicação entre pais e escola é de 
extrema importância em vários aspectos, primeiramente a escola deve ser ciente que as crianças especiais são diferentes umas das outras, com suas peculiaridades diferentes e hábitos diferentes. Mas tendo em comum a sensibilidade e percepção que um acolhimento positivo, influencia muito quando adentra no mundo novo, neste caso a escola. Este sentimento de conforto e zelo transcende das crianças para seus pais, passando mais segurança e credibilidade à escola, o que fortalece a comunicação entre familiares e escola (GREY, 2021).

Todas as crianças especiais necessitam de segurança ao adentrar num espaço novo, o novo é algo que eles precisam de adequação e reabilitação. Neste caso o acolhimento no espaço novo se torna extremamente necessário, para que a criança consiga apresentar a mesma segurança e tranquilidade quando está em sua residência. Como foi relatado por uma mãe com filho espectro autista "a criança quando sai de sua zona de conforto apresenta um comportamento extremamente diferente, no caso a casa é um ambiente que ele domina tudo e já a escola é um ambiente novo, tudo completamente diferente com pessoas diferentes". Desta forma é fundamental que a escola promova um acolhimento corretamente com harmonia e tranquilidade, para que a criança seja familiarizada com este ambiente e ele promova a mesma sensação de como estivesse em sua residência (CORBIS, 2019).

A escola também deve apresentar um comprometimento às crianças com necessidades especiais, por meio de uma equipe que se responsabilize, tanto pela criança especial e como pelo bom funcionamento escolar, fortalecendo ainda mais o elo entre pais e escola. "A escola deve possibilitar a presença de uma professora auxiliar que irá auxiliar a criança com necessidade especial com suas atividades e com a comunicação com os outros colegas", foi relatado por um pai com filho Transtorno do Déficit de Atenção com Hiperatividade (TDAH). Esses profissionais devem mostrar preparo consistentes, confiabilidade, competência e assim de tudo sensibilidade em desenvolver tópicos inclusivos de maneira generalista que prevê e torne possível a participação da criança especial (FERRANTE, 2012).

Os profissionais que irão desenvolver atividades inclusivas deverão apresentar conteúdos programados, centralizados e inclusivos referentes às áreas de conhecimento. De tal modo que pais, professores, administradores escolares e colegas todos devem trabalhar juntos para garantir a educação e bem-estar do aluno. De tal modo, que é de suma importância que os profissionais e equipe escolar estejam 
diariamente auxiliando as crianças com necessidades especiais e dialogando com os pais a respeito de seu dia escolar. Por isso, é proeminente que a escola se comunique com a família, tornando a escola um ambiente seguro e socioeducativo (SILVA; ARRUDA, 2014).

De tal modo, que garanta a inclusão dele frente a toda rede de ensino e a permanência do mesmo para sua evolução socioeducativa, evitando assim quaisquer problemas relacionados ao ambiente escolar do estudante (SYRIOPOULOU-DELLI; CASSIMOS; POLYCHRONOPOULOU, 2016). Valorizando ainda mais, o ensino pela inclusão ao perceber que a educação vai além do ambiente escolar, mas em todos os ambientes que haja relações humanas acontecendo entre si (SILVA; ARRUDA, 2014).

As escolas integradoras constituem um meio favorável à construção da igualdade de oportunidades da completa participação. Porém, para ter êxito, requerem um esforço comum, não só dos professores e dos demais profissionais que atuam na escola, mas também dos colegas, pais, famílias e voluntários (ORRÚ, 2017). Um relato de uma gestora da rede de ensino afirma "que uma escola inclusiva, só se tornará inclusiva se toda a comunidade escolar abraçar a causa e os pais optarem por se envolver na vida escolar de seus filhos". Essa comunicação entre os pais e a escola tem papel fundamental na construção do ensino aprendizagem das crianças especiais, porém, sabe-se que este processo ocorre lentamente e exige bastante dedicação (MENDES, 2010).

Mesmo que a geração dos pais seja muito atarefada, cabe à escola disponibilizar outras ferramentas para que haja o engajamento familiar na vida escolar das crianças, sendo por via e-mails, SMS, mídias sociais, reuniões on-line, blogs e aplicativos (BARUAH, 2012). Tudo isso para facilitar e estimular o envolvimento da família, servindo de alicerce na promoção socioeducativa dentro e fora do âmbito escolar, enriquecendo a perspectiva de evolução socioeducativa do aluno com necessidades especiais. Outra forma dos pais se manterem envolvidos nas atividades de seus filhos ocorre por meio do convite dos professores, para integrar a equipe que irá planejar as atividades que serão realizadas. Esse apoio aos professores facilita a intervenção do ensino-aprendizado e estimula o conhecimento destas crianças, principalmente por aprimorar a educação inclusiva (PAULA, 2007).

Entretanto, sabe-se que servir crianças com necessidades especiais não é uma tarefa fácil, muitos detalhes devem se reunir para projetar um programa uma 
educação inclusiva eficaz. A família e escola devem se configurar como partes indissociáveis desta rede, valorizando as diferenças de cada um e considerando como algo próprio da espécie humana, porque ninguém é igual a ninguém e ninguém aprender da mesma maneira (SYRIOPOULOU-DELLI; CASSIMOS; POLYCHRONOPOULOU, 2016). Visando isso, alguns países implementaram o plano educacional individualizado (PEI), centralizado na pessoa com suas experiências e situações de vida, com a abordagem no desenvolvimento do indivíduo como um todo e no aprofundamento de suas relações pessoais e de sua vida em comunidade (TANNÚS-VALADÃO; MENDES, 2018).

Este tipo de educação especial inclusiva é uma estrutura de construção fundamentada sobre relações adversas, trazendo a comunicação com os pais uma ferramenta fundamental na criação e implementação de um PEI ativo. Este programa tem o seu diferencial que são reuniões semanais com pais, professores, equipe auxiliadora (gestão e coordenação), explorando as diferenças de opiniões entre os membros da equipe, em vez de ignorá-los. Essa troca de informações possibilita desenvolver estratégias de resolução dos problemas encontrados e torná-los mais inclusivos. De tal modo, que a execução do que foi planejado, com suas etapas delineadas proporcionam criar um ambiente mais aberto com compartilhamento pessoal e informações sensíveis, estabelecendo um resultado desejado claro e de benefício mútuo ao ensino-aprendizado das crianças (SYRIOPOULOU-DELLI; CASSIMOS; POLYCHRONOPOULOU, 2016).

Para aqueles interessados em ter um relacionamento colaborativo McGoey (2008) sugere que os pais façam uma lista das habilidades e dificuldades de crianças com necessidades especiais para que o professor possa escolher o método mais apropriado de autorrepresentação e estímulo desta criança (ARMON; TERRY, 2019). Os professores devem usar a habilidade de escuta ativa e de fácil entendimento para que os pais se sentiam ouvidos e incluídos na atividade escolar de seus filhos em prol de conseguir medidas socioeducativas em comuns. Do mesmo modo, os pais devem certificar que objetivo de cada tarefa seja clara e interativa para que haja a inclusão de maneira mais correta possível (MCGOEY, 2008).

O apoio familiar para uma criança com necessidade especial é de extrema importância, por meio dele que a criança conseguirá se fortalecer para lidar com aspectos únicos de seu distúrbio. Além de melhorar a administração de seus 
sentimentos até mesmo quando confrontado. Num relato de uma mãe, "o apoio familiar começa pela aceitação da criança com necessidade especial, conhecer suas peculiaridades e emoções, além de estimular o crescimento e o interesse através do reforçador positivo". De tal modo, atitudes que possibilitar junto com a escola a viver em sociedade e uma não aceitação dos grupos sociais e das famílias, muitas vezes levam a pessoa com deficiência a assumir posturas indesejáveis e excludentes, como o isolamento, o que dificulta a sua inclusão no ambiente escolar (SILVIA, 2006).

Ao longo da história a comunicação entre pais e profissionais tem sido repleta de altos e baixos, com conflitos legais e emocionais. Mesmo com a implementação das medidas socioeducativas pela legislação o processo de colaboração entre professores e profissionais, as relações pais / profissionais estão sempre em perigo constante, porque um mal-entendido pode intervir diretamente na eficácia do ensinoaprendizado da criança com necessidade especial (SILVA; ARRUDA, 2014). No entanto, é altamente possível e benéfico a colaboração da relação dos pais e da escola no processo de ensino-aprendizagem para crianças com necessidades especiais, desde que exista uma comunicação mútua de confiança e compreensão. Promovendo um progresso dinâmico e flexível e somente assim, entenderão que toda educação inclusiva possibilita o ser humano interagir diretamente com a sociedade, os quais saberão desenvolver suas competências da melhor forma possível (SYRIOPOULOU-DELLI; CASSIMOS; POLYCHRONOPOULOU, 2016).

\section{CUIDADOS ESPECIAIS: A SENSIBILIDADE DO EDUCADOR}

Incluir é fazer com que o aluno se sinta parte do todo, respeitando suas diferenças e afinidades, mais ainda, fazer com que esse aluno se sinta bem, garantindo um ensino de qualidade. Desta forma, acredita-se que Educação Especial e Educação Inclusiva podem caminhar juntas e, assim, construir uma efetiva prática de inclusão escolar (GIARDINETTO, 2009).

Para que a inclusão seja efetiva acredita-se no afeto e na sensibilização dos professores para com as necessidades do outro. Segundo Souza e Oliveira (2009), a formação do professor para o processo de inclusão escolar deve estar ancorada no reconhecimento do outro. Esse outro outrora negado, aquele que teve sua alteridade 
desfigurada por uma representação de menos valia, de ingênuo e ignorante (SOUZA; OLIVEIRA, 2009).

O professor se constitui como sujeito político-social, na medida em que se identifica com sua prática docente, respeita seu aluno, luta por sua inclusão de forma plena na sociedade e se sensibiliza com a causa do outro.

O processo de se sensibilizar com a causa do outro é estar em um estado de espírito no qual uma pessoa se identifica com outra, se identifica com as necessidades do aluno, presumindo sentir o que o outro está sentindo. (MICHAELIS, 1998).

Para poder entender as necessidades dos alunos, fazer as adaptações curriculares necessárias e efetivar a inclusão é preciso que o educador tenha sensibilidade.

\begin{abstract}
Para que os educadores desenvolvam seu trabalho em sala de aula, atendendo e respeitando as diferentes realidades é importante que sejam sensíveis, aos seus modos de olhar e agir, para que possam sentir as sensibilidades e necessidades do aluno. A contribuição para a formação dos mesmos de forma crítica e criativa, sentindo-se agentes atuantes na formação e transformação do meio em que vivem depende do modo de ver e sentir a educação. (BOTTEGA; RAFFAELLI, 2014).
\end{abstract}

Emoções e sentimentos fazem parte do ser humano e estão intimamente ligados à educação e é por meio do sensível que se constroem as relações entre professores e alunos.

Nestas condições teríamos um humano capaz de redescobrir, reinventar caminhos mais humanos e mais verdadeiros (GADOTTI, 2007).

É papel da escola trabalhar com os valores humanos tais como: diálogo, respeito, afetividade, amor, amizade, solidariedade, dentre tantos outros, a fim de desenvolver a sensibilidade.

O docente precisa ter em mente que para reconhecer as especificidades de alunos em processo de inclusão, é necessário emocionar, pois, a emoção está intimamente ligada a sensibilização.

Dessa forma, segundo Gutierres (2015), podem-se criar meios para que ocorra a conscientização das necessidades que este público apresenta. Para tanto, o emocionar está diretamente ligado nesse processo de sensibilização, pois, de acordo com Maturana (1998, p. 18), "o humano se constitui no entrelaçamento do emocional com o racional".

É importante também que o professor seja sensível à reflexão sobre a temática da inclusão, não permitindo que as especificidades de aprendizagem desse público 
deixem de ser atendidas, bem como seus potenciais não reconhecidos e não estimulados. (GUTIERRES, 2015).

Porém, antes de mais nada, o educador deve ter a sensibilidade de entender que cada ser é único, que nenhuma deficiência é igual e que cada aluno tem necessidades próprias.

\section{COMO LIDAR COM OS PRECONCEITOS?}

Desde a idade medieval que o preconceito existe, nesta época, os povos bárbaros, por não serem de origem grega ou romana, eram escravizados e não eram considerados seres humanos.

$\mathrm{Na}$ idade média existiam os preconceitos religiosos entre cristãos e pagãos, os que eram pagãos foram perseguidos pelos cristãos, daí em diante continuam a surgir várias formas de preconceito tais como: social, étnico, de gênero e principalmente contra pessoas com alguma deficiência.

A educação tem sido, comprovadamente, o caminho mais acertado para combater esse mal que sempre assolou a sociedade. E, buscando o conceito de educação, pode-se proceder a uma análise mais profunda da finalidade educativa e do conteúdo pedagógico das medidas aplicadas tanto para as crianças, adolescentes, bem como no meio em que se convive, seja social ou familiar, utilizando-se inteligentemente das teorias de Kant, Marx e Paulo Freire. (SAMPAIO, 2015).

Em conformidade com o pensamento de um dos maiores pedagogos de nosso país, Paulo Freire, "educação nada mais é que um método capaz de educar para a liberdade, não existindo educador e educando, os seres humanos envolvidos na relação de educação aprenderiam um com o outro, sempre tendo por base o objeto a ser conhecido". (SAMPAIO, 2015, p. 2).

Sendo a escola um lugar de formação e aprendizado, ela se torna uma das grandes responsáveis em combater toda e qualquer forma de preconceito.

Na maioria das vezes, é na escola que surgem o preconceito e a violência nas relações interpessoais que reforçam a exclusão e o desrespeito com seus semelhantes.

Entretanto, "problematizar as situações que envolvem preconceitos, desmistificar suas origens não é tarefa fácil, justamente porque as pessoas imersas 
na vida cotidiana precisam de certa praticidade, de "pragmatismo" para que a vida flua". (CORDEIRO; BUENDGENS, 2012, p. 3).

As raízes do preconceito desenvolvem-se a partir da infância, assim a dificuldade em lidar ou identificar o preconceito envolve nosso processo de formação desde muito cedo, pois fomos cegados pelas práticas sociais preconceituosas, começando pelo convívio na família (Silva, 2005).

A família é a primeira escola da criança, é nela que devemos aprender a ter ações de tolerância, aceitação e respeito com outros seres humanos que fazem parte de nosso convívio.

Os Parâmetros Curriculares Nacionais (PCN ) afirmam que:

[...] é a sociedade, quer queira, quer não, que educa moralmente seus membros, embora a família, os meios de comunicação e o convívio com outras pessoas tenham influência marcante no comportamento da criança. $E$ naturalmente a escola também tem (1997, p. 7).

Ensinar valores para o desenvolvimento moral dos alunos, selecionar conteúdos e metodologias que favoreçam práticas de solidariedade, respeito, amizade, tolerância, convivência, ética, entre outros, é uma das formas de lidar com o preconceito.

Martins (2005, p. 12 ) destaca quatro formas ou abordagens pedagógicas que podem ser utilizadas para o desenvolvimento dos valores nos educandos:

doutrinação dos valores: essa abordagem é a mais antiga das maneiras de educar os alunos em valores. Clarificação dos valores: consiste em ajudar os educandos a tornar claros os valores, assumindo-os e pondo-os em prática. Ocorre por meio da disciplina, do bom exemplo dos professores e do currículo. Julgamento dos valores: essa abordagem defende que existem princípios universais, como tolerância, liberdade, solidariedade e justiça, o mais forte deles, e esses valores constituem os critérios da avaliação moral ou de juízo de valor. Narração dos valores: essa abordagem baseia-se nas histórias pessoais ou coletivas, as quais os alunos contam em sala de aula.

Dessa forma, um trabalho sistemático e crítico em conjunto com a família, na formação de valores de cada aluno, é a melhor maneira de lidar com o preconceito.

O preconceito não deixa de ser um reflexo do pensamento e das atitudes dos adultos, então, ser consciente a respeito de seus próprios preconceitos é o primeiro passo para lidar com os mesmos.

Assim, não só estaremos ensinando aos alunos a não serem preconceituosos, como também serviremos de exemplo para que eles respeitem a diversidade no seu dia a dia. 
$\mathrm{Na}$ escola os professores podem lidar com o preconceito por meio da prevenção, podemos contar histórias que apresentam personagens negros ou índios; fazer teatro de fantoches com bonecos de origem chinesa, africana, européia; colocar nomes originários de outros países nas personagens; promover uma aula sobre a cultura dos países ou de uma determinada raça; ver vídeos sobre outras culturas e raças, (VILARINHO, 2021).

Acima de tudo é preciso que na escola se crie um espaço para o diálogo, que se estabeleça uma cultura de paz, amizade, carinho e respeito às diferenças do outro.

\section{A SOCIALIZAÇÃO DE ALUNOS COM DEFICIÊNCIA: CIDADANIA E RESPEITO}

A temática inclusão educacional, apesar de ser muito atual, ainda gera discussão entre docentes e gestores em diversas esferas do ensino. Apesar de necessária, ainda é fonte de dúvidas, desafios e, também, de inúmeras possibilidades, deixando muitos pontos a serem analisados em busca de um processo inclusivo efetivo.

Pensando dentro das perspectivas do processo de inclusão, ressalta-se a grande importância que o ambiente escolar apresenta para o processo de socialização dos alunos. Pois é na escola que se oportuniza a formação da consciência cidadã, a construção de valores para formar os alunos críticos e reflexivos, como também, respeitosos e atuantes dentro do seu papel para a construção de uma sociedade justa e sem preconceitos.

É na escola inclusiva que pode ocorrer o aprendizado do respeito às
diferenças, e isso significa que estes alunos podem adquirir autonomia frente
ao conhecimento construído socialmente, tendo acesso a ele, o que permitirá
condições para exercerem plenamente sua cidadania (FREITAS, 2011, p.42).

Campbell (2009) afirma que a base de uma educação inclusiva vai além da questão de escolarização é, também, uma questão de direitos humanos, pois sua defesa é contra a segregação de qualquer pessoa por conta de sua deficiência. A visão da inclusão preza pelo respeito às singularidades e a valorização das potencialidades de cada indivíduo. Em suma, a inclusão das pessoas com deficiência apresenta uma visão social, de solidariedade e cidadã.

A concepção da educação vinculada à cidadania implica na compreensão da mesma como um processo dialético, contínuo, histórico, contextualizado, marcado por contradições e pela busca de superação das mesmas. Assim 
entendida, a educação inclusiva insere-se no cenário histórico dos direitos de cada cidadão. Trata-se de direitos tidos como indicadores do progresso social e histórico (FREITAS, 2011, p. 43).

Por muito tempo, as pessoas com deficiência foram consideradas como "doentes" ou incapazes frente aos padrões considerados "normais". Muitas ações e interações sociais Ihes proporcionam desvantagens, sendo que por muito ocupavam um espaço de caridade ou assistencialismo. Essa realidade, ainda percebida, pode ser mudada ao passo das pessoas se conscientizarem de que essas pessoas possuem, apenas, limitações. A inclusão, apenas se tornará viável, pela participação de ações coletivas e sociais, respeitando todos os cidadãos sem distinções (CAMPBELL, 2009).

O paradigma da inclusão social consiste em tornar toda a sociedade um lugar viável para a convivência entre pessoas de todos os tipos e inteligências na realização de seus direitos, necessidades e potencialidades, e a pessoa com deficiência passa a ser vista pelo seu potencial, suas habilidades e outras inteligências e aptidões (CAMPBELL, 2009, p. 193).

Sassaki (2003) explica que o processo de inclusão reflete na construção de uma nova sociedade pois transforma ambientes físicos, espaços internos e externos, adaptação e equipamentos e meios de transporte. Assim, transformando também a mentalidade da sociedade como um todo. Portanto, cabe à sociedade eliminar todas as barreiras físicas, programáticas e atitudinais para que as pessoas com deficiência "possam ter acesso aos serviços, aos lugares, às informações e aos bens necessários ao seu desenvolvimento pessoal, social, educacional e profissional" (SASSAKI, 2003, p. 47).

Ainda Campbell (2009, p. 194) explica que:

A inclusão é a garantia a todos do acesso ao espaço comum da vida em sociedade, uma sociedade mais justa, mais igualitária e respeitosa, orientada para o acolhimento à diversidade humana e pautada em ações coletivas que visem à equiparação das oportunidades de desenvolvimento das dimensões humanas.

A inclusão, em todas as esferas (escolar ou social) precisa ser encarada como uma composição da sociedade, dentro das perspectivas da solidariedade e do respeito às diferenças. É preciso um olhar respeitoso, sem preconceitos ou julgamentos. Enxergar a pessoa com deficiência sem menosprezos, entender que apesar de suas limitações ela tem suas capacidades que precisam ser enaltecidas. Campbell (2009, p. 197) afirma que "uma sociedade inclusiva é aquela que assume coletivamente o compromisso de respeitar a diversidade". 
Respeitar o próximo é reconhecê-lo como um ser de igual valor, independentemente de limitações físicas, intelectual, econômica ou social. Este conceito torna-se uma tônica e uma exigência da sociedade, por que os chamados "excluídos" não são diferentes e, ao mesmo tempo, somos todos diferentes, mas, no reino das diferenças, o que deve ter valor é a diversidade (CAMPBELL, 2009, p. 197).

Em tese, a socialização da pessoa com deficiência, dentro ou fora do ambiente escolar é uma questão atrelada à cidadania, ao trabalho com os valores e conceitos de diversidade e de respeito às diferenças. Uma sociedade justa requer um olhar sem preconceitos a qualquer indivíduo, a partir daí teremos um processo inclusivo respeitoso e eficiente.

\section{CONSIDERAÇÕES FINAIS}

Neste artigo, refletimos sobre os parâmetros que norteiam a educação especial e inclusiva. Argumentou-se sobre a influência das inter-relações sociais: a família, a escola, o apoio familiar, e a sensibilidade do educador. Apresentou propostas sobre como lidar com o preconceito na escola. Por fim, tratou-se da cidadania e o respeito ao lidar com alunos com deficiência.

É importante salientar que o tema foi muito pertinente, uma vez que a Educação Especial é voltada apenas para alunos com necessidades especiais. Já a Educação Inclusiva envolve colocar todos os alunos aprendendo juntos, tanto os com deficiência como os sem; para garantir a socialização. Aqui falamos sobre as duas vertentes: Educação Especial e Inclusiva, porque acreditamos que uma educação de qualidade não pode ser excludente. Dessa forma, os alunos com deficiência devem permanecer no ensino regular.

Destacamos, também, que é de suma importância não só que todos os alunos aprendam juntos, e para isso a escola precisa estar preparada para recebê-los, mas também que é fundamental que eles recebam o apoio da família. Porque é na família que se tem o primeiro contato social, é na família que a criança se sente segura e confortável. Dessa forma, havendo articulação entre escola e família será possível melhorar a forma de abordagem com o aluno.

Verificou-se que a comunicação entre escolas e pais deve ser contínua, mesmo que haja impossibilidade de os pais estarem sempre na escola, outros métodos devem ser utilizados, como: e-mails, sms, reuniões on-line, blogs e aplicativos da escola. Isso 
beneficiará tanto os pais que se sentirão seguros em deixar seus filhos na escola, quanto toda a equipe pedagógica que saberá como lidar com o aluno.

Versou-se, em seguida, sobre o preconceito na escola. Falou-se que isso acontece desde a idade medieval, sendo de diversos tipos; entre eles o preconceito contra pessoas com deficiência. Sendo a escola um ambiente onde existem diversos tipos de raças e culturas, também precisa haver conscientização contra qualquer tipo de preconceito, através de conteúdos e metodologias de ensino.

Enfim, o que se propôs aqui foi um trabalho voltado para o aluno com deficiência. Apresentou proposta para a escola, os professores, a família e toda a comunidade escolar. Tudo isso no intuito do melhor ensino-aprendizagem. 


\section{REFERÊNCIAS}

. Conselho Nacional de Educação. Parecer 17/2001, de 3 de julho de 2001.

Diretrizes Nacionais para a Educação Especial na Educação Básica. Brasília: CNE/CEB, 2001.

ARMON, Jennie; TERRY, Dalia. Collaboration with Parents in the Special Education Setting. SpED 602: Introduction to Teaching Students with Disabilities Professor Sharon Link

BARUAH, Trisha Dowerah. Effectiveness of Social Media as a tool of communication and its potential for technology enabled connections: A micro-level study. International Journal of Scientific and Research Publications, Volume 2, Issue 5, May 2012.

BOTTEGA, Fernanda; RAFFAELLI, A. F. O Educar Sensível e as Possibilidades no século XXI. Disponível em:http://faifaculdades.edu.br/eventos/SEMIC/2014/5SEMIC/arquivo s/resumos/RES3.pdf Acesso em: 10 abr. 2021.

BRASIL, Ministério da Educação. Parâmetros Curriculares Nacionais para o Ensino Fundamental. Brasília, MEC/SEF. Rio de Janeiro: Pioneira, 1997.

CAMPBELL, Selma Inês. Múltiplas Faces da Inclusão. Rio de Janeiro: Wak Editora, 2009.

CORBIS, Marius Becker. The Value of Inclusive Education. Open society foundations, may, 2019. Disponível em <https://www.opensocietyfoundations.org/explainers/value-inclusiveeducation> Acesso em 20/04/2021.

CORDEIRO, Aliciene Fusca Machado; BUENDGENS, Jully Fortunato. Preconceitos na Escola: Sentidos e Significados Atribuídos pelos Adolescentes. 2012. Disponível em: https://www.scielo.br/pdf/pee/v16n1/05.pdf Acesso em; 15 abr 2021.

DESSEN, Maria Auxiliadora; POLONIA, Ana da Costa. A família e a escola como contextos de desenvolvimento humano. Ribeirão Preto: Paidéia. Vol. 17. n. 36. Jan/Abr. DES. Disponível em: https://www.scielo.br/j/paideia/a/dQZLXXCsTNbWg8JNGRcV9pN/?lang=pt. Acesso em: 02 jun. 2021.

FERRANTE, Charmaine Agius. A CASE STUDY OF INCLUSION AND DIVERSITY: A WHOLE SCHOOL APPROACH USING THE SOCIAL MODEL OF DISABILITY. Research undertaken in the School of Health, Community and Education Studies, 2012.

FREITAS, Neli Klix. Educação inclusiva e cidadania: aproximações e contradições. Revista Eletrônica de Educação, v. 5, n. 1, p. 40-56, 2011.

GADOTTI, M. Educar para um outro mundo possível. 1. ed. São Paulo: Publisher Brasil, 2007.

GALLO, Sílvio. Transversalidade e educação: pensando uma educação não disciplinar. In: ALVES, Nilda; GARCIA, Regina Leite (orgs.). O sentindo da escola. 3. Ed. Rio de Janeiro: DP\&A, 2000.

GIARDINETTO, A. R. S. B. Educação do aluno com autismo: um estudo circunstanciado da experiência escolar inclusiva e as contribuições do currículo funcional natural. 2009, $194 \mathrm{f}$. Tese de doutorado (Doutorado em Educação) - Faculdade de Filosofia e Ciências, Universidade Estadual Paulista, Marília. 2009. 
GREY, Dan. Communications: The Dos and Don'ts of School Communication with Parents. Communication between schools and parents is crucial, and it's up to you to maintain a healthy and collaborative relationship. Disponível em <https://www.eduprise.co.uk/blog/thedos-and-donts-of-school-communication-with-parents> Acesso em 20/04/2021.

GUTIERRES, A. F. A Sensibilização e a Formação de Professores para o Trabalho de Alunos Incluídos.EDUCERE, 2015. Disponível em:

https://educere.bruc.com.br/arquivo/pdf2015/21843_11224.pdf Acesso em: 12 abr. 2021.

LUCENA, Maria da Conceição. A importância da afetividade na educação inclusiva. Portal Educação, 2020. Disponível em:<https://siteantigo.portaleducacao.com.br/conteudo/artigos/e ducacao/a-importancia-da-afetividade-na-educacao-inclusiva/33608\#> Acesso em: 02 jun. 2021.

MARTINS, Vicente. A Educação em Valores. 2005. Disponível em: https://www.construirnoticias.com.br/a-educacao-em-valores-na-lei-de-diretrizes-e-basesprofessor-vicente-martins/ Acesso em 18 abr 2021.

MATURANA, H. Emoções e Linguagem na Educação e na Política. Belo Horizonte: editora UFMG, 1998.

MCGOEY, K. Tips for Parents: Collaborating with School Personnel - Strategies for Successful Partnering. Davidson Institute for Talent Development Online, 2008.

MICHAELIS, H. Moderno dicionário da língua portuguesa. São Paulo/SP: Companhia Melhoramentos, 1998.

PAULA, A. R.; COSTA, C. M. A hora e a vez da família em uma sociedade inclusiva. Brasília: MEC, 2007.

SAMPAIO, Noelia. Desconstruindo o Preconceito na Sociedade Contemporânea. 2015. Disponível em: http://www.editorajc.com.br/desconstruindo-o-preconceito-na-sociedadecontemporanea/ Acesso em: 15 abr. 2021.

SASSAKI, Romeu Kasumi. Inclusão: Construindo uma Sociedade para Todos. $5^{\circ}$ ed. São Paulo: Editora Áurea, 2003.

SILVA, Adilson Florentino da. A inclusão escolar de alunos com necessidades educacionais especiais DEFICIÊNCIA FÍSICA. Ministério da Educação Secretaria de Educação Especial, 2006.

SILVA, Ana Paula Mesquita Da; ARRUDA, Aparecida Luvizotto Medina Martins. O Papel do Professor Diante da Inclusão Escolar. Revista Eletrônica Saberes da Educação - Volume $5-\mathrm{n}^{\circ} 1-2014$

Silva, D. J. (2005). Educação, preconceito e formação de professores. Em R. M. C. Libório \& Silva, D. J. (Orgs.), Valores, Preconceitos e Práticas Educativas (pp. 125-141). São Paulo: Casa do Psicólogo.

SOUZA, Fabiana Veríssimo da Costa; CUNHA, Valeska Guimarães Rezende. A educação inclusiva na perspectiva dos professores da rede municipal de Frutal: um estudo de representações sociais. Cadernos da Fucamp, v.18, n.32, 2019. 
SOUZA, R. R.; OLIVEIRA, I. A. Representações sociais e formação de professores: no contexto de um paradigma de reconhecimento do outro. In: SEMINÁRIO NACIONAL DE PESQUISA EM EDUCAÇÃO ESPECIAL, 5.,2009, São Paulo. Formação de professores em foco. São Paulo, SP: Universidade Estadual do Pará, 2009.

SYRIOPOULOU-DELLI CK, CASSIMOS DC, POLYCHRONOPOULOU SA. Collaboration between teachers and parents of children with ASD on issues of education. Res Dev Disabil. 2016.

VILARINHO, Sabrina. Preconceito um fato que deve ser trabalhado desde os primeiros anos. 2021. Disponível em: https://educador.brasilescola.uol.com.br/estrategiasensino/preconceitoum-fato-quedeve-ser-trabalhado-desde-os-.htm Acesso em: 18 abr. 2021. 


\section{CAPÍTULO 12}

\section{A IMPORTÂNCIA DA AFETIVIDADE NA INCLUSÃO ESCOLAR}

Fernando Icaro Jorge Cunha

Universidade Federal do Pampa - Unipampa

Perfil: http://lattes.cnpq.br/1495581852115

E-mail: icaro729@gmail.com

\section{Eleonora Leguiçamo Centena Silva}

Universidade da Região da Campanha - URCAMP

Perfil: http://lattes.cnpq.br/4873255525491550

E-mail: eleonora.centena@hotmail.com

\section{Janine Viven Nunes Quevedo}

Pontifícia Universidade Católica do Rio Grande do Sul - PUCRS

E-mail: j.jquevedo@hotmail.com

\section{Suélen De Prá Alves}

Pontifícia Universidade Católica do Rio Grande do Sul - PUCRS

E-mail: deprasuelem@gmail.com

\section{Karen Krystine Oldani Da Silva}

Pontifícia Universidade Católica do Rio Grande do Sul - PUCRS

Perfil: http://lattes.cnpq.br/5172731026216298

E-mail: karen_oldani@hotmail.com

\section{Maria José Baltar De Azambuja}

Escola Municipal Especial de ensino Fundamental Lygia Morrone Averbuck

Perfil: http://lattes.cnpq.br/8379431150091984

E-mail:mj.azambuja@bol.com.br

\section{Janete Mendonça Chrispim Maia}

Universidade Iguaçu - UNIG

Perfil: http://lattes.cnpq.br/7657514122345716

E-mail: Jmenconca.prof@gmail.com

\section{Salete Pereira Zanella}

Universidade Federal de Pelotas - UFpel

Perfil: http://lattes.cnpq.br/9831463605016855

E-mail: soldreher@gmail.com

\section{Janete Hickmann}

Rede de Ensino Municipal de São Leopoldo - RS

Perfil: http://lattes.cnpq.br/0461298984464544

E-mail: janete22h@gmail.com 


\section{Liliana Vieira Martins}

Centro de Produção da UERJ - CEPUERJ

Perfil: http://lattes.cnpq.br/3660548886422327

E-mail: lilith.vieira@gmail.com

Resumo: No Brasil a educação inclusiva está definida em legislação, apesar disso sabemos que no contexto atual os serviços pedagógicos existentes ainda estão longe de viabilizar a Educação Inclusiva. Escolas e professores buscam agir de maneira efetiva na aprendizagem de crianças com deficiência, mas acabam sendo limitados diante à falta de incentivo de políticas públicas que orientem uma prática inclusiva no ambiente escolar. Diante desse tema de extrema relevância, o presente trabalho bibliográfico de caráter descritivo se constitui qualitativo tem como objetivo verificar a importância da afetividade na inclusão escolar. As inquietações e diversos desafios fazem parte do processo, no entanto, temos que buscar maneiras de minimizar as consequências da falta de apoio e despreparo. Sabe-se que a afetividade é muito importante no processo ensino-aprendizagem e o bom relacionamento professoraluno promove uma aprendizagem satisfatória.

Palavras-chave: Escola; Educação inclusiva; Afetividade; Aprendizagem. 


\section{INTRODUÇÃO}

A inclusão de crianças e jovens com necessidades especiais nas escolas brasileiras ainda é pouco discutida, embora sendo um tema de enorme relevância o que se percebe é que as instituições escolares ainda não estão preparadas para promover o desenvolvimento educacional desses educandos no nível desejado.

A Inclusão escolar parte da ideia que todas as pessoas sem distinção de gênero, etnia, religião, classe social, condições físicas e psicológicas, etc. devem ter acesso à educação de modo igual, sendo que seu principal objetivo nos dias atuais é a inclusão de crianças e jovens portadores de necessidades educacionais especiais (NEE), que apresentam algum tipo de deficiência física ou psicológica. Esse direito é garantido pelo artigo 208 da Constituição Federal de 1988 que diz que é dever do estado garantir o atendimento educacional especializado aos portadores de deficiência, preferencialmente na rede regular de ensino, esse direito também é reforçado pelo Estatuto da Criança e do Adolescente (ECA).

As leis garantem o acesso das crianças e jovens portadores de necessidades especiais em escolas de ensino regular, porém essa garantia de educação inclusiva não deve representar apenas o direito à matrícula, mas uma participação efetiva em todos os contextos escolares, viabilizando meios para que os profissionais envolvidos exerçam suas funções satisfatoriamente com alternativas, recursos, materiais e condições necessárias que garantam este direito.

Cientes de que a cada ano que passa mais crianças e jovens com necessidades são inseridas na rede regular de ensino, por isso, cada vez mais são necessárias mudanças de atitude não só por parte dos educadores, mas também de toda comunidade escolar envolvida neste contexto.

A afetividade no ambiente escolar favorece o ensino aprendizagem, uma vez que os educadores comprometidos com a educação não apenas transmitem conhecimento, mas sim viabilizam meios para que a aprendizagem se efetive seja através da escuta, do afeto, de uma relação de troca etc. Segundo Freire,1996 ensinar não é transferir conhecimento, mas criar possibilidades para a sua produção ou sua construção.

Diretamente ligada à emoção, a afetividade consegue determinar o modo com que as pessoas visualizam o mundo e também a forma com que se manifesta dentro 
dele, está presente em todos os campos da vida e se manifesta através dos sentimentos, desejos, interesses, tendências, valores e emoções, ou seja é um estado psicológico de todo ser humano. Dessa forma, a presença ou ausência do afeto determina a forma com que o indivíduo se desenvolverá. Também favorece a autoestima desde a infância, a criança que recebe afeto dos outros consegue se desenvolver com segurança e determinação.

O ser humano constituído subjetivamente depende integralmente dos outros seres humanos, as relações interpessoais estabelecidas contribuem para o desenvolvimento do sujeito diminuindo as dificuldades que são impostas frente os obstáculos diários do cotidiano escolar. Estas relações devem se fazer presente no ambiente escolar envolvendo toda a comunidade a fim de prover o desenvolvimento pleno do educando.

\subsection{O Papel da Escola na Educação Inclusiva}

O século XXI abrange condições desafiadoras à sociedade atual. As notícias informadas pelos vários meios de comunicação, muitas vezes em tempo real, trazem angústia às pessoas. Dentre esses diversos assuntos que permeiam a população, encontram-se os desafios enfrentados pela educação.

Todo ser humano tem direito à educação. Direitos que são universais, indivisíveis e interdependentes. E quando estes direitos são assegurados, estamos colocando em prática todo um conjunto de direitos humanos.

Possuímos aspectos diferenciados em todas suas formas, quer seja de opiniões, físicas, de gênero ou étnicos e, estes aspectos estão numa pauta que devem e precisam ser envolvidos e desenvolvidos na e pela escola.

A temática da diversidade, e, no nosso caso, das pessoas com deficiência, tem sido verificada de perto na atualidade com o objetivo de levar à educação para todos indistintamente.

Várias leis têm sido criadas com a vontade de não violar direitos fundamentais de todos os seres humanos. A declaração de Salamanca (1994), enfatiza que toda criança tem a educação como direito fundamental, devendo ser dada a oportunidade de aprender. Em nossa constituição de 1988 é versado que a educação é direito de todos e dever do Estado e da família, visando o preparo de pessoas para o serviço da 
cidadania e para o trabalho. Na Lei de Diretrizes e Bases da Educação Nacional (LDB) - Lei 9394/1996, declara que a educação especial será oferecida preferencialmente na rede regular de ensino. E por último a lei 13.146/2015, regulamentada com Lei Brasileira de Inclusão, expõe que toda pessoa com deficiência terá direito à igualdade de oportunidade e não sofrerá nenhuma espécie de discriminação. Portanto, são diversas leis que deixam claro a necessidade de se unir esse todo de diversidades para caminharmos no sentido da igualdade no direito à educação de todo o ser humano. Contudo, na prática, dependendo do contexto social e das informações que chegam de forma desvinculada, não podemos caracterizar que isso aconteça. A educação hoje, em muitas das escolas, que obtém o ensino inclusivo, deixou esse ato de inclusão um ato gélido em que o aluno passa a ser o receptor do conteúdo a ser ensinado e, muitas vezes, não assimila da forma correta o que poderia aprender.

Os limites de uma educação não se baseiam apenas em atribuir conhecimentos a um indivíduo, é necessário ajudar este educando a relacionar-se com o mundo e sociedade de forma absoluta, autêntica e que corresponda a suas expectativas, quer seja, durante ou futuramente depois da escola. Na visão de Alves e Garcia (2001), para que a educação seja efetiva é necessária uma postura para além do discurso, ou seja, é necessária a prática, a vivência, em sala de aula e fora dela.

É preciso modificar aspectos já utilizados que se relacionam a formas tradicionais de educação. Discursar frente a uma classe, acreditando que todos os alunos assimilem da mesma forma é caracterizar um ensino retrogrado e em defasagem. O procedimento correto deve ser pautado como micro social em direção ao todo, onde levamos a ser humano a atingir o propósito com posturas de liberdade, respeito, responsabilidade, ao mesmo tempo que vai percebendo que todos os membros da sociedade reagem de forma parecida, na prática, decorrente das diferentes formas de aprendizagem.

Para Alarcão (2011), que também participa desta ideia, a escola é um setor da sociedade, e esses dois se entrelaçam em influência. Para se obter educação é preciso que aconteça a formação de cidadãos críticos, que desenvolvem as aptidões da compreensão. Essas aptidões expandem as capacidades de escutar, observar, pensar, entender não somente ao redor do mundo em que se viva, mas também ampliando-se para que se tenha um ponto de vista dos acontecimentos de forma 
generalizada, de tal forma que os educandos sejam capazes de interagir, desenvolvendo autoconhecimento e autoestima.

Portanto, formar um aluno em sua integridade, não é apenas instruí-lo, através de transmissão de conteúdo, mas também formá-lo para um convívio em sociedade.

A escola é o local que se destina ao ensino de discentes, sempre com o intuito de formar e desenvolver cada indivíduo nos seus diversos aspectos: cultural, social e cognitivo.

A escola contemporânea possui o papel de organizar seu currículo e métodos para educar, sempre englobando a singularidade de cada educando, fomentando a inclusão daqueles que diante da história das sociedades estavam excluídos, pelo pensamento de que não poderiam adequar-se a convivência dita normal. Contudo, bastava apenas dar-Ihes oportunidades e meios de acesso em um mundo que não foi organizado para as deficiências.

Atualmente já nos é exposto um modelo escolar que pode ser seguido como padrão, fazendo-se necessário aprendermos a conviver com as diferenças e com a aprendizagem pela afetividade significativa.

Segundo Maria Teresa Mantoan é preciso repensar a escola de qualidade, superando o sistema tradicional de ensinar, é preciso refletir no que se ensina e como se ensina, para formar pessoas éticos e humanas, que valorizam a diferença na convivência com seus pares, gerando um clima sócio afetivo, sem tensões e competições, mas com espírito solidário e participativo.

Antes de conhecer o modelo de Educação Inclusiva que hoje nos é garantido por lei nas escolas de todo país, é importante sabermos que o mesmo se derivou de uma longa trajetória historicamente produzida. Em outras palavras, o modelo de Educação Inclusiva é fruto de mudanças históricas que foram constituídas socialmente, já que, até o final da década de 1980, as pessoas com deficiência não tinham o direito de frequentar escolas regulares.

No ensino brasileiro, a educação inclusiva foi implementada no ano de 2003, pelo MEC (Ministério da Educação e Cultura), pois antes disso, o sistema educativo brasileiro era segmentado em duas vertentes: escola especial (para alunos com qualquer tipo de deficiência ou transtorno, com altas habilidade) e escola regular ( para alunos sem nenhum tipo de deficiência ou transtorno). 
É dever da escola atualmente aceitar os alunos com capacidades diferenciadas e realizar as adaptações necessárias para que tenham seu direito de educação garantido. Pois através dessa contextualização talvez se consiga esclarecer uma das principais barreiras que gira em torno desse assunto, tão importante, que é a exclusão, quando relacionada a diferenças.

Desta forma, tanto o processo educativo escolar quanto o desenvolver de estruturas físicas, recoloca a cada instante a reformulação do velho e a possibilidade de construção do novo e, nenhum dos lados pode deixar claro sua vitória completa e definitiva em comparação ao outro, porque ambas parecem estar presentes no cenário da educação brasileira, neste momento.

A modificação de uma escola para que se torne inclusiva é um processo que requer muito mais do que transferir crianças da escola especial para a escola regular ou garantir acesso à todos à escola regular. Propiciar a inclusão é fazer parte da reorganização do âmbito escolar, participar do processo de mudança, tendo o direito de aprender junto, independente das condições físicas, linguísticas, intelectuais sociais e emocionais.

A escola tem que ser o reflexo da vida do lado de fora. O grande ganho, para todos, é viver experiências da diferença. Se os estudantes não passarem por isso na infância, mais tarde terão muitas dificuldades de vencer preconceitos. A Inclusão possibilita aos que são discriminados pela deficiência, ocupem por direito o seu espaço na sociedade. Se isso não ocorrer, essas pessoas serão sempre dependentes e terão uma vida cidadã pela metade.

Uma escola inclusiva tem por unanimidade acolher a todos, respeitando o ritmo de cada aluno e fornecendo estrutura necessária para seu aprendizado. Bem como, desenvolver suas atividades, com regulamentação coerente com seu projeto pedagógico, fornecendo capacitação e formação continuada para seus educadores para que possam realizar um trabalho coerente e de qualidade, além dos professores especializados que a escola tem o dever de comportar.

Para Mantoan (2015), essa resistência da escola tradicional relacionada à inclusão e a mesma, demonstra a sua inaptidão de atuar diante da complexidade, das multiplicidades e do ser único.

É necessário uma estrutura de escola que comportem o acesso das pessoas tanto no aspecto social, educacional como no afetivo. Segundo Mattos (2008, p. 52), 
"incluir significa fazer algo para que elas permaneçam na escola". Incluir requer considerar peculiaridades, requer cruzamento de culturas, requer olhar a singularidade de cada um dentro da pluralidade, requer olhar a parte no todo e o todo na parte. Implica, ainda, considerar as crenças, mitos e valores de cada um, bem como considerar as emoções envolvidas no relacionamento.

Admitir um novo valor à escola nos aspectos de estrutura física, adaptações curriculares e mudança atitudinais dos educadores e se permitir a ajudar os alunos a transpor seus limites também é um ato de inclusão, isso faz com que o aluno entenda o significado de permanecer na escola e ressignifica o verdadeiro papel da escola diante da aprendizagem, gerando um ambiente escolar saudável e estimulador.

Devemos considerar que estruturas de cunho afetivo bem como cognitivos cabe ao lado humano da gestão e dos educadores sanarem à medida que as situações vão se apresentando, entretanto, mudanças relacionadas às estruturas físicas são um pouco mais complexas.

Em nosso país muitas das escolas públicas, que possuem um poder aquisitivo bem inferior às escolas privadas, não possuem recursos necessários para fazer adaptações ou comprar equipamentos necessários à necessidade de seus alunos com deficiências.

A estrutura física nem sempre é a mais adequada. Ocorre a falta de recursos de tecnologia assistiva, há uma capacidade exagerada de número de alunos por turmas, que desqualifica qualquer tipo de ensino, não somente para alunos com deficiência, mas também para todas as diversidades que o ser humano traz consigo.

A Base Nacional Comum Curricular (BNCC) é um documento norteador das escolas. Este documento deve ser seguido por toda a educação básica, não se tratando de algo fixo e imutável. Respeitando essa análise e tornando efetivo o aspecto pedagógico escolar, para uma escola ser inclusiva, em primeiro lugar devemos priorizar um bom projeto político pedagógico, também denominado como proposta pedagógica, resultou de muitas mudanças que aconteceram historicamente na educação brasileira, motivadas pela busca de melhorias na qualidade de ensino. Este deve valorizar a cultura, a história e as experiências anteriores. As práticas também precisam ser revistas, utilizando-se sempre de uma metodologia ativa.

Currículos, métodos, técnicas, recursos e organizações devem estar previsto no Projeto Político Pedagógico que, segundo o documento do Ministério público 
denominado "O Acesso de alunos com deficiência às escolas e classes comuns na rede regular":

[...] Implica em um estudo e um planejamento de trabalho envolvendo todos os que compõem a comunidade escolar, com o objetivo de estabelecer prioridade de atuação, objetivos, metas e responsabilidades que vão definir o plano de ação das escolas, de acordo com o perfil de cada uma: as especificidades do alunado, da equipe de professores, funcionários e, num dado espaço de tempo, o ano letivo (BRASIL, 2004, p.33).

No papel da escola frente ao formato de uma educação inclusiva, é necessário, além de focar a atenção nos professores e alunos, repensar o papel da gestão escolar, que abrange sobretudo, a orientação, a coordenação e a direção educacional. Isso significa que toda a escola precisa se engajar no processo de reconstrução da filosofia da escola inclusiva prevista na proposta pedagógica. A gestão escolar necessita atentar para assumir como ponto de partida, as práticas e conhecimentos existentes, ver as diferenças com oportunidades, usar recursos disponíveis para apoio à aprendizagem e criar condições incentivadoras e riscos, precisando assim conhecer profundamente as políticas de inclusão, para que os direitos da escola sejam garantidos e os deveres cumpridos.

Outros aspectos inerentes a essas mudanças seriam as redes de apoio. Situações importantes que podem acontecer de diversas maneiras destinadas a discutir assuntos importantes relacionados a uma escola inclusiva.

[...] É um grupo de pessoas que se reúnem, para debater, resolver problemas, trocas de ideias, métodos, técnicas e atividades para ajudar os professores e/ou alunos a conseguirem o apoio de que necessitam para serem bemsucedidos em seus papeis. ( SCHAFFNER; BUSWELL, 1999, p 74).

Umas das formas bem-sucedidas de redes de apoio são os cursos e palestras, disponibilizados aos professores e a comunidade escolar como forma de sanar dúvidas e trazer novas situações a serem implementadas no dia a dia escolar.

A participação efetiva da comunidade escolar, ou seja, de pessoas que estão ligadas direta ou indiretamente com a escola, traz um apoio importante à escola. Descaracterizando aqui o papel somente dos pais que comparecem mediante chamamento escolar. Todas essas formas indicam que a maneira mais eficaz para a contribuição à uma escola inclusiva é a experiência adquirida com o próprio filho mediante a situação.

É preciso levar em consideração, portanto, todas as situações colocadas anteriormente para a compreensão de uma escola inclusiva, sendo este o local que 
existe, de mais específico, de convivência das diversidades humanas. Dentre essas diversidades torna-se muito claro o papel da formação de um cidadão e um caminho afetuoso, para termos a direção e motivação para a inclusão de qualquer educando no ambiente escolar.

\section{RELAÇÃO PROFESSOR-ALUNO}

A relação entre o professor e o aluno em sala de aula tem relevância significativa e favorece o processo ensino aprendizagem, o afeto atua de modo significativo neste processo.

Segundo Piaget (1992), o desenvolvimento intelectual possui dois componentes que são: o cognitivo e o afetivo. Esses dois são paralelos e o cuidado com o componente afetivo é extremamente importante. Em todas as fases da vida a criança tem potencialidades, as portadoras de necessidades especiais também, dessa forma conclui-se que mesmo com suas diferenças nas áreas biológicas, culturais, físicas, cognitivas e psíquicas, quando a aula é planejada, contextualizada e adequada a sua realidade, a motivação para aprender se fará presente. Os professores que desenvolvem relação de afeto com seus alunos percebem 0 envolvimento emocional e o interesse pelas atividades diárias, as mudanças de comportamento são de extrema relevância. Um ambiente saudável favorece o desenvolvimento da autonomia cognitiva e afetiva, autorregulação e cooperação, esta reciprocidade de sentimentos cria um ambiente propício para aprendizagens significativas.

Segundo Ribeiro e Jutras (2006), a afetividade contribui para a criação de um clima de compreensão, de confiança, de respeito mútuo, de motivação de amor, que pode trazer benefícios para aprendizagem escolar.

Na parte inicial dos PCNs (1997) lê-se que: "os aspectos emocionais e afetivos são tão importantes quanto os cognitivos, principalmente para os alunos prejudicados por fracassos escolares ou que não estejam interessados no que a escola pode oferecer". Para que a aprendizagem se efetive o educando tem que estar envolvido pela vontade de aprender caso contrário a afetividade não contribuirá para que a aprendizagem se efetive. Cabe aos professores estarem antenados contextualizando o ensino e oferecendo uma aprendizagem significativa. Nos PCNs (1997) também 
consta a declaração de que devemos potencializar a disponibilidade do educando para aprendizagem significativa já que o mesmo "precisa tomar para si a necessidade e a vontade de aprender".

Educadores e demais profissionais da educação ainda enfrentam desafios com a educação inclusiva, pois necessitam repensar sua prática pedagógica diariamente diante de cada aluno e suas singularidades a fim de verificar as potencialidades e desenvolver as habilidades de cada um.

\begin{abstract}
A inclusão implica que todos os professores têm o direito de esperar receber preparação apropriada na formação inicial em educação e desenvolvimento profissional contínuo durante sua vida profissional (MITTLER,2003).
\end{abstract}

Não somente os profissionais da educação, mas também as escolas necessitam se reestrutura, se atualizando e se adequando para que possam atender satisfatoriamente os alunos com necessidades educacionais especiais, pois como já havíamos comentado esses educandos não podem ser vistos somente como uma matrícula, a educação inclusiva ressalta em seu princípio básico que:

\footnotetext{
Todas as crianças deveriam aprender juntas independente de quaisquer dificuldades ou diferenças que possam ter. As escolas inclusivas devem reconhecer e responder às necessidades de seus alunos, acomodando tanto estilos como ritmos diferentes de aprendizagem e assegurando uma educação de qualidade a todos, por meio de currículo apropriado, modificações organizacionais, estratégias de ensino, usar de recursos e parecerias com a comunidade (BRASIL,1994).
}

O desenvolvimento das habilidades intelectuais e sociais do aluno, é o papel do professor na educação inclusiva, elaborar um plano de aula que contemple toda a turma, sem distinção e sem dúvida é imprescindível. Além disso, é relevante que o educador estimule o aluno e comemore as suas pequenas conquistas sempre.

\title{
3. AFETIVIDADE E A INCLUSÃO ESCOLAR
}

Quando relacionamos toda e qualquer situação acerca de um assunto, é preciso ponderar todas as questões que fazem parte dele, mesmo que não sejam aprofundadas, mas que nos esclareçam as vertentes que precisam ser analisadas. Na importância da afetividade para uma aprendizagem significativa, não podemos nos reportar apenas a um ambiente de convívio, o escolar, e sim aos vários locais em que a diversidade está presente. Para tanto, é inerente refletir sobre o ser humano como ser primeiro desse processo de afetividade, o qual vem desde seu nascimento e como 
ela se expressa ao longo da vida do indivíduo, tornando-se prioritária na aprendizagem e na formação do indivíduo. O papel importantíssimo da família como agente atuante. O papel da escola na construção de um meio adequado à educação de qualidade afetiva e prazerosa, não deixando de analisar o quanto esta afetividade ajuda a minimizar essa estrutura complexa de ensino-aprendizagem.

Refletir sobre a relevância da afetividade para a aprendizagem é necessário, com enfoque no sujeito e sua integração com os outros e com o ambiente em que vive, para entender quais situações se tornam positivas ou negativas sobre sua aprendizagem global.

Atualmente, fala-se muito sobre as causas e consequências da indisciplina, do pouco aproveitamento que conduz à evasão de educandos, de todas as classes, localidades, de tipos de escola, quase sempre numa narrativa que traz a figura do aluno e da família, minimizando o papel do professor, da escola e de outros elementos, também responsáveis por esses impasses.

Se você prestar atenção em você mesmo e depois observar as pessoas que passam pela sua vida, é certo que encontrará mais diferenças do que semelhanças. Desse modo, é importante que haja respeito para que seja possível aprender e crescer com essas diferenças, em vez de transformá-las em motivos para desentendimentos.

Os dilemas em relação à inclusão e, mais particularmente, à afetividade para que essa, de fato seja, consolidada, poderão ser eliminados ou, reduzidos por meio de gestos de sensibilização social e, em seguida, mediante a convivência na diversidade humana dentro das escolas inclusivas.

Cabem reflexões como estas, que dirijam um olhar para um determinado ponto trazendo orientação e apoio aos envolvidos no processo ensino-aprendizagem, enriquecendo esta atividade tão indispensável ao desenvolvimento pessoal e social dos indivíduos.

A cognição e a afetividade contêm bases orgânicas que vão obtendo complexidade em contato com o social. "O nascimento da afetividade é anterior à inteligência". Contudo, a "inteligência não se desenvolve sem afetividade e vice-versa, pois ambas compõem uma unidade de contrários" (WALLON apud ALMEIDA, 2012, p. 29 e 42). 
Quando tentamos entender o significado de afetividade, a palavra, por si só, já nos dá uma ideia de derivação de afeto relacionado à carinho, à afeição e ao amor que se tem por certas pessoas, objetos ou situações.

A afetividade relaciona-se a competência do ser humano de ser atingido positiva ou negativamente por sensações internas ou externas. O sentimento quando positivo traz o bem-estar para que o indivíduo se sinta parte de um todo, desenvolva o seu caráter e a sua autoconfiança. A falta da afetividade pode trazer vários transtornos para uma pessoa, caracterizando na sociedade pessoas que se mostram tão distantes quando o assunto são os sentimentos e emoções, já que, possivelmente, não lhes foi oportuno conhecer essas sensações na infância, utilizando essa situação como meio de se protegerem.

Crianças que crescem em um ambiente amoroso têm mais chances de se tornarem adultos igualmente afetivos e seguros, o que irá impactar em toda a vida.

Segundo o pensamento do escritor e filósofo Henri Wallon, a Afetividade está presente em maior ou menor grau, em todos os momentos de nossas vidas, sendo necessária a interação a esse processo, para a formação desse indivíduo como ser social, cultural e inserido no meio em que vive.

Trazendo informações que as maneiras de viver das pessoas são divididas em de três etapas: motora, afetiva e psíquica, que agem de forma conjunta e, mesmo que em determinado momento quando uma etapa pareça dominar, essa dominância sofre uma troca e as conquistas ocorridas em uma são incorporadas às outras.

Wallon, em seus estudos, ressalta que a Afetividade se destaca de três maneiras: a primeira é relativa à emoção, onde há exteriorização da afetividade, aparece desde o início da vida do ser humano e é caracterizada com movimentos de espasmos e contrações, liberando sensações de bem ou mal-estar. A segunda é relativa ao sentimento: expressando a afetividade com controle, pela mímica e também pela linguagem, o que o diferencia da emoção, com caráter cognitivo. No terceiro e último momento está presente a paixão, é a partir daí que relata-se a fase do personalismo e se caracteriza pelo autocontrole no domínio de uma situação, exteriorizando-se através de ciúmes e exigência de exclusividade, entre outros.

Para Vygotsky, "a história da sociedade e o desenvolvimento humano caminham juntos", sendo o conhecimento internalizado e transformado pela criança através da sua interação ou trocas sociais com as pessoas que a rodeiam. (LAKOMY, 
2003 p.38). Por conseguinte, fica clara a importância da família, e também da escola como instituição formadora, para o desenvolvimento global desse ser.

Como a família é a base e o primeiro núcleo de interação da criança, este media o processo de aprendizagem. Contudo, tem-se a noção, que a família nos dias de hoje é uma instituição em crise, onde muitas vezes a afetividade designada a filho é substituída por obrigações financeiras e materiais e isso tem prejudicado a vida de crianças e jovens. Explicar o "sim" e o "não", dentre tantas outras situações, geram atitudes que fazem toda uma diferença e são essas atitudes de amor, carinho e escuta atenciosa, que fazem ela aprender a ver o mundo de forma mais positiva facilitando a convivência em sociedade. É importante frisar que colocar limites, cobrar acordos feitos, recriminar o que não está certo, também são formas de demonstrar afeto e ajudam na formação do sujeito responsável, ético, solidário.

A capacidade do ser humano de ser afetado positivamente é que consegue interceder entre aprendizagem e os relacionamentos desenvolvidos em sala de aula. Prioriza-se então, a permanência deste aluno na escola com aceitação, motivação e autoconfiança e que isso seja refletido no educando quando entrar no ambiente escolar. Esses agentes e tantos outros devem facilitar a permanência e aprendizagem.

A escola precisa criar mecanismos necessários para a aprendizagem do aluno. Este ao sentir que possui sua atenção atendida, sente segurança evoluindo sua autoestima. Mas é muito importante que essa união de situações articule tanto o aspecto cognitivo quanto o aspecto afetivo, pois mesmo, estes sendo opostos, dependem um do outro para o desenvolvimento da criança com necessidades especiais. Portanto, para que o intelecto desenvolva-se é importante administrar determinados sentimentos que envolvem o processo contínuo e recíproco de aprendizagem.

Quando o ambiente é saudável, há um grande desenvolvimento das relações afetivas para o aluno com deficiência. O professor que torna essa prática consistente em sala de aula consegue analisar a superação de barreiras e bloqueios que impedem muitas vezes do educando aprender.

É necessário que toda equipe que faz parte do âmbito escolar, esteja trabalhando em conjunto perante as diversidades existentes e atuem saudavelmente e de acordo com o entendimento do educando. Esse ato de incluir modifica toda uma 
estrutura do papel de escola e qualifica a importância do afeto, caracterizando um ambiente com muita produtividade.

O processo de ensino-aprendizagens não tem dissociação e interage entre si. Promovendo a troca, intermediado, e levado a cabo pela via da afetividade e a compreensão das suas implicações no processo. Um dos elementos importantes para esse contexto, na atualidade, é o uso maciço da informática pelos educandos, o que pode ser positivo se o professor seguir as mudanças e utiliza as novas ferramentas que estão disponibilizadas na sociedade e também na escola, entretanto, pode ser negativo se a rota ver completamente inversa.

Frente às situações de inclusão e exclusão, que ainda acontecem muito na escola. É necessário que o educador fique atento a situações com desvalorizações de pessoas e impeça que essas colocações se tornem impetradas. A afetividade, portanto, é uma das propostas integrantes de formação e de humanização da escola como meio de inclusão.

Ao chegar à Escola, a criança já traz muitas vivências e experiências que não podem ser deixadas de lado pelo professor e demais agentes da instituição.

O professor que também faz parte dessas modificações, contudo por ser um adulto, tem maiores possibilidades de agir de forma equilibrada, para um bom desfecho dos conflitos que se apresentarem, entendendo isso ocasionará a qualidade da relação e da aprendizagem.

Há de perceber que o sucesso ou fracasso no processo, também pode partir de uma dificuldade de ensino, que pode recair na dificuldade de aprendizagem. Com a desvalorização do trabalho docente, do professor como profissional, da escola, a educação encontra-se em crise em seus objetivos e por fim as necessidades dos alunos, como a afetividade são deixadas de lado.

Fica claro que a pobreza afetiva prejudica o sujeito, principalmente o jovem que, até por conta da impulsividade própria da idade, tende a arriscar-se de forma temerária já que lhe faltam boas e construtivas referências. É urgente, portanto, a conscientização por parte da escola, da importância, sua como formadora e das suas metodologias, da forma de trabalhar e da sua postura, sua visão de aluno, para a formação do sujeito completo, com o atendimento das suas exigências cognitivas e afetivas, para que possa formar cidadãos, pois serão estes, que construirão uma sociedade igualitária, justa e solidária. 
A autoridade e postura de um educador corrobora com acordos e ajustes porque fazem com que o aluno perceba que o educador media e auxilia, mas não o faz com opressão. Os alunos sentem isso e respondem positivamente a esta dinâmica. O educador atua desta forma estimula a criatividade, o poder de expressão, de demonstração de sentimentos.

Quando requeremos um trabalho com qualidade devemos deixar de lado a ideia de que ele seja difícil, um educador consciente procura a melhor maneira de levar o conhecimento ao seu aluno, tornando mais que professor, mas também, um amigo, conselheiro e motivador.

O papel da afetividade não deve estar em segundo plano, mas sim ocupar o centro das atenções junto a conteúdos e métodos que fazem parte do currículo escolar, contribuindo sempre para o estímulo do ser humano. Sendo necessário inserir definitivamente a afetividade como elemento primordial, no processo, como um todo.

\section{CONSIDERAÇÕES FINAIS}

Entendemos que a educação como meio de desenvolvimento e formação de um cidadão obtém fortes bases pautadas em suas leis, que compõem os direitos sociais, econômicos e culturais. A educação, no conceito, como o da inclusão na Declaração de Salamanca, por exemplo, traz a importância que a inclusão escolar não seja somente restrita a pessoas com deficiências, mas a todo o ser humano, para sua formação global.

Esclarecemos que a diversidade é o cerne da questão que torna os seres humanos especiais, não somos diferentes porque possuímos necessidades, somos diferentes porque somos únicos. Destacamos a família como primeiro lugar onde a afetividade deve ser desenvolvida e, a escola é o local onde essas diferenças se tornam claras e precisam ser respeitadas para um futuro em sociedade.

A escola como local de acesso a todos, para aprendizagem em nível cognitivo e afetivo, necessita avaliar como se dá o processo de inclusão periodicamente. Apesar dos contextos tradicionais enraizados é possível a ressignificação de tais estruturas. Escapando da fixação de hábitos exclusivos, há o favorecimento de um ambiente mais produtivo e acolhedor. $\mathrm{O}$ acolhimento por parte de todos os envolvidos na escola, o engajamento na verdadeira inclusão, alimenta a afetividade, segurança e autoestima. 
Entender as diferentes formas de aprender e se comunicar, além de melhorar as potencialidades dos educandos com necessidades especiais, fomenta um ambiente produtivo e fornece uma aprendizagem significativa.

Umas das relações que é incluída como de grande relevância neste processo, é a relação professor e aluno, pois é através desta relação que a criança ou jovem conseguirá desenvolver com melhor qualidade e significância seu aprendizado. O professor, mesmo com todas as dificuldades que vem enfrentando perante à educação, necessita do entendimento que a criança com necessidades especiais, através de uma ação de valorização consegue melhor sua estadia e aprendizagem escolar, tornando o ambiente de sala de aula saudável.

A afetividade como mediadora na aprendizagem e nos relacionamentos desenvolvidos em âmbito escolar e sala de aula, é ponto crucial para que entendamos as diferenças de cada um, e sua realidade social e cultural. Partilhamos ainda que a permanência desses alunos na escola depende da aceitação, da motivação, autoconfiança que ele verifica.

Analisando desta forma, buscamos na afetividade um dos caminhos para aqueles discentes que foram excluídos pelo processo educativo, por uma sociedade que os designou como desprovidos de recursos de aprendizagens. A escola perante uma inclusão escolar leva o educando a ser incluído com qualquer tipo de déficit, garantindo sua estada e aquisição de conhecimentos necessários.

É preciso sair da inércia diante das modificações que devem ser realizadas nas escolas, perceber e se munir contra as barreiras que podem prejudicar as pessoas com necessidades especiais. Abrindo novas possibilidades, através de leituras e debates que possam sempre incluir as pessoas com deficiências, por conseguinte o todo, para formarmos cidadãos com igualitárias aprendizagens. 


\section{REFERÊNCIAS}

ALARCÃO, I. Professores Reflexivos em uma Escola Reflexiva. 8 ed. São Paulo: Cortez, 2011.

BRASIL. Lei Brasileira de Inclusão da Pessoa com Deficiência № 13.146, de 6 de julho de 2015 (Estatuto da Pessoa com Deficiência). Diário Oficial da União, Brasília, DF, fevereiro de 2021.

BRASIL. Lei de Diretrizes e Bases da Educação Nacional no 9.394, de 20 de dezembro de 1996. Diário Oficial da União, Brasília, DF, v. 134, n. 248, 23 dez. 1996. Seção 1, p. 2783427841

BRASIL. Constituição da República Federativa do Brasil. Brasília, DF: Senado Federal, 1988. Disponível em <http://www.planalto.gov.br. Acesso em 02 de mar 2021.

BRASIL. Declaração de Salamanca. Brasília, 1994. Disponível em:<http://portal.mec.gov.br /seesp/arquivos(pdf/salamanca/pdf.pdf> Acesso em: 02 de março de 2021.

BRASIL. Lei n.9.394, de 20 de dezembro de 1996. Diário Oficial da União, Brasília, DF, 23 dez.1996.

BRASIL/MEC/SEB: Parâmetros Curriculares Nacionais: introdução aos parâmetros curriculares nacionais. Brasil: MEC/SEF, 1997.

DANTAS, Heloysa. A afetividade e a construção do sujeito na psicogenética de Wallon. In LA TAILLE, Yves de. Piaget, Vygotsky, Wallon: teorias psicogenéticas em discussão. Yves de La Taille, Marta Kohl de Oliveira, Heloysa Dantas. São Paulo: Summus, 1992.

FREIRE, P. Pedagogia da Autonomia: saberes necessários à prática educativa. São Paulo: Paz e Terra, 1996.

LAKOMY, Ana Maria. Teorias Cognitivas da Aprendizagem. Curitiba: FACINTER, 2003.

MAHONEY, Abigail Alvarenga \& ALMEIDA, Laurinda Ramalho de. Afetividade e processo ensino-aprendizagem: contribuições de Henri Wallon. Revista da Psicologia da Educação, no 20 - 2005. Acesso: em 12 mar 2021.

Paulo, 2004.

A constituição da pessoa na proposta de Henri Wallon. Edições Loyola: São

MANTOAN, M.T.E. Inclusão Escolar- O que é? Por quê? Como fazer? São Paulo:

Summus, 2015.

MANTOAN, Maria Teresa Égler. O direito à diferença nas escola - questões sobre a inclusão escolar de pessoas com e sem deficiências. Revista Educação Especial; Santa Maria: UFSM, 23,2004. Disponível em < www.ufsm.br/ce/revista> acesso em: 08 de mar 2021.

MATTOS, S.M.N. A afetividade como fator de inclusão escolar. Teias, Rio de Janeiro, ano 9, no 18, pp. 50 59, julho/dezembro 2008. Disponível em:<http://www.periodicos.proped. pro.br/index.php/revistateias/article/viewFile/271/283. Acesso: 08 de mar 2021. 
MITTLER, P. Educação Inclusiva. Contextos Sociais. São Paulo: Artmed, 2003.

MUNIZ, Caroline Saback. A influência da relação afetiva no processo de escolarização. Disponível em: www.abpp.com.br/54.htm. Acesso em 12 mar de 2021.

NUNES, Vera. O papel das emoções na Educação. São Paulo: Casa do Psicólogo, 2009. Fonte: Brasil Escola. Disponível em: https://meuartigo.brasilescola.uol.com.br/educacao/aimportancia-afetividade-para-uma-aprendizagem-significativa.htm. Acesso em: 08 de mar 2021.

PIAGET, Jean: A Representação do mundo na Criança: com concurso de onze colaboradores. Aparecida, São Paulo: Ideias \& Letras, 2005.

RIBEIRO, Marinalva Lopes e JUTRAS, France. Representações Sociais de professores sobre afetividade. Estudos de Psicologia campinas, v.23, n. 1, p.39-45, mar 2006.

Disponível em: <http://www.scielo.php?script=sci.arttex\&pid> Acesso em: 02 de mar 2021.

SANTOS, M.P. Ressignificando a escola numa proposta inclusiva. Novembro de 2002. Disponível em http://www.educacaoonline.pro.br/ Acesso em 08 de mar de 2021

SCHAFFNER, C. Beth; BUSWELL, Barbara E. Dez elementos críticos para a criação de comunidades de ensino inclusivo eficaz. In: SATAINBACK, Susan; STAINBACK, Willian. Inclusão: um guia para educadores. Trad. Magda França Lopes. Porto Alegre. ARTES Medicas Sul, 1999. P. 69-87.

WALLON, H.: A evolução psicológica da criança. Lisboa: Ed. 70, 1978. 


\section{CAPÍTULO 13}

O PAPEL DA MEDIAÇÃO ESCOLAR INCLUSIVA

Fernando Icaro Jorge Cunha

Licenciando em Ciências da Natureza - Universidade Federal do Pampa - Unipampa

Perfil: http://lattes.cnpq.br/149558185211586

E-mail: icaro729@gmail.com

\section{Eleonora Leguiçamo Centena Silva}

Universidade da Região da Campanha - URCAMP

Perfil: http://lattes.cnpq.br/4873255525491550

E-mail: eleonora.centena@hotmail.com

\section{Janine Viven Nunes Quevedo}

Pontifícia Universidade Católica do Rio Grande do Sul - PUCRS

E-mail: j.jquevedo@hotmail.com

\section{Suélen De Prá Alves}

Pontifícia Universidade Católica do Rio Grande do Sul - PUCRS

E-mail: deprasuelem@gmail.com

\section{Karen Krystine Oldani Da Silva}

Pontifícia Universidade Católica do Rio Grande do Sul - PUCRS

Perfil: http://lattes.cnpq.br/5172731026216298

E-mail: karen_oldani@hotmail.com

\section{Maria José Baltar De Azambuja}

Escola Municipal Especial de ensino Fundamental Lygia Morrone Averbuck

Perfil: http://lattes.cnpq.br/8379431150091984

E-mail:mj.azambuja@bol.com.br

\section{Renata Pereira Vidal Da Silva}

Instituto Superior de Educação do Rio de Janeiro - ISERJ

Perfil: http://lattes.cnpq.br/6534572556531900

E-mail: rpereiravidal12@gmail.com

\section{Ivana Fontoura Carvalho}

Universidade Federal do Pampa - Unipampa

Perfil: http://lattes.cnpq.br/7291427235335414

E-mail: ivanafontouracarvalho@gmail.com

\section{Liliana Vieira Martins}

Centro de Produção da UERJ - CEPUERJ

Perfil: http://lattes.cnpq.br/3660548886422327

E-mail: lilith.vieira@gmail.com 


\section{Janete Hickmann}

Rede de Ensino Municipal de São Leopoldo - RS

Perfil: http://lattes.cnpq.br/0461298984464544

E-mail: janete22h@gmail.com

Resumo: Quando falamos em inclusão, logo nos vem à mente crianças "especiais" brincando e interagindo lindamente com o grupo escolar de sua sala de aula. Porém nem sempre o que imaginamos é real. As crianças incluídas, nem sempre conseguem realizar essa interação de forma harmoniosa, sendo necessária a mediação do professor para que isso ocorra. Nesse momento, passamos então a focar o papel do mediador na vida escolar das crianças inclusas. O professor desde os primórdios da história é o mediador, seja na sala de aula ou até mesmo na vida de seus alunos. Com o passar dos anos, mediar alunos tornou-se um verdadeiro desafio, afinal a desvalorização da classe, o avanço das mídias e a visão distorcida da sociedade que acredita que educação inclusiva é apenas inserir o aluno em uma escola básica e o professor deve acolher, sem sequer ter uma orientação para tal situação. Este capítulo é uma revisão bibliográfica que compara a perspectiva dos autores em função da literatura, bem como, professores em uma sucinta entrevista.

Palavras-chave: Inclusão; Mediação escolar; Professor; Escola. 


\section{INTRODUÇÃO}

Digamos que ao longo dos estudos universitários o professor aprenda de uma maneira muito geral sobre algumas necessidades especiais, logo ele passa a atuar e se depara com uma situação de inclusão, o que ele deveria fazer diante de tal fato, exigir que a escola o instrua a mediar esse aluno, ou acolher o mesmo, e ir aprendendo ao longo do ano.

Pois ele deveria ser instruído sim, mas não é, ele simplesmente acolhe o aluno e passa a ter um olhar mais específico, tentando compreender as suas necessidades ou até mesmo suas angústias.

O professor não sabe como lidar ainda com aquele aluno, ele faz movimentos, produz experiências e busca sempre oferecer a ele o mesmo que oferece aos alunos ditos "normais", afinal é assim que deve ser. Como a prática e a teoria nem sempre estão lado a lado, nesse momento o que "deveria" ser passa a ser o impossível, pois uma sala de aula com crianças sedentas pelo conhecimento, falando alto e questionando tudo, pode ser uma verdadeira tortura para aquele aluno lá do começo do texto, o aluno "especial", aquele que não suporta se que quer uma voz alta, imagina dezenas delas.

O que pode ser maravilhoso para uns pode ser destrutivo para o outro. discurso é lindo demais "viva a inclusão" mas cadê a sensibilidade de um grupo para direcionar o olhar mais voltado a mediação de fato. Precisamos deixar de romantizar a inclusão e mostrar aos professores soluções para que toda a turma consiga ser feliz e ter um aprendizado significativo.

Que tal se em conversa com os pais, fosse possível eles explorarem a necessidade real daquela criança, se juntos pensarem em como fazer aquela criança se sentir mais acolhida. De maneira nenhuma isso tem relação com os pais ensinarem o papel do professor, apenas uma maneira de dizer como as coisas funcionam em casa, e o quanto essa logística poderá ajudar de forma positiva na adaptação daquela criança, afinal o que falamos aqui é em parceria, isso não quer dizer que alguém sabe mais ou menos.

As redes de ensino teriam um grande êxito se decidissem gerar uma qualificação geral aos seus professores no que diz respeito à inclusão, pois teríamos profissionais mais "entendidos" consequentemente estes conseguiriam "dominar" 
melhor certas situações, tornando assim mais leve e mais agradável a permanência em sala de aula, afinal falamos em qualidade de ensino e não em quantidade. De acordo com Craidy e Kaercher:

Considerando que a criança permanecerá grande parte do seu dia neste local, devemos proporcionar um ambiente saudável, conforme as condições existentes para que esta criança também seja saudável (p. 39, 2001).

Quando falamos em qualidade, em um ambiente saudável, vários conceitos vêm à nossa cabeça, desde a higiene até mesmo o clima do local, porém no sentido de inclusão o que devemos levar em consideração é como fazer para que a criança se sinta acolhida. Vivemos realidades muito distintas, na rede pública e privada, mas o que precisamos é encontrar um jeito de tornar aquele local mais atrativo e acolhedor. Voltamos à importância de uma boa orientação pedagógica para que se tenha sucesso nessa acolhida, afinal a criança ali vai descobrir um novo mundo, e isso vale para todas as crianças, não somente as da inclusão.

Toda essa preocupação em tornar o ambiente mais "saudável" vai desde o espaço físico, sim porque não sabemos se essa criança vai precisar de mais espaço que as demais, ou se ela apenas precisará se adaptar à turma.

\section{A IMPORTÂNCIA DA QUALIFICAÇÃO PROFISSIONAL}

A verdade é que para todo o professor que será o mediador das crianças incluídas neste momento é muito desafiador, afinal não sabemos como essa criança receberá a escola, ou qual a vivência ela já carrega consigo, caso ela já esteja a mais tempo frequentando a escola. Contamos também com as expectativas da família, que carrega suas frustrações, medos e inseguranças.

Nesse sentido se torna necessária a qualificação dos profissionais da educação, porém essa é uma luta, e não uma conquista, sendo assim falaremos sobre a realidade das escolas, e como estamos lidando com os desafios que a educação inclusiva trás.

Hoje nossa realidade nos permite receber as crianças e seguir algumas das normas que a legislação nos oferece. Kauffman e Badar (2014) afirmam que, ao longo do século $X X$ e nas primeiras décadas do século $X X I$, foi tornando-se comum a ideia de que professores da educação especial devem trabalhar juntos com os professores do ensino regular, e que esta seria a melhor alternativa para a educação de todas as 
crianças com deficiência e com necessidades educacionais especiais. Entretanto, continuam os autores: [...] apesar desta ideia ter capturado a imaginação de muitos, as pesquisas não têm mostrado que tais práticas são realmente melhores que a instrução oferecida de forma direta, professor devidamente capacitado para suprir as necessidades de atendimento educacional especializado.

Ainda segundo esses autores, aqueles que questionam a eficácia da colaboração, consultoria e ensino compartilhado do currículo da educação geral apontam para a necessidade de instrução individualizada, focada, intensiva, persistente e especializada; instrução essa que apenas um professor bem treinado pode suprir (KAUFFMAN; BADAR, 2014).

Fica clara a necessidade de uma melhor preparação dos professores para o enfrentamento dessa grande luta em prol de uma educação inclusiva de qualidade. $\mathrm{Na}$ maioria das vezes o que falta não é saber mais, e sim conhecer qual a melhor maneira de atuar em determinadas situações, afinal sabemos que cada criança deve ser comparada com ela mesma, e com as crianças especiais não é diferente, elas podem ter a mesma patologia, e as reações podem ser as mais diversas, tudo depende de vários aspectos, um deles é a convivência familiar e as trocas que já foram ou não estabelecidas em outros momentos na vida escola.

Entendemos que o mediador é a peça chave no desenvolvimento do aluno que está inserido de forma inclusiva, pois ele vai ser aquele que mostra caminhos, que dará sugestões, e encontrará as soluções para tornar o ano letivo mais agradável possível.

O que esse professor mediador vai precisar além da vontade de ensinar que ele traz dentro de si, é a orientação necessária, para que consiga realizar um bom trabalho e tornar seu ambiente escolar, um lugar de alegria e muito conhecimento.

\section{O PAPEL DO MEDIADOR NA EDUCAÇÃO INCLUSIVA}

Ao conversarmos com especialistas no assunto inclusão, sobre o papel do mediador na vida das crianças, percebemos o quanto se faz necessária a criatividade acompanhada de uma boa interação com os pequenos, afinal são muitos os detalhes e curiosidades na individualidade de cada criança, por isso que o olhar atento e sensível é algo que poderá tornar o desenvolvimento destas crianças muito mais 
significativo, afinal o mediador nesse momento se torna fundamental, sendo ele capaz de proporcionar um ambiente para que as novas experiências aconteçam, tornando os desafios cada vez mais possíveis de serem alcançados. Mediadora em um centro de desenvolvimento para crianças incluídas e especialista em neurociências, Cassiana coloca sua opinião sobre a mediação na educação.

"O desenvolvimento integral da criança faz referência ao crescimento harmônico da aparelhagem e funcionalidade sensorial, perceptiva, psicológica, intelectual, motora, física e da linguagem. Quando ocorrem falhas ou atrasos neste processo chamamos de desenvolvimento atípico, enquadrando-se nestas crianças com transtornos, deficiências ou síndromes genéticas. Este crescimento ocorre especialmente durante as etapas críticas do desenvolvimento e maturação neuro cerebral do indivíduo.

A criança possui desde o nascimento um potencial de desenvolvimento que pode ser otimizado na medida em que os fatores biológicos e ambientais sejam favoráveis, ser entendido como produto da contínua interação entre as experiências vivenciadas, os fatores genéticos e o desenvolvimento biológico. Neste sentido, o papel do mediador nos mais diferentes ambientes é de extrema importância, pois ele amplia percepções, direciona a atenção da criança, a inclui socialmente nas brincadeiras com os pares e a ajuda a criar e construir habilidades e objetivos. Este princípio de mediação modifica substancialmente o papel do adulto, que passa a ser um facilitador de experiências.

Um bom mediador ou facilitador da aprendizagem na educação inclusiva deverá ser criativo e um especialista no uso dos recursos existentes, na formulação de perguntas geradoras de atividade mental e no enriquecimento do ambiente.

Com relação a criança, deverá ser capaz de evocar sua interação, conhecer suas destrezas e interesses percebendo suas expressões de prazer ou interesse, usando estas informações como aliado para favorecer o processo de mediação da aprendizagem".

- Qualidades Básicas de um Mediador da Aprendizagem:

- Conseguir um Nível Adequado De Empatia E Motivação;

- Saber observar;

- Saber "propor" Âmbitos De Experiências;

- Conhecer os Princípios Básicos do Desenvolvimento Evolutivo Da Criança"; 
Diante desse relato, passamos a acreditar ainda mais que as instituições sejam elas públicas ou privadas necessitam preparar mediadores para inclusão, não basta receber o aluno, é preciso dar-lhes condições de ensino, para que naquele ambiente em que ele está inserido independente do contexto, ele seja atingido de forma ampla e significativa, de maneira lúdica, criativa e acima de tudo prazerosa. Cada criança traz suas características, seus sonhos, suas experiências e expectativas, juntamente com suas famílias, o que não é diferente das demais crianças, então sejamos acolhedores e responsáveis por entregar a elas o nosso melhor, buscar conhecimento, instrução e meios de atingir os pequenos de uma forma capaz de tornar seu desenvolvimento melhor.

Uma das maneiras de tudo isso acontecer, é mostrar amor e profissionalismo, buscando sempre compreender que cada ser é único, que sua aprendizagem acontece das mais diferentes maneiras, por isso a sensibilidade e a criatividade são parceiras nesse processo.

Qualquer pessoa pode ser um mediador, mas somente uma pessoa comprometida com a educação inclusiva e com os desafios que ela carrega, poderá ser capaz de fazer a diferença na vida daquela criança, daquela família e daquela escola. Sejamos mediadores que mostram caminhos, sejamos acolhedores e entusiastas no que diz respeito à inclusão escolar. De acordo com FREIRE:

[...] A afetividade não me assusta, que não tenho medo de expressá-la. Significa esta abertura ao querer bem a maneira que tenho de autenticamente selar o meu compromisso com os educandos, numa prática específica do ser humano" (p.141, 1996).

A afetividade é algo que deve ser como se um pré requisito para os mediadores, para que eles possam atuar de forma mais humana, com mais gentileza não só com a criança, bem como com a sua família, como já foi dito antes. Falaremos sobre a importância da afetividade na inclusão escolar, como uma das melhores formas para conquistar a criança, dando a ela confiança e autonomia para que consiga ter uma vida escolar o mais simples possível, podendo assim não só interagir com a turma, mas também, realizar suas produções, mesmo com suas limitações. Ser um mediador afetuoso, é ter a certeza de poder tornar o caminho de uma criança mais cheio de significados, com boas memórias e aprendizagens que serão levadas para a vida toda. 
Temos o relato de uma mãe que cita a necessidade do filho, e conta um pouco da sua experiência com a escola, Carolina, servidora pública, que atua como professora, diz que:

"Para nós que convivemos com o autismo, com as particularidades desse transtorno, criamos expectativas e depositamos a nossa esperança na escola.

A escola pelo sentido de complementar uma rotina de contra turno das terapias, escola tem que somar, agregar, comprometer-se juntamente com a família no pleno desenvolvimento da criança.

Porém, a realidade não é essa, as crianças chegam à escola com suas particularidades, algumas limitações e inseguranças, e o educador infelizmente ainda não está preparado para esse acolhimento para um trabalho mais individualizado.

A inclusão requer tempo, estudo, disposição e amor. O sistema educacional precisa se renovar, começando pelo investimento dos profissionais. A criança precisa de auxiliar, e o auxiliar pode até estar ali, como é de seu direito, mas esse mesmo, não tem sequer alguma formação na área. Isso é um retrocesso! Todas as crianças especiais precisam de profissionais qualificados para juntamente com a família desenvolverem suas potencialidades".

Numa perspectiva de que todos têm direito à educação, independente de características físicas, intelectuais ou sensoriais e as instituições de ensino devem oferecer propostas pedagógicas de acordo com cada aluno, o professor por sua vez também deve ser preparado para trabalhar com diferentes tipos de sujeitos. Assim sendo o professor vai desempenhar seu papel de articulador no processo ensino aprendizagem, pois ele vai criar condições para concretizar a convivência e a aprendizagem dos alunos com ou sem deficiência no espaço da sala de aula, como também tornar explícitas as ações e interações entre a educação inclusiva e o sistema comum de ensino (BRASIL, 2020).

Um professor que reconhece e pratica a inclusão escolar vai desenvolver uma pedagogia mediadora e centrada na criança, na qual vai eliminar preconceitos e rótulos muito presentes na educação brasileira. Desse modo o professor vai utilizar metodologias e estratégias que promovam a aprendizagem de todos os educandos, independente de sua condição cognitiva. Ele vai deixar de ser mero executor de currículos com extensos conteúdos para oferecer atividades significativas que 
auxiliem os alunos no desenvolvimento de suas capacidades, considerando suas potencialidades e dificuldades de se apropriar do conhecimento.

O papel do professor na inclusão escolar não é fácil, mas quando ele atua sobre as peculiaridades dos alunos, provendo recursos, meios, equipamentos, linguagem e conhecimentos apropriados certamente irá suprir as necessidades de cada um no espaço escolar. Então, cabe ao professor compreender e respeitar os diferentes modos de aprendizado dos seus alunos, possibilitando na prática a verdadeira inclusão escolar, reafirmando a importância de todos serem reconhecidos em suas diferenças.

O processo de inclusão no âmbito escolar é um desafio que leva à realização de práticas pedagógicas dos profissionais que consideram cada aluno com parâmetro de si mesmo, com características e potencialidades próprias. Sendo que os alunos com deficiências (NEE) possuem os mesmos direitos que os outros "ditos normais" é necessário eliminar as barreiras excludentes que dificultam ainda mais aos alunos especiais que adquirirem os mesmos conhecimentos básicos e essenciais para que consigam com autonomia uma melhor qualidade de vida em todos os sentidos. Com a inclusão dos alunos com deficiências nas classes regulares de ensino as escolas, bem como os profissionais que atuam nelas são desafiados a proporcionar métodos e ferramentas adequadas que levem todos os alunos independentes de nível cognitivo e construírem aprendizagens significativas para seu desenvolvimento integral.

A escola inclusiva deve ser aquela que respeita o tempo e ritmo dos alunos, proporcionando meios para que possam se desenvolver e ampliem suas possibilidades, garantindo que o processo de inclusão possa fluir da melhor maneira possível com responsabilidade de todos envolvidos no dia a dia da escola atendendo a diversidade da clientela escolar. Sabe-se que o professor é o mediador entre o aluno e o conhecimento, sendo assim cabe a ele promover situações pedagógicas em que os alunos com necessidades educacionais especiais superem o senso comum e avance em seu potencial humano, afetivo, social e intelectual, quebrando as barreiras que se impõem.

Farfus (2008), afirma que: A articulação entre os educadores é urgente, pois existe a necessidade de uma redefinição do papel do professor e de sua forma de atuar, no pensamento sistêmico. 
Um ponto inicial para uma proposta inclusiva em sala de aula é que os professores mudem a visão de incapacidade das pessoas com necessidades especiais, para uma visão pautada nas possibilidades, organizando atividades variadas, dando importância no respeito às diferenças e às inteligências múltiplas.

O professor é o mediador, ele é que busca inúmeras estratégias e possibilidades para chegar até $o$ aluno e juntos construírem aprendizagens significativas.

Cada estudante é um ser único que se desenvolve de diferentes maneiras, quando o professor tem um olhar atento e sensível os resultados certamente serão significativos.

O simples fato das crianças ditas "especiais" estarem incluídas em aulas normais já é uma enorme conquista para todos nós, eu digo todos porque acredito muito que todos nós temos algo a ensinar e a aprender, cabe ao professor entender e fazer a diferença na vida de todas as crianças que chegam até ele.

\section{CONSIDERAÇÕES FINAIS}

Os professores que buscam uma ação educativa, devem estar atentos às diversidades dos seus alunos, pois cada um tem sua maneira de entender e internalizar o que é passado a ele. O professor deve exercer seu papel de maneira justa e solidária, dando importância ao respeito mútuo, eliminando todo e qualquer tipo de discriminação com o intuito de formar cidadãos conscientes para o convívio com as diferenças.

O professor deve focalizar o "saber" de como trabalhar em aula e incluir o aluno com necessidades especiais, tem que ter aquele olhar mais sensível para entender a metodologia que será usada com esse aluno.

Um aspecto que o professor tem que estar atento para que possa tomar decisões educacionais que afetam os alunos com necessidades especiais é o nível de interação que estes alunos estabelecem com seus colegas e a sua auto estima, por isso, essas atividades programadas para eles têm que favorecer não somente suas aprendizagens, mas também a relação com os colegas e o valor do trabalho pessoal. 
Sendo que esses alunos têm a oportunidade de exercitar um de seus direitos fundamentais como cidadãos ao direito à educação. Por tanto a prática educativa com os alunos com necessidades especiais demanda muitas revisões por parte dos professores, tanto as de natureza pragmática, situadas nos diversos aspectos que mobilizam o cotidiano escolar, como as de natureza teórica. Sendo assim é a aproximação entre teoria e prática que pode qualificar a educação de qualquer grupo de alunos.

Segundo Paulo Freire: "O caminho para a construção do conhecimento, de certo, não pode ser trilhado por um viajante solitário, portanto, o professor e seus alunos devem caminhar juntos nesta estrada".

O processo da construção do conhecimento relaciona-se ao contexto do aluno e como ele compreende um problema a ser resolvido, daí a relação entre quem ensina e quem aprende para ir gradativamente aumentando os desafios a serem superados, e dessa forma construir e reconstruir novos conhecimentos.

Nesse contexto de ensinar e aprender, a inclusão no ensino, como em todos os seguimentos da sociedade é uma fonte de enriquecimento em nossas práticas pedagógicas onde devemos reorganizar nossos currículos, nossas metodologias, bem como nosso relacionamento com esses sujeitos que possuem diferentes vivências para promover o crescimento e possibilitar-lhes aprendizagens vida a fora. 


\section{REFERÊNCIAS}

BRASIL. Ministério da Educação. Educação Especial, MEC lança documento sobre implementação da PNEE Política estabelece ampliação da educação especial, 2020.

Disponível em: https://www.gov.br/mec/pt-br/assuntos/noticias/mec-lanca-documento-sobreimplementacao-da-pnee-1 Acesso em: 30/06/2021.

CRAIDY, Carmem Maria; KAERCHER, Gládis Elise P. da Silva. Educação Infantil: pra que te quero. Porto Alegre: Artes Médicas, 2001.

FREIRE, P. Pedagogia da autonomia: saberes necessários à prática educativa.São Paulo: Paz e Terra, 1996.

UNESCO. Educação para Todos. Brasilia: Biblioteca virtual de Educação Unesco-Brasil, 2003.

PERRENOUD, Philippe. Pedagogia diferenciada: das intenções à ação. Porto Alegre: Artmed, 2000. 


\section{CAPÍTULO 14}

A LUTA HISTÓRICA PELA INCLUSÃO ESCOLAR: UM DESAFIO ÁRDUO PELA CONQUISTA DE IGUALDADE E RESPEITO

Maria José Baltar De Azambuja

Escola Municipal Especial de ensino Fundamental Lygia Morrone Averbuck

Perfil: http://lattes.cnpq.br/8379431150091984

E-mail:mj.azambuja@bol.com.br

\section{Fernando Icaro Jorge Cunha}

Universidade Federal do Pampa - Unipampa

Perfil: http://lattes.cnpq.br/149558185211586

E-mail: icaro729@gmail.com

\section{Leonice Aparecida De Fátima Alves Pereira Mourad}

Universidade Federal de Santa Maria - UFSM

Perfil: http://lattes.cnpq.br/7689442989367017

E-mail: profleomourad@gmail.com

\section{Janete Hickmann}

Rede de Ensino Municipal de São Leopoldo - RS

Perfil: http://lattes.cnpq.br/0461298984464544

E-mail: janete22h@gmail.com

\section{Joel De Almeida Nunes}

Universidade Luterana do Brasil, ULBRA

Perfil: http://lattes.cnpq.br/0869118201801878

E-mail: professordematematicams@gmail.com

Resumo: O presente estudo tem por objetivo apresentar a visão de diferentes autores sobre o desafio de incluir verdadeiramente os alunos portadores de deficiências nas escolas brasileiras. O conceito de inclusão vem sendo discutido no Brasil sob diferentes perspectivas e enfoques teóricos. O processo de inclusão escolar tem como pressuposto a mobilização da sociedade para um novo olhar frente às diferenças humanas, elegendo-as como um valor assumido por todos, uma vez que a principal característica do ser humano não é a igualdade e sim a pluralidade. A perspectiva primordial da inclusão é a certeza de que não existem pessoas iguais e são exatamente as diferenças que caracterizam os seres humanos. O aluno é então compreendido como um ser único, social, que tem sua história de vida. Assim, à medida que temos uma posição de respeito frente às diferenças humanas, vamos construindo espaços em que as posturas de segregação vão perdendo campo de atuação e deixando de influenciar as práticas pedagógicas discriminatórias.

Palavras-chave: Desafio de incluir; Escola e sociedade; Pluralidade. 


\section{INTRODUÇÃO}

A inclusão social e educacional é hoje um movimento mundial que vem se intensificando particularmente a partir da década de 90.

Falar em inclusão é pensar em uma inovação escolar, é ressignificar o ensino tradicional e excludente buscando a integração dos alunos portadores de necessidades especiais.

Incluir nos obriga a refletir e repensar o sistema educacional a partir da mudança de nossos pensamentos e ações educativas, garantindo o acesso, a permanência e a participação de todas as crianças nas várias esferas da vida escolar, respeitando, valorizando a diversidade, coibindo a segregação, o isolamento e a exclusão.

A inclusão não é um processo rápido e fácil, mas requer uma mudança atitudinal e uma preparação adequada de todos aqueles que atuam junto aos educandos nas escolas brasileiras.

Diante disso, este estudo propõe refletir através da pesquisa bibliográfica acerca do direito de todos à educação, entendendo que as diferenças estão sendo constantemente feitas e refeitas e que estão em todos e em cada um.

Pretende-se ainda, destacar se alguns princípios básicos para a efetivação da inclusão, tais como o acesso dos alunos com necessidades educacionais especiais às classes comuns, a verdadeira inclusão desses alunos na sociedade e na escola, a aprendizagem conjunta mesmo tendo objetivos e processos diferentes, e a formação dos professores para 0 atendimento real desses alunos, estão realmente acontecendo.

\section{A LONGA E DIFÍCIL TRAJETÓRIA DAS PESSOAS COM DEFICIÊNCIAS}

Em primeiro lugar, é preciso definir com clareza o termo "deficiência", para evitar distorções comuns ao lidar com essa área de conhecimento. Por efeito de lei, considera-se deficiência "toda perda ou anormalidade de uma estrutura ou função psicológica, fisiológica ou anatômica que gere incapacidade para o desempenho de atividades, dentro do padrão considerado normal para o ser humano". (BRASIL, 2009, p. 1) 
As pessoas com deficiências foram historicamente se constituindo como incapazes, defeituosas, problemáticas, pouco eficientes, isto Ihes constituiu status inferior diante das pessoas consideradas não deficientes.

No caso das crianças pequenas, essa situação foi agravada por causa da representação da infância como uma réplica miniaturizada do adulto, como alguém incompetente, inacabado, incapaz de atuar no mundo sem ajuda de outro.

Desse modo a criança deficiente foi duplamente penalizada socialmente, reforçando-se os estereótipos que a colocam numa situação de inferioridade e incapacidade diante dos adultos e das pessoas que não possuem deficiências.

Apesar dos poucos registros anteriores à Idade Média, sabe-se que na Antiguidade as crianças que nasciam com algum tipo de deficiência eram consideradas sub-humanas, eliminadas ou abandonadas à morte.

Com a expansão do cristianismo pela Europa, passaram então a ser consideradas "pessoas", dotadas de alma e não mais eliminadas, mas continuaram a ser estigmatizadas pela sociedade.

Lentamente, as questões relacionadas às pessoas com deficiências passaram a ser do interesse médico. Os médicos-cientistas, a partir do século XVI, passam a buscar as origens das características dessas pessoas.

Nessa época os portadores de deficiências ainda eram isolados, careciam de cuidados e de total atendimento educacional.

No final do século XVIII, surgem instituições especializadas para surdos e cegos, dando início ao atendimento educacional especializado.

Somente no século XIX os pedagogos entraram em cena, Jean Itard, Edouard Séguin, Maria Montessori, entre outros, iniciaram suas atividades na medicina, deslocando seu enfoque para a educação.

No início do século XX, com a ampliação dos processos de escolarização, aumenta $\mathrm{o}$ interesse pelas limitações associadas às deficiências, particularmente à deficiência mental, surgindo a educação especial como tratamento dessas pessoas.

Em 1948, com a declaração dos direitos humanos, apontando a "igualdade de direitos", inicia-se a história da Educação Inclusiva, recebendo em toda sua trajetória diversas nomenclaturas: educação especial, educação inclusiva e integração.

Ao final da década de 60 , iniciou-se o movimento pela integração social com o objetivo de "[...] inserir as pessoas com deficiência nos sistemas sociais gerais como 
a educação, o trabalho, a família e o lazer [...]," (SASSAKI, 2010, p.31), processo este mais vivenciado na década de 80.

A sociedade em todas as culturas atravessou diversas fases no que se refere às práticas sociais. "[...] começou praticando a exclusão social de pessoas que por suas condições atípicas não the pareciam pertencer à maioria da população e em seguida desenvolveu o atendimento segregado dentro de instituições, passando à prática de integração social e recentemente adotou a filosofia de inclusão social para modificar os sistemas sociais gerais". (SASSAKI, 2010, p. 16).

\subsection{Educação Inclusiva e Legislação Brasileira}

No Brasil, "[...] a constituição da República Federativa de 1988, assumiu formalmente, os mesmos princípios da Declaração Universal dos Direitos Humanos, que assegura às pessoas com deficiências os mesmos direitos à liberdade, a uma vida digna, à educação fundamental, ao desenvolvimento pessoal e social e a livre participação na vida e na comunidade". (BRASIL, 2009, p.15-18).

Em março de 1990, o Brasil participou da Conferência Mundial sobre Educação para Todos, em Jomtien, Tailândia, na qual foi proclamada a Declaração de Jomtien, onde os países relembram que a educação é um direito fundamental de todos e que a educação é de fundamental importância para o desenvolvimento das pessoas e das sociedades contribuindo para um mundo mais sadio e próspero favorecendo o progresso social, econômico e cultural, a tolerância e a cooperação internacional.

A partir de 1994, durante um congresso na cidade de Salamanca, Espanha, a educação regular e a educação especial passaram a ser encaradas como um único sistema, os alunos com necessidades especiais deveriam passar a frequentar a sala de aula junto com os demais alunos do ensino regular.

A legislação mais atual sobre o assunto é a Convenção de Guatemala, de 28 de maio de 1999. O documento promulgado no Brasil, por decreto de 2001, reafirma que as pessoas com deficiência têm os mesmos direitos que os demais, proibindo qualquer forma de exclusão ou restrição baseada na deficiência da pessoa, considerando tal prática como crime.

O Brasil é signatário desse documento, que foi aprovado pelo Congresso nacional por meio do Decreto Legislativo no 198, de 13 de junho de 2001, e 
promulgado pelo decreto n 3.956, de 8 de outubro de 2001, da Presidência da República.

A importância dessa convenção está no fato de que deixa clara a impossibilidade de diferenciação com base na deficiência, definindo a discriminação como:

[...] toda diferenciação, exclusão ou restrição baseada em deficiência, antecedente de deficiência, consequência de deficiência anterior ou percepção de deficiência presente ou passada, que tenha o efeito ou propósito de impedir ou anular o reconhecimento, gozo ou exercício por parte das pessoas portadoras de deficiência de seus direitos humanos e suas liberdades fundamentais ,art. $1^{\circ}, \mathrm{n}^{\circ} 2$ "a" (MANTOAN, 2012, p. 24).

A Constituição Federal Brasileira de 1988 e a Lei de Diretrizes e Bases da Educação Nacional 9394/96, trouxe dispositivos para assegurar a inserção de pessoas portadoras de deficiências preferencialmente na rede regular de ensino, garantindo-Ihes ainda, o atendimento educacional especializado.

Além dessas leis acima citadas, é preciso destacar o Estatuto da Criança e do Adolescente, de 13 de julho de 1990; a Lei Federal № 7.855, de 24 de outubro de 1989 que, entre outras medidas, criou a Coordenadoria Nacional para a Integração da Pessoa Portadora de Deficiência.

Atualmente a Educação Inclusiva Brasileira está vivendo um novo momento com o Plano Nacional de Educação (PNE) que estabelece as metas a serem alcançadas até 2020, para que se faça uma educação mais republicana, universal, inclusiva e de qualidade para as gerações presentes e futuras.

De acordo com Santos (2006), apud Fávero (2011, p. 25):

Temos o direito a sermos iguais quando a diferença nos inferioriza; temos o direito a sermos diferentes quando a igualdade nos descaracteriza. Daí a necessidade de uma igualdade que reconheça as diferenças e de uma diferença que não produza, alimente ou reproduza as desigualdades.

\section{DIFERENÇA NA CONTEMPORANEIDADE}

Apesar do avanço da ciência, vivemos em um tempo em que os seres humanos mostram-se cada vez mais intolerantes ao diferente, ao mais fraco, ao menos esperto, ao mais lento.

O avanço da ciência é tanto, que hoje, em pleno século $X X I$, existe a possibilidade de reconstruir ou remodelar corpos adoecidos, mutilados, envelhecidos ou simplesmente fora dos padrões estéticos estabelecidos, através de substâncias químicas, cirurgias, implantes, enfim. Mais ainda, é 
possível gerar novas vidas humanas em laboratório, prescindindo da relação corpo a corpo. (BRAUNER, 2009, p. 86).

Assim, é possível através do conhecimento científico procurar entender o funcionamento do organismo e da inteligência do homem. É fato, portanto, que o homem moderno está em constante busca da saúde do corpo. Os gregos e romanos da antiguidade, também possuíam preocupação com a saúde, para eles cuidar da saúde corporal era uma questão de responsabilidade com a família. Para o homem de hoje, cuidar bem da saúde não inclui o outro, apenas a si mesmo, como diz Moraes (2011, p. 80), "o homem do século XXI não prepara seu corpo para seduzir o outro, senão para apresentar-se a si mesmo".

Dessa forma, como pensar em inclusão, quando o que o mundo propõe é apagar as diferenças.

Se refletirmos um pouco os problemas relativos à educação inclusiva na contemporaneidade, não se referem mais àquelas crianças e adolescentes que nasceram com alguma patologia: síndromes, paralisias, deficiências intelectuais. Referem-se a todos aqueles que escapam ao nosso conhecimento: se movimenta demais; é muito agitado; sabe muito e aprende muito rápido; sabe contar dinheiro, mas não sabe ler e escrever; é muito pobre e vem para a escola sujo e sem organização pessoal; é muito rico e tem tudo, mas é desorganizado e não obedece às regras escolares. Trata-se de diferenças que confrontam o saber do mestre. (MORAES, 2011, p.81).

Consequentemente, são questionados a formação e os apoios oferecidos, sejam eles institucionais, jurídicos, políticos ou sociais. Não podemos então deixar de pensar em qual será a formação ideal ao professor do século XXI, em como proteger e respeitar nossas crianças, como formar o outro desde a e na sua singularidade, como ensinar sem robotizar, sem querer transformar o aluno naquilo que ele não é e por fim, como pensar as relações entre a inclusão ideal e a inclusão real.

\section{INCLUSÃO IDEAL OU INCLUSÃO REAL}

De acordo com Vygotsky (2010, p. 97).

As aprendizagens são produtos das elaborações compartilhadas, ou seja, das trocas significativas que ocorrem na sala de aula, precisamente em torno dos objetos de conhecimento. Objetos esses, que são o próprio corpo, os materiais pessoais, a socialização, as necessárias negociações entre os pares e entre professor/aluno, inclusive a construção das letras e dos números.

Partindo desse pressuposto a escola possui dois objetivos: um, de natureza acadêmica e outro relativo às interações sociais. Portanto, se um aluno não possui 
objetivos de natureza acadêmica, deve haver uma troca entre este, o professor, o terapeuta da criança e a família, a fim de dar conta de suas demandas pessoais e de aprendizagem e para que 0 docente construa suas estratégias de intervenção e adaptações curriculares para todo o grupo de alunos. Segundo Paez (2010) apud Moraes (2011, p. 30), "[...] atender a diversidade é atender as crianças com deficiências incapacitantes, mas também todas as outras diversidades que aparecem cotidianamente na comunidade".

A escola precisa adequar-se aos seus alunos, com a finalidade maior de inserilos na sociedade, tornando-os cidadãos, respeitando e acolhendo as diferenças, atingir a todos sem ser excludente. É indispensável que a escola elimine as barreiras arquitetônicas, pedagógicas e sociais, adotando práticas de ensino escolar adequadas às diferenças dos educandos, oferecendo equipamentos especializados aos alunos com e sem deficiências.

O acesso ao ensino deve ser assegurado a todos, bem como a permanência na escola, respeitando a capacidade de cada um, com práticas escolares que contemplem a todos. Todos os cursos de formação de professores devem oferecer ao professor, consciência e preparo para que recebam em suas aulas, alunos portadores ou não de deficiências. Só assim, o abismo que há entre o real e o ideal poderá ser reduzido em nossa realidade educacional, levando nossas escolas e universidades a uma prática inclusiva verdadeira e não apenas integradora.

\section{INCLUSÃO OU INTEGRAÇÃO}

Discutir a respeito da integração e da inclusão cria infindáveis polêmicas, mexe com os professores, com os profissionais da área da saúde que atuam no atendimento aos portadores de deficiências e principalmente com as associações de pais.

"Os professores do ensino regular consideram-se incompetentes para lidar com as diferenças nas salas de aula, especialmente atender os alunos com deficiência, pois seus colegas especializados sempre se distinguiram por realizar unicamente esse atendimento e exageram essa capacidade de fazê-lo aos olhos de todos", diz (MORAES, 2011, p. 88). 
Existem também, alguns pais de alunos que não possuem deficiências, que são contra a inclusão, pois acreditam que se a escola aceitar alunos portadores de necessidades especiais não haverá qualidade no ensino .

Mantoan (2012, p. 15) explica que: "integração e inclusão, enquanto tenham significados semelhantes, são empregados para expressar situações de inserção diferentes".

\begin{abstract}
O processo de integração ocorre dentro de uma estrutura educacional que oferece ao aluno a oportunidade de transitar no sistema escolar- da classe regular ao ensino especial- em todos os seus tipos de atendimento: escolas especiais, classes especiais, em escolas comuns, ensino itinerante, salas de recursos, classes hospitalares, ensino domiciliar e outros. Trata-se de uma concepção de inserção parcial, porque o sistema prevê serviços educacionais segregados. (MANTOAN, 2012, p. 15).
\end{abstract}

Normalmente, os alunos que migram das escolas comuns para os serviços de educação especial, raramente voltam às salas de aula do ensino regular.

Nem todos os alunos com deficiências são integrados ao ensino regular, alguns participam de turmas com currículos adaptados, avaliações especiais, e redução dos objetivos educacionais.

Segundo Mantoan (2012, p. 16) "integração escolar pode ser entendida como o "especial na educação", ou seja, a justaposição do ensino especial ao regular, ocasionando um inchaço desta modalidade, pelo deslocamento de profissionais, recursos, métodos e técnicas da educação especial às escolas regulares".

Já a inclusão implica uma mudança de perspectiva educacional, pois não atinge apenas alunos com deficiência e os que apresentam dificuldade de aprender, mas todos os demais. A maioria dos que fracassam na escola, não vêm do ensino especial, mas possivelmente acabarão nele, a inclusão exige uma mudança, as escolas devem atender a todos sem segregar. (MANTOAN, 2012, p. 16).

\title{
6. ENCANTAMENTO E ESTRANHAMENTO
}

Vimos que durante séculos, muitos foram eliminados, exterminados, os fracos, doentes, loucos, idiotas ou marginais, oferecidos aos animais, queimados em fogueiras, aprisionados, apagados de várias formas por serem diferentes.

Hoje, as leis humanas não permitem mais que tais fatos aconteçam, do ponto de vista jurídico e educacional, existem propostas para inserir, incluir, possibilitando a todos seres humanos os mesmos direitos. 
Para Brauner (2009, p. 82) "[...] tais leis não asseguram a erradicação do preconceito, senão que apenas limitam ou transformam as ações humanas".

Mesmo com os movimentos que buscam dignidade e respeito humano, o que vemos é um aumento da violência e desrespeito às leis, um ataque não mais aos loucos, doentes ou idiotas e sim um ataque às nossas crianças.

Brauner (2009, p. 83) ainda questiona; "qual seria o destino dos fracos, loucos e doentes do nosso século? O diferente seriam as crianças? Parece que a infância, já não produz mais encantamentos, senão estranhamentos".

Se em pleno século XXI, a infância está perdendo espaço para uma sociedade que valoriza acima de tudo a imagem perfeita como objeto da felicidade e trabalha para apagar os traços de incompletude da infância, o que dizer das crianças que nascem com alguma patologia, parece que aos olhos da atual sociedade, causam elas apenas estranhamento.

De acordo com Brauner (2009, p. 83) "[...] é fundamental e urgente, uma renegociação dos valores que a criança contemporânea está pagando para poder existir".

É, portanto, papel da escola atual, das universidades e dos profissionais da educação, acolher as novas gerações em toda sua diversidade cultural, étnica, religiosa, física e psíquica, promovendo o direito à igualdade de oportunidades.

\begin{abstract}
As crianças são completas, mesmo quando se apresentam de modos diferentes. Elas têm um corpo, espírito, emoções, criatividade, identidade histórica e social. Para se tornarem sujeitos, elas precisam e querem se relacionar com outras crianças e adultos, pois somos seres interdependentes.Viver, aprender, comunicar, são ações que envolvem encantamentos e relacionamentos, direitos fundamentais das crianças. Este é o papel da escola, tornar as crianças verdadeiros cidadãos, construir uma escola verdadeiramente inclusiva, para termos uma sociedade menos desigual, onde a criança possa existir sem causar estranhamento. (SOUZA, 2009, p. 87).
\end{abstract}

\title{
7. O DESAFIO DA INCLUSÃO
}

A inclusão é um desafio, porém não é uma tarefa fácil, mas é possível, desde que o desafio de incluir seja um compromisso da escola e de todos aqueles que tomam parte dela.

A educação é também onde decidimos se amamos nossas crianças o bastante para não expulsá-las de nosso mundo e abandoná-las a seus próprios recursos e tampouco, arrancar de suas mãos a oportunidade de empreender alguma coisa nova e imprevista para nós, preparando-as, em 
vez disso e com antecedência, para a tarefa de renovar um mundo comum (ARENDT, 2010, p. 9).

A maioria das escolas está longe ainda de se tornar realmente inclusiva, o que existe, são escolas com projetos de inclusão parcial que continuam atendendo os alunos portadores de necessidades especiais em espaços escolares segregados.

As escolas que não estão atendendo alunos com deficiência em suas turmas de ensino regular se justificam, na maioria das vezes, pelo despreparo dos seus professores para esse fim. Outras não acreditam nos benefícios que esses alunos irão tirar da nova situação, especialmente os casos mais graves, pois não iriam acompanhar os avanços dos demais (MANTOAN, 2012, p. 46).

Fica então evidente a necessidade de se redefinir e se colocar em prática novas alternativas pedagógicas, que favoreçam a todos educandos, o que implica na atualização de conceitos e em práticas escolares que estejam de acordo com esse desafio.

Mudar a escola exige muitos desafios, é preciso haver transformações para que a escola cumpra seu papel educacional e social, visando um ensino de qualidade e realmente inclusivo.

7.1 O desafio de transformar a escola

Fávero (2011, p. 46) diz que temos que agir urgentemente:

É preciso colocar a aprendizagem como eixo das escolas, porque escola foi feita para fazer com que todos os alunos aprendam, assegurar tempo e condições para que todos possam aprender de acordo com o perfil de cada um e reprovando as repetências, garantir 0 atendimento educacional Especializado, preferencialmente na própria escola comum da rede regular de ensino, abrir espaços para que a cooperação, o diálogo, a solidariedade, a criatividade e o espírito crítico sejam exercitados por toda a comunidade escolar e por fim, estimular, formar continuamente e valorizar o professor, que é o responsável pela tarefa fundamental da escola - a aprendizagem dos alunos.

Em escolas verdadeiramente inclusivas, as crianças e adolescentes com deficiências não precisam e não devem estar fora das turmas comuns de ensino regular, desde a Educação Infantil ao Ensino Médio.

A adoção de práticas educacionais alternativas para melhorar as condições do ensino nas escolas regulares, devem fazer parte da organização pedagógica da escola para que essas possam se abrir incondicionalmente às diferenças. 
Não existe mágica, o desafio está em se encarar a inclusão de todos na escola comum, como um compromisso inadiável com o seu preparo para o exercício da cidadania e a qualificação para o trabalho, garantidos pela Constituição Federal Brasileira.

\title{
7.2 O desafio de estar na escola
}

Espera-se que todas as crianças que fazem parte da sociedade atual possam ir à escola, embora em alguns países essa prática ainda não seja garantida.

Sacristán (2008) apud Moraes (2011, p. 105) afirma:

O fato de estar escolarizado, é uma vivência que marca o caráter, a condição social daqueles que estão na sala de aula, a aceitação no mundo e seu futuro. E esta é uma experiência que nem todos têm em igualdade de condições, durante o mesmo tempo e na mesma especialidade. Assim, se é aluno de formas bem diferentes e com distintas projeções em função da qualidade da experiência que cada um tiver.

Algumas pessoas acreditam que as crianças com necessidades especiais são membros novos na comunidade escolar, apesar de 'os diferentes' sempre terem feito parte da mesma, porém pouco reconhecidos e tratados de outras formas.

\begin{abstract}
A escola que temos em nossas representações de adultos não traz em seu interior, muito provavelmente, alunos com necessidades especiais, porque estes sujeitos não estavam lá quando lembramos dos espaços escolares de nossa infância. Isto, faz pensar se não está aí a dificuldade no processo de inclusão dessas crianças (MORAES, 2011, p.18).
\end{abstract}

Seria simples pensar, que se sustentarmos por um longo tempo na escola ou na sociedade, as crianças com necessidades especiais, o processo de inclusão se tornará mais fácil, porque assim, então, todas as crianças farão parte da "paisagem natural" da escola.

De uma maneira geral, estar na escola para grande parte dos educadores, é compor um grupo social de crianças que tenham a mesma idade, comportamentos e aprendizagens desejadas onde todos devem aprender o que a escola ensina dentro de um mesmo tempo, quando isso não ocorre aparece o rótulo do diferente.

Precisamos entender que lidamos com seres humanos e interagir com crianças que estão à nossa frente, ouvindo-as, observando aquilo que produzem, sem julgar o que é correto ou válido, levando-as a interagir umas com as outras.

Para qualquer criança, a entrada na escola amplia imensamente as possibilidades de compartilhar ações com seus pares. Ela é um espaço privilegiado e 
inquestionável de aprendizagem, socialização, interação e encontro com o outro, quer seja o outro portador de necessidades especiais ou não. (MORAES, 2011, p. 22)

As crianças desejam estar umas com as outras, aprendem sobre si mesmas e sobre os outros compartilhando experiências, interagindo entre elas, portanto, estar na escola para a criança com necessidades especiais ou não, deve ser um desafio, um universo de socialização.

Nos processos de socialização das crianças Moraes (2011, p. 25) observa que "[...] surgem as desigualdades simbólicas, produzidas no interior do grupo de pares por via das divisões sociais do trabalho e do conhecimento que marca um lugar social".

Diz ainda Moraes (2011, p. 28) "a forma como as crianças se apresentam socialmente, seus corpos, os objetos que trazem para mostrar, as roupas que vestem, tornam-se um marcador social, "olha o que eu trouxe" neste contexto surge como sinônimo de "olha quem sou".

Podemos perceber com clareza na citação da autora, movimentos de exclusão sendo reproduzidos entre as crianças na escola.

Nas pesquisas de Bronfman e Martines (2006), encontramos algumas semelhanças com o trabalho de Moraes, mas também diferenças importantes.

Diferente do que Moraes acredita, Bronfman e Martines (2006) apud Moraes (2011, p. 30) afirmam que "[...] a ideia de que a diferença causa rechaço necessariamente entre as crianças, pode ser mais uma generalização dos adultos de uma determinada cultura e momento histórico".

Na verdade, o desafio de estar na escola é para todos aqueles que fazem parte da sociedade e principalmente do professor, que não deve excluir nenhum aluno de suas aulas, das atividades e do convívio escolar, deve ensinar a todos sem discriminações, fazendo uso de práticas pedagógicas que se ajustem aos novos parâmetros da educação.

\section{CONSIDERAÇÕES FINAIS}

Este estudo propôs refletir acerca do processo de inclusão e a maneira pela qual o mesmo está acontecendo, pois incluir tem como objetivo a construção de uma escola acolhedora, onde não existam critérios ou exigências de natureza alguma, nem mecanismos de seleção ou discriminação para o acesso e a permanência com sucesso de todos os alunos na escola. 
Entretanto, as reflexões e estudos aqui socializados não têm a pretensão de servir de receita, mas sim de mostrar que a inclusão tal qual a construção do conhecimento, é um processo individual e coletivo, que envolve não somente a razão, mas igualmente a emoção, o desejo, a intuição e a construção de um caminho que não está pronto, mas que se faz ao caminhar.

Ficou evidente no estudo que o caminho a percorrer para uma inclusão real e ideal é longo e cheio de barreiras, principalmente as atitudinais, pois atitudes de rejeição e descrença em relação aos alunos portadores de deficiências ainda são muito frequentes.

No atual cenário político-econômico brasileiro deparamo-nos com a desvalorização do magistério, a má formação de alguns educadores, a inexistência em algumas escolas do Projeto Político Pedagógico que contemple a diversidade dos alunos, a falta de recursos que auxiliem nas aprendizagens, o descaso de muitas famílias com a educação de seus filhos e ainda com a vulnerabilidade social em que muitos se encontram.

Embora cientes de todas essas dificuldades não se pode esquecer que vivemos um processo de mudança político, social e educacional, ainda lento, mas que já trouxeram muitos avanços em nossa forma de ver aqueles que necessitam ser incluídos.

Desta forma, entendemos que o processo de inclusão escolar de alunos com necessidades educacionais especiais nas classes regulares é possível quando se acredita no potencial humano, na alegria que a diferença pode significar entre as pessoas.

Os desafios são muitos, mas a inclusão representa antes de tudo, uma filosofia de vida, é preciso entender que todos somos diferentes e que monótono seria a igualdade.

Confirmando esta ideia Beyer afirma que:

"O desafio é construir e pôr em prática no ambiente escolar uma pedagogia que consiga ser comum ou válida para todos os alunos da classe escolar, porém capaz de atender aos alunos cujas situações pessoais e características correspondentes requeiram uma pedagogia diferenciada. Tudo isso sem demarcações, preconceitos ou atitudes nutridoras dos indesejados estigmas. Ao contrário, pondo em andamento, na comunidade escolar, uma conscientização crescente dos direitos de cada um" (2008, p. 88). 


\section{REFERÊNCIAS}

ARENDT, Hannah. A Condição Humana. $11^{\underline{a}}$ ed. Rio de janeiro: Forense Universitária, 2010.

BEYER, H. O. Por uma epistemologia das crianças com necessidades especiais. Revista da educação Especial. V3. Brasília: Secretaria de educação Especial, 2008.

BRASIL, Ministério da Educação. Secretaria de Educação. O acesso de alunos com deficiência às classes comuns da rede regular de ensino. Brasília: MEC, 2009.

BRAUNER, Maira F. A queda do muro: símbolo da liberdade ou denúncia da exclusão? Ciências \& letras, Porto Alegre, n.46, dez. 2009.

FÁVERO, E.A.G. Direitos das pessoas com deficiência: garantia de igualdade na diversidade. Rio de Janeiro: WVA, 2011. LAKATOS. Eva Maria; MARCONI. Marina de Andrade.Fundamentos de metodologia Científica. São Paulo: Atlas, 2003.

MANTOAN, Maria Teresa Égler. Inclusão escolar: O que é? Por quê? Como fazer? São Paulo: Moderna, 2012.

MORAES, Salete Campos. Educação inclusiva: diferentes significados. Porto Alegre: EVANGRAF, 2011.

SASSAKI, R. Inclusão: construindo para todos uma sociedade. Rio de janeiro, WVA, 2010.

SOUZA, F. R. O lugar das diferenças e a configuração dos espaços escolares. Porto Alegre: UFRGS, 2009.

VYGOTSKY, Lev. S. A formação social da mente. São Paulo: Martins Fontes, 2010. 


\section{CAPÍTULO 15}

TECNOLOGIAS ASSISTIVAS: POTENCIALIZANDO HABILIDADES

APRESENTADAS POR ESTUDANTES DA EDUCAÇAÕ ESPECIAL INCLUSIVA

Fernando Icaro Jorge Cunha

Licenciando em Ciências da Natureza - Universidade Federal do Pampa - Unipampa

Perfil: http://lattes.cnpq.br/149558185211586

E-mail: icaro729@gmail.com

\section{Luciana Martins Vieira}

Escola Municipal Especial de Ensino Fundamental Lygia Morrone Averbuck

Perfil: http://lattes.cnpq.br/4916051022113025

E-mail: lumartinsv@gmail.com

\section{Leonice Aparecida De Fátima Alves Pereira Mourad}

Universidade Federal de Santa Maria - UFSM

Perfil: http://lattes.cnpq.br/7689442989367017

E-mail: profleomourad@gmail.com

\section{Maria José Baltar De Azambuja}

Escola Municipal Especial de Ensino Fundamental Lygia Morrone Averbuck

Perfil: http://lattes.cnpq.br/8379431150091984

E-mail:mj.azambuja@bol.com.br

\section{Caroline Pugliero Coelho}

Universidade Federal do Pampa - UNIPAMPA/Campus Uruguaiana

Perfil: http://lattes.cnpq.br/1138015620367845

E-mail: carolinecoelho.aluno@unipampa.edu.br

\section{Janete Hickmann}

Rede de Ensino Municipal de São Leopoldo - RS

Perfil: http://lattes.cnpq.br/0461298984464544

E-mail: janete22h@gmail.com

Resumo: Este trabalho desenvolve-se por meio de uma revisão bibliográfica, em uma reflexão sobre as Tecnologias Assistivas. Pessoas com deficiências ou com mobilidade reduzida, em sua maioria necessitam de um subsídio maior na mediação de atividades específicas para o desenvolvimento de habilidades e potencialidades. Os novos caminhos oportunizados pelas tecnologias assistivas, oportunizam o despertar da autonomia do educando. O estudo das tecnologias assistivas, desde a fundamentação à aplicação, é de âmbito multidisciplinar, e os resultados da mediação correta, resulta na melhor qualidade de vida, independência e maior facilidade de adaptações. Os recursos são variados, desde um sapato ortopédico, até um computador adaptado.

Palavras-chave: Inclusão; Tecnologia assistiva; Recursos; Adaptações. 


\section{INTRODUÇÃO}

A temática da denominada tecnologia assistiva está diretamente associada ao esforço contemporâneo de inclusão das pessoas com necessidades especiais. Tal fato decorre da necessária inclusão eficiente que em razão da diversidade impõe aos educadores um conjunto ampliado de desafios, cabendo destacar que profissionais de várias áreas da educação e da saúde estão diretamente envolvidos com a promoção da educação inclusiva, dentre elas: Terapia Ocupacional, Fisioterapia, Fonoaudiologia, Psicologia e Psicopedagogia.

Já existe um conjunto importante de estudos que salientam a centralidade da utilização de ferramentas tecnológicas como computadores, tablets e aplicativos específicos para pessoas que necessitam de instrumentos diferenciados para aprender, sendo que nem sempre esses são utilizados. O contexto em que vivemos, em plena crise sanitária provocada pela COVID 19 percebemos o reduzido acesso nas escolas públicas a esses meios, sendo expressivos os trabalhos que apontam essa situação que é substancialmente agravada quando referimos pessoas com necessidades especiais.

A Tecnologia Assistiva é uma área de conhecimento multidisciplinar, que prevê o acesso a recursos, dos mais avançados até os de complexidade básica, que permitem que pessoas com deficiência e/ou dificuldade possam realizar atividades que, sem tais adaptações, não seriam possíveis (BRASIL, 2008).

O direito à educação e aos Recursos de Tecnologia Assistiva, necessários ao aprendizado para as pessoas com deficiência, encontra garantia legislativa em um conjunto ampliado de dispositivos legais, merecendo destaque a Lei 13.146/2015, conhecida como Lei Brasileira de Inclusão.

No seu artigo 10 encontramos:

É instituída a Lei Brasileira de Inclusão da Pessoa com Deficiência (Estatuto da Pessoa com Deficiência), destinada a assegurar e a promover, em condições de igualdade, o exercício dos 32 direitos e das liberdades fundamentais por pessoa com deficiência, visando à sua inclusão social e cidadania (BRASIL, 2015).

No artigo 28, item VII o legislador regulamentou a questão educacional estabelecendo que fica assegurado:

Planejamento de estudo de caso, de elaboração de plano de atendimento educacional especializado, de organização de recursos e serviços de 
acessibilidade e de disponibilização e usabilidade pedagógica de recursos de tecnologia assistiva (BRASIL, 2015).

Destacamos também que nas Diretrizes Nacionais para a Educação Especial Básica, encontramos os fundamentos, os princípios da educação inclusiva e orientam a organização das escolas para realizarem a inclusão de educandos com deficiência, sendo fundamental a formulação de estratégias para que todos sejam incluídos de forma equânime no espaço escolar.

Brito (2006), enfatiza importância de as equipes escolares refletirem sobre a inserção de tecnologias nos processos inclusivos; Dias e Cavalcante (2016), apontam que a equipe de educadores envolvida no processo de inclusão de educandos com necessidades específicas, tem por dever repensar sua prática, de forma a aderir aos meios digitais de inclusão, proporcionando novos alicerces para a educação inclusiva; Carvalho e Carvalho (2017) assinalam as contribuições da utilização de recursos tecnológicos em sala de aula, favorecendo a maior qualidade do ensino e da aprendizagem dos sujeitos envolvidos.

\section{CATEGORIAS DAS TECNOLOGIAS ASSISTIVAS}

A classificação que segue foi escrita originalmente em 1998 por José Tonolli e Rita Bersch e sua última atualização é de $2017^{1}$. Ela tem uma finalidade didática e em cada tópico considera a existência de recursos e serviços. Esta proposta de classificação foi desenhada com base nas diretrizes gerais da ADA, em outras classificações utilizadas em bancos de dados de TA e especialmente a partir da formação dos autores no Programa de Certificação em Aplicações da Tecnologia Assistiva - ATACP da California State University Northridge, College of Extended Learning and Center on Disabilities. (SARTORETTO, 2020).

\footnotetext{
${ }^{1}$ José Tonolli e Rita Berch. Assistiva Tecnologia e Educação. Porto Alegre-RS, 2017.
} 
Tabela 1: Categorias das Tecnologias Assistivas

\begin{tabular}{|c|c|}
\hline $\begin{array}{l}1 \\
\text { Auxílios para a vida } \\
\text { diária }\end{array}$ & $\begin{array}{l}\text { Materiais e produtos para auxílio em tarefas rotineiras tais como comer, cozinhar, } \\
\text { vestir-se, tomar banho e executar necessidades pessoais, manutenção da casa } \\
\text { etc. }\end{array}$ \\
\hline $\begin{array}{l}2 \\
\text { Comunicação } \\
\text { aumentativa } \\
\text { (suplementar)e } \\
\text { alternativa }\end{array}$ & $\begin{array}{l}\text { Recursos, eletrônicos ou não, que permitem a comunicação expressiva e receptiva } \\
\text { das pessoas sem a fala ou com limitações da mesma. São muito utilizadas as } \\
\text { pranchas de comunicação com os símbolos PCS ou Bliss além de vocalizadores } \\
\text { e softwares dedicados para este fim. }\end{array}$ \\
\hline $\begin{array}{l}\text { Recursos de } \\
\text { acessibilidade ao } \\
\text { computador }\end{array}$ & $\begin{array}{l}\text { Equipamentos de entrada e saída (síntese de voz, Braille), auxílios alternativos de } \\
\text { acesso (ponteiras de cabeça, de luz), teclados modificados ou alternativos, } \\
\text { acionadores, softwares especiais (de reconhecimento de voz, etc.), que permitem } \\
\text { às pessoas com deficiência usarem o computador. }\end{array}$ \\
\hline $\begin{array}{l}4 \\
\text { Sistemas de controle de } \\
\text { ambiente }\end{array}$ & $\begin{array}{l}\text { Sistemas eletrônicos que permitem às pessoas com limitações moto-locomotoras, } \\
\text { controlar remotamente aparelhos eletro-eletrônicos, sistemas de segurança, entre } \\
\text { outros, localizados em seu quarto, sala, escritório, casa e arredores. }\end{array}$ \\
\hline $\begin{array}{l}5 \\
\text { Projetos arquitetônicos } \\
\text { para acessibilidade }\end{array}$ & $\begin{array}{l}\text { Adaptações estruturais e reformas na casa e/ou ambiente de trabalho, através de } \\
\text { rampas, elevadores, adaptações em banheiros entre outras, que retiram ou } \\
\text { reduzem as barreiras físicas, facilitando a locomoção da pessoa com deficiência. }\end{array}$ \\
\hline$\stackrel{6}{\text { Órteses e próteses }}$ & $\begin{array}{l}\text { Troca ou ajuste de partes do corpo, faltantes ou de funcionamento comprometido, } \\
\text { por membros artificiais ou outros recursos ortopédicos (talas, apoios etc.). Inclui- } \\
\text { se os protéticos para auxiliar nos déficits ou limitações cognitivas, como os } \\
\text { gravadores de fita magnética ou digital que funcionam como lembretes } \\
\text { instantâneos. }\end{array}$ \\
\hline $\begin{array}{c}7 \\
\text { Adequação Postural }\end{array}$ & $\begin{array}{l}\text { Adaptações para cadeira de rodas ou outro sistema de sentar visando o conforto } \\
\text { e distribuição adequada da pressão na superfície da pele (almofadas especiais, } \\
\text { assentos e encostos anatômicos), bem como posicionadores e contentores que } \\
\text { propiciam maior estabilidade e postura adequada do corpo através do suporte e } \\
\text { posicionamento de tronco/cabeça/membros. }\end{array}$ \\
\hline $\begin{array}{l}8 \\
\text { Auxílios } \\
\text { de mobilidade }\end{array}$ & $\begin{array}{l}\text { Cadeiras de rodas manuais e motorizadas, bases móveis, andadores, scooters de } \\
3 \text { rodas e qualquer outro veículo utilizado na melhoria da mobilidade pessoal. }\end{array}$ \\
\hline $\begin{array}{l}9 \\
\text { Auxílios para cegos ou } \\
\text { com visão subnormal }\end{array}$ & $\begin{array}{l}\text { Auxílios para grupos específicos que inclui lupas e lentes, Braille para } \\
\text { equipamentos com síntese de voz, grandes telas de impressão, sistema de TV } \\
\text { com aumento para leitura de documentos, publicações etc. }\end{array}$ \\
\hline $\begin{array}{l}10 \\
\text { Auxílios para surdos ou } \\
\text { com déficit auditivo }\end{array}$ & $\begin{array}{l}\text { Auxílios que incluem vários equipamentos (infravermelho, FM), aparelhos para } \\
\text { surdez, telefones com teclado - teletipo (TTY), sistemas com alerta táctil-visual, } \\
\text { entre outros. }\end{array}$ \\
\hline $\begin{array}{l}11 \\
\text { Adaptações em veículos }\end{array}$ & $\begin{array}{l}\text { Acessórios e adaptações que possibilitam a condução do veículo, elevadores para } \\
\text { cadeiras de rodas, camionetas modificadas e outros veículos automotores usados } \\
\text { no transporte pessoal }\end{array}$ \\
\hline
\end{tabular}

Fonte: Os autores 


\section{TECNOLOGIA ASSISTIVA COMO RECURSO PARA ALUNOS ESPECIAIS}

A Tecnologia assistiva é um recurso utilizado atualmente para tornar a vida das pessoas com deficiências, mais funcional, mais fácil e independente, promovendo assim, uma vida com melhor qualidade ao indivíduo.

Cook e Hussey definem a Tecnologia Assistiva (TA), citando o conceito do ADA - American with Disabilities Act, como uma ampla gama de equipamentos, serviços, estratégias e práticas concebidas e aplicadas para minorar os problemas funcionais encontrados pelos indivíduos com deficiências. (COOK \& HUSSEY, 1995).

O termo Assistive Technology, traduzido no Brasil como Tecnologia Assistiva, foi criado como importante elemento jurídico dentro da legislação norte-americana conhecida como Public Law 100-407 e foi renovado em 1998 como Assistive Technology Act de 1998 (P. L. 105,394, S 2432). Compõe, com outras leis, o ADA American With Disabilities Act, que regula os direitos dos cidadãos com deficiência nos EUA, além de prover a base legal dos fundos públicos para compra dos recursos que estes necessitam.

Recurso é todo e qualquer item, equipamento ou parte de equipamento, utilizado para melhorar ou manter as capacidades funcionais das pessoas com deficiências, podem variar de uma simples bengala a um sistema computadorizado.

Estão incluídos brinquedos e roupas adaptadas, computadores, softwares e hardwares especiais, que contemplam questões de acessibilidade, dispositivos para adequação da postura sentada, recursos para mobilidade manual e elétrica, equipamentos de comunicação alternativa, chaves e acionadores especiais, aparelhos de escuta assistida, auxílios visuais, materiais protéticos e milhares de outros itens confeccionados ou disponíveis comercialmente. (SARTORETTO, 2020).

A utilização de recursos de Tecnologia Assistiva remonta a pré-história, onde um pedaço de pau poderia se tornar uma bengala improvisada.

Os recursos de tecnologia assistiva estão muito próximos do nosso dia-a-dia. Ora eles causam impacto devido à tecnologia que apresentam, ora passam quase despercebidos. Para exemplificar, podemos chamar de tecnologia assistiva uma bengala, utilizada por nossos avós para proporcionar conforto e segurança no momento de caminhar, bem como um aparelho de amplificação utilizado por uma pessoa com surdez moderada ou mesmo veículo adaptado para uma pessoa com deficiência. (MANZINI, 2005, p. 82). 
São incontáveis os recursos simples e de pouco custo que podem ser disponibilizados nas escolas, conforme as especificidades de cada aluno com necessidades educativas especiais.

São exemplos destes recursos: suportes para visualização de textos ou livros; fixação do papel ou caderno na mesa com fitas adesivas; engrossadores de lápis ou caneta confeccionados com esponjas enroladas e amarradas, ou com punho de bicicleta ou tubos de PVC "recheados" com epóxi; substituição da mesa por pranchas de madeira ou acrílico fixadas na cadeira de rodas; órteses diversas, e inúmeras outras possibilidades. (GALVÃO, 2009)

Como faz notar Bersch, "a aplicação da Tecnologia Assistiva na educação vai além de simplesmente auxiliar o aluno a 'fazer' tarefas pretendidas. Nela, encontramos meios de o aluno 'ser' e atuar de forma construtiva no seu processo de desenvolvimento" (BERSCH, 2006, p. 92).

Portanto, é importante utilizar recursos de Tecnologia Assistiva quando pensamos em Educação Especial Inclusiva, somente com materiais adaptados às diferentes necessidades de cada aluno, as escolas irão oferecer uma educação realmente inclusiva e de qualidade.

\section{CONSIDERAÇÕES FINAIS}

As tecnologias assistivas são recursos ou serviços proporcionados a fim de contribuir para ampliar as habilidades funcionais das pessoas com deficiência. Seu objetivo maior é promover uma vida independente e autônoma para as pessoas com deficiência. Tais tecnologias podem ser identificadas nos mais diversos contextos do cotidiano, e são divididas em várias categorias, como por exemplo, vida diária e prática, projetos arquitetônicos para promoção de acessibilidade, órteses, próteses e, mais voltado para a área educacional, a comunicação alternativa e recursos de acessibilidade ao computador.

A utilização das tecnologias assistivas no contexto educacional são de fundamental importância, pois a partir delas se desenvolvem muitas habilidades dentro do processo de ensino e aprendizagem. Dessa forma otimizando muitas potencialidades dos alunos e oferecendo diversas possibilidades para o planejamento docente. Para além das questões educacionais, o uso das tecnologias assistivas 
desenvolvem na criança, além da independência e autonomia, a autoconfiança e motivação, fatores de suma importância para alunos e professores.

É notável as diversas potencialidades que encontramos na utilização das tecnologias assistivas dentro do contexto escolar. Ao pensá-las e utilizá-las o docente percebe as necessidades reais do aluno, planeja suas ações e adapta materiais e recursos com o propósito de promover uma real inclusão dentro da sua sala de aula. Podemos concluir que esta tecnologia dá suporte para a ação docente tanto nos processos de estimulação sensoriais e motoras quanto nas questões de desenvolvimento social e mental, ressignificando as capacidades dos alunos.

A inclusão educacional é uma realidade que ainda precisa ser muito discutida pelos profissionais da educação, pois a inclusão não se respalda apenas em leis e decretos, para que ela seja efetivada dentro das escolas é necessário um olhar singular e planejamento individualizado para cada aluno, respeitando as suas imitações e enaltecendo as suas potencialidades. Nesse contexto pode-se afirmar os benefícios das tecnologias assistivas dentro do grande processo de ensino e aprendizagem das pessoas com deficiência. 


\section{REFERÊNCIAS}

BERSCH, R. Tecnologia assistiva e educação inclusiva. In: Ensaios Pedagógicos, Brasília: SEESP/MEC, p. 89-94, 2006.

BRASIL. Lei no 13.146 de 6 de julho de 2015. Diário Oficial da União. Brasília: p.2, 07/07/2015.

Subsecretaria Nacional de Promoção dos Direitos da Pessoa com Deficiência. Comitê de Ajudas Técnicas. Tecnologia Assistiva - Brasília: CORDE, 2008, 138p.

BRITO, Glaucia da Silva. Tecnologias para transformar a educação. Educar em Revista, n. 28, p. 279-282, 2006.

CARVALHO, Rosiane. As tecnologias no cotidiano escolar: possibilidades de articular o trabalho pedagógico aos recursos tecnológicos. 2017.

DIAS, Graciele Alencar; DE ALENCAR CAVALCANTE, Rosiane. AS TECNOLOGIAS DA INFORMAÇÃO E SUAS IMPLICAÇÕES PARA A EDUCAÇÃO ESCOLAR: UMA CONEXÃO EM SALA DE AULA. Revista de Pesquisa Interdisciplinar, v. 1, n. Esp, 2017

GALVÃO FILHO, Teófilo Alves. Tecnologia para uma Escola Inclusiva. 2009. Disponível em: https://repositorio.ufba.br/ri/bitstream/ri/10563/1/Tese\%20Teofilo\%20Galvao.pdf Acesso em: 07. mar. 2021.

MANZINI, E. J. Tecnologia assistiva para educação: recursos pedagógicos adaptados. In: Ensaios pedagógicos: construindo escolas inclusivas. Brasília: SEESP/MEC, p. 82-86, 2005.

ROCHA, A. N. D. C.; DELIBERATO, D. Tecnologia assistiva para a criança com paralisia cerebral na escola: identificação das necessidades. Revista Brasileira de Educação

Especial. v. 18, n. 1, p. 71-92, 2011

SARTORETTO, M. L. Tecnologia e Educação. 2020. Disponível em: https://www.assistiva.com.br/tassistiva.html Acesso em: 07. mar. 2021. 


\section{CAPÍTULO 16}

ENSINO DE GEOGRAFIA INCLUSIVO: A LINGUAGEM CARTOGRÁFICA COMO RECURSO DE COMUNICAÇÃO

\section{Tuane Telles Rodrigues}

Universidade Federal de Santa Maria

Perfil: htttp://lattes.cnpq.br/5487178721406774

E-mail: tuanytel@hotmail.com

\section{Leonice Aparecida de Fátima Alves Pereira Mourad}

Universidade Federal de Santa Maria

Perfil: http://lattes.cnpq.br/7689442989367017

E-mail: andrehaiske@gmail.com

Resumo: O presente artigo trata da Cartografia Escolar e a inclusão de alunos cegos e surdos, priorizando a democratização dos conteúdos geográficos, sendo que a Cartografia Inclusiva assume um papel importante nesse processo de inclusão. O objetivo do presente artigo é realizar uma discussão com base em atividades realizadas em uma escola de educação especial de Santa Maria, RS/Brasil sobre como o processo de comunicação entre a Cartografia Escolar e os alunos surdos possibilita a compreensão de uma grande variedade de conteúdos geográficos.

Palavras-chave: Cartografia inclusiva; Alunos surdos e geografia; Geografia escolar. 


\section{INTRODUÇÃO}

Figurando entre os temas mais abordados em grandes eventos de Ensino de Geografia, a inclusão escolar tem ganhado destaque. Dentre os conteúdos da Geografia que melhor se aproximam dessa discussão, chama a atenção a Cartografia Escolar.Seus conteúdos tem bastante aplicabilidade com alunos cegos e surdos, sendo esse o público alvo de nossa pesquisa.

O ensino de Geografia tem experimentado mudanças teóricas e metodológicas que buscam situar o aluno como sujeito social, agente do espaço e centro de vivências acerca do lugar. Tais transformações vêm permitindo um processo de constante aperfeiçoamento e mudança da Geografia enquanto disciplina escolar, inclusive em seus aspectos epistemológicos.

Se considerarmos que esta ciência estuda determinadas relações entre os seres humanos e a relação destes com a natureza, entenderemos que é necessário ao professor desta disciplina o compromisso com a sociedade. Castrogiovanni e Goulart (1998, p. 130) dizem que a Geografia Escolar deve levar o aluno a entender o espaço, a historicidade da das sociedades e o território a partir de interesses e contradições, assim como compreender os modos de apropriação humana dos elementos desigualmente distribuídos da natureza (recursos). Segundo os autores, "a territorialidade implica localização, orientação e representação dos elementos (dados) socioeconômicos e naturais".

Buscando democratizar o acesso aos conteúdos geográficos, as pesquisas geoeducacionais vão ao encontro das propostas inclusivas que melhor se adequa ao pensamento geográfico, e sugerem, com base em conhecimentos de análises físicas e socioespaciais, ferramentas que dialogam com os discentes, procurando a inserção cada vez maior de alunos de diferentes comunidades nas reflexões e propostas metodológicas de ensino. Há nessas pesquisas o propósito de estimular a iniciativa e a criticidade sobre o arranjo social presente, proporcionando e abrindo, de forma permanente, espaços de manifestação dos anseios dos alunos.

São variados os conteúdos que integram o ensino de Geografia, que abrange os mais diversificados ramos e escalas de análise. Contudo, a Cartografia Escolar constitui-se como a base essencial para dar forma às informações, estruturando e concretizando (por meio dos mapas) informações, e assim, dando forma ao 
pensamento geográfico. Ela possibilita a contextualização de diferentes objetos de estudo através de representações planas, em diferentes escalas de aproximação, bem como a organização, a apresentação, a comunicação e a utilização da geoinformação. É nesse contexto que a Cartografia assume um relevante papel na inclusão escolar, uma vez que se vem concretizando a construção de métodos focados na inserção de alunos com necessidades especiais. Denominamos Cartografia inclusiva essa tendência teórica. Ela tem como objetivo proporcionar aos alunos uma alfabetização cartográfica mediada por recursos adaptados às suas necessidades, a exemplo dos sujeitos surdos e deficientes auditivos que fazem uso da língua brasileira de sinais. Nesse caso, ainda que seja necessário conhecer conceitos cartográficos e muitos alunos possuam pouco ou nenhum conhecimento da língua portuguesa, as representações cartográficas possibilitam leituras de apelo didático. Objetivamos no presente artigo realizar uma discussão - com base em atividades realizadas em uma escola de educação especial de Santa Maria, RS/Brasil

- sobre como o processo de comunicação entre a Cartografia Escolar e os alunos surdos possibilita a compreensão de uma grande variedade de conteúdos geográficos.

\section{ENSINO DE GEOGRAFIA NO CONTEXTO INCLUSIVO}

As transformações históricas do ensino de Geografia têm repercutido de forma variada, seja nas discussões sobre a organização dos conteúdos presentes nos livros didáticos, seja na construção dos Parâmetros Curriculares Nacionais de Geografia (PCN's), em 1997, o que trouxe novas perspectivas sobre a importância social do estudo de Geografia no ensino fundamental, apontando e sugerindo temas relevantes para a sala de aula. Cabe destacar também os assíduos debates sobre a formação de professores, que envolvem, entre outras coisas, aspectos epistemológicos da ciência geográfica e a constante atualização técnica e instrumental dos profissionais docentes.

Nesse sentido, tem destaque a discussão sobre o papel da Geografia na Educação Especial e as suas contribuições para o desenvolvimento dos alunos com necessidades especiais. Nesse contexto, abordam-se noções de orientação, lateralidade, localização, entre outras, e propostas que envolvem ferramentas que 
favoreçam o acesso dos alunos. Podemos citar como exemplos o trabalho do Laboratório de Cartografia Tátil (LABTATE) da Universidade Federal de Santa Catarina (UFSC), onde são criados recursos em Braille para o ensino de Geografia e a alfabetização cartográfica de alunos cegos ou com baixa visão e também os trabalhos realizados pelo PIBID Geografia do curso de Geografia da Universidade Federal de Santa Maria (UFSM), que realizou algumas atividades inclusivas (mais frequentes entre 2012 e 2015) também para alunos cegos, assim como pesquisas mais recentes (2019) realizadas no curso de Pós-Graduação em Geografia. A dissertação de mestrado intitulada "O jogo digital como recurso didático na alfabetização cartográfica de alunos surdos e deficientes auditivos em Santa Maria, RS/Brasil" apresentou à comunidade o jogo digital tridimensional chamado "CartoCon: Nossa Expedição Geográfica", que utiliza vídeos em Libras para a comunicação com os alunos surdos e deficientes auditivos, além de permitir a realização de atividades voltadas à alfabetização cartográfica e ao ensino de Geografia.

O processo ensino-aprendizagem exige métodos que permitam a elaboração e a ressignificação de conceitos cotidianos. Também requer uma interação maior entre o professor e o aluno, cabendo ao docente a responsabilidade pela adequação da mediação pedagógica e a aplicação constante de novos recursos em prol da aprendizagem do discente. A este cabe manifestar seus anseios, vivências e dificuldades de aprendizagem. Conforme afirma Callai (1986, p. 27), para que se possa avançar e fazer da Geografia algo interessante deve-se [...] saber o que queremos com o ensino da geografia [...], tendo claro o caminho que seguiremos para isto e conhecer de forma mais completa o espaço a ser estudado e ensinado".Ao professor cabe a função de ampliar o conhecimento pessoal trazido pelo aluno para o ambiente escolar e fazer as conexões com os saberes já produzidos. Para que isso aconteça, faz-se necessário que o docente da área da Geografia vá além do que se aprende durante a formação inicial, inovando, modernizando, e capacitando-se pedagogicamente (por exemplo: cursos de Libras, ferramentas pedagógicas digitais, teorias contemporâneas de aprendizagem, Educação Especial, entre outros). Tal investimento pode promover a criação de modos alternativos de ensinar e auxiliar na compreensão sobre o modo com o que o aluno aprende.

Quando a porta da sala de aula sinaliza para muitos alunos a entrada em um lugar isolado de outras realidades, onde a interlocução não é considerada como 
estratégia de ensino, e sim a reprodução rígida e passiva de informações, a ação pedagógica perde o sentido, não propiciando o efetivo desenvolvimento e o envolvimento de todos. Lembremos as palavras de Bachelard (2004, p. 87), para quem "o educador que sonha os sonhos da Razão Educativa não teme a morte da Pedagogia, porque deseja verdadeiramente o bem-viver e sua sabedoria consiste em empenhar-se na busca do sentido para sua vida e para a educação". Com isso, o educador procura pedagogizar a vida para dar mais vida à educação. Quando utilizamos o termo "inclusão" nos referimos a uma grande variedade de indivíduos e suas diferenças, seja a cor da pele; seja a questão econômica, com a preservação e manutenção das instituições públicas, gratuitas e prezando sempre por sua qualidade; seja a vida religiosa, que diz respeito ao pertencimento cultural; seja a sexualidade, cuja discussão tem implicações importantes em relação ao mundo dos direitos e às liberdades; seja o acesso de alunos com deficiência às instituições de ensino regulares ou o seu desejo de permanecer em escolas de Educação Especial. A inclusão é uma tentativa de tornar a escola um lugar de convívio, aprendizado social e respeito às individualidades mais íntimas do ser.

Ao considerarmos a escola como um espaço de movimento e interação entre diferentes culturas e entre singularidades, é nosso dever, enquanto cidadãos e profissionais da educação, garantir a efetivação dos direitos humanos na medida em que se transformam e se adaptam às realidades contemporâneas, lutar pela sua manutenção e pela democratização nas escolas e no convívio diário. Estimular a reflexão para que as nossas crianças e adolescentes possam manter a esperança na solidariedade, na generosidade e na justiça social a partir da convivência e das atividades diárias. É necessário ter em vista que não basta ensinar os princípios da Declaração Universal dos Direitos Humanos, é preciso vivenciá-los e apreciá-los. A dialogicidade, à vista da Geografia, representa dar o lugar de fala ao indivíduo e às comunidades, significa proporcionar em todos os momentos o espaço para o diálogo. Quando apresentamos conceitos aos alunos (espaço, paisagem, território, lugar etc) não podemos dissociar tais noções daquilo que é percebido pelo sujeito na perspectiva de sua história, sua realidade, sua cultura. Para tanto, é preciso entender a relação intrínseca entre o que se aprende como e aquilo que é experienciado pelo sujeito, objetivando a construção do conhecimento e instigando a criticidade, muito necessária nos tempos atuais. 


\section{RELAÇÃO ENTRE A LINGUAGEM CARTOGRÁFICA E A LIBRAS}

Segundo Castellar (2005, p. 216), a Cartografia é considerada uma linguagem por ser constituída como "um sistema-código de comunicação imprescindível em todas as esferas da aprendizagem em Geografia, articulando fatos, conceitos e sistemas conceituais", permitindo ler e escrever as características do território em forma de representação. No mesmo sentido, Cavalcanti (2005, p. 88) diz que a Geografia "desenvolveu uma linguagem, um corpo conceitual, que acabou por constituir-se numa linguagem geográfica. Essa linguagem está permeada por conceitos que são requisitos para a análise dos fenômenos do ponto de vista geográfico". Para a autora, a Cartografia aparece não apenas como técnica ou tópico de conteúdo, mas como linguagem que apresenta códigos, símbolos e signos próprios. Essa linguagem deve ser apreendida pelo aluno "para que ele possa se inserir no processo de comunicação representado pela Cartografia (uma ciência da transmissão gráfica da informação espacial) e desenvolver as habilidades fundamentais de leitor de mapas e de mapeador da realidade" (ibid., p. 9).

A linguagem cartográfica se apresenta mediante signos decifráveis aplicados às representações visuais, como a legenda e os sinais convencionais, ou a própria espacialização de um determinado fenômeno sobre a superfície de uma imagem. Os signos exercem uma função relevante na compreensão das representações expostas nos mapas, sejam temáticos ou sistemáticos, pois eles remetem a leitura dos símbolos empregados que mostram na linguagem cartográfica um significado específico. Nesse sentido, Castellar (2005) diz que a criança vivencia o processo de letramento cartográfico ao compreender as noções, a forma de ler e de elaborar mapas mentais, experimentando atividades simbólicas como, por exemplo, entender o "significado dos símbolos e signos que correspondem aos fenômenos que são representados nos desenhos e que estão relacionados e agrupados para que possa ser organizada uma legenda" (ibid., p. 215).

Cerne da Cartografia Escolar, a linguagem cartográfica é capaz de estabelecer a comunicação de informações sobre as mais variadas relações físico-naturais e sociais. A Cartografia e seu apelo artístico, juntamente com os rigores convencionais do mapeamento, disponibiliza ao leitor o contato cognoscente com realidades de outro modo difíceis de apreender, converte informações e possibilita interpretações 
apuradas quando em interação com o aparato cognitivo do sujeito. É um recurso promissor quando aplicado ao ensino de Geografia para alunos surdos, tendo em vista o sofisticado processo de decodificação visual que a comunidade surda dispõe. A transcrição de palavras através da datilologia e a utilização de classificadores são os recursos mais utilizados para comunicação pelos surdos, nos quais os aspectos visuais são evidentes, inclusive na relação semiótica, de natureza icônica, estabelecida entre o classificador e o objeto a ele correspondente. Compreender a articulação entre a linguagem cartográfica e a língua brasileira de sinais permite um melhor planejamento do ensino de Geografia aos alunos surdos. Nesse sentido, a utilização de produtos cartográficos adequados contribui para a construção do conhecimento geográfico e a aplicação de conteúdos pertinentes à formação do pensamento crítico.

É interessante mencionar que em nossa experiência na oficina realizada na escola, sobre a qual referimos, a interpretação dos códigos e informações visuais nos mapas ocorreu de um modo particularmente rápido, antes mesmo de um processo contínuo de alfabetização cartográfica. Isso parece corroborar a hipótese de que o processamento visual dos alunos surdos potencializa de um modo particular a alfabetização cartográfica. No entanto, apesar de os processos de aquisição de conhecimentos cartográficos serem realizados de formas relativamente diferentes entre os alunos surdos e ouvintes, dadas as diferenças entre as modalidades sensoriais envolvidas em um e outro caso, parece-nos que uma vez constituídos pelos alunos os significados próprios à alfabetização cartográfica, a leitura dos mapas ocorre de um modo igualmente eficaz. Nesse sentido, identificamos na Cartografia um componente pedagógico profundamente democrático.

Assim, nas aulas de Geografia para alunos surdos e deficientes auditivos é relevante considerar a importância do aprendizado mediado pela comunicação visual em Libras e o uso de recursos didático-pedagógicos como ferramentas para a compreensão dos conteúdos. A Cartografia Escolar assume um papel comunicativo de destaque entre alunos e conteúdos, apresentando de forma aplicada o modo pelo qual algumas informações podem ser organizadas em um mapa ou outra representação cartográfica. 


\section{METODOLOGIA DA PESQUISA}

A Escola Estadual de Educação Especial Dr. Reinaldo Fernando Cóser localiza-se no Bairro Lorenzi (figura 1), na região sul do município de Santa Maria. É uma instituição de referência no atendimento a alunos surdos e deficientes auditivos. Segundo informações obtidas junto à $8^{\circ}$ Coordenadoria Regional de Educação $\left(8^{\circ} \mathrm{cre}\right)$, responsável pela administração das escolas estaduais da região central do Rio Grande do Sul, a escola Cóser Possuía 78 alunos matriculados no ano de 2017, sendo 34 (trinta e quatro) surdos e 44 (quarenta e quatro) deficientes auditivos, das mais variadas idades, tanto na Educação Infantil quanto na Educação de Jovens e Adultos (EJA).

Figura 1: Mapa de localização da Escola Cóser

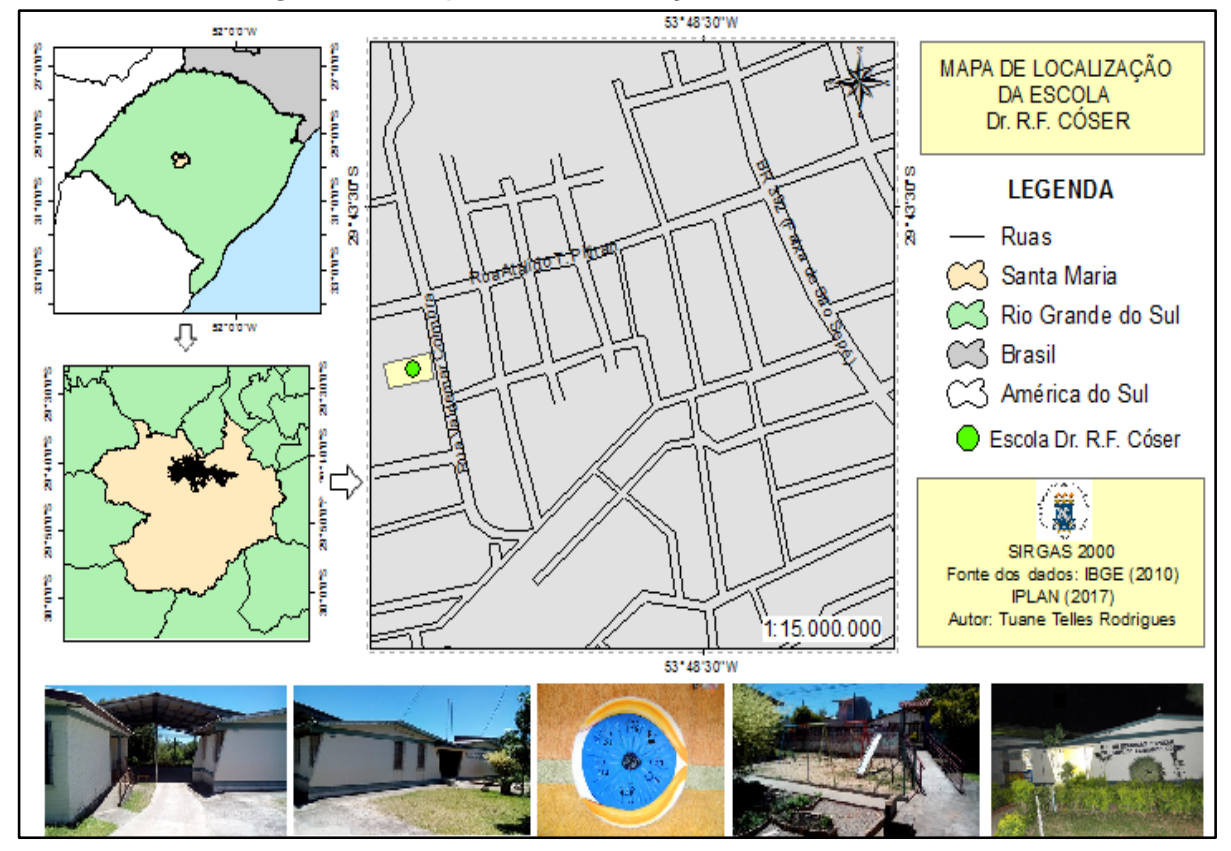

Fonte: Adaptado do IBGE (2010)

No mesmo período de coleta de dados, apenas uma outra escola do sistema estadual de ensino no município possuía um aluno surdo, a Escola Básica Estadual Cícero Barreto. Diante disso, é fácil imaginar a importância que a Escola Cóser possui para a comunidade surda da região, sendo esta a razão pela qual optamos em realizar a pesquisa na instituição. O local também atende alunos com outras necessidades especiais, como autismo, deficiência intelectual, entre outras, graças ao 
acompanhamento especializado disponibilizado. É possível também realizar lá cursos de Libras, que são oferecidos gratuitamente para toda a comunidade.

$\mathrm{Na}$ primeira etapa do trabalho, organizamos uma discussão teórica sobre metodologia do ensino de Geografia, o processo de alfabetização cartográfica e a aprendizagem de alunos surdos. Articulando estas três perspectivas, podemos compreender melhor como a Cartografia Escolar contribui para o ensino de Geografia voltado a alunos surdos, com o que compreendemos que o elo mais forte nesse processo, capaz de transcender a simples visualização de uma representação cartográfica e a análise de informações, é o diálogo entre a linguagem cartográfica e a língua brasileira de sinais.

A segunda etapa foi concebida a partir do contato com os alunos por meio de uma oficina de alfabetização cartográfica que objetivou introduzir noções de Cartografia e mostrar como é realizado o mapeamento de dados. Contando com 3 turmas do Ensino Fundamental, totalizando 12 alunos, sendo 5 do sexto ano, 2 do sétimo, e 5 do oitavo ano, as oficinas ocorreram ao longo de um mês, devido aos poucos encontros semanais (limitados a $90 \mathrm{~min}$. durante as aulas de Geografia). As atividades foram estruturadas em três momentos: no primeiro, apresentamos três mapas temáticos, um referente aos biomas brasileiros, outro sobre as atividades econômicas do país e o terceiro sobre a distribuição de renda (todos disponíveis no site do IBGE, na seção mapas), sendo solicitado que os alunos fizessem a leitura das representações e nos explicassem o que compreenderam, destacando as referências utilizadas para interpretar; no momento seguinte, realizamos a exposição teórica sobre os elementos que constituem os mapas, apresentando as noções de escala (gráfica e numérica), legenda e convenções cartográficas, orientação, coordenadas (UTM e geográficas), título e projeções; ao final das oficinas, levamos os alunos ao laboratório de informática para realizarem a atividade prática através do jogo digital "CartoCon: Nossa Expedição Geográfica". Em busca da qualificação da oficina pelos alunos, aplicamos um questionário relacionado a leitura e a interpretação dos alunos sobre os mapas temáticos apresentados, antes da exposição teórica dos conteúdos. Este instrumento de análise foi construído de forma simples e objetiva, para facilitar a compreensão dos alunos uma vez que muitos não dominavam amplamente a escrita da língua portuguesa. Embora as oficinas objetivam outras perspectivas de análise, como a introdução da Cartografia Escolar e a capacidade de mapeamento, cinco 
perguntas propostas no questionário possibilitaram compreender a relação que estamos discutindo. A seguir, apresentamos as questões utilizadas:

a) Você entendeu o tema dos mapas?

b) Você conseguiu descobrir qual território foi representado no mapa?

c) Você conseguiu compreender a distribuição das informações a partir do tema apresentado no mapa 2 (atividades econômicas)?

d) Qual a sua impressão ao observar o primeiro mapa (biomas do Brasil)?

e) Qual a sua conclusão ao observar o mapa 3 (distribuição da renda)?

Tendo o diálogo sido mediado pela professora da classe, as respostas dos alunos foram dadas em Libras, sem a necessidade de escrita em língua portuguesa (o que acarretaria dificuldades para muitos alunos em estágio de alfabetização). Nesses termos, os alunos conseguiram expressar melhor as respostas, bem como dialogar com os demais colegas de classe e apontar as características que chamaram atenção nos mapas.

\section{RESULTADOS E DISCUSSÃO}

O resultado da primeira etapa, a de selecionar o embasamento teórico com a finalidade de orientar a pesquisa, mostrou, além de reflexões sobre aspectos sociais, democráticos e subjetivos envolvidos no ensino de Geografia, na alfabetização cartográfica e na Educação Especial (com enfoque na aprendizagem de alunos surdos e deficientes auditivos), diferentes metodologias inclusivas para ensinar Geografia, artesanais ou digitais, baseadas em propostas alicerçadas na modernização das ferramentas de ensino. Pudemos também, com base nas leituras realizadas, inferir a existência de uma afinidade potencial entre a linguagem cartográfica e a língua brasileira de sinais, em razão da semiologia presente na estrutura da Libras e na dialogicidade da Cartografia Escolar. O segundo resultado obtido, referente às respostas dos alunos sobre a comunicação que os mapas possibilitaram, sugeriu a confirmação de que a forma de comunicação dos alunos surdos favorece a compreensão de informações cartográficas, e estas, simultaneamente, adequam-se ao seu processo peculiar de aprendizagem. É importante destacar que os sinais utilizados em Libras, como apontado por Rodrigues et al. (2018), não possuem uso unânime e pacificado no que se refere ao ensino de Geografia. Com isso, a 
comunidade surda em outros municípios, estados ou regiões pode utilizar formas diferentes de sinalização. Nesse sentido, detalharemos as respostas para melhor compreender tal relação:

a) Você entendeu o tema dos mapas? Nove alunos disseram compreender o tema dos mapas após a leitura do título, tendo maior dificuldade com algumas palavras em português, em relação às quais ainda não tinham um sinal de libras correspondente. Três alunos do sexto ano não compreenderam a informação pela carência de alfabetização em língua portuguesa. Acreditamos que o título de um mapa é onde tanto os alunos surdos como os ouvintes buscam a compreensão do tema de um mapa. Os alunos surdos, no entanto, parecem compreender a temática ainda que apenas olhem as informações apresentadas na legenda, entendendo como os dados se espacializam de forma diferente sobre o território.

b) Você conseguiu descobrir qual território foi representado no mapa? Todos os doze alunos identificaram-no corretamente, por ser um mapa de uso corriqueiro durante aulas de Geografia e apresentado regularmente nos livros didáticos. Solicitamos que os alunos nos mostrassem como representam o Brasil por meio da Libras, e o sinal utilizado envolveu a formação da letra $B$, com uma das mãos, e o seu deslizamento no sentido norte-sul, em frente ao rosto, exprimindo a característica vertical que o país possui. Nesse sentido, é possível observar semelhanças entre o território representado nos mapas e o sinal utilizado pelos alunos.

c) Você conseguiu compreender a distribuição das informações a partir do tema apresentado no mapa 2 (atividades econômicas)? Pudemos discutir com os alunos um pouco sobre a economia brasileira, a importação e exportação de produtos, diversificando dessa forma as informações que podem ser expressas nos mapas. Dos doze alunos, onze conseguiram realizar de forma satisfatória a interpretação do que foi apresentado, e destes todos os alunos do sétimo (dois discentes), todos do oitavo (totalizando cinco), e quatro alunos do sexto ano (composto por cinco alunos) entenderam a distribuição das informações. Apenas um dos alunos, que possui o transtorno do déficit de atenção e hiperatividade, relatou maior dificuldade com a leitura da legenda.

d) Qual a sua impressão ao observar o primeiro mapa (biomas do Brasil)? Essa questão buscou aproximar os alunos das questões ambientais que poderiam ser trabalhadas em outro momento pela professora, ao explorar temas em Educação 
Ambiental. Isso mostra aos alunos a diversificação de dados que a Cartografia pode espacializar, e como ela pode ser considerada uma ferramenta de ensino democrática. Todos os alunos participantes conseguiram entender a espacialidade dos biomas brasileiros. Com isso, pudemos discutir brevemente algumas noções de clima, geomorfologia, biogeografia e vegetação. Os alunos atentaram mais ao bioma Pampa, por ser encontrado no Rio Grande de Sul, e pelo apelo cultural que o bioma apresenta, sendo expresso em músicas, fotografias e outras manifestações.

e) Qual a sua conclusão ao observar o mapa 3 (distribuição da renda)? A questão buscou explorar, além da leitura e interpretação do mapa, a criticidade sobre a distribuição de renda no território nacional, sem exigir dos alunos conhecimentos complexos sobre os agentes envolvidos na disparidade de renda no Brasil. Os alunos então relacionaram o mapa a situações próprias à sua realidade, à escola, à comunidade. Apesar de tímidos, quatro alunos afirmaram entender que a distribuição de renda não ocorre de forma igualitária, e que com isso, são gerados difíceis problemas de acesso a serviços essenciais para uma vida de qualidade, e consequentemente, problemas sociais e vulnerabilidades.

Analisando os resultados obtidos por meio do questionário - aplicado ao final da aula expositiva - verificamos que os alunos conseguem entender os conteúdos pertinentes ao ensino de Geografia por meio da contextualização adequada que os mapas possibilitam, mostrando assim, que a Cartografia é um valioso instrumento para o ensino de Geografia no contexto da inclusão escolar.

Em suma, podemos considerar que a aplicação dos mapas temáticos como instrumento para o ensino de Geografia é uma ferramenta valiosa não apenas para alunos ouvintes, mas também para alunos surdos e deficientes auditivos. Isso ocorre graças às características da linguagem cartográfica e sua capacidade de interlocução com os discentes. A percepção dos alunos da Escola Cóser possibilitou-nos refletir sobre esse aspecto dialógico da Cartografia.

A abordagem pedagógica aqui pressuposta tenciona favorecer, com o intermédio das atividades cartográficas, a passagem de um aluno expectador da realidade para um sujeito ativamente construtor de conhecimentos. Com a compreensão do mapeamento e a espacialidade das informações, empoderam-se os sujeitos, instrumentalizando-os, até mesmo criticamente, para a vida em comunidade. Acreditamos que para a discussão sobre o papel da Geografia na inclusão escolar far- 
se-á necessário refletir sobre a epistemologia do pensamento geográfico e sua relação com a psicogênese do conhecimento na criança, tendo em vista a busca de novos métodos de ensino.

Ficou evidente, em nossa experiência, a existência de uma afinidade potencial entre a linguagem cartográfica e a língua brasileira de sinais, pois a construção de sinais e as análises das imagens reproduzidas nos mapas estiveram diretamente vinculadas aos sinais operados pelos alunos como forma de identificação e comunicação sobre os temas propostos. Os alunos compreenderam o significado das representações, a partir da comunicação não verbal, facilmente decifrada por eles, apesar de não dominarem todos os conceitos envolvidos na arte do mapeamento.

É possível e desejável examinar o potencial pedagógico da Cartografia em relação a alunos com outras necessidades especiais, como cegueira e baixa visão. Necessita-se, para isso, a continuidade das discussões sobre a Cartografia Escolar como ferramenta democratizadora e o ensino de Geografia como disciplina escolar com papel vanguardista na busca por estratégias de inclusão escolar.

\section{CONSIDERAÇÕES FINAIS}

Este artigo buscou compreender algumas relações entre a linguagem cartográfica e a língua brasileira de sinais, de modo a refletir sobre a capacidade inclusiva que o ensino de Geografia possui. Ficou claro que a alfabetização cartográfica tende a ser uma das etapas mais importantes nesse processo. Sua relevância está em sua natureza, as características que fazem da Cartografia uma linguagem capaz de ser apropriada - e transformada - por alunos com ou sem necessidades especiais. Com isso, a Cartografia Escolar pode ser, e de fato se torna, um apropriado veículo de comunicação entre a Geografia, os alunos e a sociedade.

A educação inclusiva deve considerar as transformações dos meios de comunicação e entretenimento e utilizar suas linguagens a seu favor. A comunicação é o locus central desse processo e o contexto de atuação privilegiada do educador. Nela devem operar os esforços de integração e valorização das diferentes experiências. Democratizar a educação é, assim, não apenas a introdução de um conceito político-liberal nos modos de gestão da instituição escolar. É torná-la 
efetivamente um espaço de convivência capaz não apenas de reproduzir, mas de alterar relações sociais.

A inclusão escolar é parte necessária de um tempo em que a sociedade toma consciência de que o aprendizado também está no convívio e na experiência, com o amadurecimento das teorias e técnicas de aprendizado. Nesse sentido, acreditamos que existem carências no modelo proposto para a educação que precisam urgentemente de atenção e soluções, exigindo ações que democratizam as mais variadas áreas do conhecimento e tragam os alunos às novas dinâmicas de um mundo informatizado. É preciso estimular a integração das teorias e modelos práticos com mediações contemporâneas, fazendo uso das tecnologias voltadas à educação.

Assumindo um papel importante na educação geográfica, a Cartografia inclusiva possibilita a mediação de uma diversidade de temas e conteúdos de interesse social aos educandos com necessidades especiais. Na medida em que as experiências fazem parte do cotidiano, vemos o aperfeiçoar de teorias e métodos na Geografia e em outras áreas do conhecimento. É importante para o sujeito compreender o espaço em que vive nas mais diferentes escalas. Neste sentido, devemos mostrar-lhe o mundo, utilizando e respeitando suas experiências e limites, sejam sensoriais ou cognitivos.

É direito do educando o acesso ao mundo espacializado, seja em um mapa, uma maquete ou na interface digital, assim como lhe é fundamental compreender as dinâmicas que o rodeiam, o que corresponde ao dever do professor de lhe mostrar o caminho, não apenas através de recursos simples, mas também ambientando-o no mundo técnico e informatizado em que vivemos, tornando-o independente e autônomo, consciente de seus direitos e deveres de cidadão.

A educação deve ser construída para todos. Parte desse investimento tem natureza político-governamental, a outra parte diz respeito à construção de propostas de ensino por parte da comunidade científica. A proposta da construção de sinais padronizados no uso de libras, a fim de facilitar a comunicação entre professores e alunos em qualquer lugar do território nacional, nasce do anseio por equidade nas práticas educativas, sem que com isso se abra mão das especificidades culturais e intelectuais. 


\section{REFERÊNCIAS}

ALMEIDA, R. D.; PASSINI, E. Y. O espaço geográfico: ensino e representação. São Paulo: editora Contexto, 1994. BACHELARD, G. Ensaio sobre o conhecimento aproximado. Rio de Janeiro: Contraponto, 2004.

CASTROGIOVANNI, A. C.; GOULART, L. B. A questão do Livro didático em geografia: elementos para uma análise. In: CASTROGIOVANNI, A. C. Geografia em sala de aula: práticas e reflexões. 2. ed. Porto Alegre: Universidade Federal do Rio Grande do Sul, 1998. p. $129-132$.

CASTELLAR, S. Educação Geográfica: A psicogenética e o conhecimento escolar. Campinas: cadernos CEDES, p. 209-22, 2005.

CALLAI, J. L. Área dos estudos sociais: metodologia. ljuí: UNIJUì, 1986.

CAVALCANTI, L. de S. Cotidiano, mediação pedagógica e formação de conceitos: uma contribuição de Vygotsky ao ensino de Geografia. Caderno CEDES: Campinas v. 25 n. 66,2005

DOMINGUES, J. M. P. A facilitação da leitura de mundo e de textos escritos através da contação de histórias e de obras de arte. In: Fórum-Instituto Nacional de Educação de Surdos. v. 14, (jul/dez), Rio de Janeiro: INES, 2006.

FERNANDES, E.; CORREIA, C. M. de C. Bilinguismo e surdez: a evolução dos conceitos no domínio da linguagem. In: FERNANDES, E. Surdez e Bilinguismo. Porto Alegre: editora Mediação, 2010.

FRANCISCHETT, M. N. A cartografia como um sistema de signos. Francisco Beltrão: Revista Faz Ciência, 1997. FRAWLEY, W. Vygostsky y la ciencia cognitiva. Barcelona: Paidós, 1999.

LIMA, S. T. Análise crítica das representações cartográficas nos livros didáticos de $1^{\circ}$ e $2^{\circ}$ Graus. São Paulo: Boletim Paulista de Geografia, n. 70, 1992.

PIERCE, C. S. Semiótica. 3 ed.São Paulo: editora Perspectiva, 2005.

RODRIGUES, T. T. A cartografia inclusiva e o futuro no ensino da Geografia. In: VII Congresso Internacional de Educação. Santa Maria, 2017. Anais Faculdade Palotina de Santa Maria, p. $1-8$.

RODRIGUES, T. T.; KEPPEL, M. F.; MIRANDA, W. de O. A Língua brasileira de sinais e os desafios no ensino de Geografia. Revista Geographia Meridionalis: Pelotas. v. 4, n. 2, jul.-dez. 2018, p. 185-205.

SANTAELLA, L. O que é semiótica. São Paulo: Brasiliense, 1983.

SANTANA, A. P. Surdez e linguagem: aspectos e implicações neolinguísticas. São Paulo: editora Plexus, 2007.

SASSAKI, R. K. Inclusão: construindo uma sociedade para todos. Rio de Janeiro: WVA, 1997.

SIRGADO, A. P. O conceito de mediação semiótica em Vygotsky e seu papel na explicação do psiquismo humano. In: Pensamento e Linguagem: estudos na perspectiva da psicologia soviética. Cadernos CEDES, n. 24, 3ed., Campinas, p. 38-51, 1991. 
SOUZA, J. G. de; KATUTA, A. M. Geografia e conhecimentos cartográficos: a cartografia no movimento de renovação da geografia brasileira e a importância do uso de mapas. São Paulo: Editora UNESP, 2001. 


\section{CAPÍTULO 17}

TECNOLOGIA ASSISTIVA (T.A): ALGUNS APONTAMENTOS

\section{André Haiske}

Universidade Federal de Santa Maria

Perfil: http://lattes.cnpq.br/6615631028920827

E-mail: andrehaiske@gmail.com

\section{Leonice Aparecida De Fátima Alves Pereira Mourad}

Universidade Federal de Santa Maria

Perfil: http://lattes.cnpq.br/7689442989367017

E-mail: profleomourad@gmail.com

\section{Maria Carolina Magalhães Santos}

Cooperativa de Trabalho Educacional Dom Hermeto

Perfil: http://lattes.cnpq.br/1215930938979505

E-mail: mariacarolina1819@gmail.com

Resumo: O presente artigo de revisão bibliográfica teve como objetivo apresentar, sumariamente, a temática da denominada Tecnologia Assistiva (T.A.). Está entendida como um conjunto de itens e assistentes tecnológicos, que facilitam a vivência cotidiana de pessoas com algum tipo de deficiência, promovendo assim, uma melhor qualidade de vida e bem-estar, em prol da inclusão e projetando a autonomia do sujeito. Contudo, essa literatura especializada evidencia a importância de um elemento fundamental, frente a viabilização de processos inclusivos educacionais.

Palavras-chave: Inclusão; Habilidades; Técnicas; Tecnologia Assistiva. 


\section{DEFINIÇÃO E ORIGENS}

O termo ainda novo, Tecnologia Assistiva (T.A.) é definida como uma área do conhecimento de característica interdisciplinar, que engloba produtos, recursos, metodologias, estratégias, práticas e serviços, sendo estes recursos e serviços utilizados para contribuírem ou ampliar habilidades funcionais de pessoas com deficiência e consequentemente promover vida independente e inclusiva (SARTORETTO; BERSCH, 2021).

A Tecnologia Assistiva é "Qualquer item, peça de equipamento ou sistemas de produtos, quando adquiridos comercialmente, modificados, ou feito sob medida, que é usado para aumentar, manter ou melhorar as habilidades funcionais do indivíduo com limitações funcionais" (Technology-Related Assistance for Individuals with Disabilities Act - Public 100-407) lei municipal E.U.A. de 1998.

Nesta percepção, a:

Tecnologia Assistiva é uma expressão nova, que se refere a um conceito ainda em pleno processo de construção e sistematização. A utilização de recursos de Tecnologia Assistiva, entretanto, remonta aos primórdios da história da humanidade ou até mesmo da pré-história. Qualquer pedaço de pau utilizado como uma bengala improvisada, por exemplo, caracteriza o uso de um recurso de Tecnologia Assistiva. (GALVÃO; FILHO, 2009).

De acordo com a definição estabelecida no Brasil pelo Comitê de Ajudas Técnicas (CAT), expedida pela Secretaria Especial dos Direitos Humanos da Presidência da República, elucida-se:

Tecnologia Assistiva é uma área do conhecimento, de característica interdisciplinar, que engloba produtos, recursos, metodologias, estratégias, práticas e serviços que objetivam promover a funcionalidade, relacionada à atividade e participação, de pessoas com deficiência, incapacidades ou mobilidade reduzida, visando sua autonomia, independência, qualidade de vida e inclusão social. (BRASIL, 2009, p. 9)

A T.A. apresenta como objetivos melhorar a forma de comunicação, locomoção e aprendizado, possibilitando à pessoa com deficiência uma maior dependência, maior qualidade de vida e assim uma inclusão sociocultural, por meio da ampliação de sua comunicação, mobilidade, controle e integração com seu ambiente, trabalho e integração com a família, amigos e sociedade (SARTORETTO; BERSCH, 2021).

A A.T pode ser divida em dois componentes, de acordo com a legislação nos Estados Unidos, recursos e serviços, "os recursos são todo e qualquer item, equipamento ou parte dele, produto ou sistema fabricado em série ou sob-medida 
utilizado para aumentar, manter ou melhorar as capacidades funcionais das pessoas com deficiência. Serviços são definidos como aqueles que auxiliam diretamente uma pessoa com deficiência a selecionar, comprar ou usar os recursos acima definidos" (ADA - AMERICAN WITH DISABILITIES ACT, 1994; BERSCHE; TONOLLI, 2006).

Embora ao refletirmos sobre a T.A., podemos cair no engano de situar a mesma somente em momentos de grandes avanços tecnológicos da contemporaneidade, ela é muito mais antiga. Manzini (2005), cita por exemplo, que uma bengala é uma tecnologia assistiva, como um aparelho de surdez. Ambos, à sua maneira, produzem uma melhor autonomia e qualidade de vida para o usuário.

As primeiras discussões sobre a T.A., surgiu nos Estados Unidos, no contexto da Assistive Technology, que surgiu a partir de 1988 no contexto da Public Law 100407, em um conjunto de leis e argumentos jurídico que ( $A D A$ - American with Disabilities $A c t)$, que entre tantas coisas, regula direitos das pessoas portadoras com deficiência e o uso e distribuição de recursos públicos para a melhoria da qualidade de vida destas pessoas. Tal ato ainda foi renovado no país, com a Assistive Technology Act de 1998 (P.L. 105-394, S.2432).

Além de suas variações em outros continentes, como na Europa e em outros países, no Brasil as discussões em âmbito de política nacional ocorreram a partir de 2006 dentro da pasta da Secretaria Especial dos Direitos Humanos da Presidência da República (SEDH/PR), através da portaria no 142 . Com a instituição do Comitê de Ajudas Técnicas (CAT), que tinham como objetivo organizar parcerias público-privada em relação das T.A. e estimular políticas e estratégicas de implementação e auxílio em diversos níveis da esfera pública, bem como incentivar pesquisas e qualificação na área (BRASIL - SDHPR, 2012).

Em 14 de dezembro de 2007, foi aprovada o T.A brasileiro sendo conceituado como:

\footnotetext{
uma área do conhecimento, de característica interdisciplinar, que engloba produtos, recursos, metodologias, estratégias, práticas e serviços que objetivam promover a funcionalidade, relacionada à atividade e participação, de pessoas com deficiência, incapacidades ou mobilidade reduzida, visando sua autonomia, independência, qualidade de vida e inclusão social (BRASIL - SDHPR, 2009).
}

A partir disso, pode-se perceber um aumento e maior exploração na realização de pesquisas teóricas ou em aplicações práticas, agregando um domínio multidisciplinar. fazendo parte engenheiros de reabilitação, de computação, e 
elétricos, biomédicos; arquitetos, médicos, fisioterapeutas, terapeutas ocupacionais, fonoaudiólogos, desenhistas industriais, analistas de sistemas, educadores, entre outros. Um excelente exemplo de trabalho multidisciplinar, foi na Copa do Mundo de 2014 no Brasil, quando um sujeito paraplégico conseguiu "chutar" a bola por meio de um exoesqueleto, utilizando a T.A como ferramenta de inclusão e um grupo interdisciplinar com diversos profissionais envolvidos (SARTORETTO; BERSCH, 2021). Portanto, a introdução e a utilização das T.A. requere estudos de caso, acompanhamento de diversos profissionais, do corpo médico ao receitar o uso de uma T.A. ao produto final, confeccionado especialmente para aquela pessoa, que necessita de seu uso para adquirir uma vida mais autônoma e saudável

\begin{abstract}
As pesquisas enfatizaram a necessidade do envolvimento de profissionais especializados em diferentes áreas do conhecimento para o trabalho com pessoas com deficiência para atender as diferentes etapas dos serviços da tecnologia assistida: avaliação e identificação das habilidades e necessidades; prescrição e confecção dos recursos; acompanhamento, bem como perceber necessidades de modificações destes recursos durante a sua utilização (ROCHA; DELIBERATO, 2012, p. 2).
\end{abstract}

\title{
2. OS TIPOS DE TECNOLOGIA ASSISTIVA
}

Existem vários tipos e utilizações de T.A. com intuito de facilitar a vida no ambiente doméstico, no trabalho, lazer e no educacional, sendo este último o foco neste presente artigo. Segundo, Sartoretto e Bersch (2020) abordam 11 categorias, com suas discussões deste 1998 e até a atualidade, a partir das noções da já citada $A D A$. Essas categorias não estão presas apenas a um tipo de função, mas perpassam diversos ambientes e situações no âmbito educacional.

Entre as 11 categorias destacam-se auxílios para a vida diária, como auxílio em tarefas rotineiras, tais como: comer, cozinhar, vestir-se, tomar banho e executar necessidades pessoais. A comunicação também faz parte nestas categorias com recursos eletrônicos ou não, os quais permitem a comunicação, expressão e receptiva das pessoas, com limitações da fala ou sem a mesma. Sendo muito utilizadas as placas ou pranchas de comunicação, com os símbolos PCS ou Bliss, além de vocalizadores e softwares dedicados para este fim. Além do mais, recursos de acessibilidade ao computador, sistemas de controle de ambiente, projetos arquitetônicos para acessibilidade, órteses e próteses, adequação postural, auxílios de mobilidade, auxílios para cegos ou com visão subnormal, auxílios para surdos ou 
com déficit auditivo e adaptações em veículos também são importantes ferramentas para utilizações T.A. (SARTORETTO; BERSCH, 2021).

Ao refletir sobre 0 ambiente escolar, primeiramente deve-se haver uma adaptação para receber o estudante, porque este acolhimento gera segurança e esta possibilita a inclusão educacional. Em relação à parte estrutural, a escola necessita propor e participar de solicitações de projetos arquitetônicos para a acessibilidade, tais como rampas, elevadores, adaptações em portas, banheiros e classes e outras estruturas para abordar todas as necessidades especiais (MANZINI,2005)

A adequação postural também é importante, pois viabiliza conforto físico, através de classes e/ou outros materiais, os quais serão usufruídos pelos alunos, permitindo confortabilidade e segurança, no transporte do aluno, além de outras adaptações, em veículos como vans, carros ou ônibus, que também estarão atrelados ao ambiente escolar, por facilitar o acesso até a escola (GALVÃO FILHO, 2009.

Geralmente, a adaptação no espaço escolar apresenta desafios da educação na atualidade, uma simples adaptação da infraestrutura, como móveis e objetos podem ser facilmente substituídos para garantir mais acessibilidade e inclusão. Mas, e a parte humana da escola? O corpo de professores, funcionários gerais e administrativos devem ter um olhar, conectado com as demandas e desafios propostos em nossa sociedade (

$\mathrm{Na}$ percepção de Freire e Cirini (2016), o seu uso na escola no contexto educacional, necessita-se de "criatividade e disposição para encontrar alternativas adequadas a cada situação, não basta o recurso, é preciso planejamento e, nesse caso, articulação com o conteúdo a ser ensinado." (ibid, p. 05). Desta forma, torna-se fundamental a integração das tecnologias digitais não somente no setor administrativo da escola ou na sala de informática, mas também dentro da sala de aula. Vale ressaltar que na maioria das vezes, as crianças antes de ter contato com o mundo escolar, já tem contato com diversas formas de tecnologias. Deste modo, o papel do educador na escola, vai além da informação e sim no direcionamento de ensinar o que informar, sem ignorar o conhecimento prévio que os alunos trazem de casa (SARTORETTO; BERSCH, 2021).

[...] O educador continua sendo importante, não como informador nem como papagaio repetidor de informações prontas, mas como mediador e organizador de processos. O professor é um pesquisador - junto com os alunos - e articulador de aprendizagens ativas, um conselheiro de pessoas 
diferentes, um avaliador dos resultados. O papel dele é mais nobre, menos repetitivo e mais criativo do que na escola convencional. (MORAN, 2009, p.103).

Portanto, o papel do educador, como mediador, vincula a troca de ideias, de conhecimentos e discussões. Este mediará todo o conhecimento e vivência que os alunos trazem de casa para o ambiente escolar, e com isso, produzir algo mais forte, próximo e significativo para o aluno. Além de mediadores, os educadores são como orientadores, no sentido emocional, intelectual e ético. Com apoio, incentivo e direcionamento irão auxiliar no crescimento intelectuais, na forma de disciplinas e na vivência como ser humano em uma comunidade coletiva e diversa como a escola (CIRINO; BATISTA, 2016)..

\begin{abstract}
O uso da tecnologia assistiva na escola demanda não somente o recurso, mas também um serviço que ofereça estratégias para o seu uso. As estratégias devem ter início anteriormente à prescrição ou construção do recurso, ou seja, é necessário observar a dinâmica do estudante no ambiente escolar e reconhecer suas necessidades. Por meio das informações do aluno, dos profissionais da escola e do ambiente é possível estabelecer critérios para elaborar recursos com perspectivas funcionais que atendam às necessidades específicas do aluno com deficiência e consequentemente diminua as taxas de abandono dos recursos de tecnologia assistiva (ROCHA; DELIBERATO, 2012, p. 2-3).
\end{abstract}

Será que os professores, como educadores e mediadores, estão preparados para receber alunos que necessitarão do uso das T.A.? E o corpo administrativo está preparado? A escola possui profissionais de Atendimento Educacional Especializado (AEE) para auxiliar e monitores?

A formação do professor, se este está apto e confortável em utilizar estas ferramentas em sala de aula. Por isso,

[...] é importante que o professor avalie os instrumentos e/ou recursos, tecnológicos ou não, que possa utilizar, observando o resultado que tais instrumentos e/ou recursos têm ocasionado na aprendizagem dos alunos, redirecionando sua prática caso necessário. Para tanto, é fundamental que o professor saiba como utilizar as tecnologias na escola, fato que, talvez, aponte a necessidade de formação dos professores nessa área (ibid, p.6).

Nesse contexto, pode ser necessário realizar aos poucos essas ferramentas e acessibilidades digitais e tecnológicas na sala de aula, utilizando do mais simples ao mais complexo, utilizando por exemplo, vídeos mais curtos e chamativos num primeiro momento e avançando até vídeos mais complexos do mesmo tema (TRABUCO; GONÇALVES; PICOLI, 2018).

$\mathrm{Na}$ escola, as T.A. estão no universo das Tecnologias da Informação e Comunicação, ou TICs. As TICs, "estão presentes na vida dos alunos, na sociedade, 
e no meio educacional não podem ser desconsideradas" (SILVA; PICOLLI, 2018, p.4). Aqui não é importante somente adicionar essas tecnologias, mas saber como aplicálas para não ficar repetitivas ou simplesmente mecânicas.

Por outro lado, em tempos de pandemia, o uso de ferramentas digitais para o ensino aumentou em grande proporção. Essas ferramentas de acesso e plataforma online, utilização de vídeo-aulas, gravação de materiais didáticos e inúmeras outras que vêm surgindo a contribuindo para o ensino, resultando em estimular e acelerar o uso de ferramentas digitais ao ensino auxiliando no processo de ensino-aprendizagem (SARTORETTO; BERSCH, 2021). Com isso, o ensino busca ferramentas para suas aulas, síncronas e assíncronas, as quais conectam todos em qualquer lugar, sendo no âmbito escolar como em domicílio. Esse sistema de ensino híbrido, inicialmente, assustou muitos professores e instituições nas primeiras semanas de fechamentos de escolas, tendo demandado uma rápida incorporação de tecnologias na rotina pedagógica da relação ensino-aprendizagem. Porém, aprende-se melhor, quando se vivencia e implementa novas experiências, descobrindo novos significados, antes despercebidos. Assim, estabelecendo conexões entre a reflexão e a ação, entre a experiência e a conceituação, entre a teoria e a prática, enquanto uma completa a outra.

\section{CONSIDERAÇÕES FINAIS}

Um dos grandes desafios da educação na atualidade é contribuir de tal sorte a fazer com que a informação se torne significativa, selecionando aquelas que são efetivamente relevantes, de tal forma a compreendê-las de forma cada vez mais abrangente e profunda. $\mathrm{O}$ docente é um pesquisador em permanente aprendizagem, ele aprende com a pesquisa com a prática e ensina a partir do que aprende. $\mathrm{O}$ seu papel é fundamentalmente o de um orientador/ mediador, sendo responsável pela integração de tecnologia, metodologias e atividades; integração de textos escritos, comunicação oral, hipertextual, multimídia; aproximação da mídia e das atividades para que haja um fácil trânsito de um meio ao outro; trazer o universo do audiovisual para dentro da escola, diversificação no modo de ministrar aulas e no processo de avaliação; valorização da presença e a comunicação virtual e equilibrar a presença e

a distância. É de suma importância que o educador seja capaz de integrar todas as 
tecnologias: as telemáticas, as audiovisuais, lúdicas, as textuais, musicais. De tal modo, que as T.A., principais recursos que potencializam efeitos de inclusão, com efetivas ações capazes de garantir dignidade do sujeito como ser humano, obtendo seus direitos ao acesso democrático e estimulante, facilitando assim, o pleno desenvolvimento humano.

Com isso, o uso da tecnologia assistiva na educação é de fundamental importância, pois possibilita pleno desenvolvimento do processo de aprendizagem, otimizando as potencialidades de cada aluno com base nas suas especificidades. Esses recursos de T.A acabam servindo de empoderamento para a mobilidade, atividades relacionadas à aprendizagem, trabalho, comunicação e interação com o mundo decorrendo daí sua importância nos dias atuais, uma vez que os mesmo podem garantir a efetividade da acessibilidade e da inclusão. 


\section{REFERÊNCIAS}

ADA - American With Disabilities, ACT 1994. Disponível em: https://adata.org/ Acesso em: $14 / 07 / 2021$.

BRASIL. Secretaria Especial dos Direitos Humanos. Subsecretaria Nacional de Promoção dos Direitos da Pessoa com Deficiência. Comitê de Ajudas Técnicas. Tecnologia Assistiva. Brasília: CORDE, 2009a. Disponível em: http://www.pessoacomdeficiencia.gov.br/app/sites/ default/files/publicacoes/livro-tecnologia-assistiva.pdf . Acesso em: 11/032021.

BRASIL. SDHPR - Secretaria Nacional de Promoção dos Direitos da Pessoa com Deficiência - SNPD. 2009. Disponível em: http://www.pessoacomdeficiencia.gov.br/app/publi cacoes/tecnologia-assistiva Acesso em: 22/03/2021.

BRASIL. SDHPR - Secretaria Nacional de Promoção dos Direitos da Pessoa com Deficiência - SNPD. 2012 Disponível em: http://www.pessoacomdeficiencia.gov.br/app/ Acesso em: 22 fev.2021.

Subsecretaria Nacional de Promoção dos Direitos da Pessoa com Deficiência. Comitê de Ajudas Técnicas. Tecnologia Assistiva. Brasília: CORDE, 2009.

CIRINO, I.; BATISTA, R. As Tecnologias Assitivas no Contexto Escolar Freire. Disponível em:http://www.diaadiaeducacao.pr.gov.br/portals/cadernospde/pdebusca/producoes_pde/20 16/2016_artigo_edespecial_unespar-paranagua_ivonetefreire.pdf. Acesso em: 16/06/2021.

GALVÃO FILHO, T. A. A Tecnologia Assistiva: de que se trata? In: MACHADO, G. J. C.; SOBRAL, M. N. (Orgs.). Conexões: educação, comunicação, inclusão e interculturalidade. 1 ed. Porto Alegre: Redes Editora, p. 207-235, 2009. Disponível em: www.galvaofilho.net/assistiva.pdf. Acesso em: 26/07/2021.

KASSAR, M. C. M. Percursos da constituição de uma política brasileira de Educação Especial inclusiva. Revista Brasileira de Educação Especial, Marília-SP, v. 17, n. Especial 1, p. 41-58, maio/ago. 2011.

MANZINI, E. J. Tecnologia assistiva para educação: recursos pedagógicos adaptados. In: Ensaios pedagógicos: construindo escolas inclusivas. Brasília: SEESP/MEC, p. 82-86, 2005.

MORAN, J. M. A educação que desejamos: novos desafios e como chegar lá. 4ª ed. Campinas: Papirus, 2009.

SILVA, R. T. M.; GONÇALVES, F. D.; PICOLI, D. O Professor, a Mediação e as Tecnologias da Informação a da Comunicação no Processo de Ensino E Aprendizagem. CIET:EnPED, São Carlos, maio 2018. ISSN 23168722.Disponívelem:https://cietenped.ufscar.br/submissao /index.php/2018/article/view/446. Acesso em: 15 mar. 2021.

ROCHA, A. N. D. C.; DELIBERATO, D. Tecnologia assistiva para a criança com paralisia cerebral na escola: identificação das necessidades. Rev. bras. educ. espec. Marília , v. 18, n. 1 p. 71 92, Mar. 2012 . Disponível em:http://www.scielo.br/scielo.php?script=sci_ arttext\&pid=S1413-65382012000100006\&lng=en\&nrm=iso. Acesso em: 16/03/2021.

SARTORETTO, M. L.; BERSCH, R. O que é Tecnologia Assistiva?: Tecnologia e Educação, 2021. Disponível em: https://www.assistiva.com.br/tassistiva.html. Acesso em: 06/07/2021. 
WARSCHAUER, M. Tecnologia e inclusão social: a exclusão digital em debate. São Paulo: Editora Senac, 2006. 


\section{CAPÍTULO 18}

ENSINO DE HISTÓRIA PARA SURDOS: PROPOSTAS E DESAFIOS NA EDUCAÇÃO ESPECIAL

Laionel Mattos da Silva

Universidade Federal de Santa Maria

Perfil: http://lattes.cnpq.br/9565893372551639

E-mail: another.laio@gmail.com

\section{Leonice Aparecida de Fátima Alves Pereira Mourad}

Universidade Federal de Santa Maria

Perfil: http://lattes.cnpq.br/7689442989367017

E-mail: profleomourad@gmail.com

Resumo: A proposta do trabalho é debater o ensino de história para surdos através de um recorte espacial ligado à história regional, mais precisamente sobre o Massacre de Porongos, ocorrido durante a Guerra dos Farrapos (1835 - 1845). O ensino de história para os surdos é um tema recente nas pesquisas acadêmicas, por isso elegemos esse estímulo para a construção dessa investigação pelo interior de um tema regional ligado ao estado do Rio Grande do Sul. Discutiremos sobre o processo de ensino e aprendizagem dos alunos surdos de uma escola especial através de um jogo analógico didático bilíngue - com ênfase na cultura surda, mas destacando a possibilidade de um passatempo como aprendizagem para os alunos ouvintes também. Desse modo a construção do jogo versará sobre o Massacre de Porongos, com o objetivo de trazer as informações sobre esse evento, mas também, como forma de oportunizar a possibilidade de ressignificar a compreensão dessa história por meio de um jogo didático bilíngue.

Palavras-chave: Ensino da História; Educação de surdos; Educação especial; Jogos no ensino de história; História regional. 


\section{INTRODUÇÃO}

A história da educação de surdos no Brasil tem início quando, conforme dados históricos, D. Pedro II, durante o Brasil Império, oficializa uma instituição voltada para a educação da comunidade surda. Entretanto, é importante ressaltar que, segundo Strobel (2008), o povo surdo existe desde os primórdios da humanidade. Por isso, a comunidade surda brasileira sempre existiu, inclusive durante o período anterior à criação do Instituto educacional de surdos. O seu desconhecimento se dá pela segregação acometida a eles, o que os invisibiliza em nossa linha histórica, pois eram associados a aberrações. "O processo educacional dos surdos apresenta as diversas faces de uma educação excludente, desde que estes deveriam ser obrigados a falar e suas especificidades negadas." (Alves et al, 2015, p.30)

Acredito que o tema deste trabalho - o Ensino de História para surdos - é de relevância social e para o campo educacional. No campo social, visualizamos anos de ostracismo e naturalização de práticas segregadoras em relação à comunidade surda. Nesse mesmo sentido, mas no aspecto educacional, a educação de surdos ainda é deficitária em todas as modalidades de ensino do país, entretanto, é ainda mais falho no âmbito da educação básica, não se esquecendo do ensino superior que é a esfera formadora dos nossos profissionais no Brasil.

A partir deste cenário, temos como proposta de pesquisa o Ensino de História para surdos, buscando através de um recorte espacial, no caso a história regional, a elaboração de um jogo didático bilíngue, entende-se a língua de sinais (Libras) e a língua portuguesa. Na prática, iremos elaborar um jogo didático, usando como tema do desafio um recorte da História do Rio Grande do Sul, mais precisamente o Massacre de Porongos, durante a Guerra dos Farrapos (1835 - 1845).

Em uma geração que nasceu em meio às novas tecnologias, o uso do jogo analógico deve gerar algumas dúvidas, entretanto, nossa experiência em sala de aula evidencia que o jogo didático na versão tabuleiro ainda tem grande apelo no espaço escolar. O jogo é uma atividade que perpassa diversas gerações; é em torno dele que se reúnem familiares, amigos e simpatizantes de uma boa partida, pois de acordo com

A pesquisa foi realizada na Escola Estadual Especial de Ensino Fundamental Keli Meise Machado, que está situada na cidade de Novo Hamburgo. O jogo será destinado aos alunos do sexto, sétimo, oitavo e nono ano do ensino fundamental Cabe 
salientar, que propomos esse trabalho buscando compreender como ensinar história na Língua Brasileira de Sinais (Libras), mas a partir do bilinguismo. Neste sentido, entendemos como fundamental o respeito à cultura surda, sobretudo no que tange à sua língua, a Língua Brasileira de Sinais

Esse artigo é produto de uma defesa de uma pesquisa de mestrado. A proposta do artigo é debater o ensino de história para surdos, mais precisamente por meio de um recurso pedagógico e de entretenimento que o é jogo, salientando que esse recurso será analógico, didático e bilíngue.

\section{ENSINO DE HISTÓRIA}

O ensino de História vem se constituindo progressivamente como um campo de pesquisa no Brasil, portanto, tem sido agente de grande relevância entre a academia e a educação básica. (MONTEIRO, 2003). É importante lembrar que o tema é bem próximo à prática docente do Professor na educação básica, não que os demais não sejam, mas por se tratar especificamente do ensino e aprendizagem de história é que conseguimos observar a sua aproximação.

Por isso, buscaremos identificar, descrever e problematizar, através de autores do campo, o ensino de história, juntamente com a perspectiva da História escolar. Bittencourt (2004, p. 60) destaca que "O ensino de História sempre esteve presente nas escolas elementares ou escolas primárias brasileiras, variando, no entanto, de importância no período que vai do século XIX ao atual". Portanto, compomos a ideia de que a História escolar sempre fora de interesse dos governantes, cada um a sua época, reforçando a sua preocupação e, principalmente, com a construção de uma identidade nacional.

Dando seguimento a tal raciocínio, o ensino de história nacional parece ultrapassado, visto que na era da mundialização, ou seja, novas perspectivas mundiais no campo da história façam com que ele caia no esquecimento, entretanto, não podemos preterir o conhecimento sobre "as coisas e as gentes brasileiras".

A historiadora e educadora Ana Maria Monteiro (2007) em sua obra Professores de História - Entre Saberes e Práticas, no qual estuda o papel do Professor na sociedade contemporânea como intermediário na idealização dos saberes escolares, espraiando esse campo que é tão rico. Do mesmo modo, e não 
menos relevante, ela também valoriza o trabalho do Professor, que em tempos tão sombrios fica cada vez mais necessário essa reafirmação do saber.

Assim, os professores de história são fundamentais no processo de ensino e aprendizagem da história, na constituição dos saberes edificados no espaço escolar como também fora da Escola. A partir disso, entende-se que "com saberes que nela são produzidos e circulam, e onde os professores desempenham um papel estratégico" (MONTEIRO, 2007, p. 227), ou seja, que os educadores são fundamentais nesse processo do saber escolar - dentro da referência que the cabe.

Portanto, a investigação da prática docente no quesito educacional, mas, ligada ao campo do ensino de história, nos diz

\begin{abstract}
A partir dessa perspectiva recente no campo da pesquisa educacional, a escola passa a ser identificada como um espaço onde se constroem saberes próprios e que possui uma cultura escolar ao mesmo tempo em que esta cultura também faz da escola um ambiente vivo. Os sujeitos do processo educativo - estudantes e, no caso específico deste trabalho, docentes - não são apenas reprodutores, mas também criadores. (CUNHA; LIMA, 2017, p. 235).
\end{abstract}

É nesse entendimento do espaço escolar e com esses atores, alunas e professoras, que acredito que o ensino de história possa adentrar. É importante deixar cristalino que o nosso projeto falará sobre o ensino de história para surdas, em vista disso, mais adiante versaremos sobre esse conceito associadamente.

Diante disso, o ensino e aprendizagem de história são entendimentos distintos, visto que a aprendizagem lida com a assimilação do aluno sobre o conhecimento histórico e o ensino de história é mais direcionado à prática da formação docente. Todavia, entendemos que ambos atuam paralelamente.

\footnotetext{
É comum a afirmação de que o ensino e a aprendizagem de História acontecem por intermédio do domínio de conceitos, de modo que não basta, evidentemente, o aluno saber os nomes de pessoas famosas ou fatos ocorridos em determinados tempo e espaço que podem ser comprovados pelos documentos. (BITTENCOURT, 2004, p. 183).
}

Assim, o lugar de fronteira que Monteiro (2002) apresenta em sua obra, esse lugar de construção e de transmissão de saberes, ou seja, a geração de saberes a partir de conversas, de permutas e da recognição das diferenças. Por isso, compreendemos que a aprendizagem e o ensino de história devem constituir, no espaço escolar ou fora dele, o saber. 


\title{
2.1 Jogos no Ensino de História
}

O contexto escolar vem sentindo com urgência a necessidade de superar o modelo tradicional de ensino e as suas estruturas ultrapassadas esse sistema indiferente com a diversidade. Urge a busca por um ambiente escolar que trabalhe por aprendizagens mais significativas através do uso de métodos de ensino pertinentes aos novos discursos e técnicas. Neste caso, o ensino de história não pode ser apenas uma prática de leitura e cópia. É preciso ampliar as técnicas junto ao ensino para que tenhamos uma aprendizagem relevante.

À vista disso, a discussão sobre o uso do jogo no ensino de História é pertinente. Buscando romper com práticas ultrapassadas, o jogo ainda é um recurso recente na educação básica, mas que vem tomando força nos últimos anos. Para entendermos mais a sua significativa importância, Huizinga nos argumenta,

\begin{abstract}
A função do jogo (...) pode de maneira geral ser definida pelos dois aspectos fundamentais que nele encontramos: uma luta por alguma coisa ou a representação de alguma coisa. Essas duas funções podem também por vezes confundir-se, de tal modo que o jogo passe a 'representar' uma luta, ou se torne uma luta para melhor representação de alguma coisa. (2000, p. 14).
\end{abstract}

Por meio do processo lúdico, perseguiremos a construção do conhecimento histórico na Escola. Logo, o ensino de história através do jogo, exige um planejamento. O jogo deve ser uma via de estabilidade. O momento de brincar e o de seriedade, tal equilíbrio é necessário para o bom andamento do jogo. Creio que sem essa harmonia, não conseguiríamos atingir os objetivos pedagógicos propostos. (GIACOMONI, 2013)

Os autores, Giacomoni e Mullet, apresentam a seguinte afirmação:

[...] que brincar é aprender. Mais do que ser um instrumento de aprendizagem, a brincadeira é aprendizagem propriamente dita: ela não apenas contribui para a construção das estruturas do conhecimento, ou, eventualmente, leva à aprendizagem de conteúdos específicos; ela ;e, ela mesma, aprendizagem, porque a ação é o que a define, e a ação é a unidade mínima tanto do desenvolvimento, quando da aprendizagem. (2013, p. 79).

Diante de todos esses benefícios que o uso do jogo nos apresenta, é que idealizamos a proposta da nossa pesquisa. Um jogo analógico bilíngue como recurso pedagógico, para auxiliar professores e alunos surdos no processo de aprendizagem do ensino de história. O tema a ser utilizado para o jogo é o Massacre de Porongos com intuito de localizar o aluno surdo no tempo e espaço e, principalmente, instigar a 
construir uma perspectiva diferente daquela habitual que fora aprendido. Na proposta de rever tal tema, "[...] o jogo pode atender a distintos objetivos, desde uma sondagem ou revisão de conteúdos formais e de saberes informais, até o manuseio mais sofisticado de conceitos [...]" (MEINERZ, 2013, p. 107)

Nesse método, o papel do Professor é de suma importância, pois é ele que irá fazer o recorte a ser trabalhado através do jogo, é ele que tem o diagnóstico cultural e social de suas turmas e é, também, ele que irá planejar e provavelmente irá empregar a proposta. O professor, precisa orientar caminhos, por esse ângulo, justificamos com os autores "Nesse processo o professor faz escolhas, adapta, cria, recorta, tanto formas de jogar, quanto conteúdos para o jogo, convencido da ideia de que pesquisa e docência podem alimentar-se mutuamente". (MEINERZ, 2013, p. 105)

Assim,

\begin{abstract}
Quando tematizamos o valor do jogo no Ensino de História pensamos que não se trata apenas de criar e depois aplicar uma boa estratégia pedagógica, ou ainda aplicar algum recurso melhor do que os tantos já experimentados nas últimas décadas. Importa o fato de que, através da opção metodológica que inclui o jogo, decidimos acerca de como pensar e agir em determinados contextos que nos desafiam no Ensino de História. (MEINERZ, 2013, p. 114).
\end{abstract}

Nessa perspectiva, entendemos que o ensino de história, seja qual for a temática escolhida, tem um vasto campo de possibilidades de ensino e aprendizagem através dos jogos. Podemos problematizar, desmistificar, construir e reconstruir. Entretanto, salientamos a necessidade de inclusão, também, no mundo dos tabuleiros, por isso, a proposta de jogos no ensino de história que sejam bilíngues, para que alunos ouvintes e surdos, possam compartilhar suas dúvidas e construções que o jogo pode permitir.

\title{
3. CULTURA SURDA
}

O entendimento da cultura surda é decisivo no que se compreende como igualdade e desigualdade para com as minorias, mesmo que, por vezes, tal força não pareça pública ou resolutiva. Antes de adentrar especificamente no entendimento da cultura da comunidade surda, iremos falar sobre a percepção da cultura na contemporaneidade.

Como pondera Hall (1997, p.17):

[...] a cultura tem assumido uma função de importância sem igual no que diz respeito à estrutura e à organização da sociedade moderna tardia, aos 
processos de desenvolvimento do meio ambiente global e à disposição de seus recursos econômicos e materiais. Os meios de produção, circulação e troca cultural, em particular, têm se expandido, através das tecnologias e da revolução da informação. Uma proporção ainda maior de recursos humanos materiais e tecnológicos no mundo inteiro são direcionados diretamente para estes setores.

Para além da educação de surdos, pesquisadores dessa temática têm otimizado os debates, conduzindo as questões culturais como espaço de análise e problematização (KARNOPP; KLEIN; LUNARDI-LAZZARIN, 2011). Ou seja, o uso da cultura na contemporaneidade como aliada do campo educacional.

Em respeito às particularidades de cada cultura Skiliar (1998, p. 28) nos argumenta que:

Talvez seja fácil definir e localizar, no tempo e no espaço, um grupo de
pessoas; mas quando se trata de refletir sobre o fato de que nessa
comunidade surgem - ou podem surgir - processos culturais específicos, é
comum a rejeição à ideia da 'cultura surda', trazendo como argumento a
concepção da cultura universal, a cultura monolítica. Não me parece possível
compreender ou aceitar o conceito de cultura surda senão através de uma
leitura multicultural, ou seja, a partir de um olhar de cada cultura sem sua
própria lógica, sem sua própria historicidade, em seus próprios processos e
produções. Nesse contexto, a cultura surda não é uma imagem velada de
uma hipotética cultura ouvinte. Não é seu revés. Não é uma cultura
patológica.

Portanto, a cultura surda não é antagônica em relação à cultura do ouvinte, mas é preciso demarcar as suas diferenças, pois no entendimento do autor, a cultura surda é uma construção, a qual contém particularidades, perspectivas e na qual não existem determinismos para seu entendimento. Ela não é obstruída, ou seja, é plural. Entretanto, a cultura surda do estado do Rio Grande do Sul é diferente de um estado da região nordeste. Em destaque a essas diferenças, Karnopp, Klein, LunardiLazzarin (2011, p. 19) nos dizem o seguinte: "Esses grupo usam línguas de sinais diferentes e possuem diferentes experiências de vida; no entanto, independentemente do local onde vivem, um dos fatores que os identifica é a experiência visual". Isto posto, é de extrema importância o reconhecimento para as minorias linguísticas, em nosso caso os surdos, que aspiram fortalecer as suas origens, pois por muito tempo esses costumes foram fortemente reprimidos.

A concepção da identidade da pessoa surda também é um momento de construção diferenciada, pois parte de uma perspectiva diferente da que nós, ouvintes, estamos acostumados a perceber. O surdo vive num ambiente que, por vezes, é majoritariamente do ouvinte. Nesse local ele absorve diversas culturas - um ambiente pluricultural, mas também convive em espaços de convívio dos surdos, tais como: 
escolas de surdos, associações, grupos religiosos, associações culturais, ensino superior.

Em vista disso,

\begin{abstract}
A identidade e a cultura das pessoas surdas são complexas, já que seus membros frequentemente vivem num ambiente bilíngue e multicultural. Por um lado, as pessoas surdas fazem parte de um grupo visual, de uma comunidade surda que pode se estender além da esfera nacional, no nível mundial. É uma comunidade que atravessa fronteiras. Por outro lado, eles fazem parte de uma sociedade nacional, com uma língua de sinais própria e com culturas partilhadas com pessoas ouvintes de seu país (QUADROS; SUTTON-SPENCE, 2006, p. 111).
\end{abstract}

Diante disso, trouxemos para aprimorar a nossa proposta, o conceito da cultura surda, para entendermos e respeitarmos as diferenças em todas as suas etapas de aprendizagem. Os surdos existem em todos os tempos da história da humanidade e com eles, as línguas sinalizadas, deixando seus traços visuais; marcas acerca da diferença surda, do seu modo de enxergar, discutir e descrever o mundo (STROBEL, 2008).

\title{
4. EDUCAÇÃO DE SURDOS NO BRASIL
}

Na metade do século XIX, mais precisamente em 1857, o Império do Brasil estava sob o comando do imperador Dom Pedro II. Neste ano, o Imperador instituiu uma política educacional voltada para a comunidade surda. Cabe lembrar que antes dessa oficialização em 1857 não se tem registro da existência de uma educação específica para essa população. Segundo Strobel (2008), o interesse de Dom Pedro II com a educação de surdos surge devido ao seu genro, o Príncipe Luís Gastão de Orléans, marido da princesa Isabel, que era parcialmente surdo. No entanto, não há informações aprofundadas sobre esse fato. Todavia, independente da motivação inicial, Dom Pedro II fica marcado na história por instituir uma política educacional específica para a comunidade surda.

Dom Pedro II faz um convite a Ernest Huet, um professor surdo francês, que prontamente aceita a convocação do imperador. Huet desembarcou no Rio de Janeiro, juntamente com a sua esposa, em 1855, com o claro objetivo de fundar uma escola para surdos. Assim, em 26 de setembro de 1857 é fundado o Imperial Instituto de Surdos-Mudos, dando início ao processo de educação oficial dos surdos no Brasil. Tal escola teve o importante papel de educar e oportunizar a criação de uma Língua 
de Sinais para a comunicação entre o povo surdo, além de servir de asilo para meninos surdos de todo o país, segundo Strobel (2008).

Entretanto, nem todo o processo foi benéfico, visto que em seu início a Instituição priorizou os meninos, conforme Alves (2015, p.29), "Vale salientar, entretanto, que as meninas surdas só tiveram direito à educação no início do século XX quando surgiu o Instituto Santa Terezinha, em São Paulo". Portanto, quase cinquenta anos de atraso para que as meninas tivessem o direito à educação voltada para o povo surdo.

A oficialização da política educacional veio através da Lei ํㅜ 839, de 26 de setembro de 1857, que deu nome ao instituto que, entretanto, seria modificado pela Lei $n^{\circ}$ 3.198, de 6 de julho de 1957, para “Instituto Nacional de Educação de Surdos", apelidado de INES, tal alteração reflete o pensamento ideário contemporâneo. Sua sede permanece até hoje na capital do estado do Rio de Janeiro. Porém, apesar do avanço através da criação de uma Instituição voltada para a educação do povo surdo, o processo educacional não foi e não é fácil, conforme o relato:

Surdos foram obrigados a rejeitar sua língua natural e aprender outra língua de modalidade diferente da sua, a língua oral de seu país, e isto lhes trouxe e traz um grande prejuízo no que diz respeito ao processo de comunicação, tanto na Língua de Sinais como na própria oralização destes indivíduos. (ALVES et al, 2015, p.30)

Nesse contexto, os autores nos remetem a outra discussão acerca do método de ensino a ser utilizado na educação de surdos no Brasil: a necessidade do fortalecimento da Língua Brasileira de Sinais. Em todo o processo histórico mundial surgiram os mais variados posicionamentos acerca do uso da língua de sinais e da oralidade, boa parte das escolas estava com a oralidade enraizada em seus currículos e negando todos os aspectos socioculturais da comunidade surda.

Por isto, entendemos que D. Pedro II teve um papel fundamental na educação de surdos no Brasil, sendo seu precursor. Contudo, teve o auxílio e gerenciamento do professor Ernest Huet no comando da INES. Tal resgate trouxe novamente o debate da língua de sinais. Ademais, o estímulo e fim da negligência ajudaram no processo de oficialização da Língua Brasileira de Sinais. 


\section{CONSIDERAÇÕES FINAIS}

No presente artigo apresentamos brevemente a temática do ensino de história, da metodologia do ensino através de jogos, da cultura surda, bem como do ensino de surdos no Brasil, elementos que auxiliam na estruturação do jogo para ensino de história do Rio Grande do Sul para alunos surdos, o que será objeto de nossa dissertação de mestrado.

A temática do ensino através de jogos vêm ganhando destaque como uma estratégia positiva para viabilizar a dimensão lúdica do processo de ensinoaprendizagem muito em destaque nos dias atuais. Ganha destaque esse tema numa turma de alunos surdos onde o processo de inclusão se faz necessário e urgente.

Os jogos mobilizam e ativam um conjunto de sentimentos muito importantes para os alunos em geral e com destaque especial para os alunos surdos, nos quais as questões de colaboração e cooperação ganham relevo.

Ademais o tema escolhida para servir de referência ao jogo, qual seja, Massacre de Porongos, ocorrido durante a Guerra dos Farrapos (1835 - 1845) é de suma importância para a constituição da identidade negra do Rio Grande do Sul, tema até bem pouco invisibilizado pela historiografia.

Nesse sentido as discussões sobre uma história inclusiva, viabilizada pelo jogo bilíngue mostra-se de suma importância e estabelecem um profícuo debate com a denominada cultura surda. 


\section{REFERÊNCIAS}

BERGAMASCHI, Maria Aparecida; STHEPANOU, Maria. Ensino de História e Educação Patrimonial: memória açoriana. In: CORSETTI, Berenice; PADRÓS, Enrique; RODRIGUES, Gabriela; BERGAMASCHI, Maria Aparecida; BARROSO, Vera Lucia Maciel (Orgs.). Ensino de História: formação de professores e cotidiano escolar. Porto Alegre: Ed.EST, 2002. P.92101.

BITTENCOURT, Circe Maria Fernandes. Ensino de História: fundamentos e métodos. São Paulo: Cortez, 2005.

CARVALHO, Daniela Vallandro de. Fronteiras da Liberdade: "Experiências Negras de Recrutamento, Guerra e Escravidão" (Rio Grande de São Pedro, c.1835-1850) Tese (Doutorado) - Programa de Pós- graduação em História Social, Universidade Federal do Rio de Janeiro. Rio de Janeiro, 2013.

GASPAROTTO, Alessandra; FRAGA, Adriana; Al aram, Cauiá; FERRER, Everton de Oliveira; FRAGA, Hilda Jaqueline de; BERGAMASCHI, Maria Aparecida (Orgs.). Ensino de História no Cone Sul: patrimônio cultural, territórios e fronteiras. Porto Alegre: Evangraf, 2012.

GIACOMONI, Marcelo Paniz; PEREIRA, Nilton Mullet (Orgs). Jogos e ensino de História. Porto Alegre: Evangraf, 2013.

HALL, Stuart. A centralidade da cultura: notas sobre as revoluções culturais do nosso tempo. Educação e Realidade, Porto Alegre: UFRGS/Faced, v.22, n.2, jul./dez. 1997, p. 1546

HUIZINGA, Johan. Homo Ludens. São Paulo: Perspectiva, 2000.

KARNOPP, Lodenir Becker; KLEIN, Madalena; LUNARDI-LAZZARIN, Márcia Lise (Org.). Cultura surda na contemporaneidade: negociações, intercorrências e provocações. Canoas: Editora da ULBRA, 2011.

MONTEIRO, Ana Maria F. C. Ensino de História: entre saberes e práticas. Rio de Janeiro: Programa de Pós-graduação em Educação da PUC-RJ, 2002. Tese (Doutorado em Educação)

MORI, N., SANDER, R. História da educação de surdos no Brasil. In. SEMINÁRIO DE PESQUISA PPE., Maringá, Universidade Estadual de Maringá, 2015, p. 01-16.

MOURA, M. C., Atendimento Educacional Especializado: Estudante Surdo - Reflexões sobre a Identidade, Cultura e Comunidade. In: GIROTO, C. R. M; MARTINS, S. E. S. O; BERBERIAN, A.P (Orgs). Surdez e Educação Inclusiva. São Paulo, Cultura Acadêmica; Universitária, 2012. Cap. 5, p. 97 - 118.

PÁDUA, Elisabete M. M. de. Metodologia da pesquisa: abordagem teórico prática. 6. ed. Campinas: Papirus, 2000, $120 \mathrm{p}$.

PINSKY, Carla (org.). Novos temas nas aulas de história. São Paulo: Contexto, 2009.

QUADROS, R. M.; SUTTON-SPENCE, R. Poesia em língua de sinais. Traços da identidade surda. In: QUADROS, R. M. (Org). Estudos Surdos I: Série de Pesquisas. Petrópolis: Editora Arara Azul, 2006. p. 110-165. 
RIBEIRO, José Iran. Quando o serviço os chamava: Milicianos e Guardas-Nacionais no Rio Grande do Sul. Santa Maria: ED. da UFSM, 2005.

. "De tão longe para sustentar a honra nacional": brasileiros na Guerra dos Farrapos (1835-1850). Texto de qualificação de Doutorado em História, UFRJ, 2009.

SACKS, Oliver. Vendo Vozes: Uma jornada pelo mundo dos surdos. Rio de Janeiro: Imago Editora, 1990. ALVES, F.C.,SOUZA, J.C.T., LIMA, M. E., CASTANHO, M. Educação de Surdos em nível superior: desafios vivenciados no espaço acadêmico. IN: ALMEIDA, W.G (Org). Educação de surdos: formação, estratégia e prática docente. Ilhéus, Editus, 2015. Cap. 2, p. 27-48.

SKLIAR, Carlos. "Os Estudos Surdos em Educação: problematizando a normalidade". In: (org.). A Surdez: Um olhar sobre as diferenças. Porto Alegre: Mediação, 3. ed, 2005.

SOARES, Maria Aparecida L. A educação de surdos no Brasil. Campinas/SP: Autores Associados, 2005.

STROBEL, Karin L. História dos Surdos: Representações "Mascaradas" das Identidades Surdas. In: QUADROS, Ronice M. e PERLIN, Gladis. (Orgs.). Estudos Surdos II. Petrópolis: Arara Azul, 2007, p.18- 38.

STROBEL, Karin L. Surdos: Vestígios Culturais não Registrados na História. Florianópolis, 2008. Tese. (Doutorado em Educação) - Faculdade de Educação. Universidade Federal de Santa Catarina. 


\section{CAPÍTULO 19}

PARADIGMAS EM DISPUTAS: INTEGRAÇÃO E INCLUSÃO NA EDUCAÇÃO ESPECIAL

\section{Airton Volnei Prochnow}

Universidade Federal de Santa Maria

Perfil: http://lattes.cnpq.br/6742293774210831

E-mail: airtonprochnow@gmail.com

\section{André Haiske}

Universidade Federal de Santa Maria

Perfil: http://lattes.cnpq.br/6615631028920827

E-mail: andrehaiske@gmail.com

\section{Cleber Augusto A'costa De Lima}

Universidade Federal de Santa Maria

Perfil: http://lattes.cnpq.br/2122009098732294

E-mail: gaudiumedu@gmail.com

\section{Leonice Aparecida De Fátima Alves Pereira Mourad}

Universidade Federal de Santa Maria

Perfil: http://lattes.cnpq.br/7689442989367017

E-mail: profleomourad@gmail.com

Resumo: O presente artigo é uma revisão bibliográfica da temática da educação especial, com especial destaque aos paradigmas da integração e inclusão presentes nessa modalidade de ensino e que estão em permanente processo de disputa quando a temática é educação especial. O objetivo do capítulo é apresentar as principais reflexões sobre esse tema. A metodologia utilizada é a pesquisa bibliográfica, sendo os resultados da investigação indicativos da necessidade e esforço no sentido da incorporação da educação especial inclusiva.

Palavras-chave: Paradigma; Integração; Inclusão; Educação especial. 


\section{INTRODUÇÃO}

De acordo com o Artigo 58 da Lei 9.394/96, entende-se por educação especial:

Art. 58. Entende-se por educação especial, para os efeitos desta Lei, a modalidade de educação escolar, oferecida preferencialmente na rede regular de ensino, para educando portadores de necessidades especiais (BRASIL, 1996, Art. 58).

A deficiência contempla três dimensões: o eixo das deficiências, o das incapacidades e o das desvantagens. A missão da educação geral é auxiliar o indivíduo a montar ferramentas para si (afetivas e cognitivas), a partir das quais ele trabalhará para sua realização pessoal.

A temática da educação especial vem sendo orientada por dois paradigmas, muitas vezes tratados como equivalentes: a integração e a inclusão.

Ao longo dos séculos, as sociedades foram sofrendo uma série de transformações, quanto às atitudes dispensadas às pessoas portadoras de deficiências.

\section{DIALOGANDO SOBRE A INTEGRAÇÃO}

Desde a seleção natural para além da seleção biológica dos Espartanos - que eliminavam as crianças mal formadas ou deficientes - passando pelo conformismo piedoso do Cristianismo até a segregação e a marginalização operadas pelos "exorcistas" e "esconjuradores" da Idade Média, a perspectiva da deficiência andou sempre ligada a crenças sobrenaturais, demoníacas e supersticiosas, que culminavam em dois tipos de atitudes:

- De proteção e assistencialismo;

- De eliminação. Menosprezo e destruição.

No século XVII (1800), uma nova perspectiva educacional para o deficiente foi marcada com a experiência realizada pelo médico Francês Itard, encarregado pela academia de Paris de observar uma criança que havia sido encontrada perdida num bosque, apresentando hábitos de animal selvagem e características de subnormalidades. Nesta experiência, foi constatado que apesar de não ter alcançado uma recuperação total da criança, Itard conseguiu grandes resultados, ficando demonstrado que as pessoas deficientes eram capazes de aprender. Então, com 
Itard, tem-se pela primeira vez um trabalho de intervenção dentro de uma perspectiva educacional. Portanto, Itard. E mais tarde Seguin, seu discípulo, desenvolveram meios educacionais de atendimento a esta clientela, nascendo a pedagogia para os portadores de deficiência, e logo em seguida foram fundadas instituições para oferecer-lhes uma educação especial.

As primeiras escolas de Educação Especial foram voltadas em primeiro plano para os deficientes sensoriais, porque, à época, eram comuns os cegos com memória excepcional, que cantavam que conheciam música, que faziam uma série de maravilhas.

Em meados do século XX (1950), observa-se um movimento que tende a aceitar as pessoas portadoras de necessidades especiais e as integrá-las tanto quanto possível à sociedade.

Este movimento teve início nos países escandinavos, mais precisamente na Dinamarca, em 1959, quando foram questionadas as práticas sociais e escolares de segregação, assim como as atividades sociais em relação às pessoas com deficiência intelectual. Então, o país adotou como medida para intervir nesta situação, a promulgação do novo Ato Legal que colocava como objetivo final de todo serviço de Educação Especial, que era necessário criar condições de vida para a pessoa retardada mental semelhante, tanto quanto possível, às condições normais da sociedade em que vive.

Este foi o subsídio legal filosófico do princípio de normalização que tomou corpo a nível universal posteriormente e expandiu do âmbito restrito à pessoa portadora de deficiência mental, a todas as pessoas que apresentam necessidades especiais. A normalização visa tornar acessíveis às pessoas socialmente desvalorizadas condições e modelos de vida análogos aos que são disponíveis de um modo geral ao conjunto de pessoas de um dado meio ou sociedade.

À luz deste princípio novos conhecimentos foram surgindo e o conceito de excepcional, estático e permanente, deu lugar a uma visão mais dinâmica e humanística destes indivíduos, que passaram a ser reconhecidos, pelo menos no plano das ideias, como pessoas com direitos e deveres iguais aos demais seres humanos, precisando que lhes sejam oferecidas as mesmas condições dadas aquelas, de acesso aos bens culturais e materiais produzidos historicamente pela humanidade. 
Foram sintetizadas nos seguintes aspectos as renovações introduzidas, de caráter social, psicológico e administrativo na sociedade, com a introdução do princípio de normalização:

- Do monopólio médico para ação integrada, isto é, o que antes era feito somente pelo médico, agora é feito pelo médico em conjunto com uma equipe multiprofissional;

- Da instituição como um recurso dominante, para a instituição como parte dos recursos da comunidade;

- Do controle governamental centralizado à descentralização de decisões no sentido de que as decisões não passam mais a pertencer, unicamente ao governo, mas são dívidas com as organizações não governamentais (ONGS);

- Do sistema escolar acadêmico, exclusivo, para um sistema mais aberto e humanístico, isto é, abrem-se as portas das escolas para a possibilidade de atender também os Portadores de Necessidades Educacionais;

- Da caridade para o direito;

- Do controle e decisão dos pais aos direitos dos Portadores de Necessidades Educacionais;

- Da Associação de Pais, como proprietários e operadoras de serviços para a Associação de Pais, como orientadoras, defensoras, estimuladoras.

A integração dos Portadores de Necessidades Educacionais é uma das mais importantes consequências do princípio de normalização.

De acordo com SASSAKI:

A ideia de integração surgiu para derrubar a prática de exclusão social a que foram submetidas as pessoas deficientes por vários séculos. A exclusão ocorria em seu sentido total, ou seja, as pessoas portadoras de deficiências eram excluídas da sociedade para qualquer atividade porque antigamente elas eram consideradas inválidas, sem utilidade para a sociedade e incapazes para trabalhar, características estas atribuídas indistintamente a todos que tivessem alguma deficiência". (SASSAKI, 1997. p. 30-31).

A integração é um processo de inserção dos Portadores de Necessidades Educacionais no ensino regular e pode ser conceituada como um fenômeno complexo que vai muito além de colocar ou manter [PNE] em classes regulares. É parte do atendimento que atinge todos os aspectos do processo educacional".

O processo de integração também pode ser definido:

Como aquele que tem por objetivo incorporar física e socialmente as pessoas portadoras de deficiência, a fim de usufruírem dos bens socialmente 
produzidos, habilitando-se, oferecendo-lhes os instrumentos contemporâneos para o exercício da cidadania (MACHADO, 2007, p. 30).

Pereira aponta elementos básicos que contribuem para sistematizar e orientar atitudes educacionais no sentido de integração dos Portadores de Necessidades Educacionais no ambiente escolar.

- Integração Temporal - é a convivência dos Portadores de Necessidades Especiais com os companheiros não Portadores de Necessidades Especiais na classe regular, de preferência realizada de forma gradativa e devidamente preparada. Esta situação pressupõe a preparação da criança e do ambiente, isto é, da classe, da escola, da administração para receber o aluno.

- Integração Instrucional - condições favoráveis na sala regular que facilitem o processo ensino aprendizagem. Esta situação vai depender de três situações básicas:

- As características dos Portadores de Necessidades Especiais devem ser compatíveis com as oportunidades oferecidas às crianças que frequentam as classes comuns;

- A compatibilidade das características dos Portadores de Necessidades Especiais com as oportunidades de ensino - aprendizagem vai depender muito da habilidade e da boa vontade da professora da classe regular para modificar ou adotar novos métodos e processos de trabalho mais adequados às necessidades do aluno;

- Os serviços e recursos especiais oferecidos aos Portadores de Necessidades Especiais (sala de recursos, professor, consultor e outros) devem ser compatíveis com as necessidades do processo ensino - aprendizagem dos alunos.

- Integração Social - refere-se ao relacionamento entre a criança Portadora de Necessidades Especiais e seus companheiros não Portadores de Necessidades Especiais dentro do grupo.

Os elementos da integração, acima citados, deixam claro que neste processo, a criança Portadora de Necessidades Especiais é que deve se adaptar ao ambiente escolar e não este se adequar para atender às necessidades daquela.

Segundo PEREIRA, uma das grandes estratégias decorrente do processo de integração se relaciona com a corrente mainstreaming. Baseado em autores como Jansen, Laurence, Baker, Martin, Reynolds, Egg e Meyers, esta autora esclarece que: 
avaliações individuais. Requer aceitação e responsabilidade administrativa entre o sistema regular de ensino e educação especial.(PEREIRA,1980. p. 27).

A autora ainda complementa dizendo que "essa aproximação gradativa entre os dois tipos de atendimento define o sentido de 'cascata', de gradação, de progressão, para que o (PNE), lentamente, consiga os mecanismos de integração dentro do nível que ele puder alcançar" (PEREIRA, 1980. p. 28)

O sentido de cascata se traduz por uma estrutura que deve favorecer o ambiente o menos restritivo possível, dando oportunidade ao aluno, em todas as etapas da integração, para transitar no sistema, da classe regular ao ensino especial e vice-versa, só que o contrário dificilmente acontece.

O sentido de cascata trata-se de uma concepção de integração parcial porque prevê serviços segregados que não ensejam o alcance dos objetivos da normalização. De fato os alunos que se encontram em serviços segregados dificilmente se deslocam para os menos segregados e, raramente às classes regulares.

As hierarquias dos serviços oferecidos nesse sistema desde os menos restritivos aos mais restritivos são assim descritos por Pereira (1980):

- Aprendizagem em classes regulares;

- Classes regulares com consultores;

- Classes regulares com ensino suplementar ou tratamento;

- Classe regular mais serviços de salas de recursos;

- Classe especial em tempo parcial;

- Classe especial em tempo integral;

- Escola diurna especial;

- Escola residencial;

- Escola em hospital;

- Hospital e centros de tratamento, e outros.

A integração escolar, cuja metáfora é o sistema de cascata, é uma forma condicional de inserção em que vai depender do aluno, ou seja, do nível de sua capacidade de adaptação às opções do sistema escolar, a sua integração, seja em uma sala regular, em uma classe especial ou menos em instituições especializadas. Trata-se de uma alternativa em que tudo se mantém e nada se questiona do esquema em vigor. 
Essas características do processo de integração nos remetem ao modelo médico da deficiência, que é o plano de fundo deste processo.

Uma das razoes pelas quais as pessoas deficientes estão expostas à discriminação é o que os diferentes são frequentemente declarados doentes. Este modelo médico da deficiência nos designa o papel desamparado e passivo de pacientes, no qual somos considerados dependentes do cuidado de outras pessoas, incapazes de trabalhar, isentos dos deveres normais, levando vidas inúteis, como está evidenciado na palavra ainda comum invalido, ou seja, sem valor em latim.

SASSAKI, explica o Modelo Médico de Deficiência nos termos que "tradicionalmente, a deficiência tem sido vista como um problema do indivíduo e por isso, o próprio indivíduo teria que se adaptar à sociedade ou ele teria que ser mudado por profissionais através da reabilitação ou cura". Portanto, segundo este modelo, "a pessoa deficiente é que precisa ser curada, tratada, reabilitada, habilitada, etc. a fim de ser adequada à sociedade como ela é sem maiores modificações".

O modelo médico da deficiência tem sido responsável, em parte, pela resistência da sociedade em aceitar a necessidade de mudar suas estruturas e atitudes para incluir em seu seio as pessoas portadoras de deficiência e/ou de outras condições atípicas para que estas possam aí sim, buscar o seu desenvolvimento pessoal, social, educacional e profissional.

A integração tinha e tem o mérito de inserir o portador de necessidades especiais na sociedade, sim, mas desde que ele esteja de alguma forma capacitado a superar as barreiras físicas, programáticas e atitudinais nela existentes.

A integração nos dias de hoje, apesar de uma legislação que dá acesso aos Portadores de Necessidades Especiais, tem se constituído de um esforço unilateral tão somente de seus aliados (a família, a instituição especializada e algumas pessoas da comunidade que abracem a causa da inserção social), sendo que estes tentam torná-la mais aceitável no seio da sociedade.

A prática da integração social ocorria e ainda ocorre de três formas, a saber:

- Pela inserção pura e simples daquelas pessoas Portadoras de Necessidades Especiais que conseguiram ou conseguem, por méritos pessoais e profissionais próprios, utilizar os espaços físicos e sociais, bem como seus programas e serviços, sem nenhuma modificação por parte da sociedade, ou seja, de escola comum, da empresa comum, do clube comum; 
- Pela inserção daqueles Portadores de Necessidades Especiais que necessitavam ou necessitam alguma adaptação específica no espaço físico comum ou no procedimento da atividade comum a fim de poderem, só então, estudar, trabalhar, enfim, conviver com pessoas não Portadoras de Necessidades Educacionais;

- Pela inserção de pessoas Portadoras de Necessidades Especiais em ambientes separados dentro dos sistemas gerais. Por exemplo: classe especial numa escola comum, setor separado dentro de uma empresa comum.

Poderíamos ir mais longe ao dizer que nenhuma dessas formas de integração social satisfaz plenamente os direitos de todas as pessoas Portadoras de Necessidades Especiais, pois a integração pouco ou nada exige da sociedade em termos de modificação de atitudes, de espaços físicos, de objetos e de práticas sociais.

No modelo integrativo, a sociedade, praticamente de braços cruzados, aceita receberem os Portadores de Necessidades Especiais desde que estes sejam capazes de:

- Moldar-se aos requisitos e serviços especiais separados (classe especial, escola especial, etc.);

- Acompanhar os procedimentos tradicionais (de trabalho, escolarização, convivência social, etc.);

- Contornar os obstáculos existentes no meio físico (espaço urbano, edifícios, transportes, etc.);

- Lidar com as atitudes discriminatórias da sociedade, resultantes de estereótipos, preconceitos e estigmas, e;

- Desempenhar papéis sociais individuais (aluno, trabalhador, usuário, pai, mãe, consumidor, etc.) com autonomia, mas não necessariamente com independência.

A integração significa a inserção da pessoa Portadora de Necessidades Especiais preparadas para conviver na sociedade, esta deve se adaptar ao meio.

Neste tipo de inserção a escola oculta o seu fracasso, isolando os alunos e integrando somente os que não constituem um desafio à sua competência. 


\section{INCLUSÃO}

Em 1990, aconteceu a Conferência Mundial sobre Educação para Todos. Nesta conferência, as Nações Unidas garantiam a democratização da educação, independentemente das diferenças particulares dos alunos. Foi a partir desta conferência que o movimento da educação inclusiva começou a tomar força, para os que necessitavam de educação especial.

Em junho de 1994, em Salamanca, na Espanha, ocorreu a Conferência Mundial sobre Necessidades Educativas Especiais: Acesso e Qualidade. Nesta conferência reuniram-se mais de 300 representantes de 92 governos e 25 organizações internacionais com objetivo de:

Promover a Educação para Todos, analisando as mudanças fundamentais
de políticas necessárias para favorecer o enfoque da educação integradora,
capacitando realmente as escolas para atender todas as crianças, sobretudo
as que têm necessidades especiais (DECLARAÇÃO DE SALAMANCA,
1994).

A Conferência aprovou a Declaração de Salamanca, que expõe princípios, políticas e práticas das necessidades educativas especiais e uma linha de ação. Por este documento firma-se a urgência de ações que transformem em realidade uma educação capaz de reconhecer as diferenças, promover a aprendizagem e atender as necessidades de cada criança individualmente.

Pela importância desta declaração para o movimento de educação dos Portadores de Necessidades Especiais, destacamos a seguir alguns pontos desta Declaração que norteiam ações humanas, na organização de uma educação inclusiva.

Defende que toda criança tem direito à educação e ao acesso aos conhecimentos. E que as escolas devem acolher todas as crianças, independentemente de suas condições físicas, intelectuais, sociais, emocionais, linguísticas ou outras. Destaca o entendimento de que a expressão "necessidades educativas especiais" refere-se a todas as crianças e jovens cujas necessidades decorrem de sua capacidade ou de suas dificuldades de aprendizagem. Encerra que as escolas têm que encontrar a maneira de educar com êxito todas as crianças, inclusive as com deficiências graves.

Destaca que uma pedagogia centrada na criança deve partir do princípio de que todas as diferenças humanas são normais e, portanto, a aprendizagem deve 
ajustar-se às necessidades de cada criança, e não o contrário. E que existe a imperiosa necessidade de mudança da perspectiva social centrada na incapacidade da criança para a perspectiva centrada em seu potencial.

Apresenta a experiência de muitos países, que demonstram que a inclusão dos Portadores de Necessidades Especiais é alcançada, de uma forma mais eficaz, em escolas integradoras para todas as crianças se uma comunidade, mas que, para ter êxito, requerem um esforço comum, não só dos professores e do pessoal restante da escola, mas também dos colegas, pais, famílias e voluntários.

O princípio fundamental que reage às escolas integradoras é de que todas as crianças, sempre que possível, devem aprender juntas, independentemente de suas dificuldades e diferenças.

Destaca-se que as crianças Portadoras de Necessidades Especiais devem receber todo apoio adicional necessário para garantir uma educação eficaz. É que a permanência de crianças em escolas especiais o classes especiais, deveria ser uma exceção, só recomendável naqueles casos, nos quais se demonstre que a educação nas classes comuns não pode satisfazer as necessidades educativas ou sociais da criança, ou quando necessário para o bem estar da criança ou de outras crianças.

Indica que o planejamento oficial da educação deveria centrar-se na educação de todas as pessoas de todas as regiões do País e de qualquer condição econômica.

A criação de escolas inclusivas requer a formulação de políticas claras e decisivas de inclusão e um adequado financiamento; lançamento de programas educativos; programas de orientação e formação profissionais e os necessários serviços de apoio. Também se faz necessário, mudanças na escolarização, tais como: programa de estudos, construções, organização de escola, pedagogia, avaliação, ética escolar, atividade extra escolares, adaptação em mobiliário e etc.

Os programas de estudos devem ser flexíveis e adaptados às necessidades da criança e não o contrário, e acrescenta que a instrução deve ser relacionada com a própria experiência dos alunos e com seus interesses concretos, para que assim se sintam mais motivados.

Proclama o direito dos estabelecimentos escolares em criar procedimentos de gestão mais flexíveis, remanejar os recursos pedagógicos, diversificar as opções educativas, facilitar a mútua ajuda entre crianças, ajudar alunos que experimentem dificuldades e estabelecer relações com pais e a comunidade. Uma boa gestão 
escolar depende da participação ativa e criativa dos professores e do pessoal, da colaboração e do trabalho em equipe para atender às necessidades dos alunos.

$O$ acesso dos professores às fontes de informação e pesquisa deve ser facilitado. A preparação adequada de todos os profissionais da educação é um dos fatores-chave para propiciar a mudança para escolas inclusivas. A formação em serviço é um componente fundamental para a preparação de professores em seu ambiente de trabalho.

O êxito das escolas inclusivas depende em grande parte de uma pronta identificação, avaliação e estímulo de crianças, ainda muito pequenas, com necessidades educativas especiais. Devem ser elaborados programas de atendimento e de educação para crianças com menos de seis anos de idade ou para (re)orientá-las com vista ao seu desenvolvimento físico, intelectual e social e ao aproveitamento escolar.

Destaca que deverá ser dispensada a necessária atenção às pessoas Portadoras de Necessidades Especiais na hora de elaborar e executar os programas educativos: essas pessoas deverão ter prioridade nesses programas. Deverão ser também planejados cursos especiais que se ajustam às necessidade e condições de diferentes grupos de adultos portadores de Necessidades Especiais.

A Declaração de Salamanca ratifica que a origem do conceito de educação inclusiva são as estratégias estabelecidas, em 1990, na "Conferência Mundial sobre Educação Para Todos".

De acordo com SASSAKI, a inclusão social pode ser conceituada como:

O processo pelo qual a sociedade se adapta para poder incluir, em seus sistemas sociais gerais, pessoas com necessidades especiais e, simultaneamente estas se preparam para assumir seus papéis na sociedade. A inclusão social constitui, então, um processo bilateral no qual as pessoas, ainda excluídas, e a sociedade buscam, em parceria, equacionar problemas, decidir sobre soluções e efetivar a equiparação de oportunidades para todos. (SASSAKI, 1997. p. 43).

Os países desenvolvidos, como os EUA, o Canadá, assim como a Espanha e a Itália foram os pioneiros na implantação de classes inclusivas e de escolas inclusivas. Com algumas exceções, boa parte da literatura pertinente às práticas inclusivas na educação começa a surgir na década de 90 , basicamente relatando experiências que vem ocorrendo a partir do final dos anos 80 aos dias de hoje.

A noção de inclusão não é incompatível com a integração, porém institui a inserção de uma forma mais radical, completa e sistemática. O vocabulário de 
integração é abandonado, uma vez que o objetivo é incluir um aluno ou um grupo de alunos que já foram anteriormente excluídos; a meta primordial da inclusão é a de não deixar ninguém no exterior do ensino regular, desde o começo. As pessoas inclusivas propõem um modo de se constituir o sistema educacional que considera as necessidades de todos os alunos e que é estruturado em virtude dessas necessidades. A inclusão causa uma mudança de perspectiva educacional, pois não se limita a ajudar somente os alunos que apresentam dificuldades na escola, mas apoia a todos: professores, alunos, pessoal administrativo, para que obtenham sucesso na corrente educativa geral.

O impacto dessa concepção é considerável, porque ela supõe a abolição completa dos serviços segregados, ao longo do tempo.

O pano de fundo do processo de inclusão é o Modelo Social da Deficiência. Este Modelo nos remete a entender a questão da deficiência por outra ótica. Ele chama nossa atenção para o fato de que para incluir todas as pessoas, a sociedade deve ser modificada a partir do entendimento de que ela é que precisa ser capaz de atender às necessidades de seus membros, e não o contrário.

O Modelo Social da Deficiência focaliza os ambientes e barreiras incapacitantes da sociedade e não as pessoas deficientes. O modelo social foi formulado por pessoas com deficiência. Ele enfatiza os direitos humanos e a equiparação de oportunidades.

Pelo Modelo Social da Deficiência, os problemas da pessoa Portadora de Necessidades Especiais não estão nela tanto quanto estão na sociedade. Assim, a sociedade é chamada a ver que ver que ela cria problemas para os Portadores de Necessidades Especiais, causando-Ihes incapacidades (ou desvantagem) no desempenho de papéis sociais em virtude de:

- Seus ambientes restritivos;

- Suas políticas discriminatórias e suas atitudes preconceituosas que rejeitam a minoria e todas as formas de diferença;

- Seus discutíveis padrões de normalidade;

- Seus objetivos e outros bens inacessíveis do ponto de vista físico;

- Seus pré-requisitos atingíveis apenas pela maioria aparentemente homogênea;

- Sua quase total desinformação sobre necessidades especiais e sobre direitos das pessoas que têm essas necessidades; 
- Suas práticas discriminatórias em muitos setores da atividade humana.

Cabe, portanto, à sociedade eliminar todas as barreiras físicas, programáticas e atitudinais para que os Portadores de Necessidades Especiais possam ter acesso aos serviços, lugares, informações e bens necessários ao seu desenvolvimento pessoal, social, educacional e profissional.

Conforme SASSAKI, citado anteriormente:

A prática da inclusão social repousa em princípios até então considerados incomuns, tais como: a aceitação das diferenças individuais, a valorização de cada pessoa, a convivência dentro da diversidade humana, a aprendizagem através da cooperação. (1997. p. 4).

Portanto, a inclusão social é um processo que contribui para a construção de um novo tipo de sociedade através de pequenas e grandes transformações, nos ambientes físicos (espaços internos e externos, equipamentos, aparelhos e utensílios, mobiliário e meios de transporte) e na mentalidade de todas as pessoas, inclusive o Portador de Necessidades Especiais.

À luz deste processo, as instituições são desafiadas a serem capazes de criar programas e serviços internamente e/ou de buscá-los em entidades comuns da comunidade para melhor atender os Portadores de Necessidades Especiais.

Mas, ainda é preciso esclarecer que estamos vivendo a fase de transição entre a integração e a inclusão. É inevitável que os dois termos sejam falados e escritos com diversos sentidos por diferentes pessoas, a saber:

- Algumas pessoas utilizam as palavras integração e inclusão, já em conformidade com a moderna terminologia da inclusão social, ou seja, com sentidos distintos - a integração significando inserção das pessoas deficiente preparada para conviver na sociedade e a inclusão significando modificação da sociedade como pré - requisito para a pessoa com necessidades especiais buscar seu desenvolvimento e exercer a cidadania;

- Outras pessoas utilizam os termos integração e integração total ou plena da seguinte forma: o primeiro termo integração com sentido de inserção da pessoa deficiente preparada para conviver na sociedade e o segundo termo (integração total) correspondendo ao moderno conceito de inclusão sem, no entanto, usarem a palavra inclusão. Este é o caso da maioria dos trabalhos acadêmicos, científicos ou técnicos publicados até aproximadamente 1994, ano em que saiu o primeiro documento 
internacional que aborda extensamente o conceito de inclusão - a Declaração de Salamanca.

- Ainda outras pessoas utilizam apenas a palavra integração, tanto num sentido como noutro (de integração e de inclusão), nunca usando termos "inclusão" e "integração total (ou plena)".

- Há também pessoas que utilizam indistintamente os termos integração, integração total (ou plena) e inclusão, ou seja, como se fossem sinônimos, todos significando uma única coisa - inserção da pessoa deficiente preparada para conviver na sociedade.

Portanto a inclusão é a inserção da pessoa PNE no ambiente escolar e social, tendo estes que se adequarem às necessidades daquele.

\section{CONSIDERAÇÕES FINAIS}

A revelação do modelo médico da deficiência e do modelo social da deficiência, evidenciados no estudo contribui sobremaneira para facilitar o entendimento a respeito dos conceitos de integração e inclusão. Portanto, torna-se relevante descrevê-los sinteticamente neste momento.

Pelo modelo médico da deficiência o PNE é considerado doente e por isso, precisa ser curado, reabilitado, habilitado, a fim de ser adequado à sociedade como ela é sem maiores modificações.

Pelo modelo social da deficiência a sociedade é chamada a ver que acaba criando problemas para os PNE, causando-Ihes incapacidades (ou desvantagens) no desempenho de papéis sociais. Este modelo focaliza os ambientes e barreiras incapacitantes da sociedade e não as pessoas deficientes. Conclama a sociedade a eliminar barreiras físicas, programáticas e atitudinais para que o PNE possa ter acesso aos serviços, lugares, informações e bens necessários ao seu desenvolvimento pessoal, social, educacional e profissional.

Neste sentido, o modelo médico da deficiência constitui-se, filosoficamente, pano de fundo do processo de integração, e o modelo social da deficiência pano de fundo do processo de inclusão.

A declaração de Salamanca de princípios, políticas e práticas dos PNE, corroborou de forma significativa, para um melhor entendimento do processo de 
inclusão, uma vez que ela é um instrumento importante de orientação político Educacional para os profissionais que atuam na educação.

Conforme foi evidenciado por Sassaki (1997) a sociedade vive uma fase de transição entre a integração e a inclusão, os dois termos são falados e escritos com diversos sentidos: algumas pessoas estão usando um e outro como sinônimo, outras utilizam os termos indistintamente; já outras utilizam a palavra integração correspondendo ao conceito de inclusão. Para que o processo de inclusão seja posto em prática, visto que este parece ser o que mais se aproxima do ideal, é preciso que ocorram mudanças.

Em consonância com Pereira (1980), entendemos ser preciso para a Educação do PNE, que:

- As escolas se adaptem, de forma a eliminar barreiras físicas e atitudinais que possam impedir o acesso do PNE em seu interior e modificar seus métodos, quando se fizer necessário, para que seus serviços sejam oferecidos a todas as crianças;

- Os pais participem de forma efetiva do processo educacional da criança, junto com a escola acompanhando e continuando o ensino no lar;

- As autoridades governamentais assumam compromisso permanente, a fim de ajudarem técnica e financeiramente, para garantir um bom atendimento do PNE.

Haja ênfase na importância da formação do educador, como ponto crucial à efetivação do processo de educação inclusiva.

Para que essas mudanças aconteçam, é preciso haver um esforço de todos os envolvidos: escola, família, comunidade, sociedade, pois somente com a participação de todos, a educação do PNE, poderá ocorrer a contento. 


\section{REFERÊNCIAS}

DECLARAÇÃO DE SALAMANCA e Linha de Ação Sobre Necessidades Educativas Especiais. Brasília: Corde, 1994.

LEPOT-FROMENT Cristiane (Org). Educação Especializada: Pesquisa e Indicações para a Ação. Bauru: EDUSC, 1999.

MACHADO, Rosângela. A (dês)integração do Aluno Portador de Deficiência na Rede Regular de Ensino de Florianópolis, 1998. Monografia (Especialização em Atividade Motora Adaptada). Centro de Desportos, Universidade Federal de Santa Catarina.

MACHADO, L. M.; LABEGALINI, A. C. F. B. A educação inclusiva na legislação de ensino. Marília: Edições M3T Tecnologia e Educação, 2007

MAZZOTTA, Marcos José Silveira. Educação Especial no Brasil: História e Políticas Públicas. São Paulo: Cortez, 1996.

PEREIRA, Olívia, et al. Educação Especial: Atuais Desafios. Rio de Janeiro: Interamericana, 1980.

SASSAKI, Romeu Kazumi. Inclusão, Construindo Uma Sociedade Para Todos. Rio de Janeiro: WVA, 1997.

VIEIRA, Leociléa Aparecida. Projetos e pesquisa e monografia: o que é? Como se faz?: Normas da ABNT. Curitiba: Ed. do Autor, 2002. 


\section{CAPÍTULO 20}

PSICOPEDAGOGIA E DISTÚRBIOS DA LEITURA E ESCRITA: DISLEXIA, DISCALCULIA, DISGRAFIA, DISORTOGRAFIA

\section{Airton Volnei Prochnow}

Universidade Federal de Santa Maria

Perfil: http://lattes.cnpq.br/6742293774210831

E-mail: airtonprochnow@gmail.com

\section{André Haiske}

Universidade Federal de Santa Maria

Perfil: http://lattes.cnpq.br/6615631028920827

E-mail: andrehaiske@gmail.com

\section{Isadora Luiza Francisca Alves Flores}

Universidade Estadual do Oeste do Paraná

Perfil: http://lattes.cnpq.br/6853840335708600

E-mail: isadora94flores@gmail.com

\section{Leonice Aparecida De Fátima Alves Pereira Mourad}

Universidade Federal de Santa Maria

Perfil: http://lattes.cnpq.br/7689442989367017

E-mail: profleomourad@gmail.com

Resumo: Este artigo é uma revisão bibliográfica de distúrbios de leitura e escrita, tais como: dislexia, disgrafia, discalculia e disortografia e seu tratamento pela psicopedagogia, apresentando alguns aspectos destes distúrbios bastante comuns no espaço escolar. O objetivo deste capítulo é apresentar algumas reflexões sobre o tema. A metodologia utilizada é a pesquisa bibliográfica, sendo os resultados da investigação indicativos da necessidade e esforço, no sentido de atentar para os sintomas desses distúrbios, bem como de encontrar tratamento profissional adequado para pessoas com tais distúrbios pois os mesmo provocam níveis de exclusão social e emocional bastante severos.

Palavras-chave: Psicopedagogia; Distúrbios; Leitura; Escrita. 


\section{INTRODUÇÃO}

O presente texto apresenta brevemente a psicopedagogia enquanto área de conhecimento enfatizando a sua constituição plural para na sequência apresentar quatro distúrbios de leitura e escrita bastante comuns no espaço escolar e que são tratados pelo psicopedagogo. Trata-se de um artigo de revisão cujo objetivo é apresentar o campo de conhecimento e os distúrbios com suas tipificações. $\mathrm{O}$ artigo está organizado em três sessões: apontamentos sobre psicopedagogia, dificuldades de aprendizagem, distúrbios da leitura e da escrita e dislexia, discalculia, disgrafia e disortografia.

\section{APONTAMENTOS SOBRE PSICOPEDAGOGIA}

A psicopedagogia é uma área de conhecimento interdisciplinar cujo propósito é a maior compreensão do processo de aprendizagem sendo na sua origem articulação entre Medicina, Psicologia, Psicanálise e Pedagogia, na solução dos problemas de comportamento e de aprendizagem, tendo pois no seu início um caráter médico-pedagógico (BOSSA, 2000, p. 37).

Em razão da complexidade dos problemas de aprendizagem, a Psicopedagogia se configura com um caráter multidisciplinar, que demanda conhecimento em diversas outras áreas, além da psicologia e da pedagogia, com especial destaque a:

- Linguística, para explicar como se dá o desenvolvimento da linguagem humana e sobre os processos de aquisição da linguagem oral e escrita.

- Conhecimentos sobre o desenvolvimento neurológico, sobre suas disfunções que acabam dificultando a aprendizagem;

- Conhecimentos filosóficos e sociológicos, que nos oferecem o entendimento sobre a visão do homem, seus relacionamentos a cada momento histórico e sua correspondente concepção de aprendizagem (FERREIRA, 2006).

A psicopedagogia é um campo do conhecimento que se propõe a integrar, de modo coerente, conhecimentos e princípios de diferentes ciências humanas com a meta de adquirir uma ampla compreensão sobre os variados processos inerentes ao aprendizado humano (BEAUCLAIR, 2004).

A psicopedagogia nasceu da necessidade de melhor compreensão do processo de aprendizagem e se tornou uma área de estudo específica que busca 
conhecimento em outros campos e cria seu próprio objeto de estudo, ocupando-se do processo de aprendizagem humana, seus padrões de desenvolvimento e a influência do meio nesse processo (FERREIRA, 2006).

Ferreira (2006) assevera que há algum tempo, a falta de clareza a respeito dos problemas de aprendizagem, fazia com que os alunos com dificuldades fossem encaminhados para profissionais de diversas áreas de atuação, sem uma resolução eficiente dos problemas.

Ainda sobre a constituição do campo é preciso mencionar que a psicopedagogia tem sofrido influências de diversas correntes teóricas ao longo de sua existência.

\begin{abstract}
Na década de 1950/1960, quando da sua constituição, a mesma tinha uma visão médica, enfocando o problema que acontecia com o sujeito com relação à aprendizagem. Esta visão partia de uma abordagem neuropsicológica, uma vez que existindo um problema de aprendizagem, este deveria ser sanado investigando-se qual dificuldade apresentada pelo sujeito, que ocasionava o fracasso escolar (SCHMID, 2006).
\end{abstract}

Na década de 1960/1970, estávamos diante da hegemonia de uma visão behaviorista, ou seja, parou de abordar as falhas e começou a trabalhar os condicionamentos, avaliando o desempenho do sujeito.

Na década de 1980, seu estudo começa a possuir uma visão social, dialética devido à influência da teoria de Vygotsky que considera relevante o meio social do sujeito para sua aprendizagem. Neste momento, surge o profissional psicopedagogo/educador interdisciplinar, que dá importância ao processo de aprendizagem. Começa-se a pensar porque este sujeito fracassa e não mais como ele fracassa, levando-se em conta o meio social do sujeito.

O Código de Ética do Psicopedagogo, disponibilizado pela refere no seu artigo primeiro sobre o que é a psicopedagogia, asseverando que:

A Psicopedagogia é um campo de conhecimento e ação interdisciplinar em Educação e Saúde com diferentes sujeitos e sistemas, quer sejam pessoas, grupos, instituições e comunidades. Ocupa-se do processo de aprendizagem considerando os sujeitos e sistemas, a família, a escola, a sociedade e o contexto social, histórico e cultural. Utiliza instrumentos e procedimentos próprios, fundamentados em referenciais teóricos distintos, que convergem para o entendimento dos sujeitos e sistemas que aprendem e sua forma de aprender ${ }^{2}\left(\right.$ Art $\left.1^{\circ}\right)$.

No artigo segundo encontramos menção ao seu caráter inter e transdisciplinar, como segue:

\footnotetext{
${ }^{2}$ Código De Ética Do Psicopedagogo
} 
A Psicopedagogia é de natureza inter e transdisciplinar, utiliza-se de recursos próprios para a compreensão do processo de aprendizagem dos sujeitos e sistemas com vistas à intervenção ${ }^{3}\left(\right.$ Art. $\left.2^{\circ}\right)$.

Quando da leitura dos objetivos da psicopedagogia aparece claramente a temática da inclusão escolar;

A atividade psicopedagógica tem como objetivos:

- propor ações frente aos processos de aprendizagem e suas dificuldades;

- contribuir para os processos de inclusão escolar e social;

- realizar pesquisas científicas no campo da Psicopedagogia;

- mediar as relações interpessoais nos processos de aprendizagem com vistas à prevenção de dificuldades e/ou à resolução de conflitos. ${ }^{4}$ (Art. $3^{\circ}$ ).

Em conformidade com o Art. 4ํㅜㄹ no que tange a formação do psicopedagogo a mesma ocorre em curso de graduação e/ou em curso de pós-graduação em Psicopedagogia, ministrados em instituições de educação superior devidamente reconhecidas e autorizadas por órgãos competentes ${ }^{5}$.

\subsection{Dificuldades de Aprendizagem}

A questão da dificuldade de aprendizagem é um fenômeno mais frequente do que possamos imaginar no cenário escolar. São inúmeras as razões para esse contexto, causas sociais, psíquicas, culturais, pedagógicas, etc. O que é inegável são os impactos psicossociais, psicológicos e sociais, que envolvem questões escolares e de comportamento na vida de um indivíduo.

\footnotetext{
${ }^{3}$ Código De Ética Do Psicopedagogo

${ }^{4}$ Código De Ética Do Psicopedagogo

${ }^{5}$ Art. 5o Código De Ética Do Psicopedagogo
} 
Nutti (2002) ao definir e distinguir distúrbio, transtorno e dificuldades e/ou problemas de aprendizagem afirma que a temática é uma das mais inquietantes problemáticas para aqueles que atuam no diagnóstico, prevenção e reabilitação do processo de aprendizagem, pois envolve uma vasta literatura fundamentada em concepções nem sempre coincidentes ou convergentes.

Etimológicamente, a palavra distúrbio compõe-se do radical turbare e do prefixo dis. O radical turbare significa "alteração violenta na ordem natural" e pode ser identificado também nas palavras turvo, turbilhão, perturbar e conturbar. O prefixo dis tem como significado "alteração com sentido anormal, patológico" e possui valor negativo. O prefixo dis é muito utilizado na terminologia médica (por exemplo: distensão, distrofia). Em síntese, do ponto de vista etimológico, a palavra distúrbio pode ser traduzida como "anormalidade patológica por alteração violenta na ordem natural" (COLLARES E MOYSES, 1992).

Portanto, um distúrbio de aprendizagem obrigatoriamente remete a um problema ou a uma doença que acomete o aluno em nível individual e orgânico (NUTTI, 2002).

De acordo com Carvalho (2009) na aprendizagem escolar, existem os seguintes elementos centrais, para que o desenvolvimento escolar ocorra com sucesso: o aluno, o professor e a situação de aprendizagem.

O processo de aprendizagem demanda uma articulação entre a dimensão cognitiva, afetiva e a ação e, nos indivíduos que não apresentam dificuldades, esta articulação processa-se sem problemas, garantindo a aprendizagem.

Já aqueles que por algum motivo apresentam dificuldades, este processo parece caótico, desorganizado, o que provoca desconforto e tensão diante das situações de aprendizagem.

A literatura especializada demonstra que uma dificuldade de aprendizagem é um transtorno permanente que afeta a maneira pela qual, os indivíduos com inteligência normal e acima da média selecionam, retém e expressam informações. As informações podem ficar desordenadas conforme fazem as sinapses.

As dificuldades de aprendizagem devem ser consideradas como uma causa possível se uma criança tem dificuldade em um ou mais dos seguintes aspectos: 
- Pensar claramente;

- Escrever legivelmente;

- Soletrar com exatidão;

- Aprender a ler;

- Aprender a calcular;

- Copiar formas;

- Recordar fatos;

- Seguir instruções;

- Colocar coisas em sequência.

Esse contexto acaba por provocar na maioria das vezes, confusão, impulsividade, hiperatividade, desorientação, podendo gerar frustração, rebeldia, retraimento, agressividade ou depressão.

Para Paín (1992) os Distúrbios, Dificuldades e Problemas de Aprendizagem, sem dúvida, são os mais inter e multidisciplinar dos temas, porque requer o envolvimento dos vários aspectos: psicológicos, orgânicos e sociais, e mescla, em seu atendimento, os conceitos das diversas áreas: Psicologia, Fonoaudiologia, Psicomotricidade e Sociologia, sendo uma área importante de atuação do psicopedagogo.

São inúmeras as classificações para os distúrbios de aprendizagem. Basicamente temos dificuldades nos planos da leitura, da escrita e da matemática. Outras mais globais seriam de origem afetiva. Neste artigo privilegiamos os distúrbios de aprendizagem de leitura, escrita e matemática.

\section{DISTÚRBIOS DA LEITURA E DA ESCRITA}

É através da comunicação que os indivíduos interagem socialmente, sendo a mesma um elemento essencial para a socialização e integração humana. Diante disso, distúrbios da comunicação causam impacto severo sobre a vida social das pessoas e sobre o sucesso escolar.

Crianças com atraso no desenvolvimento da linguagem irão apresentar, na idade escolar, importantes e persistentes anormalidades neuropsicológicas, entre elas os transtornos específicos de aprendizagem 
Linguagem é o sistema simbólico usado para representar os significados em uma cultura, abrangendo seis componentes: fonologia (sons da língua), prosódia (entonação), sintaxe (organização das palavras na frase), morfologia (formação e classificação das palavras), semântica (vocabulário) e pragmática (uso da linguagem).

A linguagem significa trocar informações (receber e transmitir) de forma efetiva, enquanto que a fala refere-se basicamente à maneira de articular os sons na palavra (incluindo a produção vocal e a fluência).

Em razão do uso da leitura e da escrita serem habilidades sociais e culturais fundamentais em nossos dias, é necessário aos educadores conhecerem alguns distúrbios específicos da linguagem.

\subsection{Dislexia}

Dislexia é um transtorno de aprendizagem que, segundo especialistas, é um defeito no cérebro, afetando a memória visual, dificultando assim, o aprendizado e reconhecimento das palavras e letras. A dislexia tem sido um dos assuntos mais estudados nos últimos anos, devido à dificuldade de diagnóstico e enfrentamento.

LERNER (2003), ao tratar da etimologia da palavra afirma que a mesma é constituída pelos radicais "dis" que significa dificuldade ou distúrbio, e "lexia", que significa leitura no latim e linguagem no grego, ou seja, o termo dislexia refere-se a dificuldades na leitura ou a dificuldades na linguagem, porém, a ideia de que se relaciona a um distúrbio na leitura parece ser aquela que é mais corriqueira.

TELES (2009) acrescenta que "a dislexia é caracterizada por dificuldades na correção e/ou fluência na leitura de palavras e por baixa competência leitora e ortográfica. Estas dificuldades resultam tipicamente de um déficit no componente fonológico da linguagem que é frequentemente imprevisto em relação a outras capacidades cognitivas e às condições educativas. Secundariamente podem surgir dificuldades de compreensão leitora, experiência de leitura reduzida que podem impedir o desenvolvimento do vocabulário e dos conhecimentos gerais". (ASSOCIAÇÃO INTERNACIONAL DE DISLEXIA, 2003 apud TELES, 2009).

A dislexia afeta todos os grupos sociais, caracterizando-se por dificuldade na precisão de reconhecimento das palavras, decodificação de mensagens e soletração, 
reduzindo a capacidade de compreensão e leitura, resultante no déficit de processamento fonológico.

O déficit de processamento fonológico está associado à consciência fonológica que é a percepção de que as palavras são construídas por diversos sons. Tal conceito diz respeito tanto à compreensão de que a fala pode ser segmentada quanto à habilidade de manipular essas unidades.

O diagnóstico da dislexia pode ser identificado através:

- Da leitura: dificuldades em ler palavras isoladas e soletrar, leitura incorreta, lenta requerendo muito esforço.

- Compreensão: O disléxico tem dificuldade de entender o que é lido e compreender a sequência e a relações das palavras.

- Ortografia: Dificuldade nas palavras, omitindo letras e substituindo vogais e letras de forma incorreta.

- Escrita: Erros gramáticos, dificuldade de expressar escrita e ideias, pontuação e falta de organização dos parágrafos.

- Baixo desempenho: dificuldades em exercer atividades propostas, testes e avaliações, habilidades abaixo do esperado.

A dislexia pode ser identificada em diferentes tipos, a saber:

- Dislexia adquirida: Acontece no leitor competente, que perde sua capacidade e habilidade de leitura, devido a uma lesão cerebral.

- Dislexia Evolutiva ou de Desenvolvimento: Se revela no indivíduo no início da aprendizagem, devido às dificuldades apresentadas na leitura.

- Dislexia Disfonética: Dificuldade de integração da letra e do som, onde a palavra lida não assimilada com a soletração, substituição da semântica é a mais frequente.

- Dislexia Diseidética: Dificuldade em decifrar os sons e letras, altera a ordens da palavra, grafemas e fonemas, omissões e acréscimos de consoantes e vogais na palavra.

- Dislexia visual: Dificuldade na visualização do fonema, na coordenação motora, percepção visual comprometida. 
- Dislexia auditiva: Deficiência na memória auditiva, impossibilitando a audição correta e cognitiva do fonema.

- Dislexia mista: Combinação de uma ou mais tipos de dislexia.

Compreender o distúrbio de aprendizagem é conceber que os mesmos podem ser multifatoriais, assim como seus efeitos. A dislexia apresenta problemas significativos na fase inicial de alfabetização, podendo comprometer os conhecimentos matemáticos.

\subsection{Discalculia}

A discalculia é uma deficiência na aprendizagem, caracterizada pela dificuldades em entender conceitos, números, símbolos e funções matemáticas. A discalculia compromete o desenvolvimento matemático, afetando a habilidade de fazer cálculos e funções operacionais. Esse distúrbio de aprendizagem atrapalha o indivíduo não somente em sua vida escolar e no cotidiano.

Sua manifestação pode se dar em combinações diferentes, dentro de outros transtornos de aprendizagem, como déficit de atenção, hiperatividade e dislexia.

Tipos de Discalculia e suas dificuldades:

- Discalculia verbal: dificuldade na enumeração e nomeação de números, símbolos ou termos matemáticos.

- Discalculia practognóstica: Dificuldade na comparação, enumeração e manipulação de objetos reais e imagens.

- Discalculia léxica: Dificuldade na leitura de símbolos matemáticos.

- Discalculia gráfica: dificuldade em escrever símbolos matemáticos.

- Discalculia ideognóstica: Dificuldades em compreender a matemática e seus conceitos e em realizar operações mentais.

- Discalculia operacional: Dificuldade em reproduzir cálculos numéricos e operações.

A discalculia como uma dificuldade de aprendizado que envolve especificamente a área matemática, pode acabar fazendo com que muitos indivíduos 
apresentem excelente desempenho em outras disciplinas, mas apresentar dificuldade de aprendizado matemático.

Dislexia e discalculia estão associadas a algumas falhas e alterações no cérebro de origem neuro-biológicas, que causam a desorganização espacial, que interferem na organização de números matemáticos, assimilação de gráficos e espaço, reconhecimento das letras, formas e símbolos, ocasionando dificuldade na leitura, escrita e cálculos matemáticos.

\subsection{Disgrafia}

É a dificuldade em passar para a escrita o estímulo visual ou a percepção da “coisa”. Caracteriza-se pelo lento traçado das letras, em geral são ilegíveis.

Existem vários níveis da disgrafia, desde a incapacidade de segurar um lápis e traçar uma linha, até a apresentada por crianças que são capazes de fazer desenhos simples, mas não cópias de palavras do quadro.

As principais características das crianças disgráficas são:

- Apresentação desordenada do texto;

- Margens mal feitas ou inexistentes;

- Espaço irregular entre palavras, linhas e entrelinhas;

- Traçado de má qualidade;

- Distorção de formas de letra e,

- Separação inadequada de letras.

\subsection{Disortografia}

Caracteriza-se pela incapacidade de transcrever corretamente a linguagem oral, havendo trocas ortográficas e confusão de letras. Essa dificuldade não implica na diminuição da qualidade do traçado das letras.

As trocas ortográficas são normais nas séries iniciais, porque a relação entre a palavra impressa e os sons ainda não estão totalmente dominadas. As principais características das crianças que apresentam disortografia costumam ser: 
- Confusão de letra (consoantes surdas por sonoras: $f / v ; p / b ; c h / j)$;

- Confusão de sílabas com tonicidades semelhantes;

- Confusão de letras simétricas (b/d; q/p) e semelhantes (e/a; b/h;f/t).

\section{CONSIDERAÇÕES FINAIS}

O princípio fundamental das escolas inclusivas consiste em todos os alunos aprenderem juntos, sempre que possível, independentemente das dificuldades e das diferenças que apresentam. Estas escolas devem reconhecer e satisfazer as necessidades diversas dos seus alunos, adaptando-se aos vários estilos e ritmos de aprendizagem, de modo a garantir um bom nível de educação para todos através de currículos adequados.

Aprender algo novo é desafiador, principalmente para o disléxico, por isso, o uso de estratégias específicas tende a motivar o ensino para romper as barreiras de dificuldades existentes durante todo o caminho do saber.

Quando os efeitos positivos da inclusão são contrastados com os efeitos negativos da exclusão, os benefícios das escolas inclusivas tornam-se mais evidentes.

Sem dúvida, a razão mais importante para o ensino inclusivo é o valor social da igualdade. Ensinamos os alunos através do exemplo de que, apesar das diferenças, todos nós temos direitos iguais. 


\section{REFERÊNCIAS}

BEAUCLAIR, João. Psicopedagogia - trabalhando competências, criando habilidades. Rio de Janeiro: WAK Editora, 2004.

BOSSA, Nádia Ap. A Psicopedagogia no Brasil: contribuições a partir da prática. Porto Alegre: Artes Médicas, 2000.

CARVALHO, Maria Salete C. Dificuldades de aprendizagem (2009). Disponível em: http://www.artigonal.com/educacao-artigos/ dificuldades-de-aprendizagem-1228106.html. Acesso em: 3 fev. 2021.

COLLARES, C. A. L. e MOYSÉS, M. A. A. A.História não Contada dos Distúrbios de Aprendizagem. Cadernos CEDES n. 28, Campinas: Papirus, 1993, P.31-48.

FERREIRA, Renata Tereza da Silva. A importância da psicopedagogia no ensino fundamental - 1a A 4⿳亠丷厂 SÉRIES. Disponível em: http://www.psicopedagogiaonline.com.br. Acesso em: 03.mar. 2021.

LERNER, J. W. Learning Disabilities: Theories, Diagnosis, and Teaching

Strategies. Boston: Houghton Mifflin Company. Morais, J. A Arte de Ler - Psicologia Cognitiva da Leitura. Lisboa: Edições Cosmos. 1997

MENDES,Mônica M. (org.) A práxis psicopedagógica brasileira. São Paulo: ABPp, 1994.

NUTTI, Juliana Zantut. Distúrbios, transtornos, dificuldades e problemas de aprendizagem. Disponível em: http://www.psicopedagogia.com.br/artigos/artigo.asp?entrID=339. Acesso em: 02 fev. 2021.

PAíN, Sara. Diagnóstico e Tratamento dos problemas de aprendizagem. Porto Alegre: Artes Médicas, 2003.

SCOZ, Beatriz J.L. (org.) Psicopedagogia: o caráter interdisciplinar na formação e atuação profissional. Porto Alegre: Artes Médicas, 1987.

SCOZ, Beatriz J.L. (org.) Psicopedagogia: contextualização, formação e atuação profissional. Porto Alegre: Artes Médicas, 1992.

SCHMID, Márcia H. C. Psicopedagogia e educação de jovens e adultos. Universidade Federal Fluminense. Disponível em: http://www.cereja.org.br/pdf/20050331_Marcia.pdf. Acesso em: 02 jan. 2021.

TELES, P. (2009). Dislexia: Método Fonomímico - Abecedário e Silabário. Lisboa: Distema. 
Agência Brasileira ISBN

ISBN: 978-65-995551-1-4 